
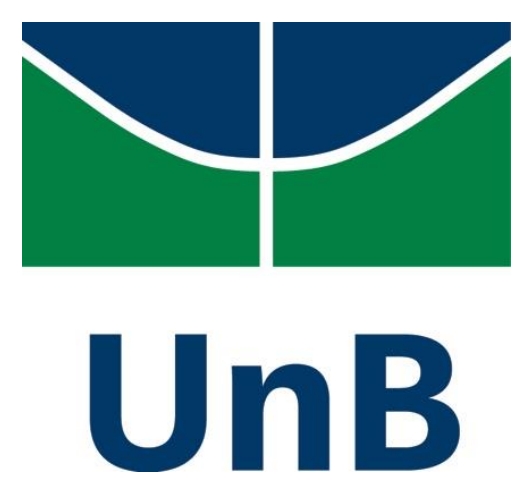

UNIVERSIDADE DE BRASÍLIA

INSTITUTO DE ARTES/DEPARTAMENTO DE MÚSICA

PROGRAMA DE PÓS-GRADUAÇÃO MÚSICA EM CONTEXTO

A BARQUINHA DE MESTRE DANIEL: ETNOGRAFIA DA MÚSICA DE UMA TRADIÇÃO RELIGIOSA AYAHUASQUEIRA AMAZÔNICA

DANIEL CASTRO MONTOYA FLORES

BRASÍLIA

2020 


\section{A BARQUINHA DE MESTRE DANIEL: ETNOGRAFIA DA MÚSICA DE UMA TRADIÇÃO RELIGIOSA AYAHUASQUEIRA AMAZÔNICA}

Dissertação apresentada ao Programa de Pós-Graduação em Música do Departamento de Música da Universidade de Brasília, como requisito parcial para obtenção do grau de Mestre em Música.

Área de concentração: Música em Contexto. Linha de pesquisa: Musicologia.

Orientador: Prof. Dr. Sérgio Nogueira Mendes

\section{BRASÍLIA}

2020 


\section{Universidade de Brasília}

Departamento de Música

UnB Programa de Pós-Graduação Música em Contexto

Dissertação intitulada A Barquinha de Mestre Daniel: etnografia da música de uma tradição religiosa ayahuasqueira de autoria de Daniel Castro Montoya Flores. Aprovada pela banca examinadora constituída pelos seguintes professores:

Prof. Dr. Sérgio Nogueira Mendes

Prof. Dr. Mário Lima Brasil

Prof. Dr. Hugo Leonardo Ribeiro 
À Dona Alice Maria (minha mamãe amada) e a todos aqueles que um dia, como ela, acreditaram em mim e me estenderam uma mão amiga. 


\section{AGRADECIMENTOS}

Agradeço primeiramente, a Deus, o Pai Criador, o Filho Salvador e o Espírito Santo Inspirador.

À Nossa Senhora do Perpétuo Socorro, mãe caridosa que me alcançou esta graça, quando a ela recorri, abrindo todas as portas para que eu pudesse chegar até aqui. Melhor do que todas as experiências que vivi neste período do Mestrado (que foram muitas), foi a oportunidade de reconhecer a presença dessa mãe poderosa em minha vida.

À madrinha Chica Gabriel, padrinho Chico Gabriel (in memorian), e todos os irmãos da missão de Mestre Daniel.

Aos meus pais e minhas irmãs, a primeira família. A minha esposa, meus filhos, a família da minha esposa, a minha segunda família que tanto me ajudaram neste período.

Aos queridos irmãos amigos Marcelo e Selene, compadre Augusto e toda a comunidade da filial do Centro Espírita Obras de Caridade Príncipe Espadarte em Brasília, por toda ajuda, consideração e amizade. Eterna gratidão!!

Aos professores da Universidade de Brasília, os quais convivi no período do mestrado. Em especial a professora Dra. Beatriz Magalhães Castro e o professor Dr. Sergio Nogueira Mendes que me acolheram e orientaram os meus passos no decorrer deste trabalho.

Por fim sou grato a todos as pessoas que me ajudaram de uma forma ou de outra nesta empreitada. Foram muitas mãos amigas que recebi nesta caminhada e sou grato a todos. Peço a Deus para que possa retribuir a caridade e generosidade de todos. 


\section{ÍNDICE DE FOTOS}

Foto 1 - Hino “Eu tinha um Barquinho”. (p.19)

Foto 2 - Daniel Pereira de Mattos (Mestre Daniel). (p.23)

Foto 3 - Raimundo Irineu Serra (Mestre Irineu). (p. 24)

Foto 4 - Mestre Irineu reunido com a irmandade. (p. 25)

Foto 5 - Mestre Antônio Geraldo reunido com a irmandade (CECOCJFL). (p. 29)

Foto 6 - Fachada do templo (CECOCJFL). (p. 30)

Foto 7 - Fachada do templo (CELAC). (p. 32)

Foto 8 - Mestre Antônio Geraldo no CEDPM. (p. 33)

Foto 9 - Fachada do templo (CEDPM). (p. 33)

Foto 10 - Padrinho rezando em criança (CEOCPE). (p. 35)

Foto 11 - "Casinha do Pai Vicentino" (CEOCPE). (p. 35)

Foto 12 - Fachada do templo (CEOCPE). (p. 36)

Foto 13 - Procissão da Romaria (CEOCPE). (p. 45)

Foto 14 - Gongá (CEOCPE). (p. 47)

Foto 15 - Feitio de Daime (CEOCPE). (p. 53)

Foto 16 - Um dia de Festa no CEOCPE. (p. 57)

Foto 17 - Valsa Lydia. (p. 67)

Foto 18 - Valsa Alvorada de Amor. (p. 68)

Foto 19 - Contracapa do CD “Alvora de Amor”. (p. 68)

Foto 20 - Cantores em performance musical (CECOCJFL). (p. 80) 
Foto 21 - Músicos em performance musical (CECOCJFL). (p.80)

Foto 22 - Músicos em performance musical (CECOCJFL). (p.81)

Foto 23 - Um dia de bailado no CECOCJFL. (p. 81)

Foto 24 - Músicos em performance musical (CEDPM). (p. 82)

Foto 25 - Músicos em performance musical (CEDPM). (p. 82)

Foto 26 - Músicos em performance musical (CEOCPE). (p. 85)

Foto 27 - Músicos em performance musical (CEOCPE) (p. 86)

Foto 28 - Um dia de bailado no CEOCPE. (p. 86)

Foto 29 - Pintura Mediúnica (Psicopictoriografia) (CEOCPE). (p. 92)

Foto 30 - Hino: Flor das Águas. (p. 99)

Foto 31 - Hino: Do Livro que Recebi (CECOCJFL). (p. 101)

Foto 32 - Hino: Castelo Azulado (CECOCJFL). (p. 115) 


\section{ÍNDICE DE PARTITURAS}

Partitura 1 - Hino: O Poder da Luz do Daime. (p. 27)

Partitura 2 - Hino: Uma Prova de Amor. (p. 41)

Partitura 3 - Hino: Uma Eterna Peregrinação. (p. 42)

Partitura 4 - Hino: Salmo das Romarias. (p. 44)

Partitura 5 - Hino: Poder Curador (p. 46)

Partitura 6 - Hino: São Francisco de Assis. (p. 48)

Partitura 7 - Hino: Castelo Azulado. (p. 49)

Partitura 8 - Hino: Almas na Escuridão. (p. 50)

Partitura 9 - Hino: Batismo. (p. 51)

Partitura 10 - Hino: Do Santo Amor apareceu (p. 52)

Partitura 11 - Hino: Louvores a Virgem Santa do Rosário. (p. 53)

Partitura 12 - Hino: Meu Bom Jesus. (p. 54)

Partitura 13 - Hino: Começamos a Brincar. (p. 56)

Partitura 14 - Hino: São João Batista. (p. 57)

Partitura 15 - Hino: Cruz Bendita (CEDPM) (p. 64)

Partitura 16 - Hino: Cruz Bendita (CEOCPE). (p. 64)

Partitura 17 - Hino: Romaria dos Missionários (CEDPM). (p. 65)

Partitura 18 - Hino: Romaria dos Missionários (CEOCPE). (p. 66)

Partitura 19 - Hino: Soldado de Ordem. (p. 72)

Partitura 20 - Hino: As Obras de Deus (p. 74) 
Partitura 21 - Hino: Troco Troco. (p. 75)

Partitura 22 - Hino: São Francisco das Chagas. (p. 76)

Partitura 23 - Hino: Jesus Crucificado. (p. 77)

Partitura 24 - Análise de célula rítmica. (p. 44)

Partitura 25 - Hino: Santo Anjo da Guarda (p. 84)

Partitura 26 - Hino: Santo Anjo da Guarda. (p. 84)

Partitura 27 - Hino: Culto Santo. (p. 93)

Partitura 28 - Hino: A Preparação. (p. 94)

Partitura 29 - Hino: Mistério Sagrado. (p. 95)

Partitura 30 - Hino: Ave Maria: A Luz que nos guia (p. 97)

Partitura 31 - Hino: A Minha Viagem. (p. 102)

Partitura 32 - Hino: Galardão. (p. 106)

Partitura 33 - Hino: Sentar Firmes na Mesa e Sermos Firmes a Jesus. (p. 107)

Partitura 34 - Hino: Sinal de Paz. (p. 121) 


\title{
RESUMO
}

No ano de 1945 em Rio Branco, capital do estado Acre, o músico maranhense Daniel Pereira de Mattos fundou a doutrina religiosa, popularmente, conhecida como Barquinha. Segundo a tradição, os cânticos que são utilizados nos seus rituais, são recebidos espiritualmente pelos médiuns da Barquinha. Neste trabalho coletamos informações sobre as origens, desenvolvimento e o cotidiano desta tradição cultural, com o objetivo de se produzir uma etnografia da música local, baseada nos pressupostos sugeridos pelo pesquisador Anthony Seeger (2004). O enfoque principal da investigação gira em torno de questões relacionadas à música mediúnica que ali ocorre.

Palavras-chave: Barquinha. Ayahuasca. Música, Religião, Música Mediúnica.

\begin{abstract}
In 1945 in Rio Branco, the capital of the state of Acre, Brazil, a musician from the state of Maranhão, Daniel Pereira de Mattos, founded a religious doctrine, popularly known as The Barquinha. According to tradition, the songs that are used in their rituals are received spiritually by the mediums of this spiritual group. In this work we gather information about the origins, development and daily life of this cultural tradition, with the aim of producing an ethnography of local music, based on the assumptions suggested by the researcher Anthony Seeger (2004). The main focus of the investigation revolves around issues related to the occurrence of this tradition's mediumistic music.
\end{abstract}

Keywords: Barquinha. Ayahuasca. Music, Religion, Mediumistic Music. 


\section{Sumário}

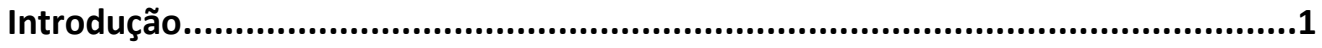

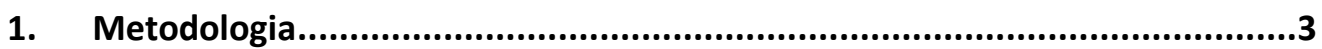

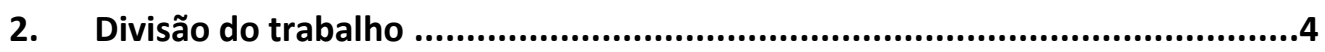

3. Esclarecimentos e reflexões acerca do termo "Barquinha" e outros termos recorrentes no contexto do nosso objeto de estudo .......................................................

Capítulo 1 - Revisão Bibliográfica .......................................................9

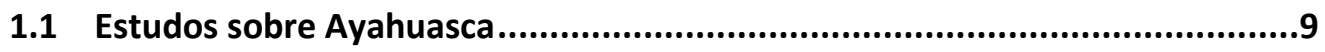

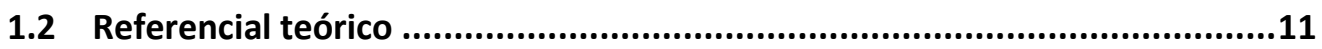

1.3 Outros referenciais importantes na pesquisa........................................13

Capítulo 2 - A Barquinha de Mestre Daniel.............................................. 17

2.1 Breve histórico sobre Mestre Irineu e a doutrina do Santo Daime ...............18

2.2 Mestre Daniel e o prenúncio de sua missão religiosa ..................................20

2.3 A capelinha de São Francisco e os primórdios da Barquinha .........................21

2.4 Dissidências e ramificações: As comunidades da Barquinha ........................23

2.4.1. Centro Espírita e Culto de Oração Casa de Jesus Fonte de Luz (CECOCJFL) .........24

2.4.2. Centro Espírita Luz, Amor e Caridade (CELAC) …………………………….....26

2.4.3. Centro Espírita Daniel Pereira de Matos (CEDPM) ...............................................2

2.4.4. Centro Espírita Obras de Caridade Príncipe Espadarte (CEOCPE) ........................29

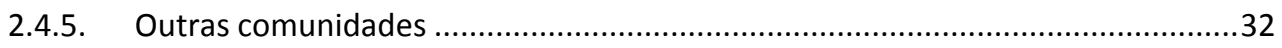

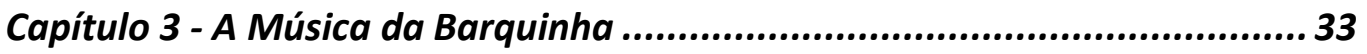

3.1 "Funções" e "usos" da música na (da) Barquinha.........................................33

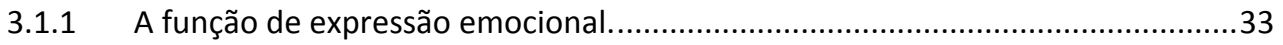

3.1.2 As funções de validação das instituições sociais e rituais religiosos e contribuição

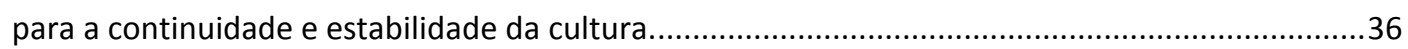

3.1.3 Rotina de atividades (Função litúrgica) ………................................................39

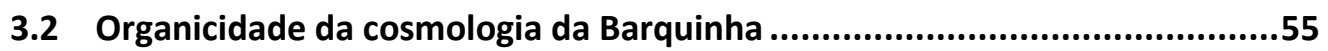

3.3 Desafios da análise musical da música da Barquinha ..............................56

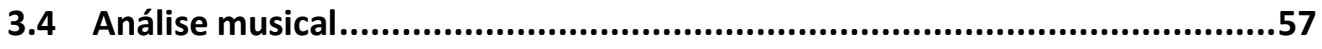




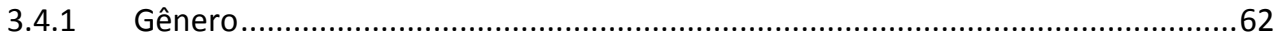

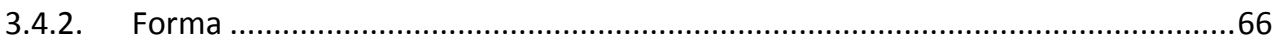

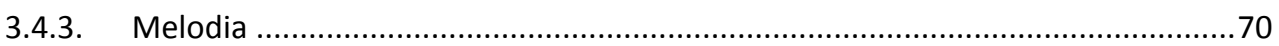

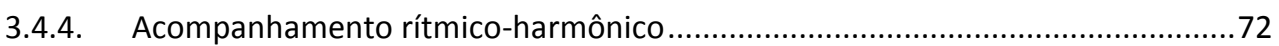

Capítulo 4 - Música mediúnica: 0 "ato de receber hinos"........................... 81

4.1 0 ato de receber hinos: o processo de composição do repertório musical da Barquinha .81

4.2 Descrição do fenômeno à luz do método etnográfico e algumas reflexões. .85

4.3 Análise do fenômeno da música mediúnica na Barquinha..........................88

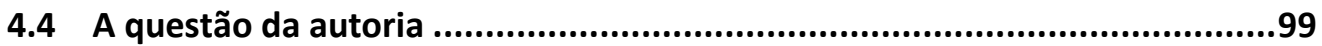

4.5 Reflexões sobre proteção da propriedade intelectual da obra musical da Barquinha .106

4.5.1 Alguns pontos de vistas sobre: Livro Azul, hinário e "donos" dos hinos... 110

Considerações Finais. 114

Referências Bibliográficas. 120 


\section{Introdução}

O presente trabalho aborda um fenômeno social que ocorre na primeira metade do século XX, em plena selva amazônica: uma tradição religiosa sincrética oriunda da síntese de elementos do catolicismo popular, espiritismo, umbanda, xamanismo, entre outros e que utiliza a Ayahuasca ${ }^{1}$ em seus rituais. Esta doutrina cristã popularmente conhecida como Barquinha, ${ }^{2}$ foi fundada pelo maranhense Daniel Pereira de Mattos ${ }^{3}$, em Rio Branco, capital do estado Acre no ano de 1945. Atualmente, em virtude de dissidências e ramificações, diversas comunidades surgiram em torno desta linha religiosa. O presente trabalho tem o objetivo de investigar, à luz da musicologia e de outras disciplinas correlatas, este fenômeno musical e social que alimenta a fé e a religiosidade dos membros destas comunidades.

A música é um elemento de fundamental importância na Barquinha. Segundo a tradição, o conjunto de cânticos entoados em seus rituais é recebido espiritualmente pelos membros da missão de Mestre Daniel, através de um fenômeno mediúnico. É possível afirmar que estas mensagens melodiosas, sagradas para os fiéis, são o cerne deste segmento religioso, pois toda a sua ritualística gira em torno destes cânticos. As relações entre essa música dita mediúnica e esta tradição é o eixo central das análises produzidas nesta investigação. Está em análise aqui a simbiose que ocorre entre as experiências humanas, os sincretismos, as influências culturais e o ato de receber hinos ${ }^{4}$ que segundo a crença local, são as revelações divinas que seriam enviadas aos fiéis em forma de canções, cujos textos são a base da fé e da doutrina deste segmento religioso.

$\mathrm{Na}$ presente pesquisa busquei traçar um panorama da música da Barquinha. Por meio do trabalho etnográfico realizado, descrevo aspectos gerais deste objeto de estudo. Pretendo com isso contribuir para o preenchimento de uma lacuna que hoje existe em torno de um tema que, aos poucos, vem ganhando espaço no mundo acadêmico: o

1 Trata-se de um chá utilizado em rituais religiosos. Esta bebida foi trazida por seringueiros do coração da floresta amazônica, onde era milenarmente utilizada por indígenas de inúmeras etnias e passou a compor a base de algumas tradições religiosas urbanas.

2 Entre os seguidores da Missão de Mestre Daniel não existe unanimidade quanto ao uso do termo Barquinha, entretanto por questões metodológicas, resolvi utilizar o referido termo que ficou popularizado mundialmente. No final desta introdução, darei mais detalhes a respeito deste assunto.

3 De acordo com os relatos obtidos, outros nomes são utilizados para referir-se a Daniel Pereira de Mattos, por exemplo, Mestre Daniel, Frei Daniel e Fundador.

${ }^{4}$ Estou pegando emprestado este termo que já foi utilizado por Sandra Lúcia Goulart (2004) para fazer referência ao fenômeno mediúnico que envolve a constituição do repertório musical da Barquinha. 
universo das religiões ayahuasqueiras e, em particular, o que vem sendo chamado de "Música brasileira de Ayahuasca" (LABATE e PACHECO, 2009). Neste livro, os autores abordam o relevante papel que a música exerce no contexto destas tradições religiosas, por meio de uma pesquisa, que abrangeu duas doutrinas daimistas, o Santo Daime e a União do Vegetal (UDV), ${ }^{5}$ entretanto os autores deixam a Barquinha de fora desta análise, alegando pouca experiência de campo e dificuldade de acesso aos salmos: "Tais exclusões implicam uma perda; esperamos que futuros trabalhos possam preencher essa lacuna" (LABATE e PACHECO, 2009, p. 19).

Nas etapas preparatórias deste projeto, me deparei com uma miríade de possíveis temas dentre os quais poderia focalizar um possível trabalho de pesquisa. Contudo, optei por conduzir uma investigação exploratória em torno do tema: música mediúnica. Em nenhum momento tive o interesse de verificar a veracidade do fato afirmado pelos membros da Barquinha quanto à manifestação de autores desencarnados, ${ }^{6}$ nos moldes como foi conduzida a investigação de Willin (1999), ${ }^{7}$ mas sim interpretar o fenômeno, descrevendo-o à luz do método etnográfico (SEEGER, 2004).

Através dos pontos de vistas dos nativos, busquei compreender algumas questões de interesse particular, como por exemplo, a maneira como descrevem o fenômeno mediúnico que ali ocorre, o qual optei por chamar de o ato de receber hinos. ${ }^{8}$ Qual a relação entre inspiração e música recebida espiritualmente? A quem podemos atribuir a autoria das composições dos hinos recebidos nestas comunidades? Ao me debruçar sobre as questões de pesquisa citadas acima durante o trabalho de campo, outro assunto acabou vindo à tona: até que ponto os Centros da Barquinha estão preocupados em proteger este patrimônio musical que vem se constituindo desde a fundação desta missão religiosa? Dediquei grande esforço dentro desta investigação para buscar esclarecimentos acerca destas questões de pesquisa.

\footnotetext{
${ }^{5}$ O Santo Daime e a União do Vegetal (UDV) são duas tradições religiosas ayahuasqueiras amazônicas, a primeira fundada por Raimundo Irineu Serra na década de 30, em Rio Branco, no Acre, e a segunda fundada por José Gabriel da Costa no início da década de 60 em Rondônia (LABATE e PACHECO, 2009).

${ }^{6}$ Desencarnado é um termo muito utilizado no Espiritismo para designar uma pessoa falecida, ou seja, a alma está fora da carne (matéria), num plano espiritual. Para maiores informações sobre este assunto consultar: (MOURA, 1946).

7 Em suma, na sua tese de doutorado Willin (1999) procurou verificar se os fenômenos mediúnicos estudados por ele poderiam ser de fato verdadeiros, assim como afirmavam ser os médiuns envolvidos nos casos estudados, ou, se era algum tipo de fraude, alucinação psíquica, ou alguma outra causa explicável.

8 Por questões metodológicas, grafarei em itálico os termos específicos utilizados dentro das análises referentes a esta investigação.
} 
De certo modo, poderia dizer que o meu objeto de pesquisa é a Barquinha como um todo. Entretanto, trata-se de um universo muito amplo, pois, atualmente são diversas comunidades que têm ligação com a tradição fundada por Daniel Pereira de Mattos. ${ }^{9}$ Em cada grupo encontramos especificidades de ordem social e cultural que os tornam naturalmente diferentes entre si em muitos aspectos. Por exemplo, ao comparar-se o estilo musical destas igrejas observa-se roupagens diversificadas em cada caso. Diante da complexidade inerente a cada uma destas comunidades e por questões práticas, focalizamos a pesquisa em torno dos três Centros popularmente mais conhecidos - O Centro Espírita e Culto de Oração Casa de Jesus Fonte de Luz, o Centro Espírita Daniel Pereira de Matos e o Centro Espírita Obras de Caridade Príncipe Espadarte.

As partituras e as letras dos cânticos que transcrevi e expus ao longo do trabalho são resultantes da pesquisa de campo. Além do acesso às gravações de áudio do Centro Espírita Daniel Pereira de Matos, tive também acesso a documentos, gravações de áudios e vídeos do acervo do Centro Espírita Obras de Caridade Príncipe Espadarte, gentilmente cedidos para minhas consultas. ${ }^{10}$ As melodias transcritas nas partituras representam a primeira estrofe do hino em questão (em alguns cânticos que possuem um "refrão"; foi transcrito a primeira estrofe seguida do refrão ou vice-versa de acordo com a situação). No geral, a melodia se repete para as demais estrofes, contudo pode haver pequenas variações de acordo com o texto de cada verso. Explico melhor este modo que adotei para ilustrar os cânticos aqui colocados no capítulo 2, mais precisamente, tópico análise musical, seção "Forma" (2.4.2). Cabe ressaltar que frequentemente encontrei diferenças entre as performances musicais das diversas comunidades da Barquinha. É provável que nos demais Centros, os cânticos aqui selecionados contenham variações, no que se refere à letra e a outros aspectos como melodia, métrica, ritmo e etc., voltarei a este assunto mais detalhadamente na seção de análise musical no capítulo $2^{\circ}$.

\section{Metodologia}

Quanto à metodologia, optei pelo método da observação participante, acompanhando o dia a dia da comunidade, frequentando os rituais e entrevistando membros de diversos grupos ligados a esta linha religiosa. Investi a maior parte do

\footnotetext{
${ }^{9}$ Mais adiante, no capítulo 1, falarei sobre as dissidências e ramificações que originaram esta variedade de comunidades ligadas à Barquinha.

${ }^{10}$ A maioria das transcrições foi feita a partir dos áudios fornecidos pelo Centro Espírita Obras de Caridade Príncipe Espadarte.
} 
tempo do trabalho de campo no Centro Espírita Obras de Caridade Príncipe Espadarte. Ademais, foi utilizado com maior frequência as experiências vividas ali para produzir as reflexões a respeito das questões de pesquisa abordadas aqui. Visitei também duas de se suas filiais, uma localizada em Brasília-DF e outra em Niterói-RJ. Além disso, fiz algumas visitas ao Centro Espírita e Culto de Oração Casa de Jesus Fonte de Luz e ao Centro Espírita Daniel Pereira de Matos, ambas localizadas em Rio Branco-AC. Coletei dados e documentos a fim de compreender melhor a formação e o desenvolvimento desta tradição cultural e as questões de interesse desta investigação.

\section{Divisão do trabalho}

Adiante, o trabalho está organizado basicamente em quatro partes. No primeiro capítulo, apresento um panorama da revisão bibliográfica utilizada em toda pesquisa, destacando as principais ferramentas teóricas utilizada nesta dissertação. No segundo capítulo, faço uma contextualização sobre a Barquinha. O objetivo principal desta seção é de familiarizar o leitor com o objeto de estudo, pois trata-se, creio eu, de um assunto pouco conhecido para alguns dos quais irão ler esta dissertação. Inicialmente, foi abordado o contexto histórico do surgimento da Barquinha, ressaltando o personagem principal deste enredo, o fundador da doutrina. Em seguida, destaco os principais acontecimentos que desencadearam a fundação de novas comunidades ligadas à esta tradição a fim de apresentar ao leitor um panorama atualizado da extensão que a mesma adquiriu ao longo de sua existência.

No terceiro capítulo, está descrito aspectos do universo musical deste segmento religioso. Por meio do trabalho etnográfico, aliado a pesquisa bibliográfica, são feitas reflexões sobre a importância e algumas das funções que a música cumpre no contexto geral da Barquinha. Em seguida, descrevo características desta música que vem se estabelecendo ao longo dos anos no seio de cada Centro da Barquinha, expondo alguns elementos musicais identificados por meio da análise musical realizada durante esta investigação, com o objetivo de apresentar ao leitor um panorama geral deste universo musical.

Por fim, no quarto capítulo exponho o resultado do trabalho de campo realizado em torno do tema: "música mediúnica". Descrevendo características e informações referentes ao fenômeno que aqui estou chamando de o ato de receber hinos, que é o 
meio pelo qual as obras musicais da Barquinha são compostas pelos médiuns dos diversos Centros ligados a esta tradição religiosa.

Creio que as informações colhidas e os resultados desta investigação contribuirão com o debate em torno dos temas que estão sendo abordados, podendo servir de ponte para a realização de trabalhos futuros nestas áreas.

\section{Esclarecimentos e reflexões acerca do termo "Barquinha" e outros termos recorrentes no contexto do nosso objeto de estudo}

Como abordado com mais detalhes no capítulo $1^{\circ}$, Daniel Pereira de Mattos iniciou sua jornada missionária nos confins da região amazônica no ano de 1945. Nos 12 anos que cumpriu o seu compromisso religioso até seu falecimento, Mattos constituiu uma comunidade de seguidores. Dentro de um contexto de dissidências e ramificações, atualmente, esta "comunidade de seguidores" se expandiu de tal forma que, atualmente, foi possível identificar por meio desta investigação a existência de membros oficiais ${ }^{11}$ e simpatizantes em várias regiões do Brasil e do mundo.

De acordo com as informações coletadas em campo, referenciar à doutrina religiosa fundada por Daniel Pereira de Mattos, como "Barquinha" ou "linha da Barquinha" não é uma unanimidade para os seus seguidores. Na dissertação de Mestrado de Ricardo Assarice dos Santos (2017), o mesmo relata que:

(...) o atual presidente do Centro Espírita e Culto de Oração Casa de Jesus Fonte de Luz, Francisco Hipólito de Araújo Neto, não gosta desta nomenclatura - Barquinha - para se referir à sua unidade. $\mathrm{Na}$ visão do atual presidente, a igreja que o mesmo gerencia seria a única legítima e se diferenciaria das outras linhagens (Centros), tema amplamente discutido por Magalhães (2013), que inclusive não utiliza o termo Barquinha em seu trabalho. (p. 37)

Segundo Santos (2017), em um evento intitulado: “AYA2016: II Conferência Mundial da Ayahuasca", que aconteceu em Rio Branco (AC) em 2016, o presidente do referido Centro, teria corrigido "pesquisadores em suas apresentações quando os mesmos se referiram à sua unidade (Centro) como Barquinha (...).” (p. 37)

Dentro do contexto da missão de Mestre Daniel, a utilização e a popularização do termo "Barquinha" teria se desencadeado a partir da somatória de inúmeros acontecimentos. Em entrevista, Antônio Geraldo da Silva Filho, Presidente do Centro

\footnotetext{
${ }^{11}$ Nos Centros da Barquinha, os membros “oficiais" são aqueles que se "fardaram”, ou seja, oficializaram um compromisso religioso em algum determinado Centro.
} 
Espírita Daniel Pereira de Matos, relatou alguns fatos que ajudam a entender como isto se deu. O primeiro fato que destaco do relato do nosso entrevistado é o fato de seu pai, o Mestre Antônio Geraldo, ${ }^{12}$ "ter recebido" ainda na comunidade primogênita da Barquinha, alguns hinos que trazem no bojo de suas narrativas os termos "Barquinha", ou, "Barquinho", fazendo referência à Missão religiosa fundada por Mestre Daniel. Coloco a seguir uma foto tirada do álbum "Antônio Geraldo: o marinheiro da Luz", contendo um hino "recebido" por ele no Centro Espírita e Culto de Oração Casa de Jesus Fonte de Luz:

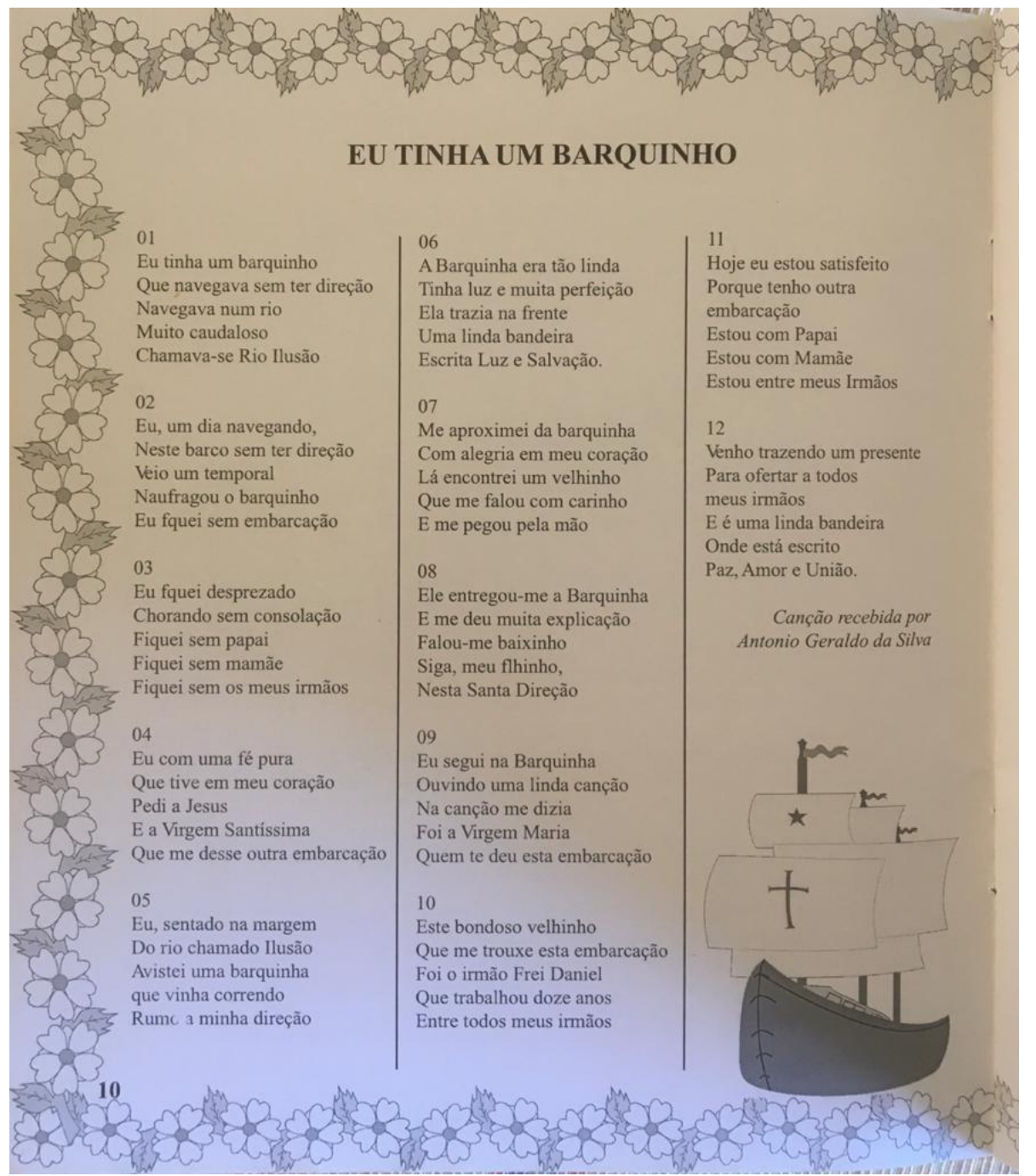

Foto 1 - Hino "Eu tinha um Barquinho". Fonte: (Fundação Garibaldi Brasil / Emurb, 2007, p.10)

De fato, as mensagens que as entidades espirituais estariam trazendo para os médiuns - aliadas ainda ao fato de Mestre Daniel ter sido marinheiro em sua juventude,

12 Mestre Antônio Geraldo foi o sucessor de Mestre Daniel, o presidente da primeira comunidade institucionalizada da Barquinha. 
entre outros fatos identificados em campo ${ }^{13}$ - dão pistas que trazem à luz o modo como se deu a introdução de símbolos "marinhos" dentro da cosmologia da missão religiosa fundada por Mestre Daniel.

O segundo fato que destaco do relato do nosso entrevistado, revela uma situação que findou popularizando o nome Barquinha. Segundo ele, os hinos que o seu pai recebeu ao longo de sua jornada na missão de Mestre Daniel, já davam pistas que indicavam o nome Barquinha, entretanto:

(...) não era tido como "A Barquinha", o pessoal ainda não tinha atentado para isso, foi quando no Centro Espírita Daniel Pereira de Matos... morava um jornalista de nome... Silvio Martinele, então ele... pra fazer uma média ali na prefeitura, num programa de rádio dele, ele falava: "olha, seu prefeito, dá uma olhadinha na rua da Barquinha," porque ele via o parque que nós fizemos para fazer o bailado, era no formato de um barco, então todo mundo começou a ver como um barco... os hinos que ele ouvia de lá da casa dele... e daí então passou a ser conhecido como "A Barquinha"... hoje, mundialmente é conhecido como Barquinha.

Em campo, vi que de fato, muitos membros da Missão e da sociedade, em geral, consideram este nome. Além disso, vários trabalhos acadêmicos têm adotado o nome "Barquinha", ou "Barquinho" ou "Barquinha Santa Cruz", este último, utilizado pelo próprio Francisco Hipólito ao término da apresentação escrita por ele numa publicação intitulada: "Mestre Daniel - história com a Ayahuasca:

O nosso objetivo é registrar os longos anos em que Mestre Daniel deixou de pertencer à Marinha Brasileira, como $2^{\circ}$ sargento, para ser um humilde soldado das forças armadas dos exércitos de Jesus, no leme da Barquinha Santa Cruz, deste mundo à eternidade. (MARGARIDO \& ARAÚJO NETO, 2005, p. 8)

Não é o tema desta dissertação a questão dos conflitos que existem dentro do âmbito da missão de Mestre Daniel. ${ }^{14}$ Entretanto, na medida em que se faz necessário, toco em assuntos que são motivos de impasses entre "alguns membros da Barquinha". Com isso, não tenho o intuito de "acirrar" uma hipotética disputa ideológica entre as partes, mas sim clarificar ao máximo possível alguns dos fatos que dizem respeito aos temas aqui abordados.

Outros termos utilizados aqui e que carecem de esclarecimentos são as classificações utilizadas pelos nativos ao se referirem aos cânticos que são recebidos no

\footnotetext{
13 Aqui pode-se incluir também, uma de suas experiências místicas que foi relatada por uma de nossas entrevistadas, conforme será exposto no capítulo 1.

${ }^{14}$ Este assunto é abordado com mais detalhes em (GOULART, 2004).
} 
âmbito da missão de Mestre Daniel, a saber: hino, salmo, bendito, soneto, ponto, canções inspiradas, hino-salmo, hino-ponto, hino-canção e hino-oração. Observei a utilização destas nomenclaturas durante o nosso trabalho de campo, tanto por meio das entrevistas realizadas, quanto por meio da consulta de documentos e da bibliografia utilizada na pesquisa.

Em suma, não identifiquei uma definição clara em relação aos conceitos de cada um desses nomes. No contexto da Barquinha, por exemplo, é confuso diferenciar, conceitualmente falando, um salmo de um hino, ou até mesmo de um bendito, e assim por diante. Por outro lado, fica mais claro o entendimento do que seriam os pontos, que são uma espécie de "chamadas" entoadas no gongá (local aonde os médiuns trabalham incorporados com as entidades), e nos festejos (bailados, ou giras) com o objetivo de invocar as entidades espirituais, os orixás e etc.. Com exceção dos pontos, as demais classificações citadas acima seriam os cânticos entoados geralmente dentro dos cultos no interior do templo.

Outra pista conseguida sobre este assunto é referente ao fato de que a classificação de um cântico pode ser feita através da identificação de um ou mais destes termos citados no corpo do texto das mensagens. Quando encontramos, por exemplo, ao longo da letra de um cântico da Barquinha, a citação da palavra "salmo", o mesmo poderia receber esta denominação, ou ainda, quando encontramos na letra da música expressões do tipo, "Este Bendito que estou rezando", provavelmente, tal cântico seria classificado como um "Bendito" e assim por diante.

Destarte, faço questão de deixar claro que as reflexões produzidas, ao longo do trabalho, assim como, por exemplo, o partido que tomei ao utilizar o nome Barquinha para fazer referência às comunidades que possuem vínculos com a missão de Mestre Daniel, representam o ponto de vista do pesquisador, ou seja, a maneira como estou interpretando este contexto histórico-social. 


\section{Capítulo 1 - Revisão Bibliográfica}

Nesta seção, exponho um resumo do resultado da pesquisa bibliográfica realizada no período desta investigação.

\subsection{Estudos sobre Ayahuasca}

Segundo a tradição a Ayahuasca (também conhecido como Daime, ou Santo Daime, Nixi Pae, Hoasca, Yagé, Vegetal, Santa Luz, entre outros nomes) é um chá utilizado por civilizações indígenas milenarmente. Trata-se de uma bebida psicoativa produzida a partir da combinação do cipó Banisteriopsis Caapi (também conhecido como Mariri ou Jagube) com a folha Psychotria Viridis (também conhecida como Chacrona ou Folha Rainha).

Observa-se no início do século XX o surgimento de três segmentos religiosos urbanos amazônicos que agregaram o uso da Ayahuasca às suas ritualísticas: A linha fundada pelo maranhense Raimundo Irineu Serra em 1930, popularmente conhecida como Santo Daime; a doutrina cujo fundador foi outro maranhense, Daniel Pereira de Mattos, comumente chamada por Barquinha em 1945; e por fim, a União do Vegetal, tradição fundada pelo baiano José Gabriel da Costa em 1961.

É preciso ressaltar que a presente dissertação é, de certa forma, uma continuidade de meu trabalho de pesquisa relativo à tradição religiosa fundada por Daniel Pereira de Mattos. Em 2013 tive a oportunidade de concluir a minha graduação em Ciências Sociais pela UFAC com a monografia: A Barquinha da Madrinha Chica Gabriel: refletindo sobre a formação de uma comunidade religiosa. Nesta pesquisa, procurei descrever a maneira como surgiu e vem se formando o Centro Espírita e Obras de Caridade Príncipe Espadarte, uma das comunidades ligadas à Barquinha, localizada na capital do Estado do Acre e liderada pela Madrinha Francisca Campos do Nascimento, conhecida como Chica Gabriel. Neste estudo, comunidade é tratada de um ponto de vista processual, e o conceito envolvido é o de "comunitarização", tal como formulado por Max Weber. Ou seja, buscou-se tratar "comunidade" não como um produto acabado, e sim como um processo orgânico e dinâmico.

Muitas informações referentes à origem e contexto histórico da Barquinha foram colhidas de diversos trabalhos publicados. Destaco aqui dois livretos produzidos por Francisco Hipólito de Araújo Neto em conjunto com outros estudiosos que têm 
realizado um importante trabalho de pesquisa histórica sobre a vida de Daniel Pereira de Mattos: "Mestre Daniel: História com a Ayahuasca" (MARGARIDO \& ARAÚJO NETO, 2005) e "No caminho de Mestre Daniel" (ARAÚJO NETO et al, 2010). Por meio destas fontes temos acesso a muitos documentos e informações históricas sobre a vida de Mestre Daniel e a doutrina religiosa fundada por ele.

Além destas publicações, destaco aqui alguns trabalhos por meio dos quais encontrei muitas informações importantes para o desenvolvimento desta dissertação: O primeiro é: "Contrastes e continuidades em uma tradição Amazônica: as religiões da Ayahuasca", Tese de Doutorado em Ciências Sociais pela Unicamp, na qual Sandra Lucia Goulart (2004) enfoca a comparação entre as tradições religiosas amazônicas que utilizam a Ayahuasca em seus cultos (Santo Daime, Barquinha e União do Vegetal), com suas várias fragmentações e desdobramentos que acarretaram na proliferação de inúmeras comunidades ditas ayahuasqueiras. O segundo trabalho é: "Balanços de Luz: devoção e experiência a bordo do Barquinho Santa Cruz", tese de doutorado em Ciências Sociais pela UFCG de Eloi dos Santos Magalhães (2013), na qual foi investigado a forma de religiosidade e devoção praticada em um dos Centros ligados a Barquinha em Rio Branco no Acre. A terceira pesquisa é: "A híbrida Barquinha: Uma revisão da história, das principais influências religiosas e dos rituais fundamentais", Dissertação de Mestrado em Ciências da Religião pela PUC-SP de Ricardo Assarice dos Santos (2017) na qual o autor buscou identificar e apresentar o contexto histórico, as principais influências religiosas e os rituais fundamentais da linha da Barquinha. Outro trabalho onde coletei informações muito úteis para a presente pesquisa foi: "De folha e cipó é a Capelinha de São Francisco: a religiosidade popular na cidade de Rio Branco - Acre (1945-1958) ”, Dissertação de Mestrado em História do Brasil - UFAC/UFPE, na qual Rosana Martins de Oliveira (2002) buscou descrever características do contexto histórico cultural que envolve as origens e desenvolvimento da Barquinha por meio dos fatos históricos pertencentes a esta tradição religiosa.

Além destes trabalhos citados acima, outras fontes de informações sobre à Barquinha consultadas durante a pesquisa foram: (ARAÚJO, 1999); (MERCANTE, 2012); (FRENOPOULO, 2005); (PASKOALI, 2002) e (COSTA, 2008).

Atualmente, existe uma série de trabalhos que abordam o tema Ayahuasca e seus usos rituais. Dentre eles, "O uso ritual da Ayahuasca”, obra publicada no Brasil em 2002 e organizada por Beatriz Caiuby Labate e Wladimyr Sena Araújo, que reúne diversas pesquisas sobre esse assunto. Neste livro encontramos contribuições de 
antropólogos, farmacólogos, médicos e representantes das três principais religiões ayahuasqueiras brasileiras citadas logo acima.

Sobre os contextos históricos relativos as doutrinas do Santo Daime e UDV existem inúmeras fontes de pesquisa que vão desde trabalhos acadêmicos (Tccs, dissertações, teses, artigos científicos e etc.), a diversos livros publicados por pesquisadores, historiadores e simpatizantes do tema, além de informações disponíveis na internet de um modo geral. Deixo aqui algumas referências consultadas durante a pesquisa: (MACRAE, 1992); (GROISMAN, 1999); (MONTEIRO DA SILVA, 1983); (MONTEIRO DA SILVA, 2002) (MORTIMER, 2000); (GOULART, 1996); (GOULART, 2004); (LABATE, 2000) e (FRÓES, 1986); (RODRIGUES, 1998); (DIAS JR., 1992); (CEMIN, 1998); (BRISSAC, 1999); (www.santodaime.org); (https://udv.org.br/); (https://barquinhosantacruz.wixsite.com/cedpm);

\subsection{Referencial teórico}

A principal ferramenta teórica escolhida para o desenvolvimento desta pesquisa foi o artigo "A etnografia da música" de Anthony Seeger (2004). Para o autor, a base da etnografia da música é a descrição detalhada dos inúmeros elementos que compõem a performance musical (...) envolvem músicos, um contexto no qual eles executam sua música e uma audiência. (Seeger, 2004, p. 238). Trata-se, portanto, de um fenômeno cultural dinâmico, pois cada evento terá suas próprias especificidades. Segundo Anthony Seeger (2004):

A performance musical possui aspectos fisiológicos, emocionais, estéticos e cosmológicos. Tudo isso está envolvido no por que pessoas fazem e apreciam certas tradições musicais. Uma etnografia da música deve estar preparada para tratar desses aspectos - mesmo que poucos autores o tenham feito. Algumas análises se concentram na influência fisiológica, outras na tensão emocional liberada através da música, outras tratam da correlação social e outras dos efeitos das crenças cósmicas no interior da tradição. Provavelmente, todos estão envolvidos seja qual for a tradição. Uma combinação de pesquisa de campo, investigação das categorias nativas e uma descrição cuidadosa são as marcas da etnografia da música. (p.256)

Seeger sustenta a tese de que a transcrição musical, a etnografia e a antropologia têm objetivos distintos. A primeira representa a escrita dos sons, a segunda tem o objetivo de descrever os povos (etnias) a partir do ponto de vista de quem observa (pesquisador), enquanto a terceira é uma disciplina acadêmica que teoriza sobre 
sociedades humanas. Deste modo, portanto, segundo Seeger, a etnografia da música não deveria ser uma antropologia da música:

(...) já que a etnografia não é definida por linhas disciplinares ou perspectivas teóricas, mas por meio de uma abordagem descritiva da música, que vai além do registro escrito de sons, apontando para o registro escrito de como os sons são concebidos, criados, apreciados e como influenciam outros processos musicais e sociais, indivíduos e grupos. (p.239)

No intuito de se chegar a uma definição acerca do termo "música", o autor parte do ponto de vista de que não se deve confundir música com som. Qualquer objeto é passível de produzir algum tipo de som. Os rádios, por exemplo, emitem sons sem a ação humana, embora seja uma reprodução do produto musical, algo virtual. Música, necessariamente, seria interação, uma forma de comunicação de membros de uma comunidade, por meio da manipulação dos sons, considerando que diferentes grupos podem organizar os sons de maneiras distintas, de acordo com a sua cultura.

A definição de música como um sistema de comunicação enfatiza suas origens e destinações humanas e sugere que a etnografia (escrita sobre música) não somente é possível, mas é uma abordagem privilegiada no estudo da música. A ilusão de que a música pode existir independente de seus performers e de sua audiência tem conduzido à confusão, longos debates e a uma tendência a tratar etnomusicologia como um campo dividido, no qual escritores analisam sons ou analisam características culturais e sociais do fazer musical (Merriam, 1964, p.vii). Mesmo que Alan Merriam e Bruno Nettl (1983, p. 5) sustentem que ambos os grupos de escritores concordam que uma fusão definitiva entre o antropológico e o musicológico seria ideal, as várias ideias sobre o que é música têm gerado resultados muito diversos. (p. 239)

A partir desse raciocínio, o autor critica o divisionismo que se estabeleceu nas pesquisas etnomusicológicas. Ele afirma que a relação entre música, performers e audiência não podem ser desvinculadas durante as investigações. Assim procedendo estaríamos dividindo o campo de estudo: uns focam somente na análise do som, enquanto outros se debruçam sobre as questões culturais e sociais e dão pouca atenção à música propriamente dita. Na tentativa de "unir" o campo divido, Seeger sugere outra abordagem às pesquisas, partindo de pressupostos salutares para se realizar uma etnografia da música, ou seja, questões gerais que aproximem o pesquisador e o seu objeto de estudo e não desvinculem música, performers e audiência do seu contexto.

Em vez de perseguir a definição do que a etnomusicologia deveria ser, vamos observar as questões gerais sobre música (...) O que acontece quando as pessoas fazem música? Quais são os princípios que organizam as combinações de sons e seu arranjo no tempo? Por que 
um indivíduo particular ou grupo social executa ou ouve os sons no lugar, no tempo e no contexto que eles(as) o fazem? Qual a relação da música com outros processos nas sociedades ou grupos? Quais efeitos as performances musicais têm sobre os performers, a audiência e outros grupos envolvidos? De onde vem a criatividade musical? Qual o papel do indivíduo na tradição, e o da tradição na formação do indivíduo? Qual a relação da música com outras formas de arte? (...) Quais questões são focalizadas e como tentamos respondê-las depende da combinação de interesses pessoais e profissionais ou da orientação cultural. (...) interessados em fisiologia poderão estudar as mudanças fisiológicas nos performers e na audiência; aqueles interessados no desenvolvimento das crianças poderão estudar a socialização delas através da música; (...) interessados em religião poderão estudar a relação do evento com ideias sobre o cosmos e a experiência do transcendente. (...) Cada abordagem pode contribuir para nossa compreensão dos eventos musicais, e cada uma pode contribuir com outra disciplina (psicologia, sociologia, economia, antropologia, folclore, musicologia, ciência política) através do estudo da atividade musical. (p. 240 - 241)

Ao sugerir tais caminhos, o autor disponibiliza diretrizes fundamentais para a pesquisa etnomusicológica. Fica a critério de cada estudioso selecionar ou interpretar as questões a seu modo de acordo com os interesses particulares. No caso desta investigação, escolhemos algumas das questões sugeridas por Seeger, as quais têm relação direta com o nosso objeto de estudo para direcionar uma etnografia da música da Barquinha, inclusive, no trabalho de campo aplicamos tais questões às perguntas que fizemos aos nossos entrevistados.

\subsection{Outros referenciais importantes na pesquisa}

Para falar sobre as funções que a música cumpre no contexto geral da Barquinha utilizo como suporte teórico os seguintes trabalhos: primeiramente a antológica obra The Antropology of music de Alan P. Merriam (1964), na qual desenvolve uma ampla abordagem em torno da questão dos usos e funções da música no contexto das civilizações humanas.

Os usos e funções da música representam um dos mais importantes problemas na etnomusicologia, pois no estudo do comportamento humano buscamos constantemente, como foi apontado repetidamente nestas páginas, não apenas os fatos descritivos sobre a música, mas, mais importante, o significado da música. Os fatos descritivos, embora em si mesmos de importância, dão sua contribuição mais significativa quando são aplicados a problemas mais amplos de compreensão do fenômeno que foi descrito. Desejamos saber não apenas o que é uma 
coisa, mas, mais significativamente, o que ela faz pelas pessoas e como o faz. ${ }^{15}$ (p. 209) (Tradução minha)

Para abordar este assunto, Merriam inicialmente diferencia os conceitos de "uso" e "função", alegando que no passado, os etnomusicólogos não consideraram que tais termos, apesar de serem complementares podem possuir significados distintos. Segundo ele, em suma, falar sobre os "usos" da música é fazer referência ao modo como humanidade pode utilizá-la nos mais diversos contextos sociais, como uma espécie de ferramenta usada na execução de tarefas específicas, enquanto "função" pode ter um sentido mais amplo.

A música é usada em certas situações e torna-se parte delas, mas pode ou não ter uma junção mais profunda. Se o amante usa a canção para cortejar sua amada, a função dessa música pode ser analisada como a continuidade e perpetuação do grupo biológico. Quando o religioso usa música para se aproximar de seu Deus, ele está empregando um mecanismo específico em conjunto com outros mecanismos, como dança, oração, ritual organizado e atos cerimoniais. A função da música, por outro lado, é inseparável aqui da função da religião, que talvez possa ser interpretada como o estabelecimento de um sentimento de segurança em relação ao universo. "Uso", então, referese à situação em que a música é empregada na ação humana; "função" diz respeito às razões de seu emprego e, particularmente, ao propósito mais amplo a que serve. ${ }^{16}$ (p. 210) (Tradução minha)

Para Merriam a música é, dentre todas as atividades culturais humanas, provavelmente, a mais onipresente e a que tem mais poder de modelar e controlar o comportamento do homem. Ao que tudo indica, todo esforço empregado pelo autor para esclarecer esta distinção conceitual entre os termos "uso" e "função" tem o objetivo de focalizar e ampliar o entendimento acerca da importância desta arte para as civilizações humanas. Ele busca com isso tratar do tema funções da música no sentido mais amplo possível. Em sua pesquisa identificou algumas funções gerais da música no seio das

\footnotetext{
15 The uses and functions of music represent one of the most important problems in ethnomusicology, for in the study of human behavior we search constantly, as has been pointed out time and time again in these pages, not only for the descriptive facts about music, but, more important, for the meaning of music. Descriptive facts, while in themselves of importance, make their most significant contribution when they are applied to broader problems of understanding the phenomenon which has been described. We wish to know not only what a thing is, but, more significantly, what it does for people and how it docs it.

16 Music is used in certain situations and becomes a part of them, but it may or may not also have a deeper junction. If the lover uses song to woo his love, the function of such music may be analyzed as the continuity and perpetuation of the biological group. When the supplicant uses music to approach his god, he is employing a particular mechanism in conjunction with other mechanisms such as dance, prayer, organized ritual, and ceremonial acts. The function of music, on the other hand, is inseparable here from the function of religion which may perhaps be interpreted as the establishment of a sense of security visa-vis the universe. "Use" then, refers to the situation in which music is employed in human action; "function" concerns the reasons for its employment and particularly the broader purpose which it serves.
} 
sociedades humanas. No meu trabalho de investigação, busquei identificar alguns usos e funções da música no contexto da Barquinha correlacionando-as com algumas das funções propostas por Merriam, como será abordado no Capítulo terceiro.

Ainda para tratar do assunto funções da música, também dialogo com (LABATE e PACHECO, 2009). No livro Música Brasileira de Ayahuasca, encontramos uma abordagem sobre o uso da música em algumas tradições ayahuasqueiras que muito se relaciona com as ideias que estamos colocando no texto.

Continuando as reflexões do capítulo 3, faço uso das ideias de (ARAÚJO, 1999), No livro: "Navegando sobre as ondas do Daime: História, cosmologia e ritual da Barquinha”, fruto do mestrado de Wladimir Sena Araújo em Ciências Sociais pela Universidade de Campinas, o autor elabora uma teoria para explicar esta notável capacidade que a Barquinha tem de se modelar ao longo do tempo e do espaço.

\footnotetext{
Pensamos que se trata de uma cosmologia em construção. De cosmologia em construção denominamos um conjunto de práticas religiosas que tendem a formar uma doutrina específica, em que existe uma grande velocidade na incorporação e retirada de elementos simbólicos das práticas religiosas ou filosóficas que, combinadas, compõem sua cosmologia. (1999, p.74)
}

Para sustentar as reflexões e os conceitos teóricos abordados no tópico de análise musical, recorremos a diversos trabalhos, entre os quais: (ANTUNES, 2003); (AGAWU, 1996); (OLIVEIRA, 2002); (BEARD e GLOAG, 2005): (JAN LA RUE, 1989); (COPLAND, 1974).

Para falar sobre o processo composicional do repertório musical da Barquinha e sua relação com o tema: música mediúnica, dialogo com alguns trabalhos que abordam esta temática. Introduzindo esta seção coloco reflexões de Bruno Nettl contida em sua antológica obra The Study of Ethnomusicology. Em seguida, exponho algumas ideias de Melvyn J. Willin (1999) para embasar alguns conceitos trabalhados na pesquisa. Outro trabalho utilizado foi a dissertação de mestrado de Rodrigo Sebastian de Moraes Abramovitz (2003), "Música e Miração: uma análise etnomusicológica dos hinos do Santo Daime", no qual o autor buscou identificar as relações entre música, miração (transe), ritual, cultura e comunidade da tradição religiosa ayahuasqueira fundada por Raimundo Irineu Serra. Utilizo também um artigo de Lucas Kastrup Rehen (2007), "Receber não é compor: música e emoção na religião do Santo Daime", cujo foco é a análise da maneira como os membros do Santo Daime interpretam a gênese dos hinos religiosos em sua relação com os pensamentos, sentimentos e subjetividade. 
Finalmente, com o objetivo de aprofundar as reflexões acerca da questão referente à proteção legal do legado musical da Barquinha, dialogo com as ideias contidas no artigo de Carlos Sandroni (2007): Propriedade Intelectual e Música de Tradição Oral. Neste artigo, o autor faz uma abordagem em torno dos problemas relacionados à legislação dos direitos autorais quando o assunto é proteger o patrimônio musical pertencente a: “grupos sociais subalternos” (SANDRONI, 2007, p. 1). 


\section{Capítulo 2 - A Barquinha de Mestre Daniel}

Daniel Pereira de Mattos nasceu em 13 de julho de 1888, no estado do Maranhão, no município de São Sebastião da Vargem Grande, a 170 km de São Luís. Sandra Lúcia Goulart (2004) obteve estes dados com Francisco Hipólito de Araújo Neto, atual dirigente do Centro Espírita e Culto de Oração Casa de Jesus Fonte de Luz $^{17}$. Francisco vem realizando, ao longo dos anos, um importante trabalho de pesquisa com o objetivo de atualizar os dados biográficos referentes à Mestre Daniel. Ele e uma equipe de colaboradores obtiveram acesso a alguns documentos que comprovam a chegada de Daniel no Acre em 1907, e outros que indicam sua estadia na capital acreana ainda na primeira década do século XX.

Sabemos que Daniel foi marinheiro durante vários anos. Conta-se que foi por meio desta profissão que ele veio se estabelecer no Acre. Francisco pesquisou alguns documentos junto à Marinha brasileira, os quais atestam que Daniel Pereira de Mattos chegou ao Acre pela primeira vez em 1905, no navio Benjamin Constant. Este realizava uma viagem de instrução de aprendizes de marinheiros, passando rapidamente pelo Acre e depois dirigindo-se para Europa e Jerusalém. Apenas dois anos após terminar este percurso, em 1907, o navio retornou ao Acre, trazendo novamente Daniel (...). O trabalho na marinha, bem como uma série de aspectos relacionados a ele, serão elementos fundamentais na formação de Daniel e influenciarão, de forma marcante, a religião organizada por ele no Acre. (p.116)

Mestre Daniel ficou conhecido como um homem habilidoso que exercia doze profissões: construtor naval, carpinteiro, marceneiro, pedreiro, artesão, poeta, sapateiro, padeiro, cozinheiro, músico, barbeiro e alfaiate (ARAÚJO, 1999). Como músico, tocava violino, trompete, violão e clarineta. (MERCANTE, 2012). Conta-se que era boêmio e sofria problemas de saúde em razão do alcoolismo, e por este motivo teria ficado bastante enfermo. Foi diante deste momento difícil que Raimundo Irineu Serra, fundador de uma tradição religiosa, popularmente conhecida como "Santo Daime", ofereceu a Daniel um tratamento com um chá considerado sagrado pelos adeptos destes segmentos religiosos.

Conta-se que, antes de dedicar-se à atividade religiosa, ele teve uma vida boêmia, sempre frequentando festas, nas quais sua presença era constantemente requisitada por ser um exímio violeiro. Francisco Hipólito de Araújo diz que sua primeira esposa, Maria Viegas, o abandonou exatamente devido ao seu vício da bebida e estilo de vida. Isto teria ocorrido em 1938, quando ela, sabendo que Daniel

\footnotetext{
${ }^{17}$ Foi primeiro Centro a ser instituído após o falecimento de Mestre Daniel em 1958.
} 
encontrava-se em mais uma de suas "noitadas", fugiu acompanhada de seus filhos, voltando para o Maranhão, seu estado natal. Este, segundo Francisco, foi um dos acontecimentos que motivaram Daniel a aceitar o tratamento com Daime sugerido pelo Mestre Irineu. (Goulart, 2004, p.115)

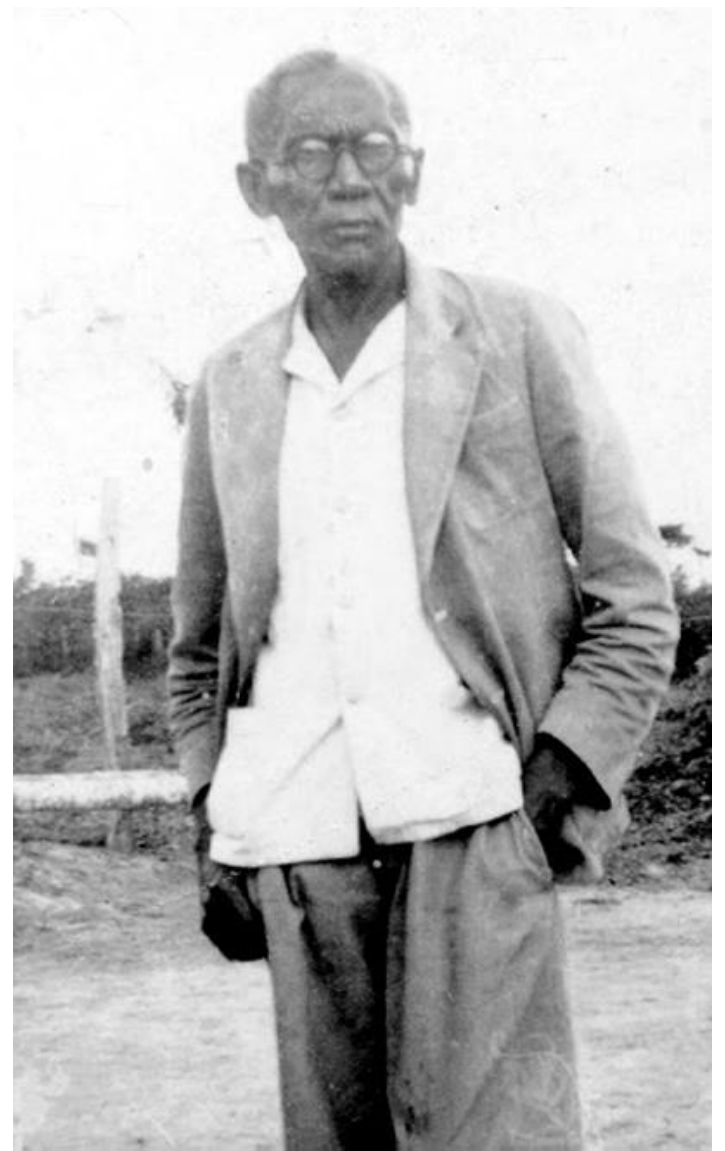

Foto 2 - Um dos poucos registros fotográficos de Daniel Pereira de Mattos. Fonte: Acervo CEOCPE

\subsection{Breve histórico sobre Mestre Irineu e a doutrina do Santo Daime}

O maranhense Raimundo Irineu Serra (1892 - 1971), mais conhecido como Mestre Irineu (MACRAE, 1992), chegou ao Acre por volta do início do século XX. Seringueiro, cuja alta estatura impressionava a todos, Irineu Serra trabalhou nas florestas acreanas extraindo o látex na época da $1^{a}$ guerra mundial. Em 1930 funda o segmento religioso popularmente conhecido como a doutrina do "Santo Daime" (FRÓES, 1986), tradição cultural acreana que utiliza a ayahuasca em seus rituais. 


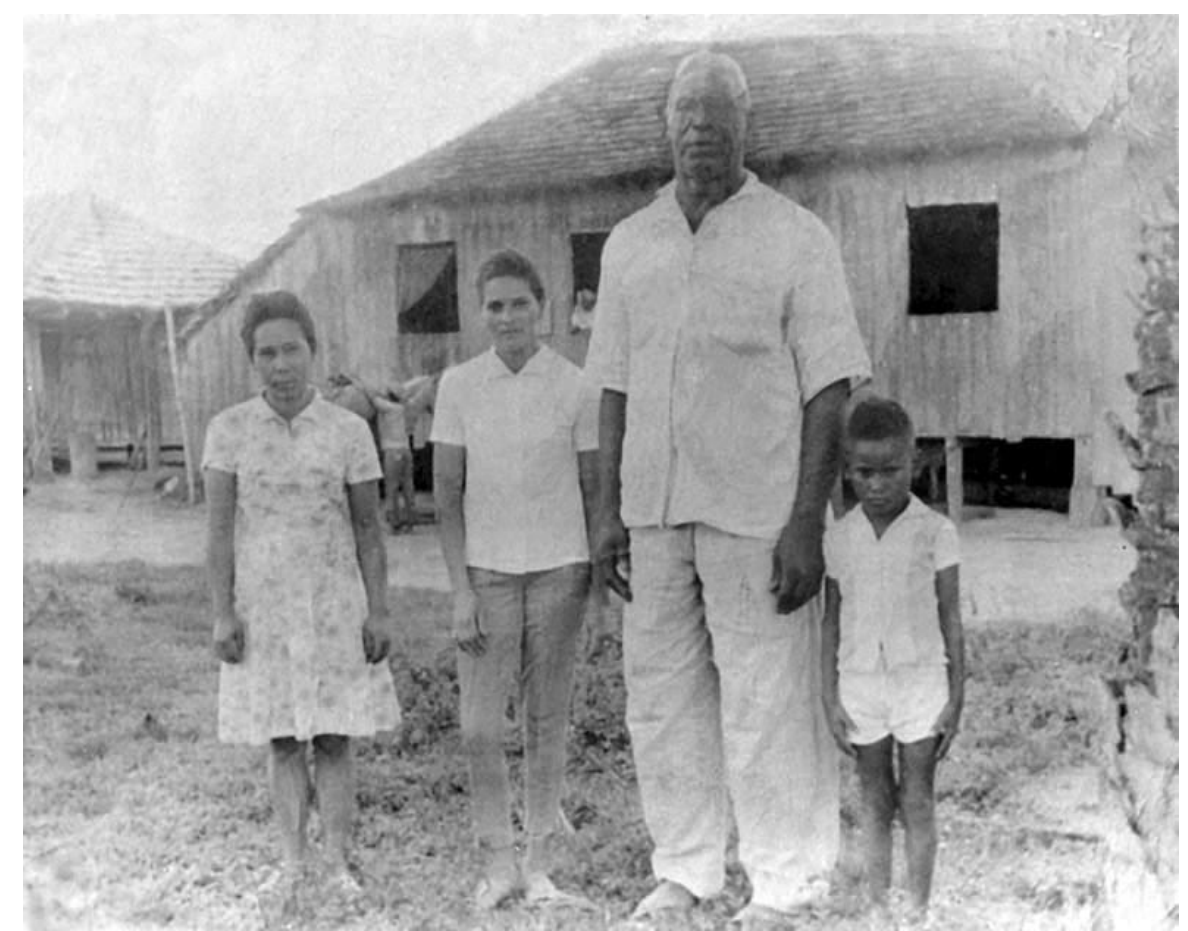

Foto 3 - Mestre Irineu Serra, o $3^{\circ}$ da esquerda para a direita. Fonte: Internet

Ao longo dos anos, a doutrina fundada por Mestre Irineu foi se consolidando no Acre. Por conta de dissidências e ramificações, existem hoje inúmeras comunidades que, de uma forma ou de outra, são derivações desta tradição religiosa. ${ }^{18}$ Durante a pesquisa, identifiquei grupos em vários estados brasileiros e em países como Holanda, Espanha, EUA, Canadá, Japão entre outros. ${ }^{19} \mathrm{O}$ grande responsável por esta expansão teria sido Sebastião Mota de Melo, um dos seguidores de Mestre Irineu e fundador do CEFLURIS (Centro Eclético da Fluente Luz Universal Raimundo Irineu Serra).

Segundo as informações coletadas, Daniel Pereira de Matos, em meados da década de 30, teria estado bastante enfermo, tendo recebido ajuda de Mestre Irineu na forma de um tratamento com o daime, em benefício da saúde de seu conterrâneo. Para os fiéis, este chá é uma bebida sagrada, um sacramento, um santo remédio, que tem o poder de curar males do corpo e da alma. Esta experiência representou a iniciação de Daniel Pereira de Mattos com o daime, e, consequentemente, sua trajetória espiritual.

18 Para maiores informações a respeito deste assunto, consultar a tese de doutorado de Sandra Lúcia Goulart (2004): "Contrastes e Continuidades em uma Tradição Amazônica: As Religiões da Ayahuasca". ${ }^{19}$ Mais informações sobre a expansão nacional e internacional do Santo Daime pode ser obtidas através do sítio: www.santodaime.org 


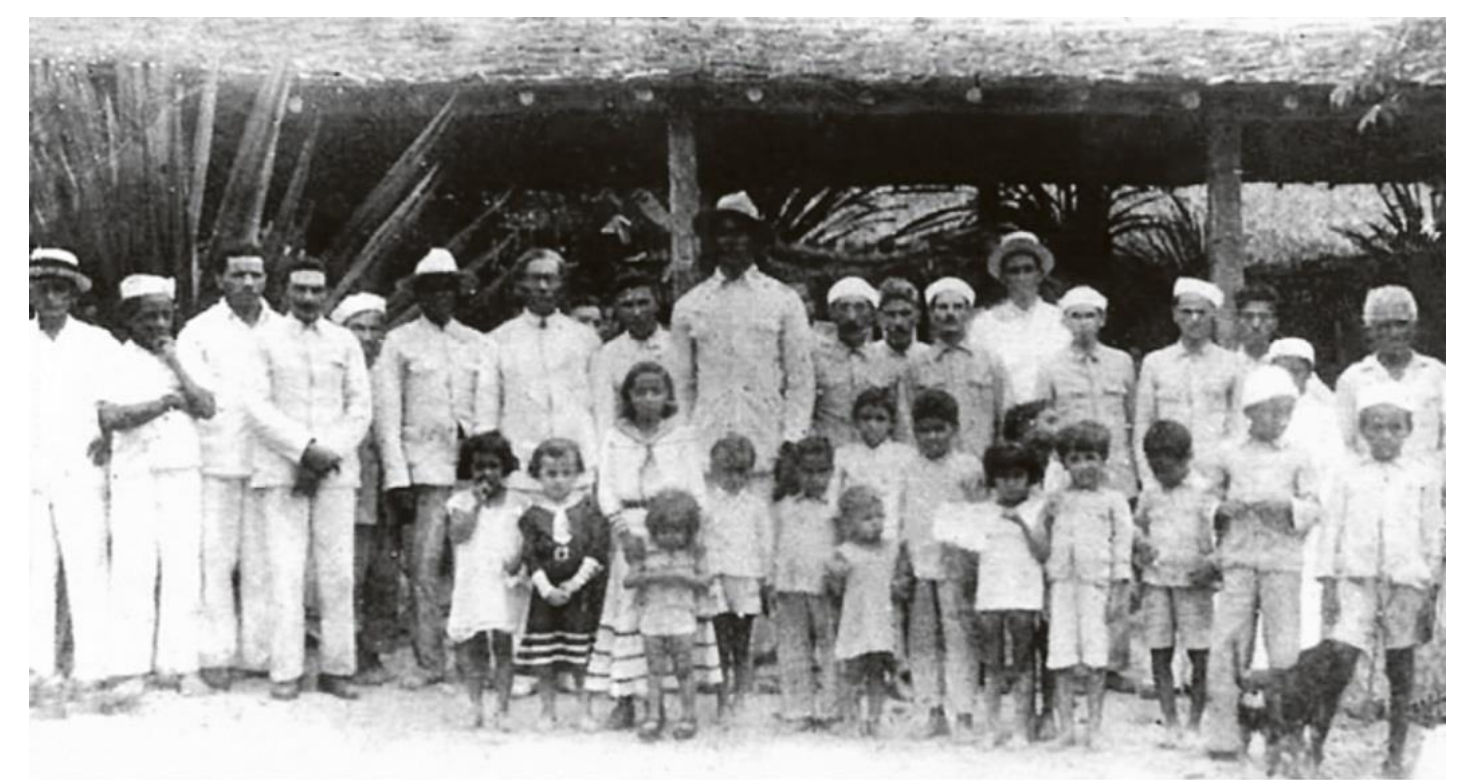

Foto 4 - Mestre Irineu no centro de chapéu, reunido com a irmandade. Nesta foto encontra-se Daniel Pereira de Mattos (o $7^{\circ}$ da esquerda para direita). Fonte: Internet

\subsection{Mestre Daniel e o prenúncio de sua missão religiosa}

Antes da fundação de sua missão religiosa em 1945, Mestre Daniel teria tido experiências místicas transcendentais, que representariam o prenúncio de sua jornada espiritual. São vários os relatos que abordam estes acontecimentos. Em entrevista com dona Chica Gabriel, líder de uma das igrejas da Barquinha, o Centro Espírita Obras de Caridade Príncipe Espadarte, obtive o seguinte relato:

(...) sobre uma visão que ele teve justamente a história da visão... que ele dormiu na praia né... e nessa visão foi que ele viu... chegar... um navio muito bonito, todo branquinho, a tripulação tudo vestido de branco... aí quando pegaram ele, levantaram ele: "acorda Daniel!" E levaram ele naquela embarcação até... sei lá... e nessa viagem ele presenciou muita coisa, né... ele viu muita coisa... muita mesmo... aí... mostravam para ele: "Olha Daniel isso aqui é teu." Aí quando chegou... um lugar que tinha uma cadeira... um lugar bonito, aí: "senta Daniel, senta aí. Esta cadeira é tua". Aí ele disse que não... não sentou na cadeira, disse que não... não era digno de sentar naquela cadeira, que ele tava todo sujo... disse que não ia sentar: "então tá Daniel... tem razão". Aí pegaram ele, voltaram com ele de novo pelos mesmos... perambulando... voltando... levaram $e$ trouxeram e deixaram ele, também no mesmo lugar, aí foi quando ele acordou. Assim... foi cumpadi Zé Luis... quem contou isso aí pra mim ouvir.

Segundo dona Chica, "cumpadi Zé Luis" foi um membro antigo da missão que conviveu com Mestre Daniel. Na bibliografia consultada, encontrei outros depoimentos que indicam que, por meio destas visões, Daniel Pereira de Mattos teria recebido orientações espirituais para fundar uma doutrina religiosa. Mestre Irineu teria dado todo 
o apoio ao seu conterrâneo, inclusive, fornecendo daime para que Daniel iniciasse sua jornada missionária. No depoimento coletado por Goulart (2004) vê-se o seguinte:

(...) estas visões se repetiam com frequência para Daniel, sobretudo quando ele estava sob o efeito da bebida alcoólica. Mas ele só foi compreender o significado das mesmas através de suas experiências com o Daime. (...) quando Daniel se submeteu ao segundo tratamento para seu alcoolismo, com o Mestre Irineu, "dentro da luz do Daime", ele obteve uma "compreensão mais aberta, mais nítida daquelas visões. Ele resolveu, dentro desse segundo tratamento, tomar uma quantidade maior de Daime (...) Ele passou dois dias trabalhando, dois dias de miração lá no Alto Santo, com o Mestre Irineu (...) Ele queria esclarecer o que era aquela visão, aquela cena repetida na vida dele, de uma entidade mostrando para ele um livro azul (...) Foi, aí, nesse segundo tratamento, que ele teve uma compreensão mais clara, quando ele viu nitidamente a entidade lhe mostrando e lhe entregando o livro, dizendo que ali estava todo o significado de uma missão que ele haveria de cumprir sobre a Terra. A missão estava toda descrita naquele livro azul e, lá dentro do Alto Santo mesmo, ele começou a abrir o livro, a folhear, a descrever o que tinha nele. (p.117)

Ao que tudo indica, o livro azul que os seres espirituais teriam entregado ao Fundador representaria o conjunto de cânticos da Barquinha. Um livro em branco que, ao longo da trajetória desta missão religiosa, viria a ser preenchido por Mestre Daniel e seus seguidores com letras e versos melodiosos. Em campo, coletei informações mais detalhadas a respeito deste assunto, entretanto, exporei as reflexões pertinentes a este tema apenas no capítulo terceiro, considerando que o objetivo do presente capítulo é traçar um panorama geral que permita ao leitor conhecer o contexto e alguns fatos históricos importantes referentes ao objeto de estudo desta pesquisa.

\subsection{A capelinha de São Francisco e os primórdios da Barquinha}

No ano de 1945, Mestre Daniel passou a residir em Vila Ivonete, uma região remota da cidade de Rio Branco no Acre. Lá iniciou a sua jornada missionária, prestando caridade às pessoas que batiam à sua porta em busca de ajuda. Eram caçadores, seringueiros, viajantes, crianças e todo tipo de gente que ouviam falar da sua fama de bom rezador e curador. Construiu uma capelinha de taipa e palha em homenagem a quem ele considerava o mentor de sua missão: São Francisco das Chagas (São Francisco de Assis).

Ele começou a rezar nessas pessoas, para tirar panema dos caçadores e nas crianças que vinham com quebranto (...) com o tempo, a fama de Daniel, de bom rezador, se espalhou. Muitos não retornavam, mas houve os que ficaram. O seu primeiro seguidor foi José Joaquim, que depois receberia a designação de "frei". Mais tarde, chegariam 
Augustinho Henrique Paiva, Elias Côrrea, Anelino, formando um conjunto de quatro membros da "Capelinha de São Francisco", dirigida pelo Mestre Daniel. (...) Com o auxílio da rabeca dele, do seu violino, ele foi acertando as melodias (...) Conforme ele ia recebendo o hinário, os irmãos iam chegando". (...) As rezas, o Daime, os hinos faziam com que cada vez mais pessoas procurassem Daniel para serem "curadas". Como disse o próprio Antônio Geraldo numa outra ocasião, "o pessoal foi dizendo que em tal parte tinha um velhinho, assim preto, que rezava em criança muito bem (...), tocando aqueles hinos bonitos". Desta forma, "foi aprovado o serviço dele, e ele curou muita gente". (Goulart, 2004, p. $119-120$ )

Conforme os relatos obtidos, com o passar do tempo a comunidade foi se estruturando e crescendo em número de adeptos. O incipiente segmento religioso começou a ganhar fama na cidade, ainda que a missão tenha sofrido preconceito e perseguição por parte da sociedade. Ao longo dos anos, Daniel e seus seguidores foram recebendo os hinos que expressam no conteúdo de suas mensagens esse sentimento de alguém sendo oprimido por outrem, como no caso do hino que colocamos a seguir:

\section{O Poder da Luz do Daime}
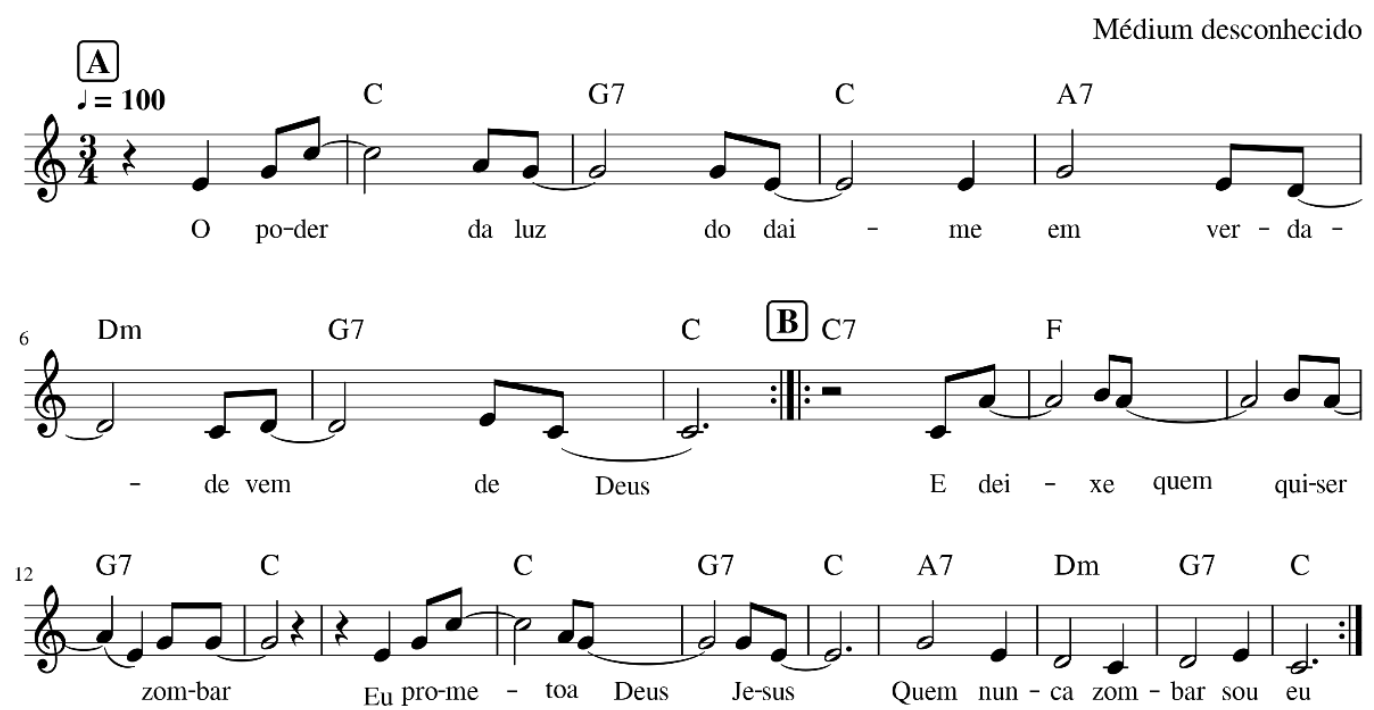

$(\text { Partitura } 1)^{20}$

O poder da luz do daime, em verdade vem de Deus (Bis)

E deixem os profanos zombarem

Eu prometo a meu Jesus

Quem nunca zombar sou eu

\section{Bis}

\footnotetext{
${ }^{20} \mathrm{Na}$ transcrição, resolvi colocar o nome do médium que recebeu o hino, entretanto, em alguns casos, tive dificuldades para reconhecer o médium que canalizou a mensagem.
} 
Nesta luz se vê verdades, quem nos mostra é o Criador (Bis)

Santos mistérios de luz $\left.\begin{array}{c}\text { Aonde Deus derrama as graças } \\ \text { Para quem tem fé e amor }\end{array}\right\}$ Bis

Meus irmãos vamos rezar, e adorar o Criador (Bis)

$$
\left.\begin{array}{c}
\text { E deixem quem quiser zombar } \\
\text { Quem zombar é para Deus } \\
\text { Igual Judas traidor }
\end{array}\right\} \text { Bis }
$$

A luz do daime é tão fina, que parece a luz do dia (Bis)

$$
\left.\begin{array}{c}
\text { Vem do olhar de doçura } \\
\text { De Deus Nosso Senhor } \\
\text { E da Sempre Virgem Maria. }
\end{array}\right\} \text { Bis }
$$

Daniel Pereira de Mattos faleceu em 08 de setembro de 1958. Conta-se que, em virtude da morte do líder espiritual, a comunidade formada por seus inúmeros seguidores passou por momentos difíceis de dúvidas e incertezas com relação ao futuro do grupo, no entanto, decidiram dar continuidade ao trabalho missionário de seu Mestre.

\subsection{Dissidências e ramificações: As comunidades da Barquinha}

Por meio da bibliografia consultada, constata-se que o contexto histórico que engloba as comunidades ligadas à missão de Mestre Daniel é permeado por dissidências e ramificações. Usarei aqui, de um lado, o termo dissidências para fazer referência aos grupos que se formaram em razão de algum tipo de conflito ideológico que terminou por desencadear o rompimento entre os seus membros e, por outro, o termo ramificações para me referir às comunidades que se originaram "amigavelmente" como forma de estender os trabalhos espirituais de um determinado Centro para outras localidades. A seguir, exponho um resumo dos principais fatos históricos concernentes a este fenômeno social. 


\subsubsection{Centro Espírita e Culto de Oração Casa de Jesus Fonte de Luz (CECOCJFL) ${ }^{21}$}

Em 20 de janeiro de 1959, Antônio Geraldo da Silva ou Mestre Antônio Geraldo ou Mestre Conselheiro, como também era conhecido, assumiu a liderança da comunidade. Nesse período, foi instituído o que seria o primeiro Centro ligado a Barquinha. Segundo Goulart (2004):

(...) teve o início da formulação do primeiro Estatuto. A capela onde funcionavam os trabalhos foi aos poucos sendo ampliada, foi iniciada a construção do cruzeiro e da escola São Francisco de Assis. O novo líder também recebeu instruções, nos trabalhos com a Santa Luz (o daime) sobre o fardamento (com sua respectiva simbologia), sobre o bailado do parque, o Batismo das crianças e também sobre o aperfeiçoamento dos trabalhos de obras de caridade. ${ }^{22}$

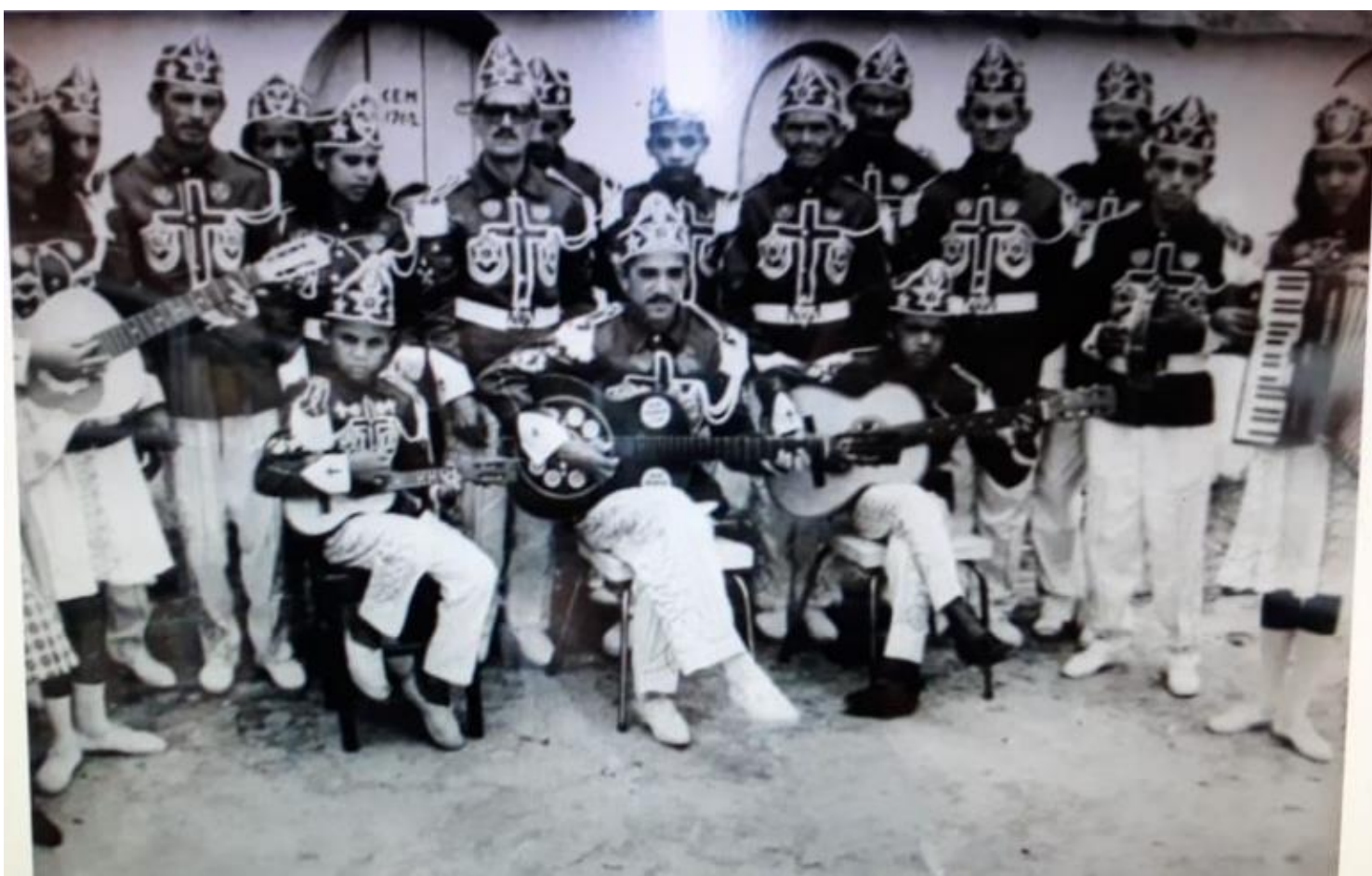

Foto 5 - Irmandade do CECOCJFL. No centro, com o violão está o Mestre Antônio Geraldo, à sua direita, em pé, o então vice-presidente do Centro, Manoel Hipólito de Araújo. Fonte: (MAGALHÃES, 2013)

A comunidade decidiu que Mestre Antônio Geraldo presidiria o Centro num período de dez anos. Após esse período, um novo pleito deveria ser realizado para se escolher um novo presidente ou reeleger o dirigente vigente. Ao fim da primeira década

\footnotetext{
${ }^{21}$ Por questões metodológicas, usarei daqui por diante as siglas dos Centros ligados à Barquinha para me referir aos mesmos.

${ }^{22}$ Informações coletadas no livreto intitulado Antônio Geraldo: o Marinheiro de luz, publicado em 2007 em homenagem ao mestre Antônio Geraldo por ocasião do $7^{\circ}$ ano de seu desencarne. Texto de Aretuza Bandeira de Araújo Batista.
} 
(1969), Mestre Conselheiro foi reeleito por mais 10 anos à frente da irmandade. Entretanto, conflitos internos o levariam a se desligar do grupo em 1977.

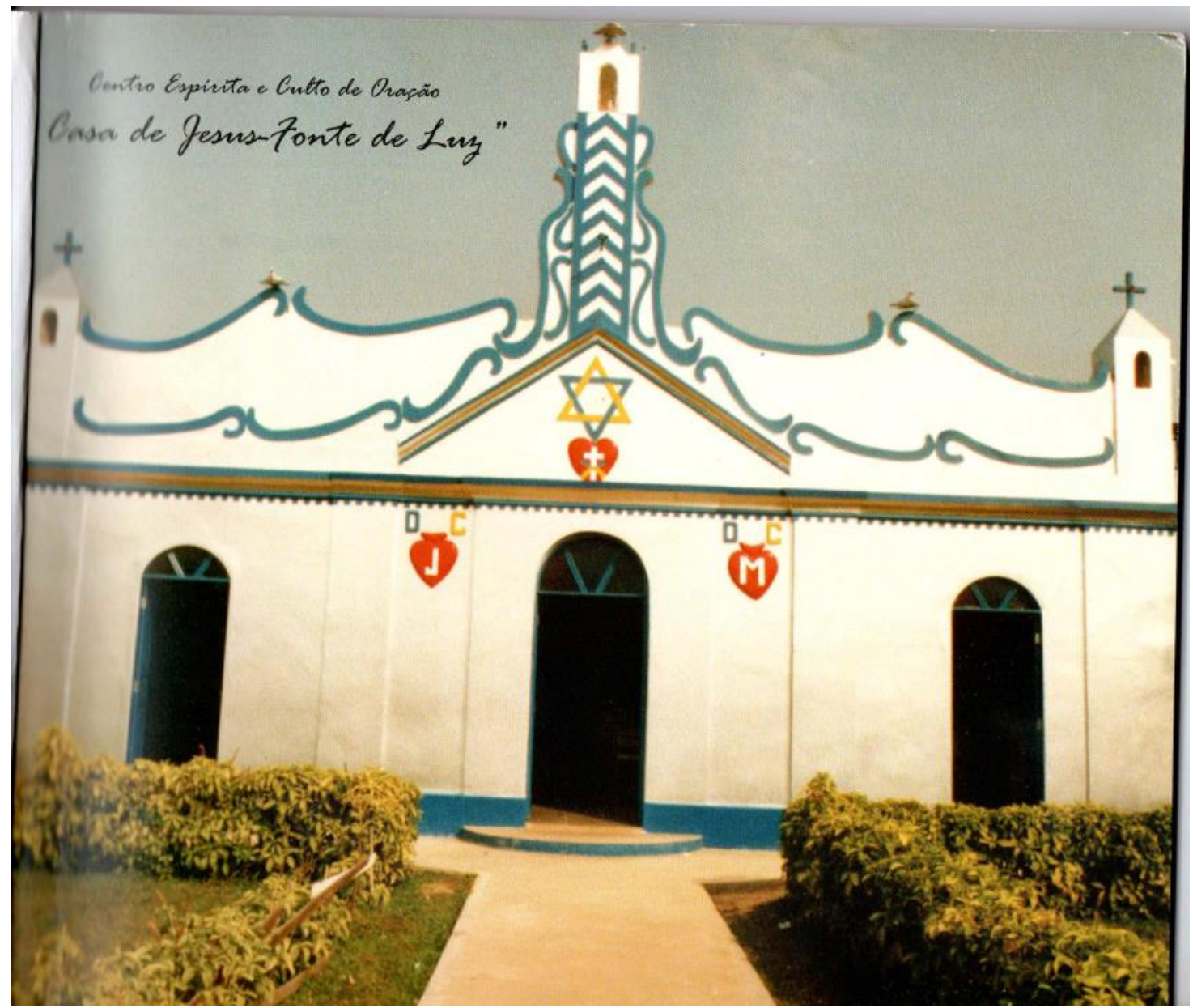

Foto 6 - Fachada do templo do CECOCJFL. Fonte: (MARGARIDO \& ARAÚJO NETO, 2005)

Com a saída de Mestre Antônio Geraldo, o então Vice-Presidente do Centro, Manoel Araújo, assumiu a presidência do CECOCJFL. Manoel Hipólito de Araújo nasceu em 10 de junho de 1921 no seringal Aquidabã, município de Eirunepé (AM). Tendo falecido em 17 de agosto do ano de 2000, a presidência do Centro foi ocupada por seu filho, Francisco Hipólito de Araújo Neto, o qual permanece no cargo até os dias atuais.

Por meio da bibliografia consultada, foi possível identificar a existência de outras comunidades consideradas como "extensões" do trabalho do CECOCJFL (ramificações), de acordo com Magalhães (2013):

Em fins da década de 90, ações rituais regulares vinculadas ao Centro Espírita e Culto de Oração "Casa de Jesus - Fonte de Luz" estabeleceram-se no estado de Rondônia. Na cidade de Ji-Paraná, e na capital do estado do Rio de Janeiro. Atualmente, a Casa de Mestre Daniel de Ji-Paraná, dirigida por Fernando, segue independente. No 
Rio de Janeiro, persiste a ligação de um grupo de adeptos com a matriz. Contudo, recentemente, um de seus membros constituiu de forma autônoma nesta mesma cidade outra Casa de Mestre Daniel, denominada Centro Espírita e Casa de Oração Barquinho de Luz. Em concomitância com a sede no Rio de Janeiro surgiu a sua filial em Campina Grande, Paraíba.

Uma série de comunidades dissidentes surgiram a partir do CECOCJFL, como está colocado a seguir.

\subsubsection{Centro Espírita Luz, Amor e Caridade (CELAC)}

De acordo com as informações conseguidas em campo, no ano de 1961 ocorre a primeira dissidência no CECOCJFL. Na ocasião, uma médium da casa, Maria Baiana e seu esposo Juarez se desligaram do centro para fundar em 1967 o CELAC.

Juarez Martins Xavier nasceu em 17 de dezembro de 1924 na cidade Capim Grosso (CE). Maria Rosa de Almeida nasceu em Jacobina (BA), infelizmente não encontrei na bibliografia consultada as datas do seu nascimento e de seu falecimento. Numa entrevista concedida a Sandra Lucia Goulart (2004), a própria médium relata como se deu o seu afastamento do CECOCJFL:

Assim, a senhora Maria Rosa destacou que "sentia muita necessidade de ter um lugar, um espaço, onde pudesse aparelhar" da maneira dela, "com liberdade". O termo "aparelhar" é utilizado com frequência por esses religiosos para indicar o momento em que um médium incorpora seus "guias", isto é, os seres espirituais com os quais ele trabalha regularmente. A argumentação de Maria Rosa mostra que, muito provavelmente, o tipo de incorporação vivenciado por ela destoava dos padrões de transe do centro de Antônio Geraldo. Talvez este seja, aliás, um dos principais motivos do seu rompimento com o mesmo. Numa entrevista que realizei com Antônio Geraldo, ele demonstrou uma visão similar, afirmando que Maria Rosa e Juarez tinham um "trabalho próprio, que dava abertura para outro tipo de atuação das entidades (p. 138)

O Senhor Juarez faleceu em 04 de fevereiro de 2015. Em campo, notei que o CELAC é uma comunidade pequena e modesta, cuja sede fica no bairro do Amapá, zona rural da capital Rio Branco no Acre. Não há registro na bibliografia consultada de novas dissidências ou ramificações ligadas a este grupo religioso. 


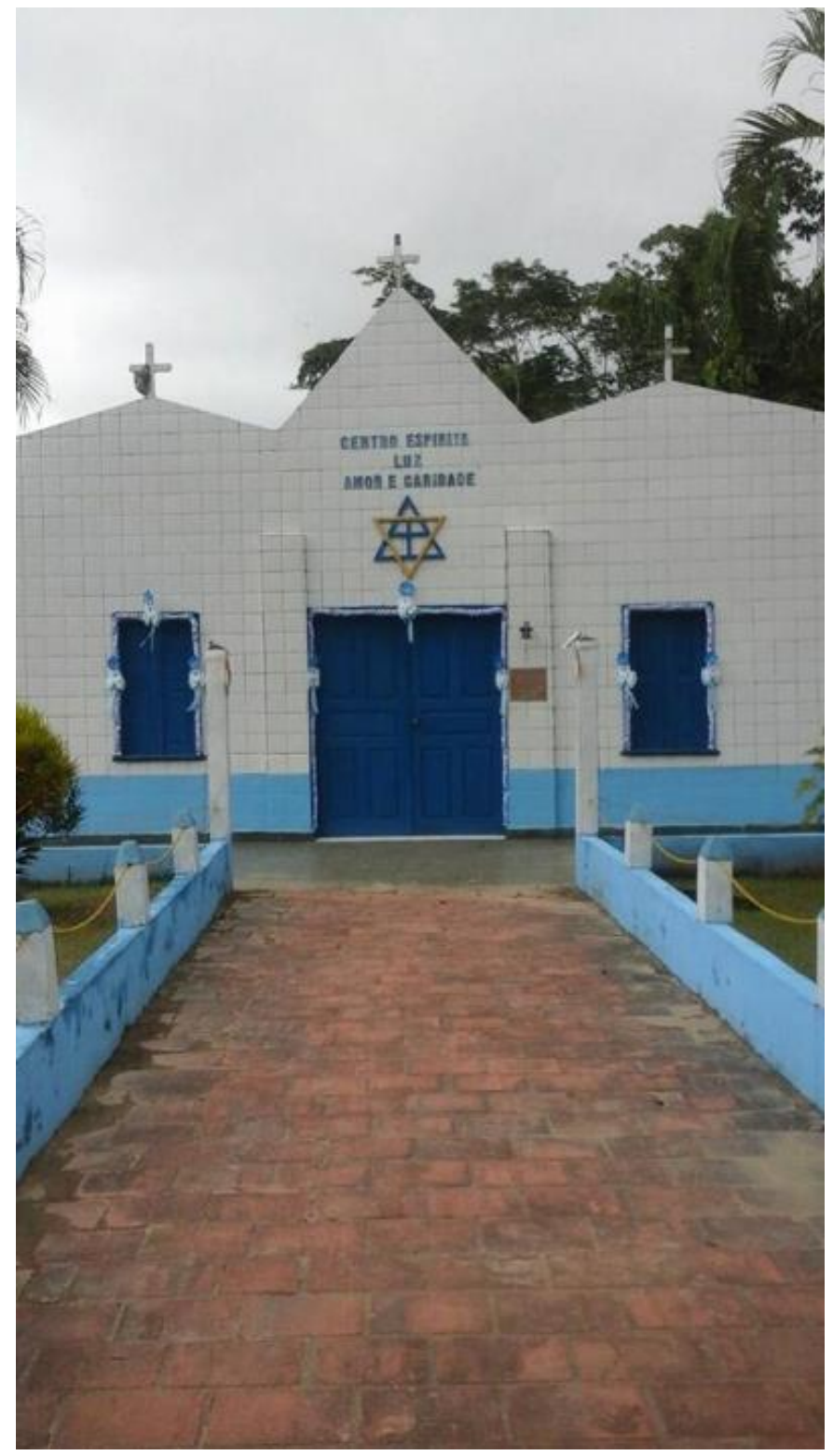

Foto 7 - Fachada do templo do CELAC. Fonte: Internet

\subsubsection{Centro Espírita Daniel Pereira de Matos (CEDPM)}

Em 20 de janeiro de 1979, Mestre Antônio Geraldo, que havia se desligado do CECOCJFL, funda seu novo Centro numa localidade não muito distante dali. Antônio Geraldo da Silva nasceu, em 25 de maio de 1922, na cidade de União (CE). Mestre Conselheiro era músico e recebeu muitos hinos, salmos e pontos, deixando um grande legado musical para a missão fundada por Mestre Daniel. De acordo com as informações colhidas em campo, somente no CEDPM recebeu 320 hinos salmos e 720 hinos pontos, deixando além disso, 200 mensagens psicografadas que são utilizadas nos rituais litúrgicos do Centro. 


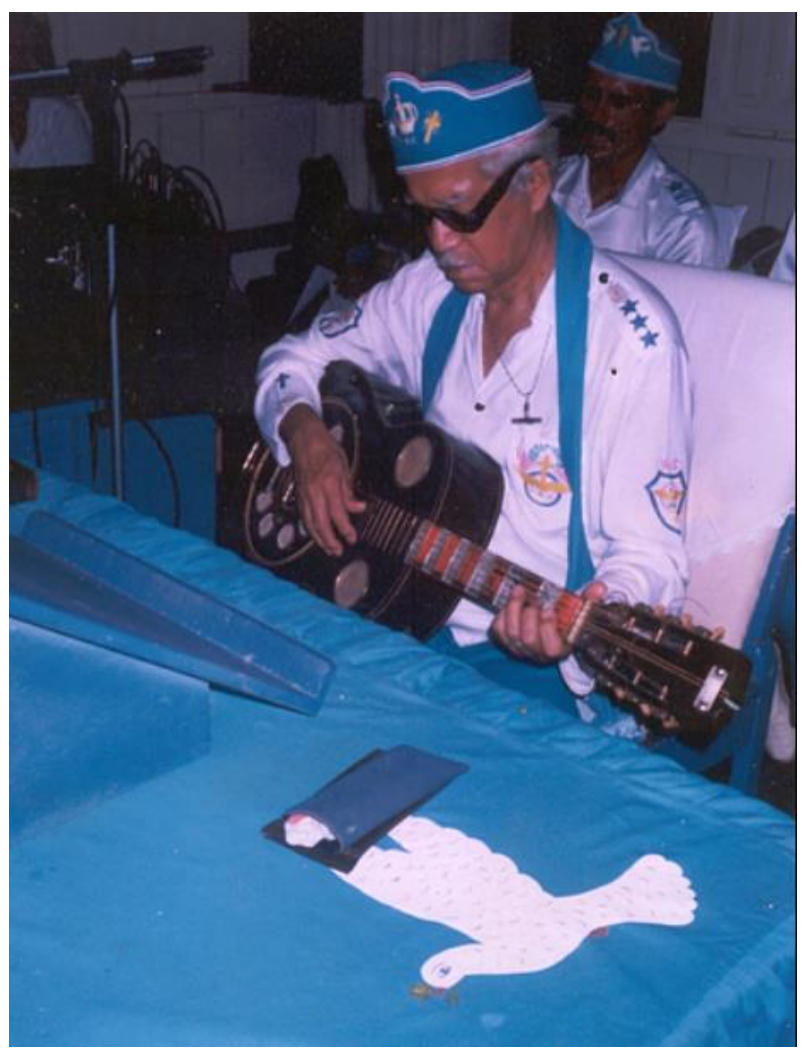

Foto 8 - Mestre Antônio Geraldo tocando o seu violão num dia de culto no CEDPM. Fonte: https://barquinhosantacruz.wixsite.com/cedpm

Mestre Antônio Geraldo faleceu em 28 de julho de 2000. Nesta época, seu filho Antônio Geraldo da Silva Filho, atual Presidente do CEDPM, assumiu a liderança da comunidade.

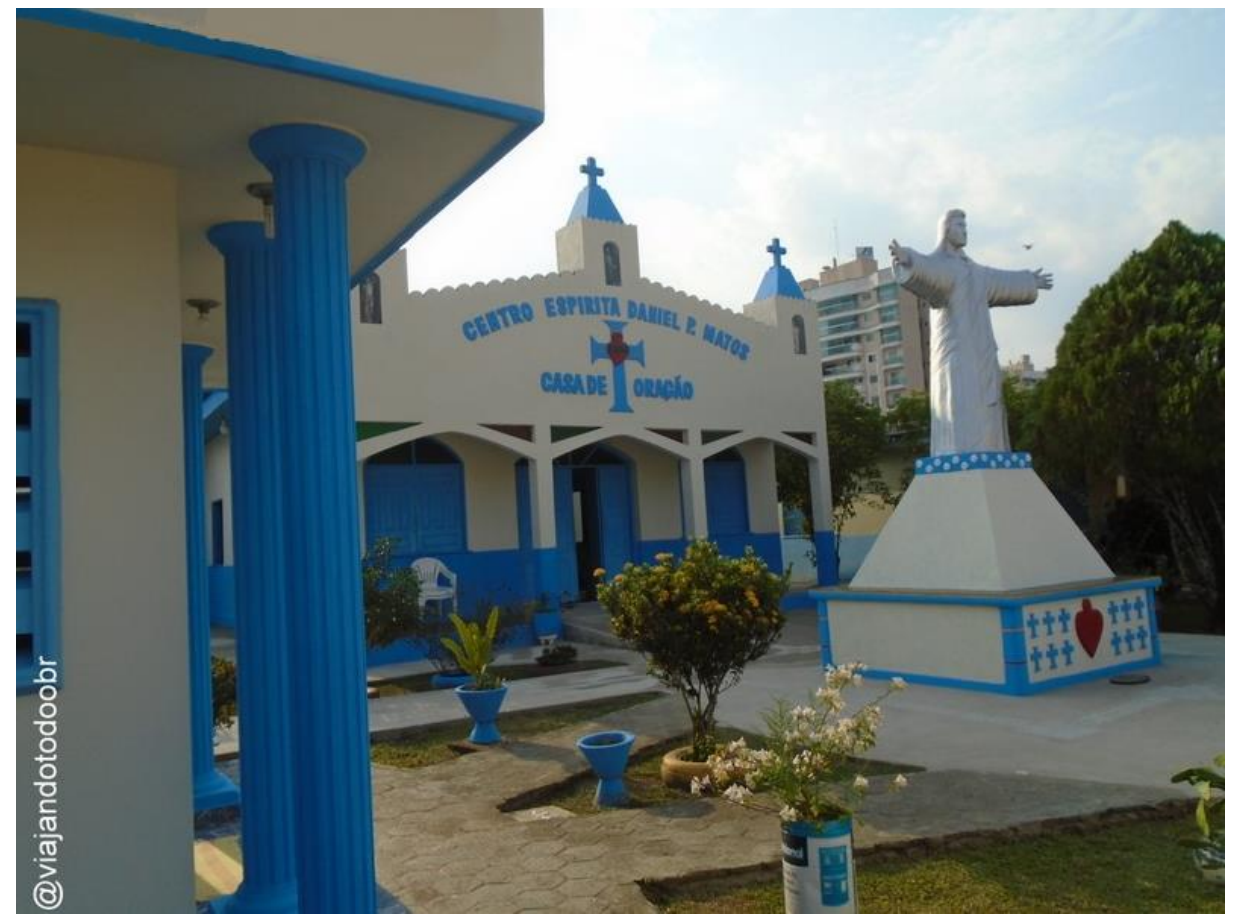

Foto 9 - Fachada do templo no Centro Espírita Daniel Pereira de Matos. Fonte: Internet 
Do CEDPM surgiram outras comunidades: o Centro Espírita São Francisco de Assis (ramificação), localizado no município de Plácido de Castro no Acre; o Centro Espirito Santo Inácio de Loyola (dissidência), além de uma comunidade que foi fundada em Brasília-DF, porém, de acordo com as informações levantadas, esta comunidade não existe mais.

\subsubsection{Centro Espírita Obras de Caridade Príncipe Espadarte (CEOCPE)}

Francisca Campos do Nascimento, também conhecida como Chica Gabriel e Irmã de Caridade, é a fundadora do CEOCPE, tendo permanecido por 34 anos no CECOCJFL. Dona Chica Gabriel foi um dos primeiros aparelhos habilitados para incorporar as entidades e prestar obras de caridade na missão. Trabalhou como costureira, costurando e bordando as fardas dos membros oficiais. Realizava o catecismo com as crianças aos domingos. Confeccionava o andor das romarias e também as lembrancinhas, comumente distribuídas em datas festivas. Além disso, recebeu muitos hinos, salmos e pontos e também trabalhou algum tempo cantando dentro dos cultos e bailados. No ano de 1991, em meio a conflitos internos, se desligou do CECOCJFL.

No início, Dona Chica Gabriel relutou um pouco com a ideia de criar um novo Centro, porém, foi incentivada por um grupo de pessoas que se uniram a ela para fundar um novo agrupamento da missão de Mestre Daniel. Eram simpatizantes de seu trabalho, clientes de suas entidades, além de seus próprios familiares. Na época, seu esposo, Francisco Gabriel, também conhecido Padrinho Chico, cedeu um casebre de madeira bem simples, que fez para guardar suas ferramentas, para que dona Chica pudesse trabalhar no local; foi lá que ela deu início aos trabalhos de orações e atendimento com as entidades. ${ }^{23}$

\footnotetext{
23 Este casebre até hoje existe, ele faz parte do patrimônio histórico do Centro, e é chamado de "Casinha
} do Pai Vicentino" em homenagem a uma das entidades de dona Chica Gabriel. 


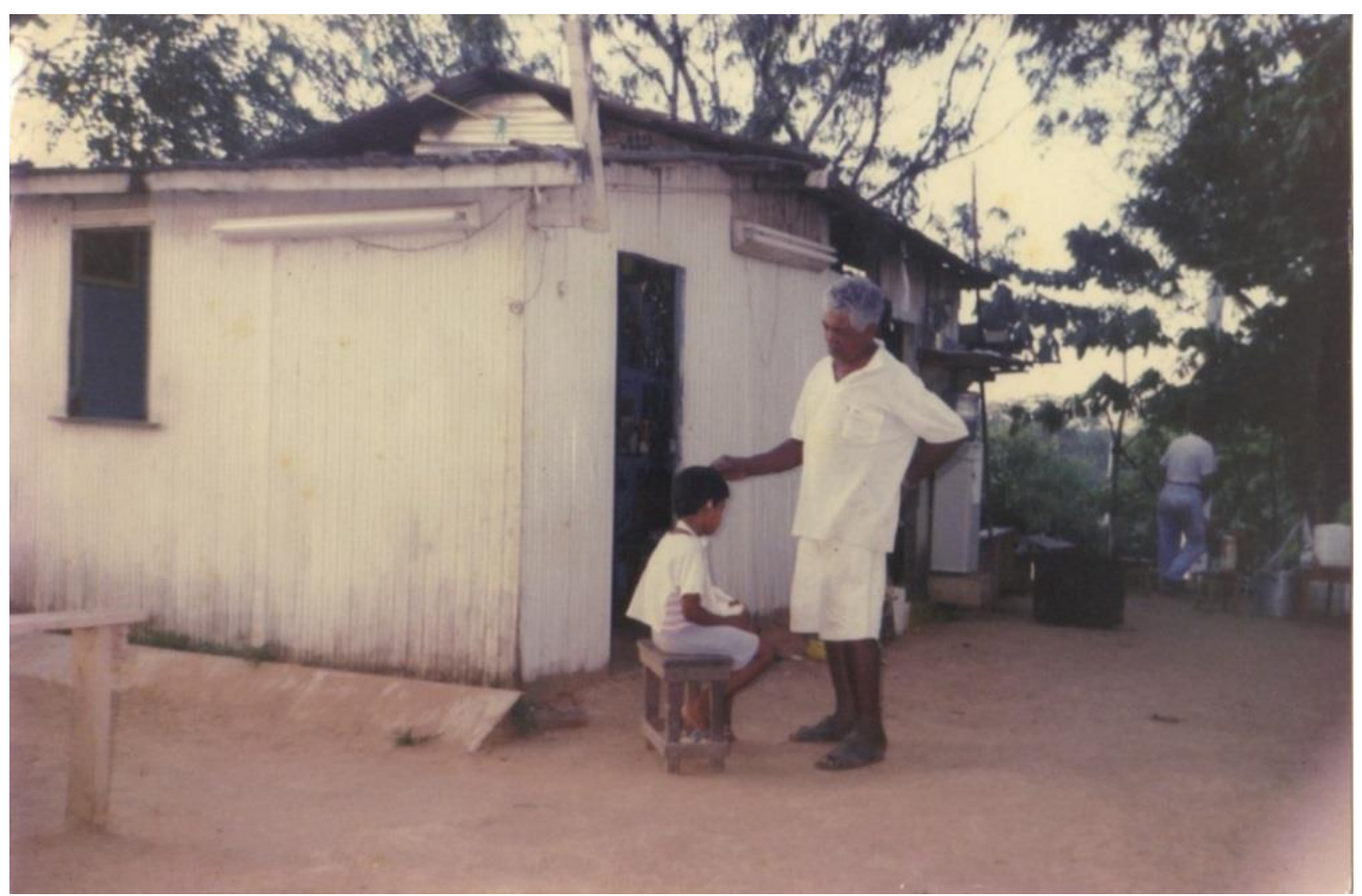

Foto 10 - Padrinho Chico rezando em criança ao lado da "Casinha do Pai Vicentino" na década de 90. Fonte: Acervo CEOCPE

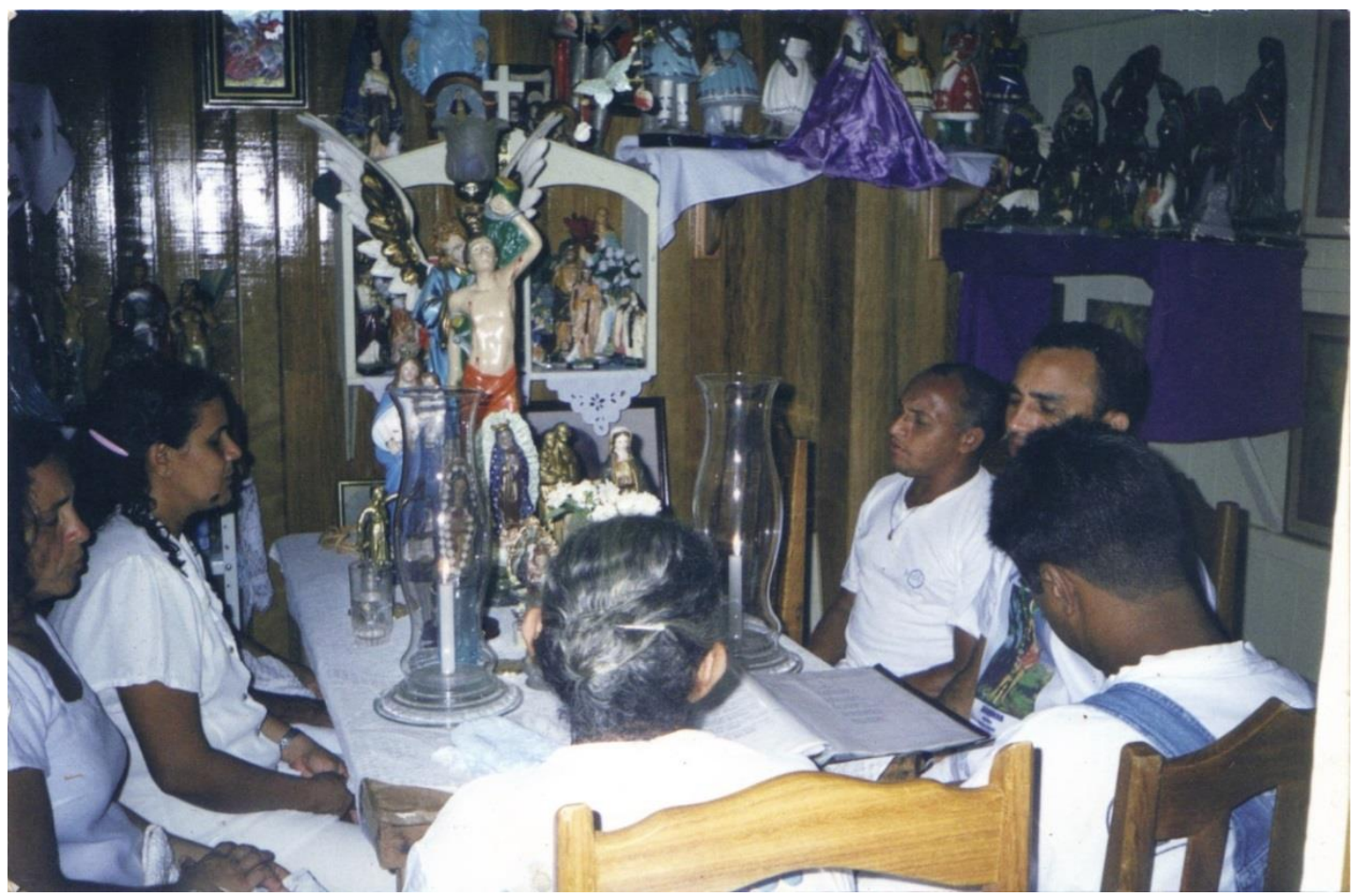

Foto 11 - Um dia de culto no interior da "Casinha do Pai Vicentino" no início da década de 90. Fonte: Acervo CEOCPE

O nome do Centro é uma homenagem ao guia espiritual que acompanha Dona Chica Gabriel desde os primórdios de sua trajetória dentro da missão: O Príncipe 
Espadarte do Mar, também conhecido como Soldado Guerreiro Príncipe Dom Simeão, e também como Soldado Guerreiro Príncipe da Paz.

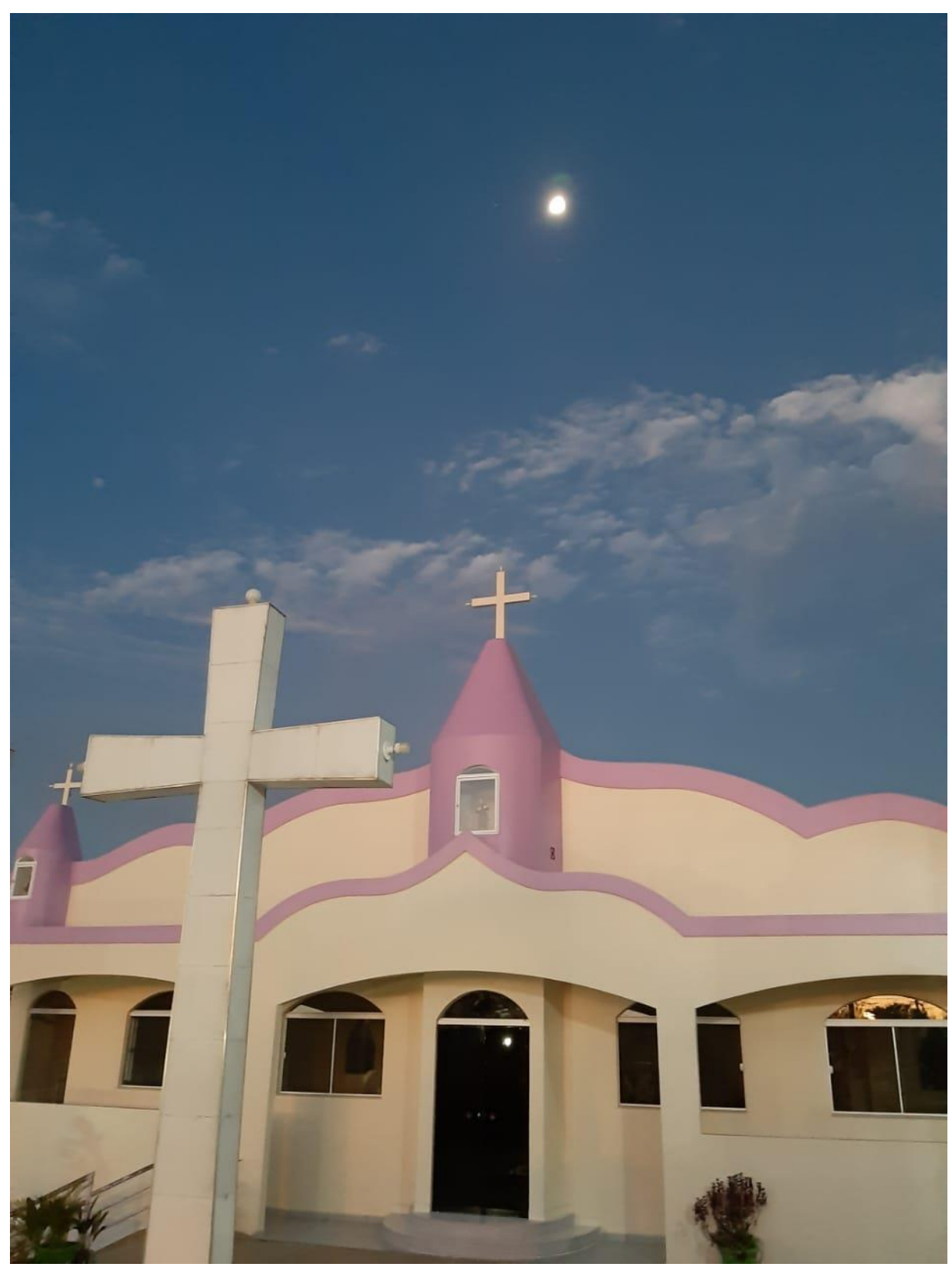

Foto 12 - Fachada do templo do CEOCPE, 2019. Fonte: Acervo CEOCPE

A comunidade cresceu e se expandiu. Hoje existem quatro filiais do Centro Espírita Obras de Caridade Espadarte, uma no Belo Jardim (bairro situado na zona rural de Rio Branco), outras em Niterói-RJ, Brasília-DF e São Paulo-SP. Além dessas, obtivemos informações que indicaram a existência de uma comunidade dissidente do CEOCPE em Rio Branco no Acre, o Centro Espírita Nossa Senhora da Rosa Mística. 


\subsubsection{Outras comunidades}

A bibliografia consultada aponta a existência de mais um Centro dissidente do CECOCFL. Não conseguimos muitas informações sobre este Centro, segundo Santos (2017) o senhor José do Carmo Ferreira Lima:

Fundada então, no ano de 1996, sua própria missão na região central de Rio Branco, com uma extensão em Porto Acre, município a nordeste de Rio Branco, aproximadamente a uma hora da capital, chamando-a de Centro Espírita de Obras de Caridade Raios de Luz Nossa Senhora Aparecida. (p. 81)

Como se vê, são inúmeras comunidades que, de uma forma ou de outra, têm ligação com a missão fundada por Daniel Pereira de Mattos. Durante a investigação identifiquei a ocorrência de outros grupos menores além destes citados aqui. Observa-se portanto, nesta longa trajetória, o mesmo fato recorrente na própria história da humanidade: o inevitável processo de expansão e dissidências com o passar do tempo, no interior de inúmeras religiões.

A questão revela um problema conceitual desta pesquisa, afinal de contas, o que é a Barquinha de fato? Quais são os limites que demarcam o território daquilo que está sendo chamado de Barquinha aqui? Durante o trabalho de campo, notei que este é um tema polêmico, repleto de opiniões, muitas vezes, discordantes entre os membros dos diversos Centros da Barquinha. Muitos questionam acerca da legitimidade de grupos dissidentes que vão se formando ao longo do tempo.

Esta pesquisa não tem a finalidade de solucionar a problemática citada acima, em busca de uma definição concreta daquilo que deve ser os limites conceituais em torno do objeto de estudo. Trata-se de uma questão complexa que, por si só, pode ser tomada como tema de outros trabalhos. O fato é que a Barquinha não se refere a um grupo (Centro) institucionalizado e fácil de ser reconhecido, mas de uma forma abstrata de se fazer referência à tradição religiosa fundada por Mestre Daniel. Uma semente plantada e cultivada por 12 anos metaforicamente falando. Do broto semeado, cresceu a árvore que se desenvolveu ao longo dos anos, gerando os seus frutos. 


\section{Capítulo 3 - A Música da Barquinha}

Adiante, exponho primeiramente algumas reflexões sobre funções da música no contexto da Barquinha, conforme identificado na investigação. Em seguida, faço uma abordagem sobre algumas características desta expressão artística tão relevante para esta tradição religiosa por meio da análise musical. Este capítulo tem o objetivo de apresentar ao leitor o resultado dos esforços empregados em campo na tentativa de descrever, em poucos parágrafos, aspectos gerais desse universo musical.

\section{1 "Funções" e "usos" da música na (da) Barquinha}

A música é um elemento de fundamental importância na missão de Mestre Daniel. Através dela esta tradição religiosa se desenvolve, criando-se e recriando-se ao longo do tempo. Em todos os Centros, visitados durante o trabalho de campo, constatei que a maioria dos rituais é permeado por música. Por meio dos cânticos executados durante os cultos, a doutrina da igreja é transmitida aos adeptos ao longo do calendário ritualístico.

\subsubsection{A função de expressão emocional.}

Em geral, nos mais diversos contextos sociais, o homem vem utilizando a música como um veículo para expressar ideias e sentimentos. Em seus estudos, Alan Merriam (1964) encontra evidências consideráveis que indicam que a música pode funcionar como meio de expressão emocional. Citando um dentre os vários trabalhos de Burrows, no qual este autor descreve uma série de "funções" da música dos Tuamotus ${ }^{24}$, Merriam, expõe um excerto no qual Burrows enfatiza a importância da música no sentido de:

Estimular e expressar emoções nos performers e transmiti-las aos ouvintes. A emoção pode ser a exaltação religiosa, como no canto da criação e no canto do sagrado pássaro vermelho; pesar, como nos lamentos; saudade ou paixão, como nas canções de amor; alegria em movimento; (...) e uma variedade de outras emoções nas danças; exaltação do ego em cânticos de glória; despertando para uma nova coragem e vigor, como nos cantos animadores; e sem dúvida outros ... Subjacente a tudo isso, em maior ou menor grau, está a função geral de estimular, expressar e compartilhar emoções. Esta função está envolvida mesmo nas canções de trabalho. De acordo com o modo de

\footnotetext{
${ }^{24}$ Trata-se de um povo que habita no Arquipélago Tuamotu ou Ilhas Tuamotu na Polinésia francesa, localizado no sul do Oceano Pacífico.
} 
pensar nativo, algo mais do que emoção - a saber, magia ou poder sobrenatural - é transmitido nos encantamentos; mas, do ponto de vista europeu, a função efetivamente desempenhada ainda é a de transmitir emoção. ${ }^{25}$ (1933: 54-56)

Dentro do universo das religiões ayahuasqueiras, é possível observar claramente esta função destacada por Merriam. Beatriz Caiuby Leite e Gustavo Pacheco (2009) desenvolveram uma pesquisa abordando dois segmentos religiosos oriundos da região amazônica, o Santo Daime e a União do Vegetal (UDV), descrevendo as relações destes grupos com a música. É notória a importância que a música exerce dentro destes rituais.

O papel preponderante que a música ocupa no cotidiano destas religiões, na produção dos significados religiosos e na construção do corpo e da subjetividade dos adeptos - como, por exemplo, pela intensificação de mirações, da eclosão de sentimentos diversos, como tristeza, êxtase e comunhão (...) (p. 18)

Devemos alargar nossa perspectiva para entender a música (...) como uma atividade ritual com especificidade própria e que em muitos momentos transcende o conteúdo verbal. Ao lado de seu aspecto de mensagem verbal, isto é, de enunciado do verbo divino, hinos e chamadas possuem também o importante papel de induzir, por meio dos sons, certos estados emocionais multissensoriais que permitem a transcendência da dimensão verbal da experiência espiritual. (p. 98)

Nestes excertos, os autores enfatizam a importância da música nestes rituais ayahuasqueiros, não somente como um veículo do conteúdo verbal contido nos cânticos (aspecto doutrinário), mas também como uma ferramenta que amplifica as experiências espirituais dos fiéis dentro dos cultos religiosos destas tradições. Na Barquinha não poderia ser diferente. A música tem papel fundamental na trajetória de seus membros dentro do segmento religioso, na medida em que ajuda a promover visões místicas (mirações), introspecções, aprendizados, curas, entre outras experiências, que muitas vezes marcam profundamente a vida das pessoas. Em campo, obtive muitos relatos que confirmam o que foi dito. Além disso, tive a oportunidade de tomar o daime, participar das sessões (outro modo como estas pessoas costumam denominar estes rituais) e

\footnotetext{
25 Stimulating and expressing emotion in the performers, and imparting it to the listeners. The emotion may be religious exaltation, as in the creation chant and song of the sacred red bird; grief, as in the laments; longing or passion, as in the love-songs; joy in motion; (...) and a variety of other emotions, in the dances; exaltation of the ego in chants of glory; stirring to new courage and vigor, as in the enlivening chants; and doubtless others. Underlying all of these in greater or less degree is the general function of stimulating, expressing, and sharing emotion. This function is involved even in the work songs. According to the native way of thinking, something more than emotion-namely, mana or supernatural power-is conveyed in the incantations; but from the European point of view the function actually performed is still of imparting emotion.
} 
vivenciar, na prática, tais experiências que esta tradição religiosa propicia para os seus membros.

É possível afirmar, consequentemente, que a música influencia diretamente no processo de criação de vínculos entre as pessoas e estas práticas religiosas. Muitos dos membros da Barquinha relataram que, inicialmente, começaram a frequentar os seus cultos pelo fato de terem apreciado a música local. Isto acontece, tanto com os músicos (performers), como com os demais membros (audiência) (SEEGER, 2004). Em campo, entrevistei alguns músicos da Barquinha. $\mathrm{O}$ trabalho que estas pessoas exercem é voluntário, ou seja, não recebem nenhum tipo de salário ou recompensação material no exercício de suas atividades como musicistas nestas comunidades. Os compromissos religiosos destes grupos ocupam mais da metade do calendário anual. Geralmente, uma sessão "comum" tem duração média de 3 horas. Datas festivas podem se estender por 12 horas, em um trabalho verdadeiramente extenuante.

Nas entrevistas, escolhi e apliquei algumas das questões sugeridas por Anthony Seeger (2004). Por exemplo, na pergunta direcionada ao músico Antônio (nome fictício): qual a razão que o levava a dedicar-se à função de músico na Barquinha? "Por que um indivíduo particular ou grupo social executa ou ouve os sons no lugar, no tempo e no contexto que eles(as) o fazem?(SEEGER, 2004, p.240). Neste questionamento obtive a seguinte resposta:

Bem, estou na Barquinha há mais de 15 anos... No início eu me encantei com aquelas mensagens bonitas, as valsas melodiosas e daí comecei a frequentar os trabalhos, pois gostava de ouvir os salmos. Depois, com o tempo fui chamado para tocar junto com os músicos... eu já tocava um pouco de violão na época. No fundo, no fundo eu gosto de tocar na igreja, me realizo com isso, apesar de ser um trabalho puxado. Tem épocas que é uma correria, nas romarias por exemplo, saio do trabalho as seis horas (18 horas), vou correndo pra casa, tomar banho se arrumar e correr pra igreja pra arrumar os equipamentos, dar uma passada no som e deixar tudo pronto pra começar a romaria às sete horas (19 horas). Imagine, fazer isso diariamente durante 34 dias seguidos como no caso da Romaria de São Francisco?! Mas, para mim é um privilégio poder fazer esse trabalho nesta casa de oração, pois amo fazer música, além disso, é dessa maneira que eu posso contribuir com as obras de caridade que prestamos aqui na igreja.

Devemos levar em consideração que, além da excessiva carga horária que os membros da Barquinha cumprem ao longo do calendário anual, todos possuem outros vínculos sociais, como trabalho, família, estudos, entre outros, de modo que precisam conciliar tudo isso com suas atividades religiosas. Tudo indica que existe um 
considerável esforço por parte destas pessoas para perseverarem no seguimento destes compromissos e, muitas vezes, a música é um elo importante neste contexto.

\subsubsection{As funções de validação das instituições sociais e rituais religiosos e contribuição para a continuidade e estabilidade da cultura.}

Se de alguma forma a música influencia a vida dos indivíduos da Barquinha, de um modo mais pungente, ela pode ser considerada como elemento estruturante desta tradição religiosa em si, ou seja, mais um papel da música que foi identificada no contexto da Barquinha. Com relação a este tipo de função que a música exerce nas diversas culturas humanas, diz Merriam:

Os sistemas religiosos são validados, como no folclore, por meio da recitação de mitos e lendas em canções, bem como por meio de músicas que expressam preceitos religiosos. As instituições sociais são validadas por meio de canções que enfatizam o que é adequado e impróprio na sociedade, bem como aquelas que dizem às pessoas o que fazer e como fazer. Essa função da música, entretanto, precisa ser mais estudada e expressa de forma mais concisa. (Tradução minha) ${ }^{26}$ (1964, p. $224-225)$

Analisando a trajetória histórica do CEOCPE, tem-se uma clara noção do que estamos sendo afirmado aqui. Em campo, observando a rotina deste Centro, constatei que o repertório executado na igreja está em constante transformação, pois com o passar do tempo os médiuns vão recebendo novos cânticos, novas mensagens, novas melodias que vão ampliando e constituindo o conjunto doutrinal da casa.

$\mathrm{O}$ primeiro salmo recebido no CEOCPE tem uma história interessante que exemplifica bem o que está sendo dito aqui. Em entrevista, Dona Chica Gabriel relatou como isso ocorreu:

Aquele hino da Virgem Mãe adorada... aquele hino não fui eu ... digamos assim ... que propriamente recebi, quem recebeu foi o Toinho. Agora só que ... ele não se lembrava da melodia ...aí ele disse que só... um pouquinho assim no coro né... Aí eu mandei que ele solfejasse... se lembrasse e tal né... aí ele disse: mãe a última estrofe a senhora que tem que compor, me disseram que a senhora quem tem... aí eu disse: "tá bom então vamos ver"... aí justamente é a última... foi eu que escrevi e digamos assim, depois né... aí veio a melodia...

\footnotetext{
26 Religious systems are validated, as in folklore, through the recitation of myth and legend in song, as well as through music which expresses religious precepts. Social institutions arc validated through songs which emphasize the proper and improper in society, as well as those which tell people what to do and how to do it. This function of music, however, needs to be further studied and more concisely expressed.
} 
aah!!... foi muito bom, foi logo nos primeiros dias que eu vim pra cá ... eu fiquei muito feliz.

Segundo Dona Chica Gabriel, este primeiro hino teria vindo para confirmar e testificar a sua missão, pois o desafio de estar à frente de um novo Centro da Barquinha gerou, naturalmente, tensão e dúvidas para ela e para o grupo incipiente. Isto foi crucial para o futuro da comunidade, na medida em que serviu de conforto e motivação para Dona Chica e seus seguidores perseverarem na continuidade do compromisso religioso. O hino foi recebido por Antônio Campos (Toinho), seu filho homem mais velho, sendo que a última estrofe foi recebida pela própria Irmã de Caridade. Segue abaixo um trecho do referido salmo:

\section{Uma Prova de Amor}

Recebido por: Antonio Campos do Nascimento e Francisca Campos do Nascimento

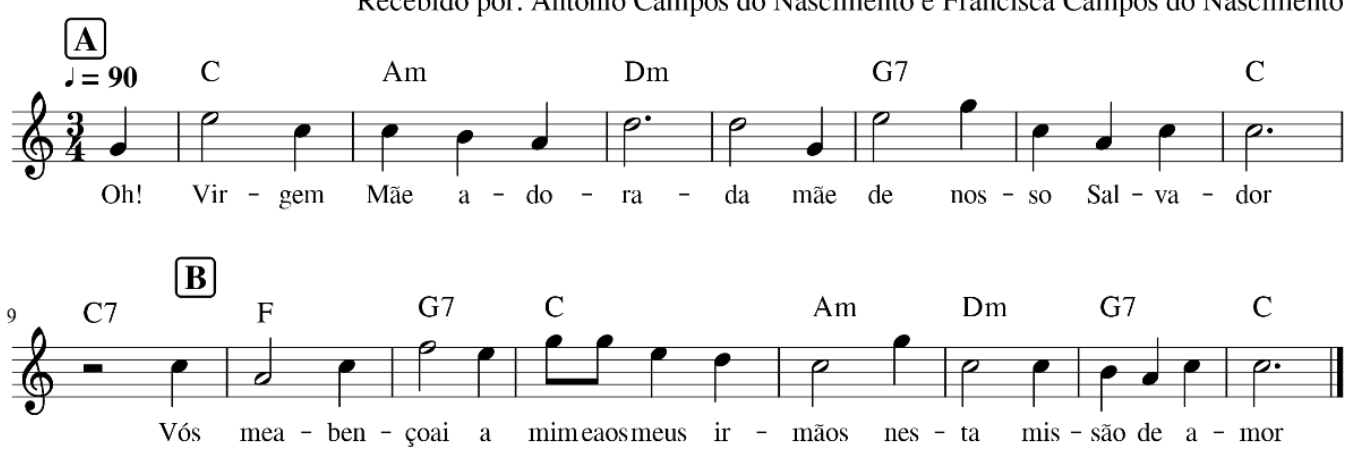

(Partitura 2)

Oh! Virgem Mãe adorada

Mãe de nosso Salvador

Vós me abençoais, a mim e aos meus irmãos

Nesta missão de amor

Hoje estou contrita

$\mathrm{Na}$ inspiração do amor

Me entrego junto com os meus irmãos

Pra continuar esta missão de amor

Minha caminhada é feliz

Para os pés do Salvador

A Virgem Mãe está à frente

Mãe de doçura e amor

Para mim não tem noite e nem dia

Nesta missão de amor

Para fazer a caridade

Em nome do Salvador 
Quem me deu este salmo bendito

Foi o Fundador para que eu afirmasse

Junto com os meus irmãos

Nesta missão de amor

Este salmo bendito

É uma prova de amor

De que estou com Deus

E estou com o fundador

Outro cântico que corrobora o que está sendo sustentando aqui é o hino intitulado "Uma eterna peregrinação", recebido por Alcimar Campos do Nascimento, filho de Dona Chica Gabriel e atual presidente do CEOCPE. Coloco a seguir um trecho do referido hino:

\section{Uma eterna peregrinação}

Recebido por Alcimar Campos do Nascimento
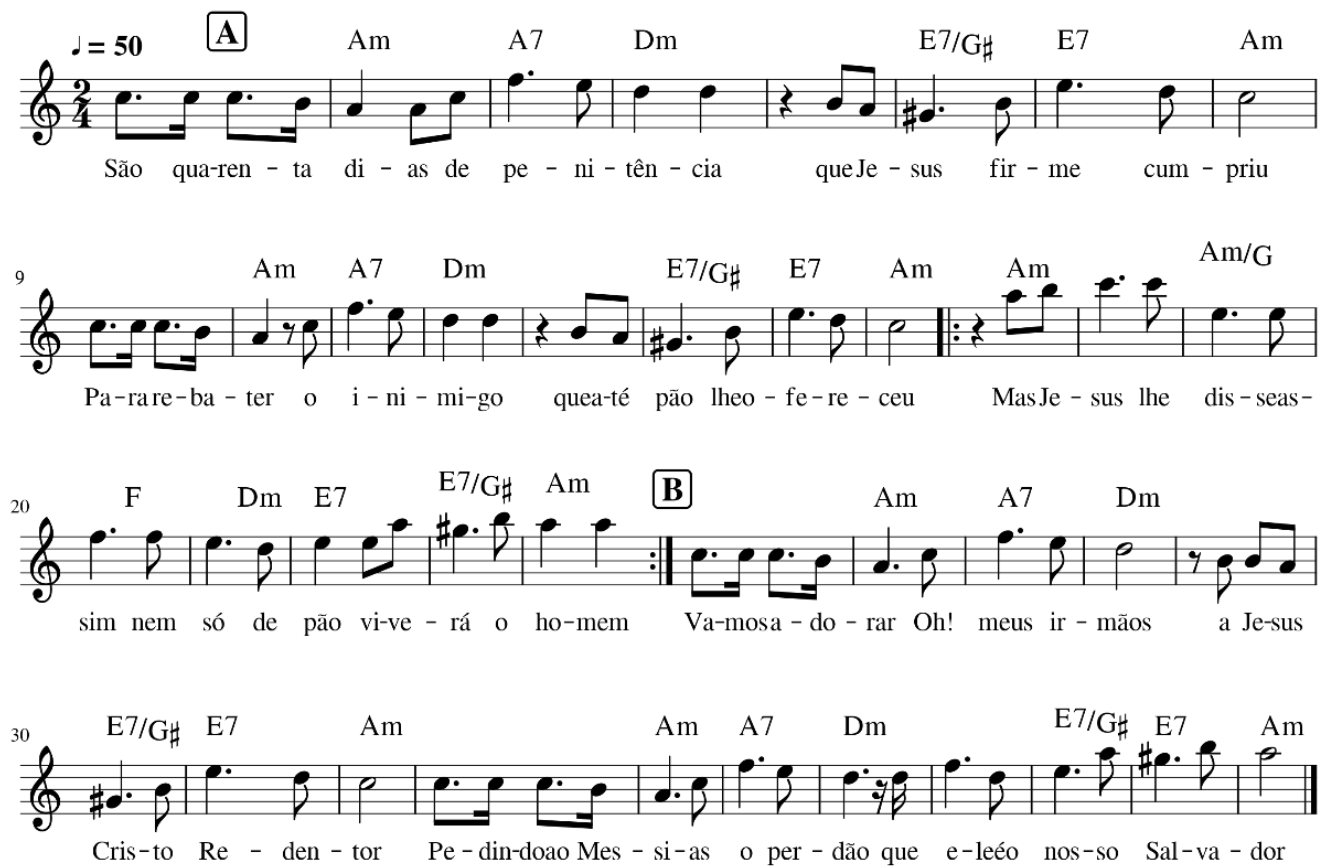

(Partitura 3)

São quarenta dias de penitência que Jesus firme cumpriu

Para rebater o inimigo que até pão lhe ofereceu

Mas, Jesus lhe disse assim:

Nem só de pão viverá o homem $\}$ Bis

Vamos adorar, Oh! Meus irmãos

A Jesus Cristo redentor

Pedindo ao Messias o perdão

Refrão

Que ele é o nosso salvador 
As palavras que vem do senhor é o que vai nos sustentar

Se tivermos a contrição de quem está a nos esperar

Com a força do amor supremo

Ao inimigo vamos expulsar

Bis

Depois de toda tentação que Jesus veio suportar

Tu vais embora Satanás, aqui não é o teu lugar

Está escrito em letras santas

Que só a Deus devo adorar $\}$ Bis

Segundo os relatos de Dona Chica Gabriel e seu filho Alcimar, a referida mensagem veio num momento em que a Irmã de Caridade estava com planos de implementar mais um novo compromisso no calendário da Casa, a quaresma. Os entrevistados disseram que o hino veio para confirmar e selar esta nova atividade na rotina de trabalhos do CEOCPE. Estas informações, obtidas em campo, reforçam a hipótese aqui posta: a música pode ser considerada um dos elementos que movimentam o processo de estruturação e validação da ritualística e da cosmologia da Barquinha.

\subsubsection{Rotina de atividades (Função litúrgica)}

A função mais evidente da música na Barquinha observada no trabalho de campo refere-se ao seu papel dentro de cada ritual. Praticamente, todas as atividades religiosas desenvolvidas nestas comunidades são constituídas de música. Por exemplo, a cerimônia de batismo de uma criança é composta por um culto dentro do templo, em que são cantados alguns hinos cuja temática é referente ao batismo, representando assim uma espécie de ato preparatório para a realização do batizado. Por sua vez, nos trabalhos de cura são cantados hinos de cura, nos trabalhos de instrução são executados hinos de instruções, e assim por diante.

Para uma melhor visualização disto, descrevo a seguir com mais detalhes a estrutura ritualística, ou seja, a rotina de trabalhos de uma das igrejas da Barquinha, o CEOCPE. Em campo, notei que este calendário foi e está sendo instituído ao longo da trajetória desta comunidade, conforme foi relatado pelos seus membros. Após a descrição de cada atividade, coloco um trecho de um hino que tem relação com o ritual em questão. Há que se deixar claro aqui que a rotina de trabalhos pode variar entre as igrejas da missão de Mestre Daniel, todavia pode-se afirmar que o que há de comum é a função da música nos respectivos rituais de cada comunidade. 
As romarias são peregrinações religiosas feitas pelos devotos em homenagem aos seus santos padroeiros. É possível deduzir que Daniel Pereira de Mattos, natural do Maranhão, região nordestina de forte influência das comunidades eclesiais de base da igreja Católica, trouxe consigo esta tradição cultural e a incorporou na ritualística desta missão. O CEOCPE possui alguns santos considerados como padroeiros da casa: Nossa Senhora da Conceição, Nossa Senhora da Glória, São Francisco das Chagas (São Francisco de Assis), São Sebastião e São José. Em homenagem a estes santos, são realizadas romarias ao longo do ano de acordo com a data festiva de cada um deles.

Cada romaria tem uma determinada quantidade de dias. Nesta época, diariamente, os fiéis realizam uma procissão até o templo e em seguida prestam um culto em homenagem aos santos. Os salmos cantados, dentro do compromisso das romarias, geralmente expressam no conteúdo das letras, súplicas e venerações aos padroeiros cultuados na Barquinha. No último dia de cada romaria (dia do santo homenageado), além do culto no templo, é realizado um festejo no terreiro (bailado). Nesta comunidade são realizadas as seguintes romarias (seguindo o calendário)

- 01 a 20 de janeiro - Romaria de São Sebastião.

- 01 a 19 de março - Romaria de São José.

- 01 a 31 de maio - Romaria de Nossa Senhora da Conceição.

- 01 a 15 de agosto - Romaria de Nossa Senhora da Glória.

- 01 de setembro a 4 de outubro - Romaria de São Francisco das Chagas.

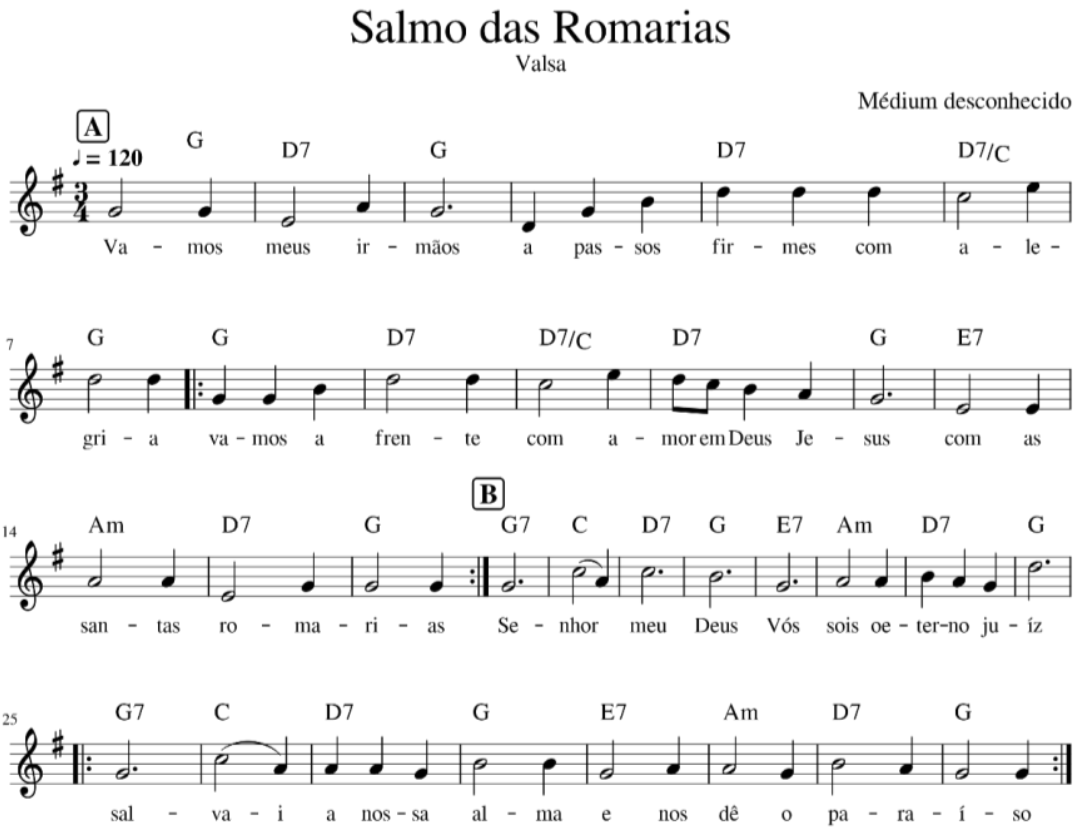

(Partitura 4) 
Vamos meus irmãos

A passos firmes com alegria

$\left.\begin{array}{c}\text { Vamos à frente com amor em Deus Jesus } \\ \text { Com as Santas Romarias }\end{array}\right\}$ Bis

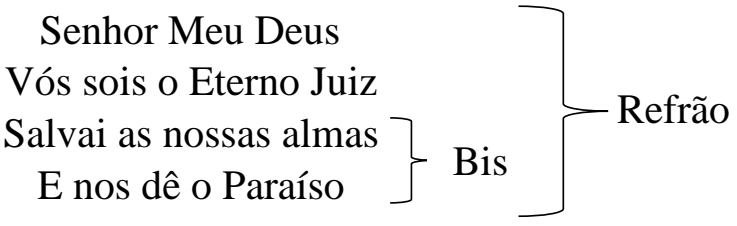

Sigo com os irmãos

Nestas lindas Romarias

$\left.\begin{array}{c}\text { Seguimos cantando louvores a Deus Jesus } \\ \text { E a Sempre Virgem Maria }\end{array}\right\}$ Bis

Este salmo é cantado durante a procissão que os romeiros fazem diariamente no período das romarias. No último dia do compromisso, a irmandade prepara o andor do santo homenageado e percorre uma distância maior pelas ruas circunvizinhas nos arredores da igreja.

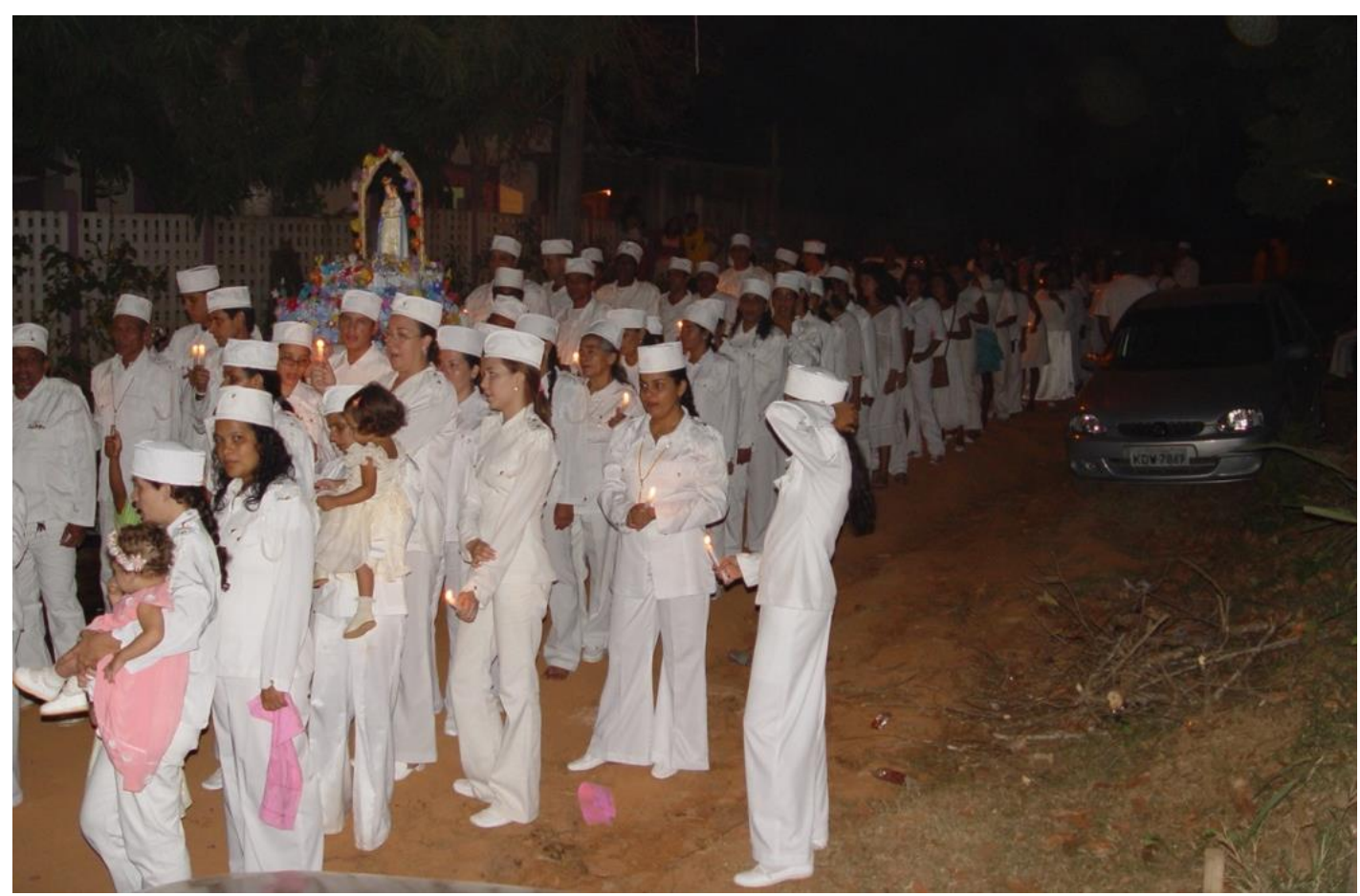

Foto 13 - Procissão da Romaria de Nossa Senhora da Glória no CEOCPE (15.08.2005). Fonte: Acervo CEOCPE

\section{- Obras de Caridade}

As "Obras de Caridade" é o trabalho de atendimento às pessoas que procuram o Centro em busca de um algum tipo de ajuda (problemas de saúde, problemas familiares, 
pessoais e etc.), sessão que ocorre aos sábados. Em suma, é realizado um culto no templo, enquanto no salão das obras (gongá), os médiuns recebem as entidades (as incorporam) que se apresentam para prestar a caridade aos clientes ${ }^{27}$, conforme o relato de Maria (nome fictício) membro do CEOCPE que entrevistamos em campo:

Muitos vêm atrás de um conselho amigo, uma orientação espiritual, uma palavra de fé e consolo, outros vêm em busca de cura. Com frequência recebemos pessoas "endemoniadas" que vem em busca de ajuda. Gente de muitos lugares aparecem por aqui, não somente de Rio Branco, mas de outros lugares do Brasil e, muitas vezes, pessoas estrangeiras que também vêm conhecer e buscar auxílio. Vem gente de tudo o que é tipo: pobre, rico, drogado, aleijado, gente humilde que muitas vezes não sabe nem ler e escrever, e também gente culta, enfim, todo tipo de gente.

Nos rituais das Obras de Caridade canta-se uma coroa de hinos de cura. Salmos que falam sobre fé, esperança, confiança no poder curador que emana de Deus, a exemplo do trecho do hino que coloco a seguir:

\section{Poder Curador}

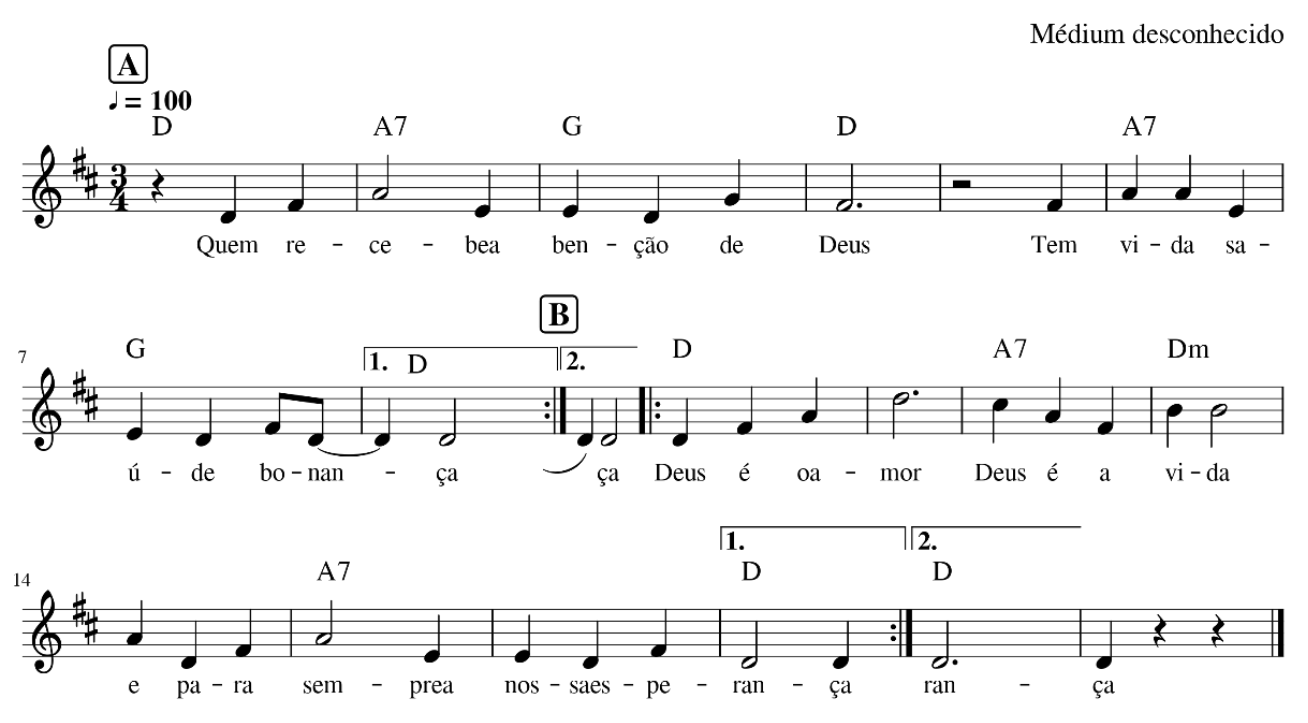

(Partitura 5)

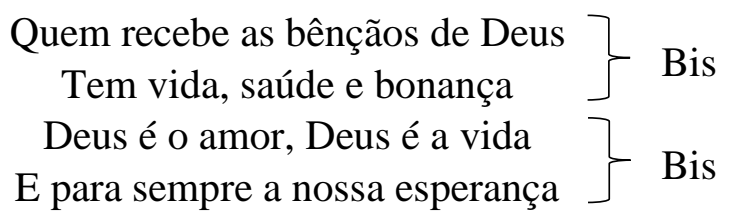

27 As Obras de Caridade são um serviço, ou benefício, gratuito que o Centro presta àqueles que o procuram. Não é realizada, portanto, qualquer cobrança financeira pela assistência prestada. Em algumas ocasiões, as entidades podem solicitar que o cliente providencie velas ou outros materiais para a realização de algum compromisso religioso relacionado ao seu tratamento. 
Baixou agora nesta mesa

O santo poder curador $\}$

Seis querubins, seis serafins

Primeiro Jesus Salvador

Enchemos o coração de fé E pedimos de Deus o amor

Ele é a verdade infinita

E em tudo é o poder curador $\}$ Bis

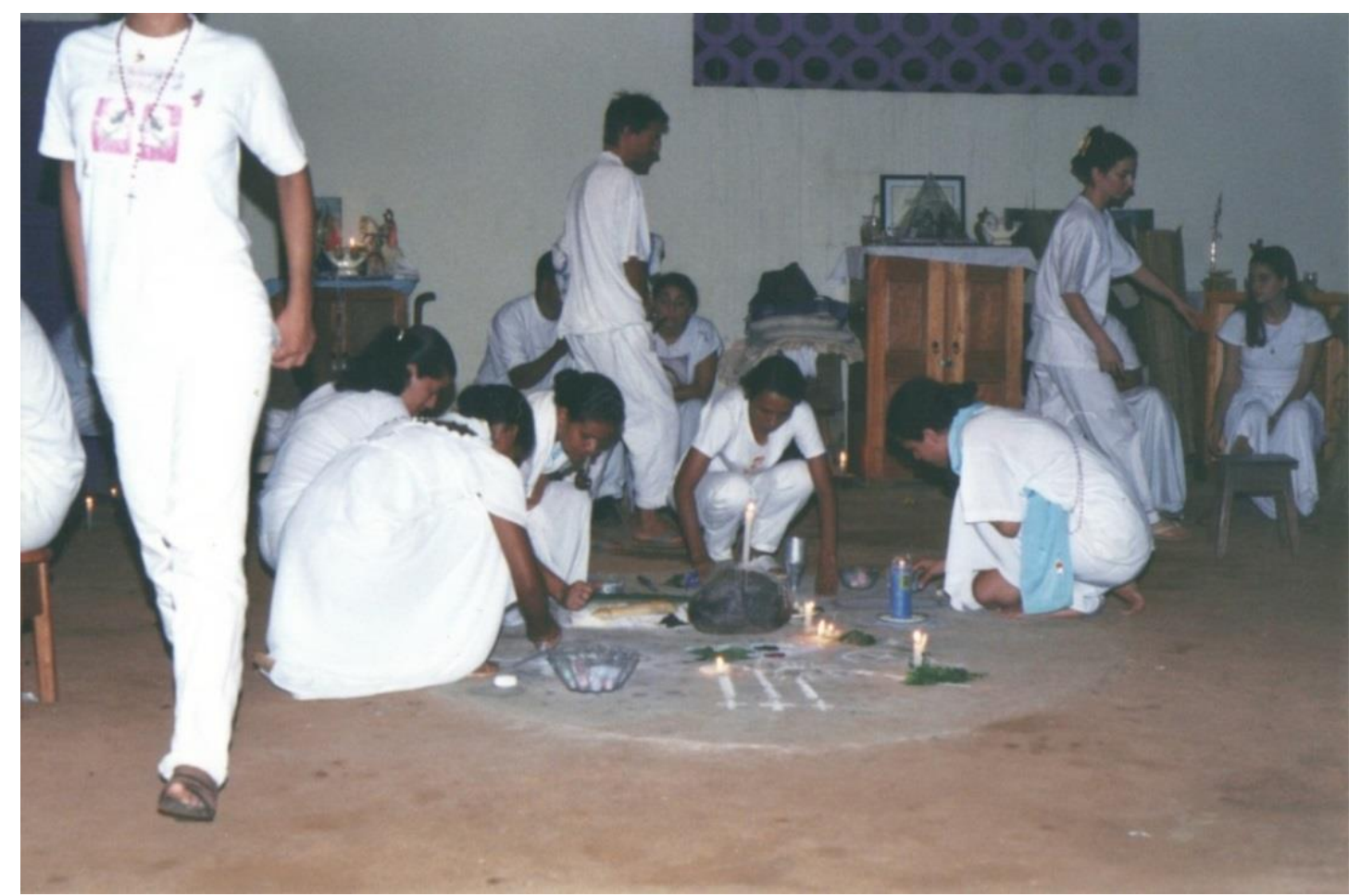

Foto 14 - Salão das Obras de Caridade ou Gongá, local onde os médiuns recebem as entidades para prestar atendimentos no CEOCPE. Fonte: Acervo CEOCPE

\section{* Trabalhos de Instrução}

São os cultos realizados todas as quartas-feiras, nos quais são cantados hinos contendo mensagens de instrução. Ao término da coroa de hinos, a Irmã de Caridade e, ou, uma entidade espiritual transmite uma palestra de instrução e orientação. O objetivo maior dos trabalhos de instruções é preparar a irmandade para realizar as Obras de Caridade no sábado vindouro, além de servir de preparo para todos os trabalhos prestados na missão. 


\section{São Francisco de Assis}
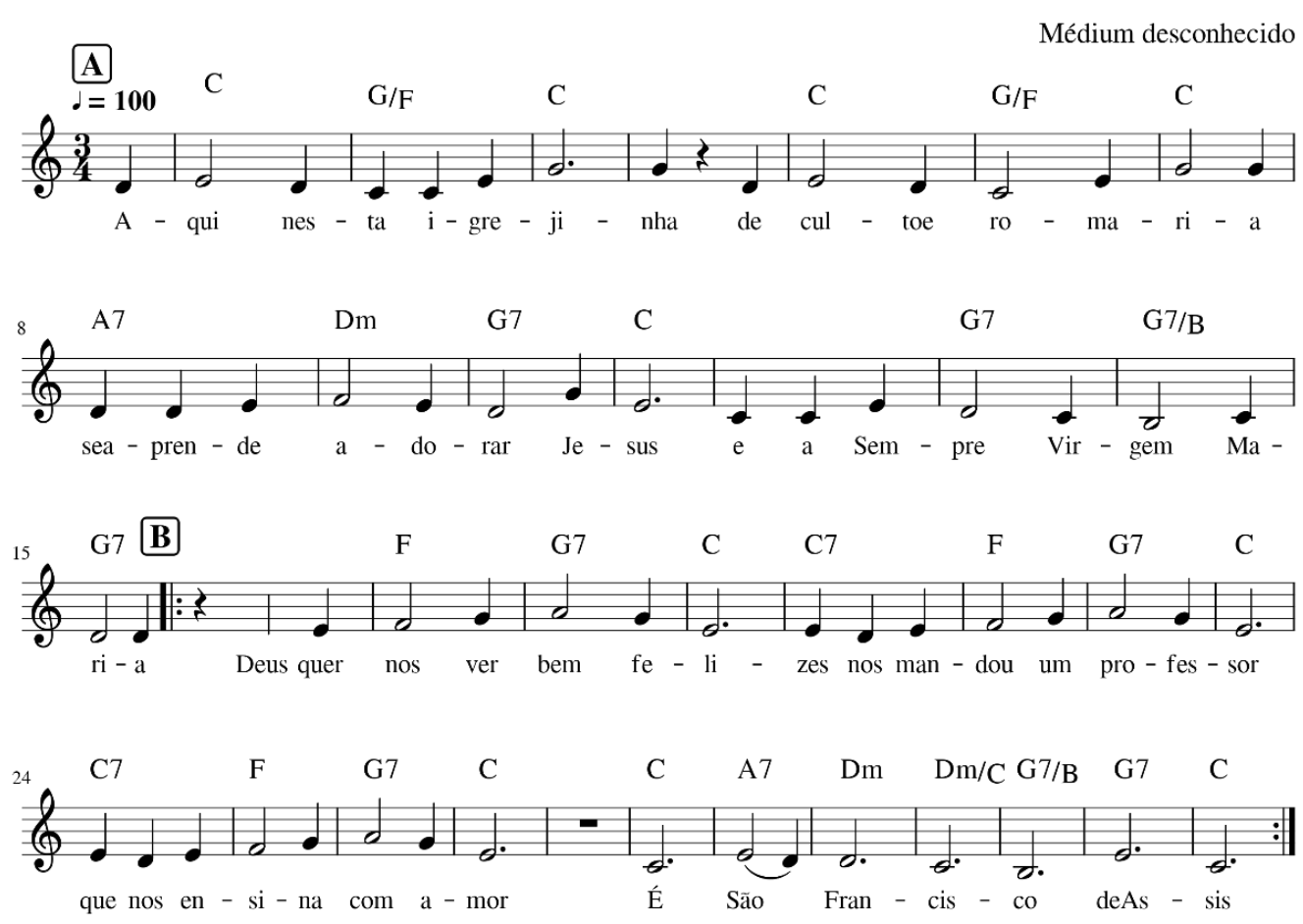

(Partitura 6)

Aqui nesta Igrejinha de culto e romaria

Se aprende a adorar Jesus e a sempre Virgem Maria

Deus quer nos ver bem felizes nos mandou um professor

Que nos ensina com amor, é São Francisco de Assis

São Francisco está na mesa com o livro santo nas mãos

E nos ensina com firmeza fazer nossas devoções

$\left.\begin{array}{l}\text { Irmãos, estamos felizes temos um santo professor } \\ \text { Que nos ensina com amor, é São Francisco de Assis }\end{array}\right\}$ Bis

Precisamos aprender a santíssima cortesia

De falar com Deus Jesus e a sempre Virgem Maria

Deus é quem nos faz felizes por isso ele nos mandou

Um santíssimo instrutor, é São Francisco de Assis

\section{- Prestamento ${ }^{28}$ de Contas}

No dia 27 de cada mês do ano é realizado um culto específico, com o objetivo de se "prestar contas" a Deus das obras espirituais e materiais, realizadas no período de um mês. Conforme os relatos obtidos, neste dia cada membro deve fazer um exame de consciência e avaliar o seu desempenho dentro do seguimento religioso. Além disso, é

${ }^{28}$ Esta é a forma como os membros chamam este rito, apesar de que, de acordo com a norma culta da escrita, o correto seria "prestação" de contas. 
também o momento de se prestar contas materialmente, ou seja, dia de pagamento do dízimo.

\section{Castelo Azulado}

Bolero

Recebido por Daniel Pereira de Mattos
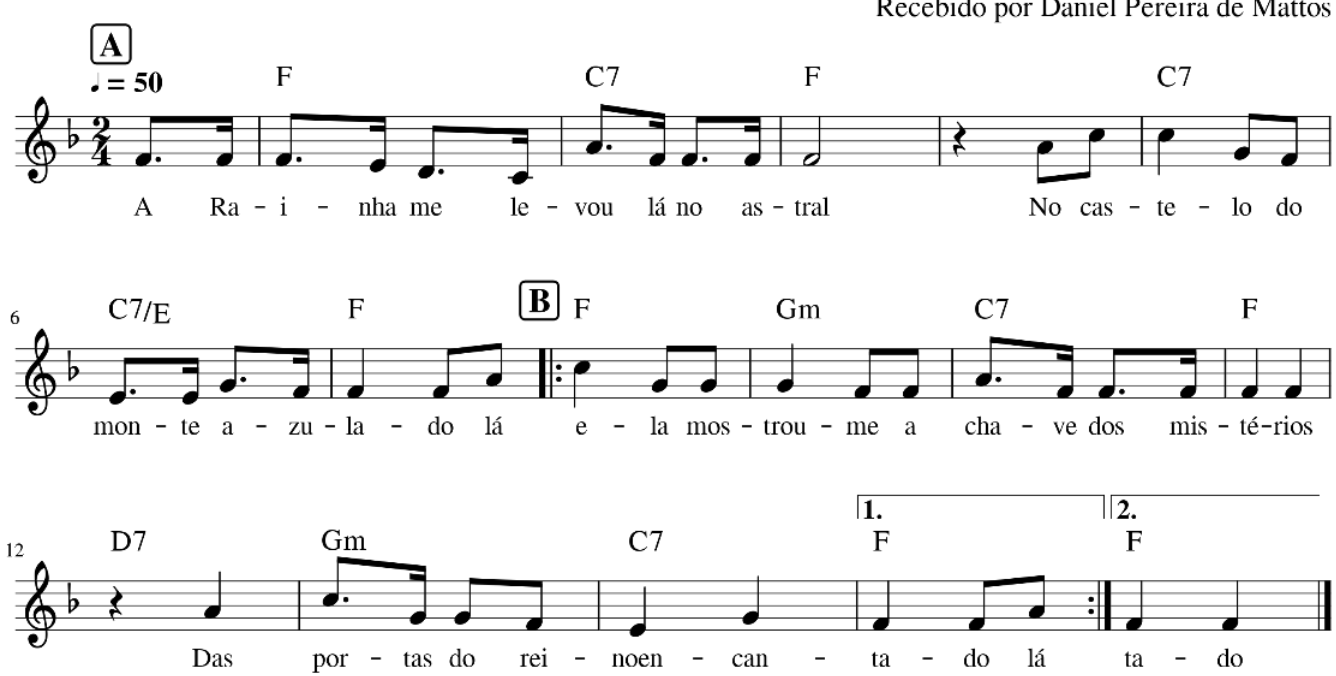

(Partitura 7)

A Rainha me levou lá no astral

No castelo do monte azulado

Lá ela mostrou-me a chave dos mistérios

Das portas do reino encantado

Bis

Meus irmãos façam o sinal da Santa Cruz

E se afirmem na concentração

Que eu estou no Astral no Castelo Azulado

Prestando contas desta Sessão

Bis

Os Hinos que eu canto aqui nesta Sessão

Em todos tem o Nome de Deus

E tudo que eu afirmo com o seu Sagrado Nome

Quem tem que prestar contas sou eu

Bis

A conta que estou a prestar lá no Astral

É para Deus e a Virgem da conceição

E também estou recebendo o Livro da ciência

Dos Mistérios aqui desta Sessão

Bis

\section{* Doutrina de almas}

Segundo os relatos colhidos, a doutrina de almas é uma seção realizada em benefício das almas desencarnadas (falecidas), que se encontram numa situação difícil no plano espiritual. Este trabalho se dá da seguinte maneira: no plano espiritual os 
"pastores de almas", que são seres espirituais obreiro da missão (considerados como missionários, sacerdotes e etc.), estariam "resgatando" almas que estão perdidas, longe da presença de Deus, colocando-as em um local de preparo, onde elas estariam aguardando o dia em que serão doutrinadas (uma espécie de benefício para essas almas).

Estes rituais ocorrem, geralmente, em épocas de Romarias, pois é nesse período que a irmandade está em penitência, oferecendo orações à bem destas almas necessitadas. No dia da doutrina é realizado um culto no templo, com exceção do dia de finados, quando a seção é feita no local onde fica o cruzeiro. Durante o ritual, canta-se uma coroa de hinos específica, que fala sobre as almas que desencarnam.

\section{Almas na Escuridão}

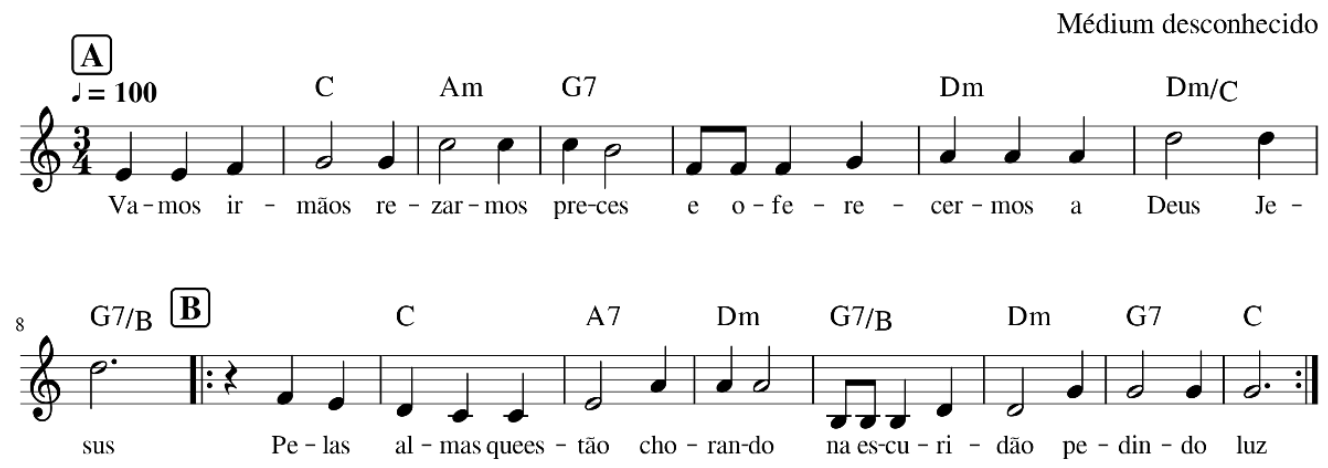

(Partitura 8)

Vamos irmãos rezarmos preces

E oferecermos a Deus Jesus

Pelas almas que estão chorando

Na escuridão pedindo luz Bis

Lá não se compra e não se vende

O conforto é a santa luz

Quem segue a Deus para sempre tem

O pão da vida o Senhor Jesus

$\mathrm{O}$ que eu recito neste hino

É preciso haver compreensão

São daqueles que nesta vida

Encheram a alma só de ilusão Bis

Neste mundo fui muito rico

Muito rico, mas de ilusão

Hoje estou fora da matéria

Sofrendo na escuridão Bis 
Perdi toda felicidade

Pelas riquezas da ilusão

Hoje estou fora da matéria

Sem esperança de salvação $\}$ Bis

Este hino é uma embaixada

Que me veio da eternidade

$\left.\begin{array}{c}\text { Para rezarmos e rogarmos a Deus } \\ \text { Pelas almas necessitadas }\end{array}\right\}$ Bis

\section{* Batismo de pagãos}

No contexto da Barquinha, o termo pagão é uma referência às entidades espirituais que ainda não teriam recebido o "batismo" dentro da Casa. Segundo os relatos, são "Exus", "pombas-gira”, "erês”, "preto-velhos", “caboclos”, enfim, espíritos que precisariam ser batizados e doutrinados para se prepararem para cumprir a missão cristã na Barquinha.

\section{Batismo}
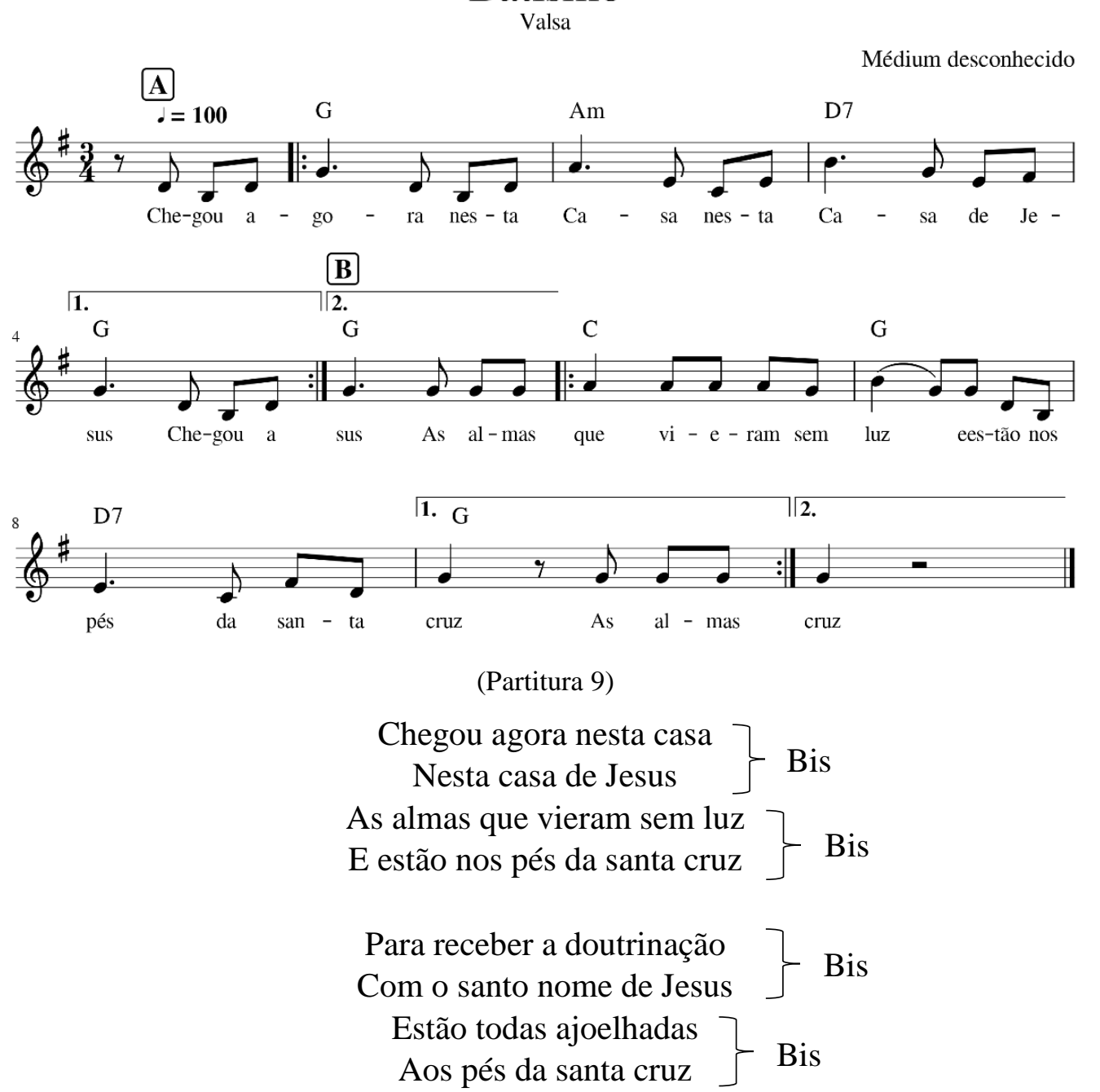


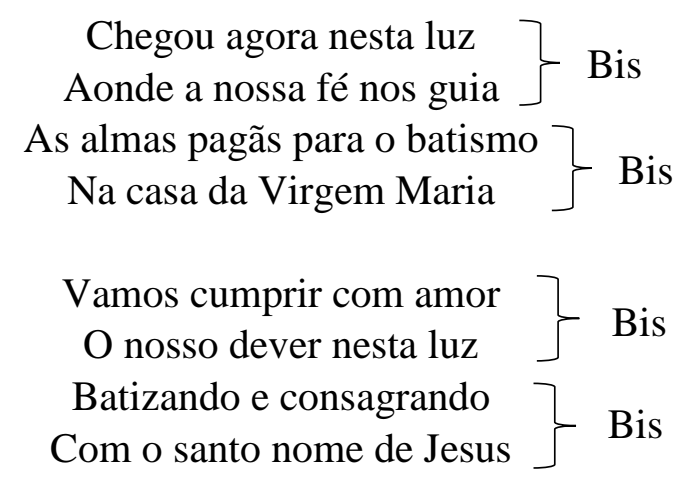

\section{* Feitio}

Trata-se de do ritual de preparação da bebida enteógena, denominada Santo Daime. Basicamente, o Daime pode ser entendido como um chá feito de um cipó (Banisteriopsis caapi), uma folha (Psychotria viridis) e água que juntos são levados ao fogo em grandes panelas. Primeiramente, colhe-se o cipó Mariri, ou Jagube, depois as folhas Rainha, também conhecidas como Chacrona. Daí em diante é preciso executar todos os preparativos para dar início aos trabalhos de feitura do Daime. Providencia-se a lenha, água potável, além da lavagem e raspagem do cipó, e lavagem das folhas. É importante ressaltar que todos os procedimentos relativos à confecção da Santa Luz são envoltos de um clima de sacralidade entre todos os envolvidos.

Segundo os relatos colhidos, no CEOCPE, o ritual do feitio passou por algumas etapas de desenvolvimento até chegar na forma atual. Conta-se, por exemplo, que conhecimentos foram sendo agregados às técnicas de "batição" do cipó, ao tipo de fornalha utilizada, e outros utensílios e ferramentas.

\section{Do Santo Amor Apareceu}

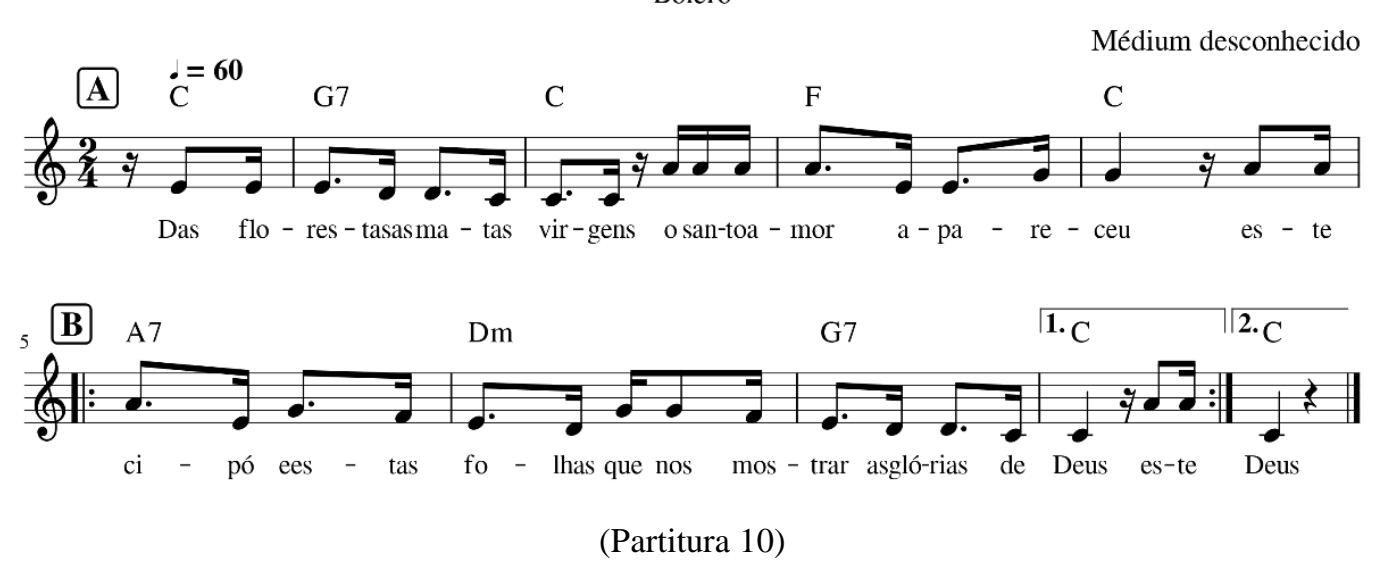


Das florestas as matas virgens

Do santo amor apareceu

Este cipó e estas folhas Que nos mostra as glórias de Deus $\}$ Bis

Com o cipó, fogo, água e folha

São essas as combinações

Que se prepara esta bebida

Que nos dá santa miração $\}$ Bis

Esta bebida em verdade

É de um respeito exemplar

Nos dá luz e nos ensina

A Deus do céu adorar

\section{Bis}

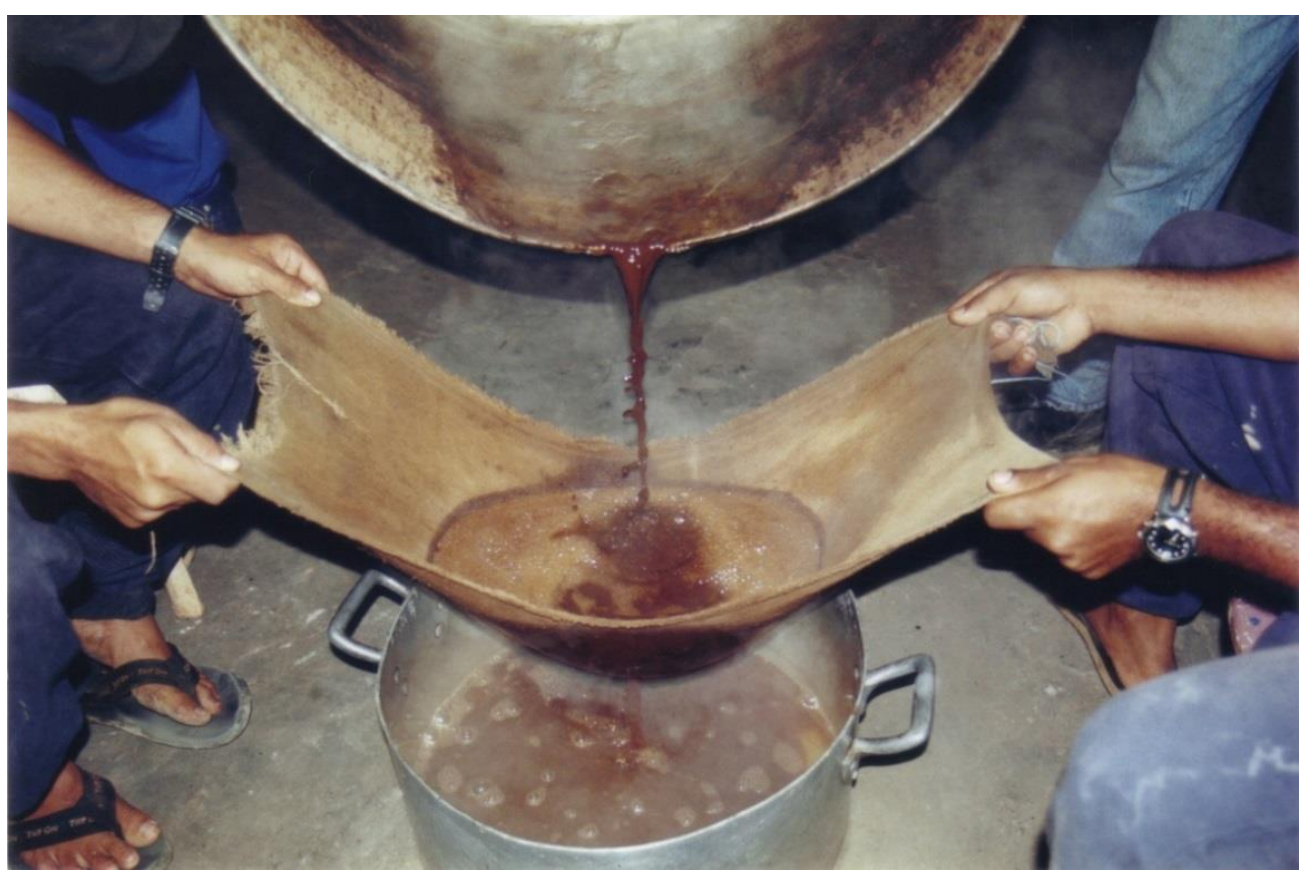

Foto 15 - Processo de confecção do daime no CEOCPE. Fonte: Acervo CEOCPE

\section{* Rosário de Nossa Senhora}

Semanalmente, todo domingo às 16 horas é realizado o compromisso da oração e recitação do Rosário de Nossa Senhora. Durante o rosário, são cantados hinos entre os interstícios de cada terço, de acordo com os mistérios do Rosário. Por exemplo, nos mistérios gozosos, pode ser cantado um hino de Natal (o nascimento de Jesus). Já nos mistérios dolorosos, pode ser cantado um hino relativo à paixão de Cristo, e assim por diante. 


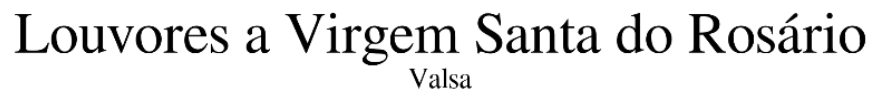
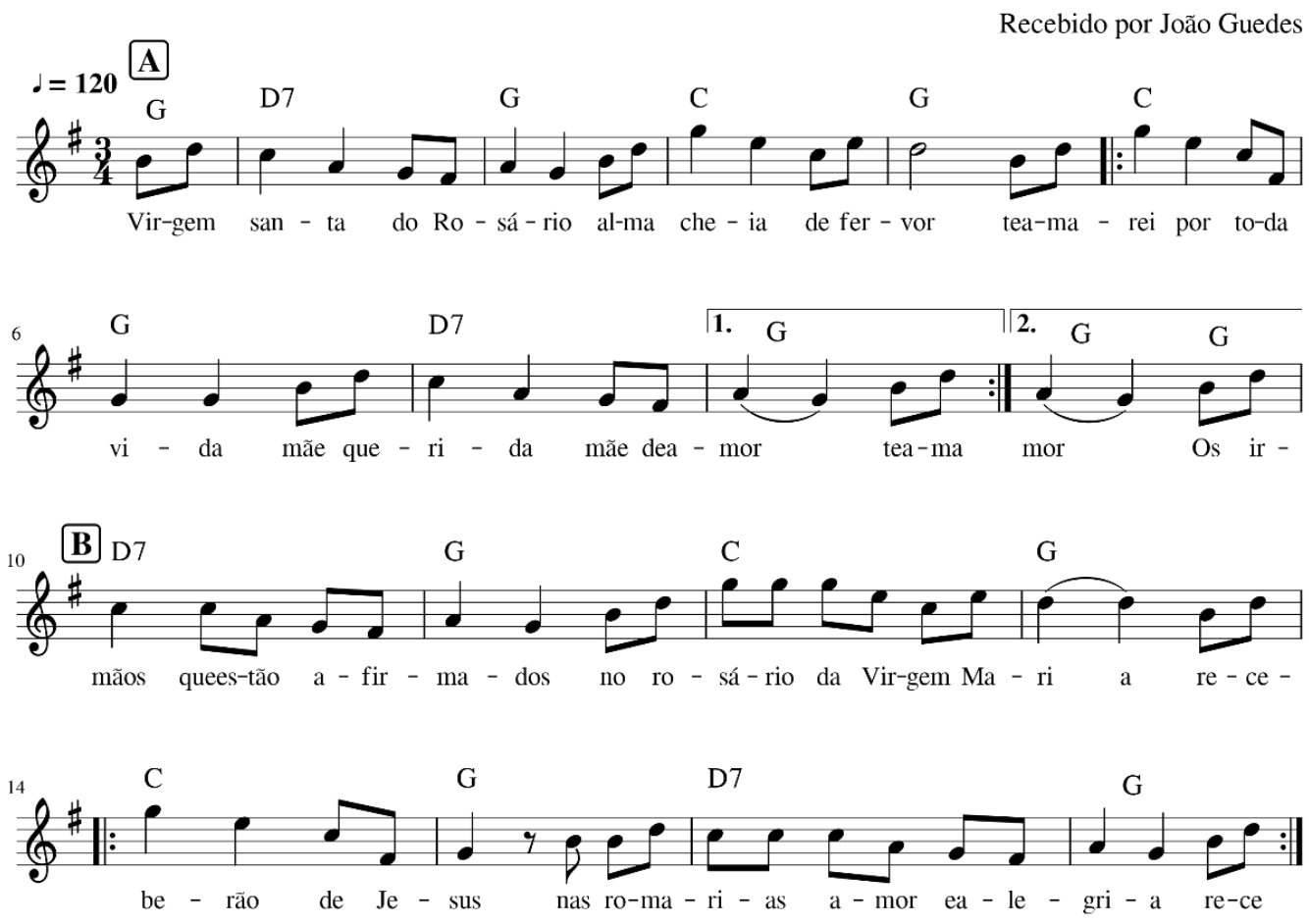

(Partitura 11)

Virgem santa do Rosário

Alma Cheia de fervor

Te amarei por toda a vida

Mãe querida, mãe de amor

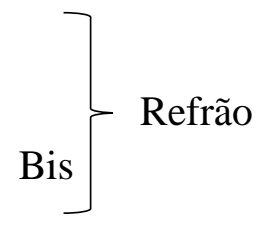

Os irmãos que estão afirmados

No rosário da Virgem Maria

$\left.\begin{array}{c}\text { Receberão de Jesus } \\ \text { Nas romarias amor e alegria }\end{array}\right\}$ Bis

Os mistérios que recebemos

Do rosário da Virgem Maria

Servirão de luz e fortaleza

De paz e firmeza nas romarias Bis

Meus irmãos seguimos firmes

Nesta Casinha com alegria

$\left.\begin{array}{c}\text { Com a Irmã de Caridade } \\ \text { Rezando o rosário da Virgem Maria }\end{array}\right\}$ Bis

\section{* Quaresma e Semana Santa}

A Quaresma é um compromisso de tradição católica, realizado em referência aos 40 dias que Jesus passou no deserto preparando-se para a missão que tinha pela frente. 
A irmandade passa então 40 dias cumprindo um compromisso em preparação para a Semana Santa, no qual se reúne diariamente para fazer orações e cantar salmos relativos à Paixão de Cristo. Na Semana Santa existe uma coroa de hinos específica para o evento em questão.

\section{Meu Bom Jesus \\ Valsa}
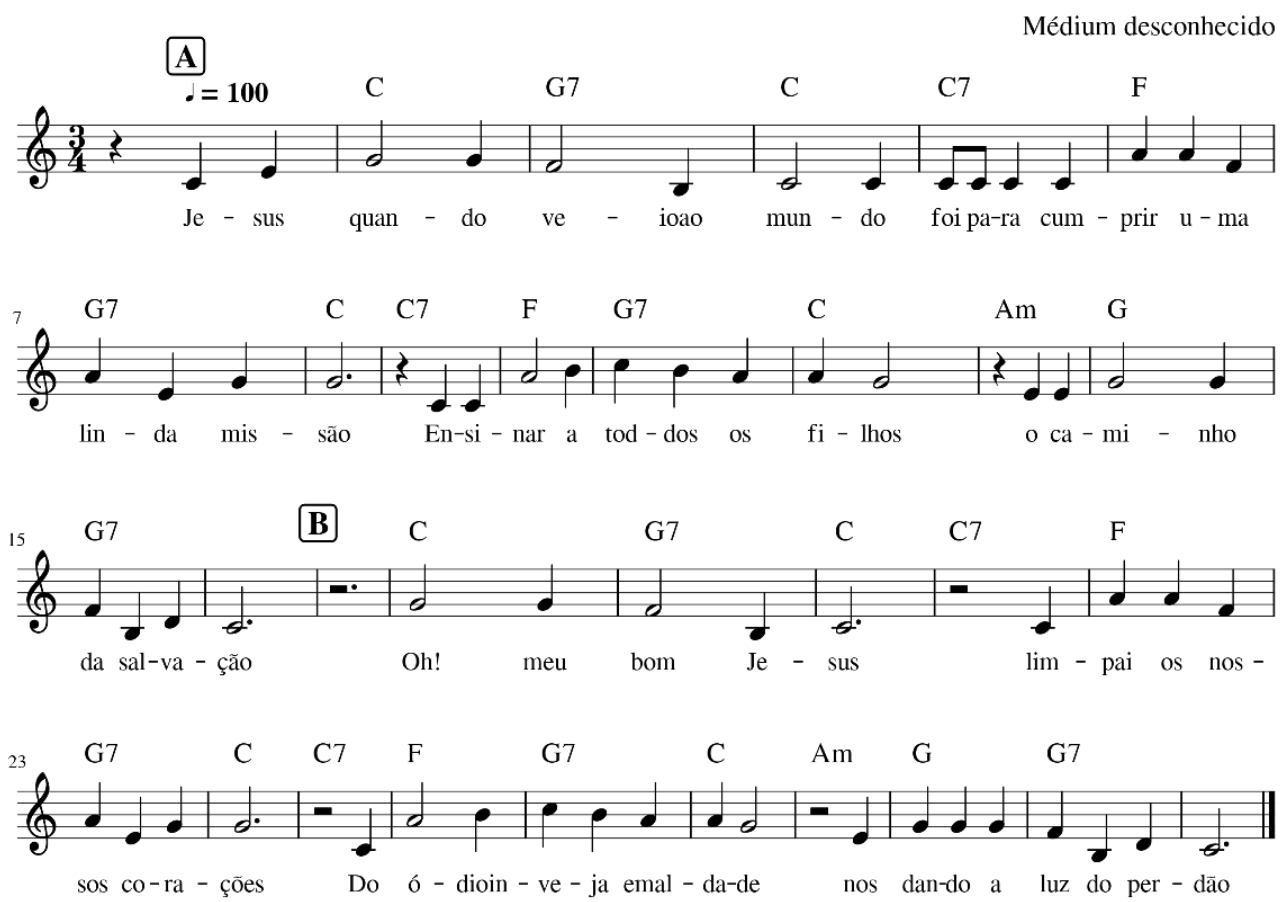

(Partitura 12)

Jesus quando veio ao mundo

Foi para cumprir uma linda missão

Ensinar a todos os filhos

O caminho da salvação

Oh! meu bom Jesus

Limpai os nossos corações

Do ódio, inveja e maldade.

Refrão

Limpando os nossos corações

Ele foi preso e amarrado

E o madeiro carregou

E cumprindo sua missão

Os seus filhos ele perdoou

Irmãos vamos fazer penitências

Com fé, amor e lealdade

Que nós teremos as santas bênçãos

Do nosso pai de bondade 
Assim meus irmãos amigos

Vamos cumprir nossa linda missão

Deixando o ódio, inveja e maldade

E rogando o nosso perdão

\section{* Festas, bailados e comemoraçães}

As festas são comemorações realizadas no salão das festas, também conhecido como "terreiro" no CEOCPE. Os dias de festas geralmente são as datas dos santos mais cultuados na missão. São Francisco das Chagas, São José, São Sebastião, Santo Antônio, São João Batista, São Pedro, Santa Ana, São Jorge, Santa Bárbara, entre outros. Outras datas são: 08 de setembro - dia da passagem do Fundador para o mundo espiritual (Falecimento); 23 de novembro - data da fundação do Centro em que é feita uma homenagem ao Príncipe Espadarte do Mar (Dom Simeão); Natal; Ano Novo; Celebrações matrimoniais; aniversários de membros da missão entre outras datas.

\section{Começamos a brincar \\ Marcha}

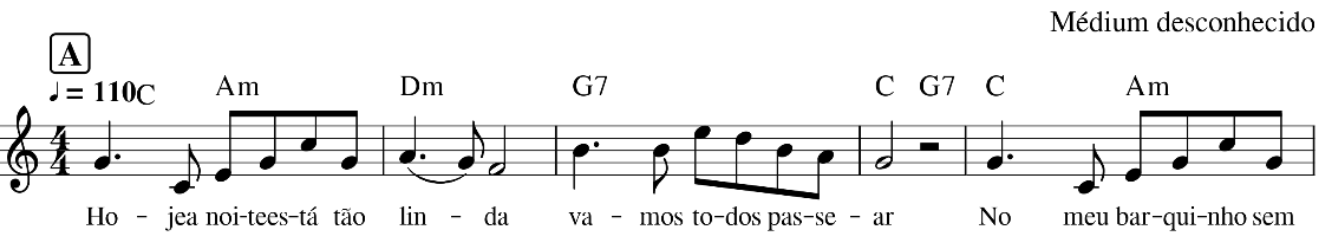

B

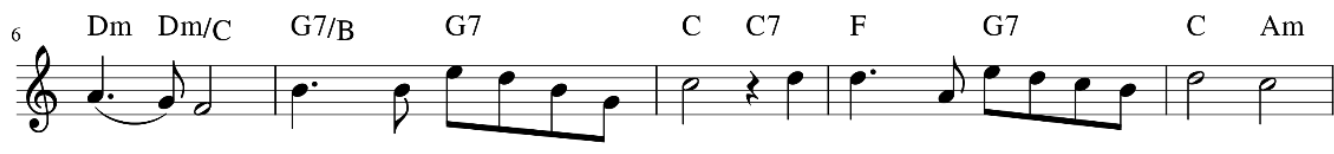

ve - las so - bre as á-guas do mar Se - gui - mos to-dos no bar - qui - nho

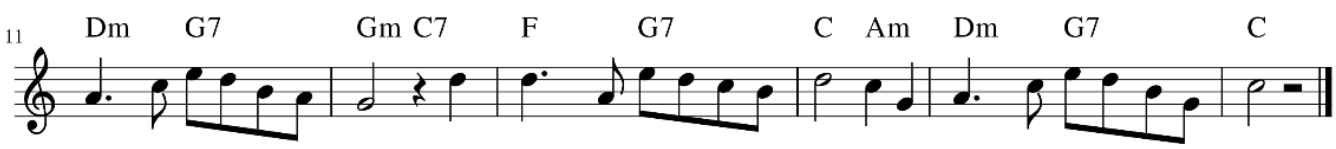

so - bre as á-guasdo mar Lou - van - doaSăo Jo-ão Ba - tis - ta ea Săo Jo-sédoA-rri-ba - mar

(Partitura 13)

Hoje a noite está tão linda

Vamos todos passear

No meu Barquinho sem velas

Sobre as águas do mar

Seguimos todos no Barquinho

Sobre as águas do mar

Louvando a São Batista

Refrão

E a São José do Arribamar 
Eles vêm com alegria

Para nos apreciar

Com eles vêm todos os encantos

Para hoje aqui brincar

Hoje aqui nesta casinha

Todo mundo vai brincar

Com os lindos encantos

Do céu, da terra e do mar.

No salão é realizado um bailado em forma de gira, aonde se invocam a presença das entidades que "irradiam" os médiuns da casa, que bailam ao som dos pontos entoados ao ritmo dos atabaques e de instrumentos harmônicos.

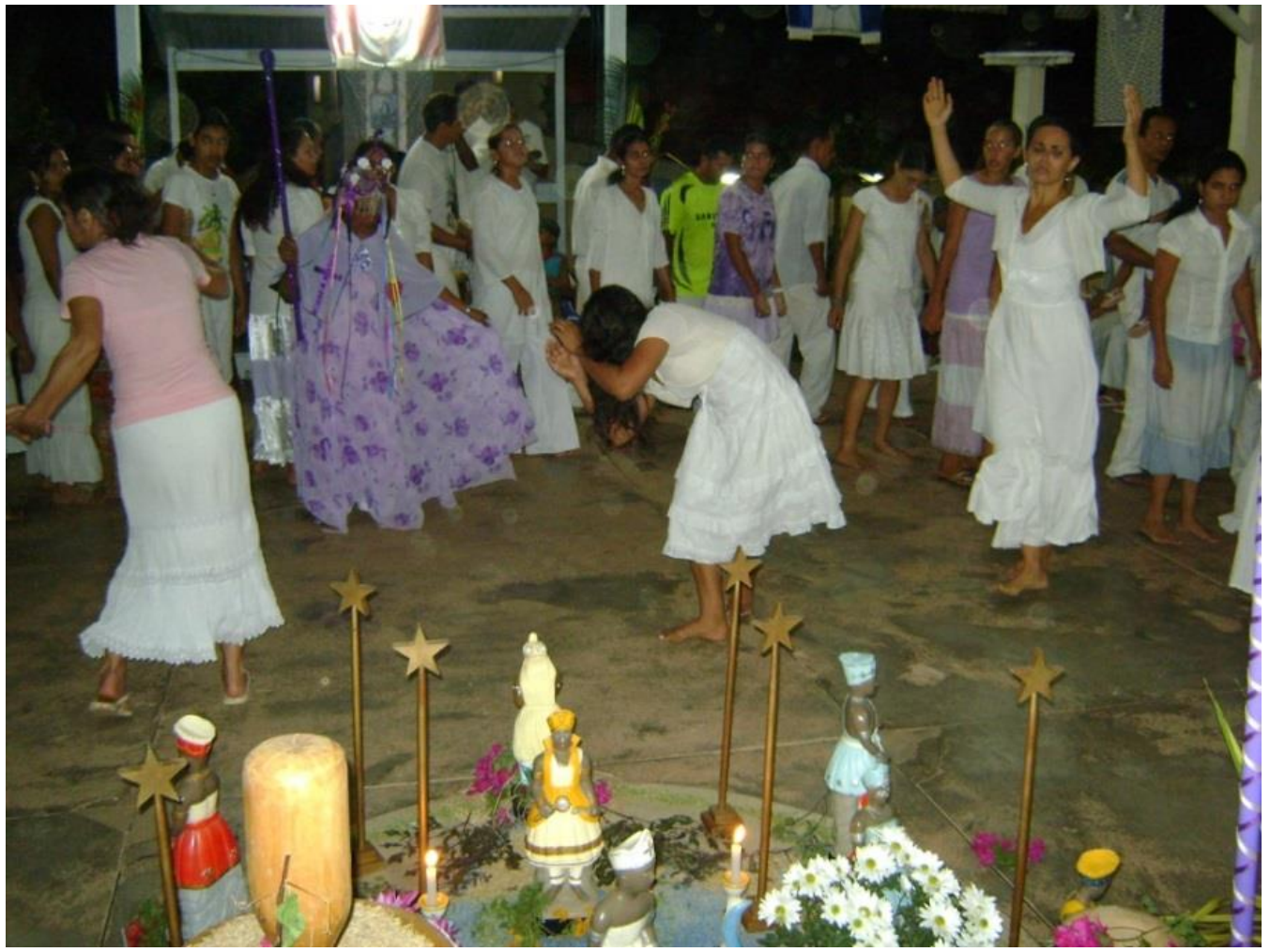

Foto 16 - Um dia de festa no CEOCPE. Fonte: Acervo CEOCPE

\section{* Batismo de crianças}

O batismo de crianças, e também de jovens e adultos ainda não batizados e que decidem por recebê-lo, é outra atividade realizada no Centro. Durante o ritual de batismo é cantada uma coroa de hinos específica para a ocasião. Os fiéis relatam que o batismo é feito por um missionário do plano astral. A Irmã de Caridade recebe (incorpora) a entidade que realiza o batismo com características similares a um batizado 
na igreja católica. Os nomes das pessoas batizadas e seus respectivos pais e padrinhos são anotados em um caderno para fins de arquivamento.

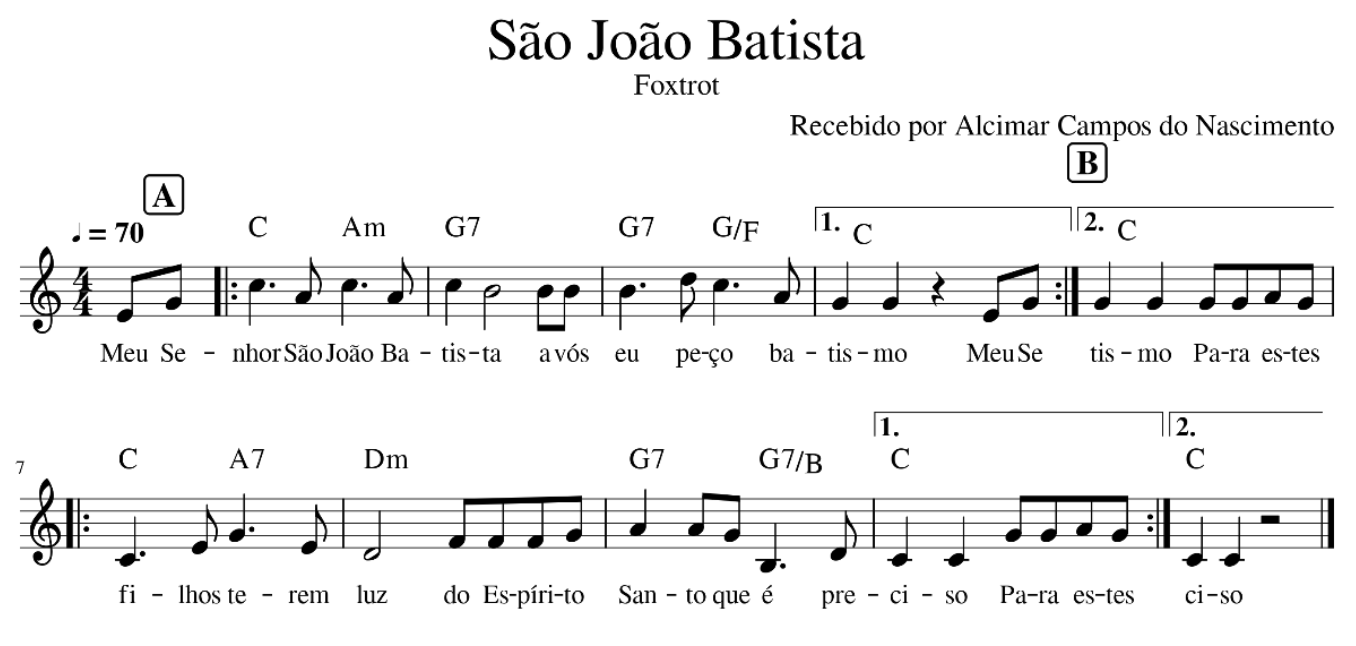

(Partitura 14)

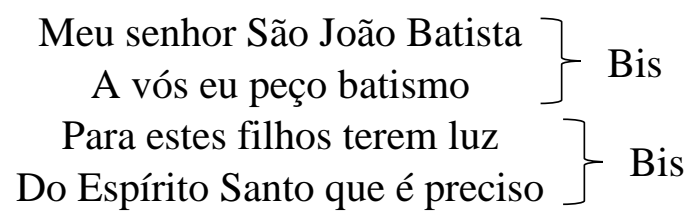

$\left.\begin{array}{l}\text { Vós batizou o senhor Jesus } \\ \text { Do mesmo recebeu batismo }\end{array}\right\}$ Bis

$\left.\begin{array}{l}\text { O Espírito Santo os consagrou } \\ \text { Eternos cristos no paraíso }\end{array}\right\}$ Bis

$\left.\begin{array}{l}\text { Com o sal do mar sagrado } \\ \text { Com a água do rio Jordão }\end{array}\right\}$ Bis

$\left.\begin{array}{c}\text { Com a cinza do fogo sagrado } \\ \text { Eles são filhos de São João }\end{array}\right\}$ Bis

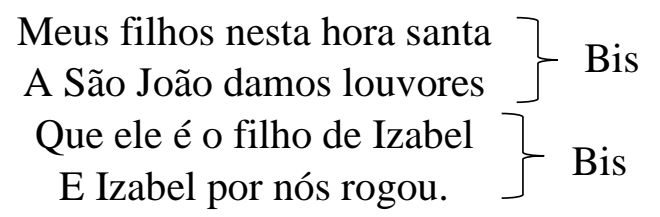

Além destas atividades descritas acima, outros compromissos são realizados no CEOCPE, tais como o compromisso das Mil Ave Marias (três vezes ao ano), o Cerco de Jericó (O Grande Rosário, realizado uma vez ao ano), e festas de aniversários, celebrações matrimoniais entre outros eventos. É importante relembrar que cada Centro desenvolve a sua própria rotina de atividades. 
A Barquinha é um segmento religioso que mantem uma tradição extremamente musical, praticamente todos os seus rituais são permeados pela música local. Nestas comunidades, a cultura e os costumes locais são de tradição oral, transmitidas de geração a geração ao longo do tempo. A ritualística que compõe os cultos de orações, as obras de caridades, as romarias, as devoções religiosas, o bailado (festejos), o feitio do daime, busca de cipó e folhas e todas as demais atividades desta missão religiosa são de tradição oral, estando em pleno processo de modelação desde a fundação desta doutrina religiosa até os dias atuais.

\subsection{Organicidade da cosmologia da Barquinha}

A missão de Mestre Daniel tem demonstrado uma notável capacidade de se modelar ao longo do tempo e do espaço. Afirmamos isso ao observar a dinamicidade referente ao desenvolvimento da ritualística de cada Centro. Sena Araújo (1999), ao fazer uma laboriosa etnografia no CECOCJFL, produziu importantes dados sobre o contexto histórico da formação da Barquinha, além de elencar elementos que nos ajudam a entender as características inerentes aos rituais desta tradição.

Das práticas religiosas que compõe a Barquinha, podemos dizer que esta tem características do xamanismo indígena, da umbanda, do círculo exotérico da comunhão do pensamento e do catolicismo popular. A Barquinha está sempre em construção, porque seus marinheiros dão continuidade ao trabalho iniciado por Daniel nessa doutrina eclética, na qual elementos de práticas religiosas são incorporados ou retirados de acordo com ordens provenientes do invisível. (1999, p.74)

Em campo, os relatos obtidos apontam que a rotina de trabalhos do CEOCPE se estruturou gradativamente num processo orgânico. Dona Chica Gabriel, no papel de líder da comunidade, administra este desenvolvimento de acordo com a experiência que adquiriu ao longo de todos esses anos de dedicação à missão, e também conforme as necessidades que vão se apresentando durante a empreitada. Obviamente, vários outros fatores interferem também no processo de formação desta cosmologia. Por exemplo, o compromisso da oração dominical do Rosário de Nossa Senhora só foi implementado no calendário ritualístico do CEOCPE por volta do ano 2000. Segundo as informações colhidas, a Irmã de caridade resolveu incluir esta atividade na rotina de trabalhos do Centro como forma de "reforçar" a guarnição espiritual da casa, fortalecer a irmandade de um modo geral, num momento em que ela viu a necessidade disto. 
Com a música local não é diferente. Observa-se uma grande capacidade de modelação da mesma. São novas obras musicais que chegam (hinos, salmos e pontos), novos músicos que vêm trazendo uma bagagem de conhecimentos, somando esforços, ideias, experiências, renovando e diversificando à prática de conjunto, acrescentando novos instrumentos, novos timbres, novas ideias de harmonização das melodias, novas performances musicais, novos arranjos. Assim como também, novos equipamentos, novas ferramentas de sonorização de ambiente, tudo isto propicia e movimenta este vivo processo de modelação da prática musical local.

\subsection{Desafios da análise musical da música da Barquinha}

A análise musical, geralmente, é tida como o campo das ciências musicais que estuda a música em si mesma, desvinculadas de fatores externos. Com base no Grove's Dictionary, além de outras fontes bibliográficas ${ }^{29}$, Antenor Ferreira Correa (2006) nos apresenta uma definição sucinta sobre isto:

Análise é entendida como o processo de decomposição em partes dos elementos que integram um todo. Esse fracionamento tem como objetivo permitir o estudo detido em separado desses elementos constituintes, possibilitando entender quais são, como se articulam e como foram conectados de modo a gerar o todo de que fazem parte. Justifica-se esse procedimento por admitir-se que a explicação do detalhe sobre o conjunto conduz a um melhor entendimento global. (p.33)

A música considerada em si mesma refere-se à análise dos elementos que integram sua estrutura, como motivos, frases, períodos, seções, escalas, tonalidade, modulações, regiões, aspectos melódicos, harmônicos, polifônicos, texturais, rítmicos, entre uma série de outros componentes que poderiam também ser mencionados. (p.48-49)

Entretanto, Correa (2006) expõe a seguinte reflexão: existe a música em si mesma? (p.49) A análise é uma atividade estritamente intelectual. Ora, qualquer consideração acerca de uma dada obra musical é realizada por intermédio de um agente externo: o analista, ou seja, um ser humano que possui sua própria personalidade, opiniões, visão de mundo e etc..

Esta exigência aumenta o problema da restrição do processo analítico à música nela mesma, já que a música age no intelecto do ser humano que a recebe. (...) Assim, valeria a questão: a música em si é aquela ouvida por um sujeito ou trata-se daquela fabricada pelo compositor e impressa no papel? (...) Essa situação aponta para o paradoxo da

${ }^{29}$ Harvard Dictionary, The New Oxford Companion to Music, Science de La Musique, Dictionnaire de la Musique, Dizionario Enciclopedico Uneversale Della Musica e Dei Musicisti, para citar alguns exemplos. 
análise musical: pretender analisar racional e objetivamente um fenômeno emocional e subjetivo. (p.49)

A música como uma manifestação artística de um dado grupo social é um produto da cultura local. É o resultado da mistura de diversos fatos históricos e das relações sociais estabelecidas no seio da comunidade ao longo do tempo. Para o autor, estas considerações, somadas ainda ao fato de que uma análise realizada é carregada da pessoalidade de quem a realiza, revelam a fragilidade da tentativa de se desvincular a análise musical dos fatores externos intrínsecos ao contexto estudado.

Começo esta seção deixando claro que o meu objetivo aqui é tentar trazer para o leitor um panorama do universo musical da Barquinha. Descrevo o que foi coletado em campo, por meio de uma etnografia da música da Barquinha, realizada de acordo com os princípios teóricos propostos por Anthony Seeger (2004). Lograrei êxito nesta exposição, se por um acaso o leitor tiver a oportunidade de conhecer, por meio deste trabalho, um pouco da realidade abordada aqui. Talvez, isto seja muita presunção da minha parte, principalmente pelo fato de que as pesquisas etnográficas representam não mais do que o ponto de vista de quem se propõe a observar uma dada cultura, e não a realidade propriamente dita, tal como foi salientado por Acácio Tadeu de C. Piedade (2008):

(...) uma descrição de uma performance musical, mesmo rica e detalhada, constitui apenas uma perspectiva possível, já que quem a produz é um sujeito que, sendo limitado por sua natureza, somente pode produzir a sua própria visão do objeto, decorrente de seu recorte teórico. (p.234)

Nenhuma pessoa ou disciplina possui o monopólio das questões que podemos fazer sobre música. Se nossas respostas diferem é porque as perspectivas dos eventos são diferentes. (...) Se trabalharmos juntos, poderemos (...) compreender o fenômeno que por nós mesmos só podemos perceber parcialmente. (Seeger, 2004, p.256)

Diante disto, devo reformular a tempo o que foi dito: lograrei êxito nesta exposição se por um acaso conseguir transmitir com clareza para o leitor aquilo que selecionei e interpretei, referente ao que vi, ouvi e pesquisei durante esta investigação. Por fim, pretendo com isso contribuir para a construção dos saberes relacionados ao objeto de estudo deste trabalho.

\subsection{Análise musical}

O conjunto dos cânticos da tradição religiosa fundada por Mestre Daniel é composto por um aglomerado de hinos, salmos, benditos e pontos de diversos 
compositores ligados a esta missão cristã. Coloco aqui a palavra "compositores" em itálico, porque como vimos no capítulo anterior, na tradição da Barquinha corresponde a um tema um tanto delicado.

Para entendermos o que é o repertório da Barquinha, devemos levar em consideração o fato de que cada comunidade desenvolveu (e continua desenvolvendo) o seu próprio conjunto de cânticos, formado, de um modo geral, pelo o que pode ser chamado de "hinos antigos" (recebidos por Mestre Daniel, entre outros membros da comunidade primogênita) e os outros cânticos que foram sendo canalizados pelos médiuns de cada Centro, após a segregação do primeiro grupo. Por exemplo, o repertório do CEOCPE é formado pelas mensagens que os próprios integrantes da Casa receberam desde sua fundação no ano de 1991, somadas aos cânticos recebidos na comunidade original até a saída de Dona Chica Gabriel no início da década de 90. Da mesma forma, podemos entender o repertório do CEDPM como a soma dos hinos que foram recebidos pelos membros do Centro, desde sua fundação no ano de 1979, mais os hinos recebidos na primeira comunidade até o desligamento do Mestre Antônio Geraldo. Portanto, o que é comum ao repertório dos três Centros citados aqui são os cânticos que foram recebidos no primeiro grupo, desde sua fundação em 1945, até a saída de Mestre Antônio Geraldo. ${ }^{30}$

Antes de tudo, devemos ter em vista que a análise da música da Barquinha difere-se, obviamente, da análise de uma obra de Beethoven por exemplo. Isto por vários motivos, mas, sobretudo, por tratar-se de uma cultura musical de tradição oral. É possível dizer que o único elemento desta música que foi registrado é a letra das canções. Ao analisar uma sinfonia de Beethoven ou outra obra similar de tradição escrita, identifica-se na composição características que revelam o estilo da obra e de seu respectivo autor. O modo como construiu as frases melódicas, o encadeamento dos acordes, as questões referentes à sonoridade, harmonia, melodia, ritmo e etc. (JAN LA RUE, 1989). Por outro lado, ao analisarmos um hino da Barquinha, não temos de antemão a partitura escrita pelo compositor. Diante disto, recorri as recomendações de Seeger (2004):

A etnografia da música é a escrita sobre as maneiras que as pessoas fazem música. Ela deve estar ligada à transcrição analítica dos eventos, mais do que simplesmente à transcrição dos sons. Geralmente

\footnotetext{
${ }^{30}$ A despeito de como foi dito, ao final do capítulo 3, durante a investigação descobri que o CEDPM e o CEOCPE não possuem $100 \%$ destes hinos antigos.
} 
inclui tanto descrições detalhadas quanto declarações gerais sobre a música, baseada em uma experiência pessoal ou em um trabalho de campo. As etnografias são, às vezes, somente descritivas e não interpretam nem comparam, porém nem todas são assim. (p.239)

Em campo, observei que não existe uniformidade nas performances musicais das igrejas da Barquinha. Um mesmo salmo pode ser executado com elementos musicais diferentes pela equipe de músicos de cada comunidade. Creio eu que cada Centro implementa as suas preferências estilísticas na execução deste repertório. Para demonstrar na prática o que afirmo aqui, coloco a seguir duas transcrições do salmo Cruz Bendita, que fiz a partir de gravações de áudios coletados em campo. A primeira partitura é referente ao CEDPM e a segunda ao CEOCPE, em seguida, um trecho da mensagem do referido cântico.
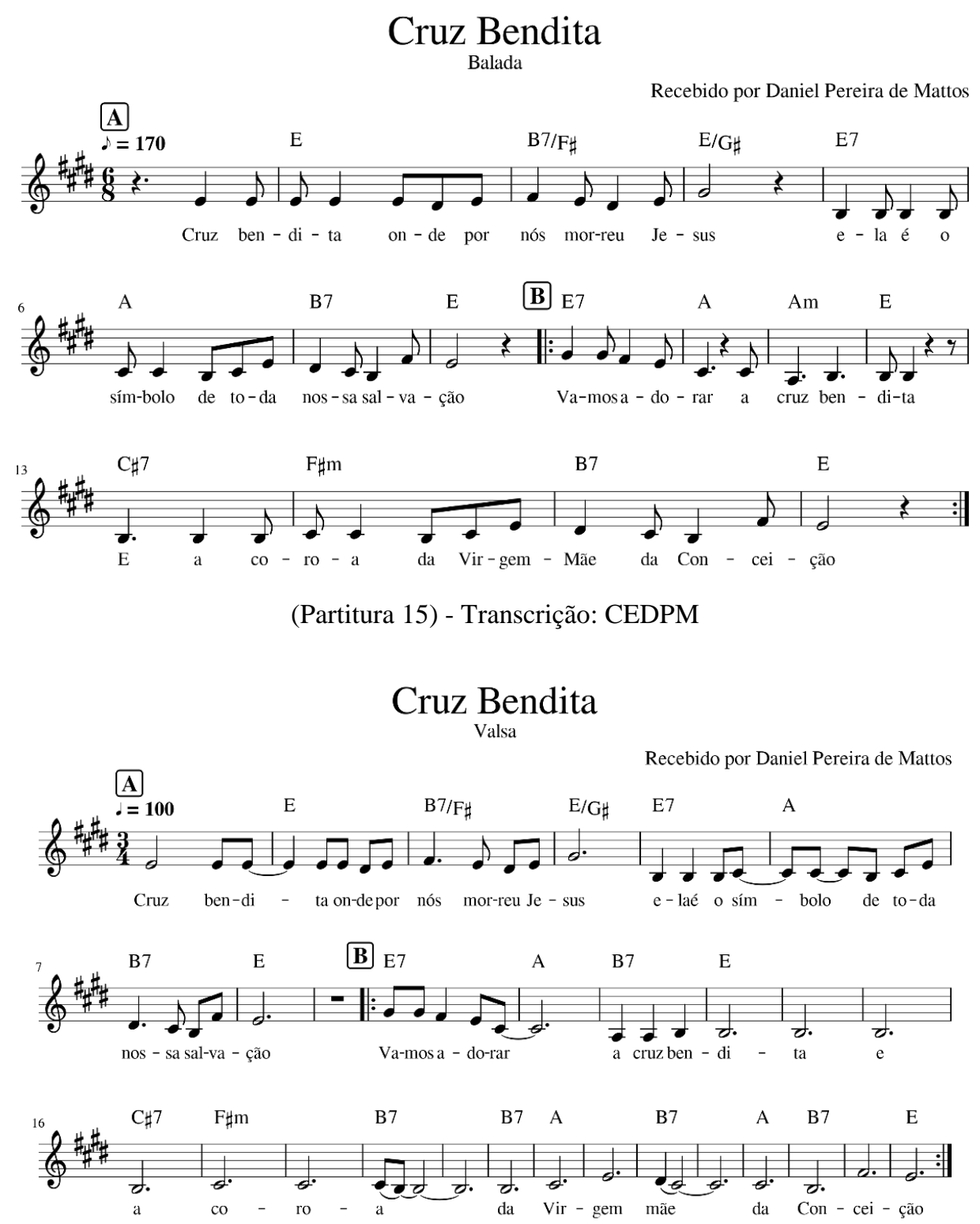

(Partitura 16) - Transcrição CEOCPE 
Cruz Bendita onde por nós morreu Jesus

Ela é o símbolo de toda nossa salvação

Vamos adorar a Cruz Bendita

E a Coroa da Virgem Mãe da Conceição

A Cruz Bendita que Jesus Cristo carregou

Para o seu calvário, foi pela nossa salvação

Vamos adorar a Cruz Bendita

E a Coroa da Virgem Mãe da Conceição

Bis

Este hino é cantado nas três igrejas da Barquinha que estão sendo abordadas nesta pesquisa. Infelizmente, não tive acesso às gravações de áudio no CECOCJFL para incluir nesta análise. Observei que o contorno melódico deste salmo é praticamente igual, comparando os dois exemplos acima. Entretanto, em cada caso as notas estão organizadas de modos distintos entre os compassos.

As performances que ocorrem nas diversas comunidades ligadas à missão religiosa de Daniel Pereira de Mattos revelam estilos diferenciados adotados por cada igreja. Diante disto, fica difícil definir o estilo dos compositores dos hinos antigos, que são comuns às três igrejas, pois não temos certeza se as características percebidas no ato da audição dos hinos pertencem de fato ao estilo dos seus respectivos autores, já que não deixaram suas obras registradas em partituras.

A seguir, analiso outro salmo antigo cantado nas igrejas da Barquinha. "Romaria dos Missionários" é um hino recebido por Mestre Antônio Geraldo na época em que ele presidia o CECOCJFL. Coloco adiante um trecho da letra e duas transcrições feitas com gravações de áudios coletados em campo.

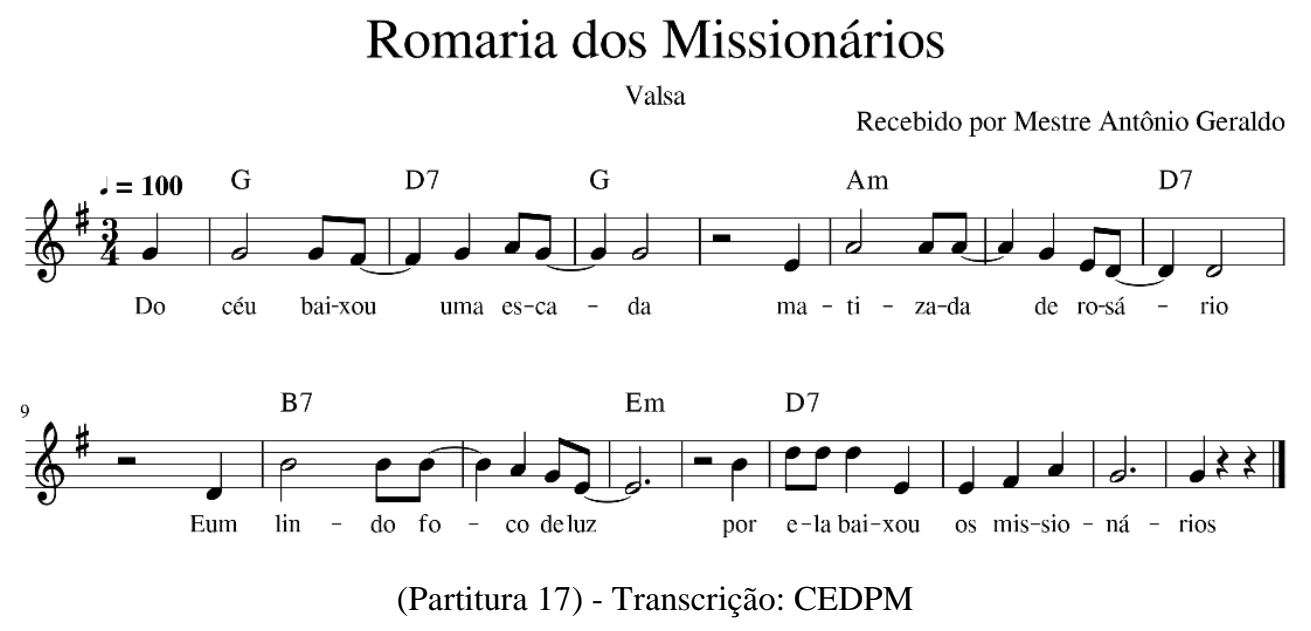


Do céu baixou uma escada

Matizada de rosário

E um lindo foco de luz

Por ela baixou os Missionários

Foi o Santo Frei Virgílio

Que Deus o fez de portador

Trazer este salmo santo

De luz firmeza paz e amor

\section{Romaria dos Missionários}

Bolero
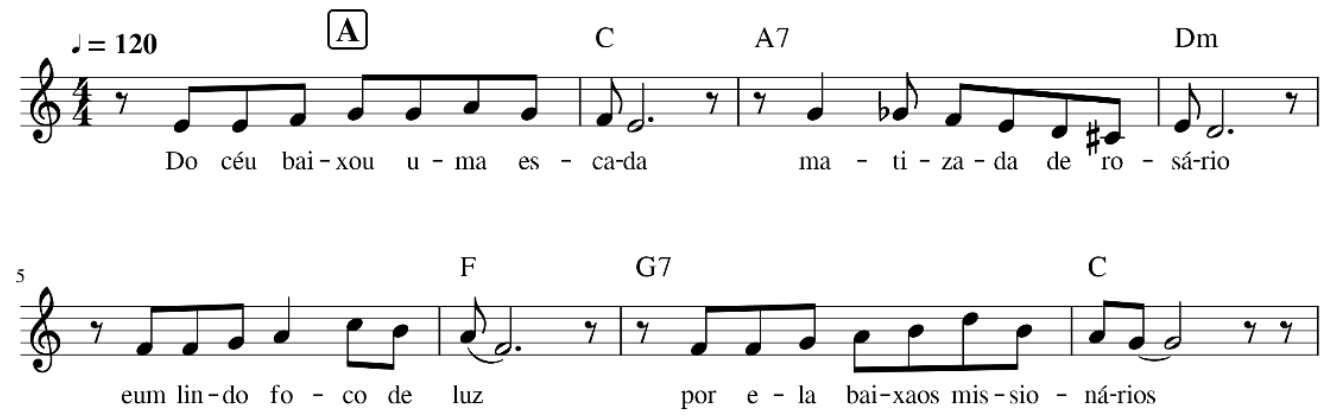

B
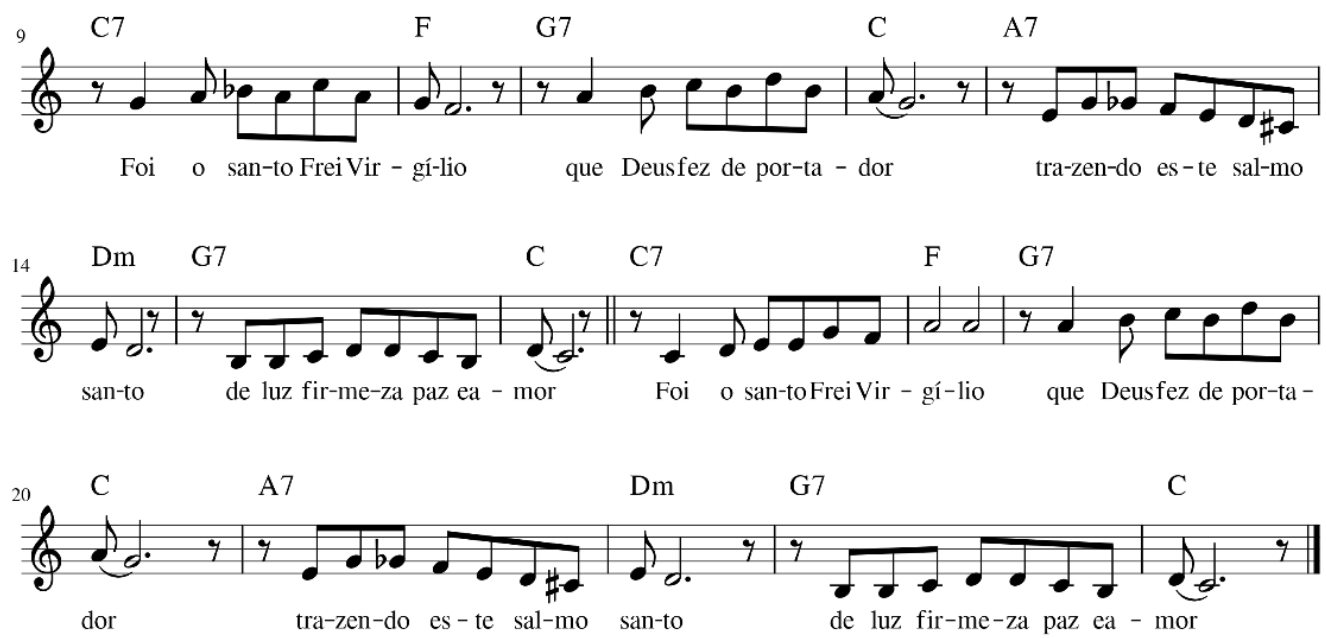

(Partitura 18) - Transcrição: CEDPM

Do céu baixou uma escada

Matizada de rosário

E um lindo foco de luz

Por ela baixa os Missionários

Foi o Santo Frei Virgílio

Que Deus o fez de portador

Trazendo este salmo santo

B - 2x

De luz firmeza paz e amor 
Neste caso analisado, trata-se de um mesmo hino, da mesma mensagem, ainda que conforme registrado nas partituras, a música seja totalmente diferente. Para entender a causa disto, precisei recorrer à transcrição analítica dos eventos (SEEGER, 2004), ou seja, investigar e entender os fatos que desencadearam esta situação. Em entrevista, Antônio Geraldo da Silva Filho (CEDPM) relatou-me que primeiramente seu pai recebeu este hino no CECOCJFL com o formato demonstrado no primeiro exemplo (partitura 17). Posteriormente, já no CEDPM, ele teria recebido uma música nova para "moldurar" a mensagem do salmo em questão (partitura 18). O entrevistado contou ainda que, tanto para seu pai, quanto para ele próprio, semelhante ocorrência é bastante comum, a saber, o recebimento de inspirações referentes a arranjos musicais para adornar estes cânticos religiosos.

A impressão que fica, é que no contexto da Barquinha os cânticos deste repertório representam composições vivas, e ao mesmo tempo, inacabadas. Mensagens religiosas, cuja métrica da melodia, harmonia e sonoridade, são elementos passíveis de serem interpretados de um modo diferente em cada comunidade desta tradição cultural.

\subsubsection{Gênero}

$\mathrm{Na}$ falta de um referencial já consolidado para designar os gêneros musicais capazes de classificar a música abordada aqui, precisei localizar a Barquinha no tempo e no espaço, a fim de traçar alguns caminhos possíveis para isso. É sabido que Daniel Pereira de Mattos (1988 - 1958) tinha experiência como músico e era reconhecido como um boêmio na capital acreana, cidade onde viveu a maior parte de sua vida. De sua autoria, foram encontradas partituras de canções de gênero instrumental, como por exemplo: Lydia (Valsa), Deixa-me tranquilo (Choro), Getúlio Vargas (Marcha), entre outras peças. 

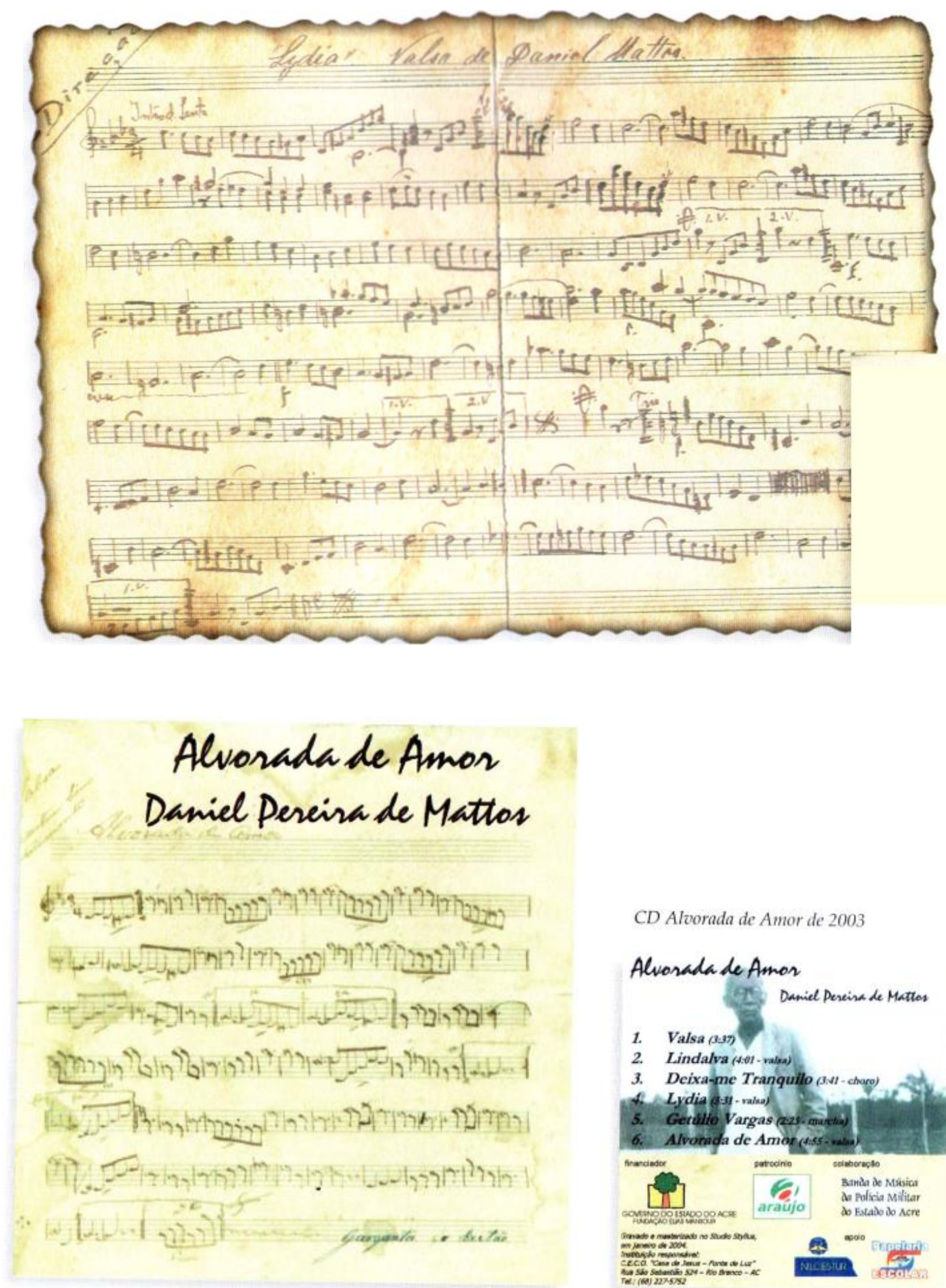

CD Alvorada de Amor de 2003

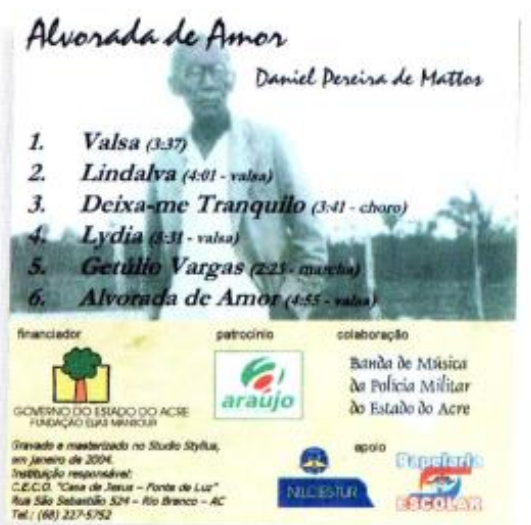

Fotos 17, 18 e 19 - Acima, partitura da Valsa Lydia, composta por Daniel Pereira de Mattos na década de 40, abaixo à esquerda, partitura da Valsa Alvorada de Amor, canções que fizeram parte do CD produzido pelo CECOCJFL, com os temas compostos por Daniel. Fonte: (org. ARAÚJO NETO, et. al., 2010).

Contudo, é preciso enfatizar que o nosso objeto de estudo é a música que surgiu no seio da doutrina religiosa fundada por Daniel Pereira de Mattos, cujo repertório é o conjunto de cânticos que ele e os seus discípulos receberam e ainda recebem desde o 
início da missão (1945) até os dias atuais. Estou analisando estes hinos, salmos, benditos e pontos que são executados nas diversas comunidades da Barquinha. É uma música vocal (cantada), de caráter estritamente religioso (cristã), que atende à liturgia dos rituais das igrejas ligadas à doutrina de Frei Daniel.

Rosana Martins de Oliveira (2002), em sua dissertação de mestrado em Filosofia e Ciências Humanas, investigou as origens da doutrina de Frei Daniel. Em sua pesquisa, coletou informações que descrevem o contexto histórico da migração de nordestinos ao Acre. Segundo a autora, a Barquinha é fruto de um catolicismo popular praticado pelo povo do Nordeste brasileiro cuja manifestação religiosa se dava na:

(...) capelinha de estrada, amostra mais cotidiana do povo, com suas festas, rezas, ladainhas e terços. Espaço comunitário, coletivo, congregacional, com calendário de festas em dias santificados, romarias, cânticos, tendo à frente o capelão, que ergueu, consagrou e fez um altar para colocar o santo padroeiro e outros santos da sua devoção, da sua tradição. Ele mora próximo a ela, zelando e promovendo os encontros, não pediu licença à matriz para criá-la, mas foi legitimado pelo povo, não é reconhecido pelos clérigos, é um leigo, mas o povo confia nele, se confessa e respeita, pede conselho e batismo, é o padrinho e amigo, os laços de confiança e sociabilidade eram estreitados nas necessidades cotidianas. (p.25)

A exploração das terras acreanas atraiu nordestinos e exploradores de outras regiões do Brasil (...) foi nesse contexto que os migrantes nordestinos tiveram contato com as populações indígenas, experimentando e se apropriando de elementos da sua cultura, em particular, o uso da Ayahuasca. (p. 44-46)

Portanto, um novo "altar" de crenças foi erguido na cidade de Rio Branco, não dentro da Igreja Católica ou Protestante, mas em casas e capelinhas que foram levantadas na beira das "estradas" de seringa. (p.59)

À margem do domínio de uma religião oficial, novas expressões de religiosidade se constituíram na cidade de Rio Branco, com ritual e normas de conduta particulares, com características apreendidas dos saberes da cultura indígena e da herança material e religiosa desses homens e mulheres nordestinos ou acreanos. (...) Assim como Raimundo Irineu Serra, Daniel Pereira de Mattos constituiu uma expressão religiosa na cidade de Rio Branco a partir de sua experiência com o Daime que culminou com a criação da Capelinha de São Francisco (Barquinha), espaço onde desenvolveu uma forma própria de apreensão do sagrado, com elementos que serviram de base para agregar homens e mulheres em suas experiências religiosas fora do controle da Igreja Católica. (p.60)

É dessa herança material e religiosa das pessoas que fundaram e consolidaram a Barquinha que podemos reconhecer a essência musical desta tradição cultural contida nos versos melódicos dos hinos, salmos, benditos e pontos. Nas mensagens destes cânticos encontramos expressões regionais como: "alumia", "salvemos", "altêia", 
"arrodêia", e etc., assim como personagens do universo religioso popular nordestino, a exemplo de: São Francisco das Chagas, São José do Arribamar, São Severino dos Ramos, Padre Cícero Romão, Frei Vidal da Penha, Frei Damião, Frei Virgílio, entre outros.

No campo das artes musicais, de um modo geral, não existe um consenso com respeito ao conceito de gênero e estilo. Uma referência sobre estes temas está no verbete "genre" do dicionário "Musicology: the key concepts", Beard e Gloag (2005):

$\mathrm{O}$ gênero necessariamente constrói um conjunto de códigos e expectativas e, portanto, pode ser entendido como algo imposto à música pelas culturas musicais (...), influenciando a maneira como a música é escrita. Por exemplo, compositores e músicos populares costumam tocar com convenções de gênero e isso é potencialmente útil para musicólogos, considerando a possibilidade de significado na música. Compreender o gênero também sugere maneiras de ouvir. Segundo o etnomusicólogo William Hanks, quando visto como uma interação entre construções sociais e conteúdo musical, o gênero pode oferecer (1) uma estrutura que um ouvinte pode usar para se orientar; (2) procedimentos para interpretar a música; e (3) um conjunto de expectativas (Hanks 1987; ver também etnia). Uma confusão que, às vezes, pode surgir é a sobreposição entre os termos estilo e gênero, conforme encontrado na escrita musicológica. Allan Moore observou que, em geral, os estudos de música popular empregam o termo gênero, enquanto a escrita na música clássica tende, pelo menos até meados da década de 1980, a misturar gênero e estilo livremente (Moore 2001b). Desde meados da década de 1980, no entanto, os musicólogos tendem a usar o gênero para descrever os aspectos externos e socialmente condicionados de uma obra, e o estilo é reservado para a consideração das características internas formais. (p. $54)^{31}$

Partindo dos pressupostos indicados acima, arrisco aqui classificar a música da Barquinha, em sua forma mais ampla, como parte de um gênero ainda pouco abordado no mundo acadêmico: A Música Brasileira de Ayahuasca (LABATE e PACHECO,

31 Genre necessarily constructs a set of codes and expectations and therefore may be understood as something that is imposed upon music by musical cultures (see culture), influencing the way in which music is written. For example, composers and popular musicians will often play with genre conventions, and this is potentially useful to musicologists considering the possibility of meaning in music. Understanding genre also suggests ways of listening. According to ethnomusicologist William Hanks, when viewed as an interaction between social constructs and musical content, genre may be seen to offer (1) a framework that a listener may use by which to orient themselves; (2) procedures to interpret the music; and (3) a set of expectations (Hanks 1987; see also ethnicity). One confusion that may at times arise is the overlap between the terms style and genre as encountered in musicological writing. Allen Moore has noted that, in general, popular music studies employ the term genre, whereas writing on classical music tended, at least until the mid-1980s, to mix genre and style freely (Moore 2001b). Since the mid-1980s, however, musicologists have tended to use genre to describe the external, socially conditioned aspects of a work, and style is reserved for consideration of the formal, internal features (see analysis). 
2009). Creio que este seja um termo recente, ou seja, provavelmente não é um gênero reconhecido, particularmente na academia. Existem semelhanças entre o universo musical da Barquinha e o da doutrina ayahuasqueira fundada por Raimundo Irineu Serra, principalmente no que se refere ao conteúdo cristão das letras dos hinos e o modo como se dá o processo de criação do repertório destas tradições (o ato de receber hinos), entre outras similaridades. Tais particularidades foram apontadas pelo professor e maestro Mário Lima Brasil em texto que escreveu para a publicação intitulada: Mestre Daniel - Historia com a Ayahuasca, (MARGARIDO, ARÚJO NETO, 2005), sobre este gênero musical, ele diz:

A música do Daime (Ayahuasca), independente de qual linha seja, é uma música de tradição oral, cantada por um grupo e acompanhada por alguns instrumentos. Em alguns momentos, se interrompe o ritual para que todos bebam o Daime. Os hinos são "recebidos" das entidades superiores. Essa experiência, segundo alguns, se aproxima um pouco do insight como é conhecido na psicoterapia. Em geral, condensa uma espécie de visão ou abordagem sobre um determinado tema, invariavelmente invocando as forças positivas através dos símbolos específicos da linha do Daime. Pode conter mensagens transformadoras para o receptor ou para o grupo. Em síntese, a mensagem recebida através do hino pode significar correções de rumo, saudações, invocações, ensinamentos ou simplesmente festa (...). (p.64-65)

\subsubsection{Forma}

De um modo geral, ao analisar o repertório da Barquinha percebi que a forma é um elemento da composição que não varia muito no conjunto dos cânticos. É preciso ressaltar que dentre os três Centros que visitei em campo não existe uniformidade no que se refere aos elementos dos hinos antigos. No geral, a maioria das mensagens recebidas na Barquinha está distribuída em quadras. Podemos considerar que geralmente os dois primeiros versos representam a parte $\mathrm{A}$, enquanto os dois últimos a parte $\mathrm{B}$ (forma binária $\mathrm{AB}$ ). Quase sempre, o segundo verso da estrofe rima com o último, de modo que a melodia se repete em todas as estrofes. De acordo com Aaron Copland (1974):

A mais simples dessas formas é a forma em duas partes, ou binaria, representada por A-B. A forma binaria é pouco usada atualmente, mas teve um papel preponderante na música escrita entre 1650 e 1750 . (...) o fim da seção A é quase sempre indicado por uma barra dupla com um sinal de repetição. Algumas vezes o sinal de repetição é visto também no fim da seção $B$, quando a fórmula seria descrita mais exatamente corno sendo A-A-B-B. Mas, como eu já observei, ao analisar as formas costuma-se não levar em conta essas repetições 
exatas, porque elas realmente não ateiam a estrutura da música. Além disso, os intérpretes seguem o seu próprio critério quando se trata de executar ou não as repetições indicadas. (p.40)

De fato, o que o autor diz acima a respeito das repetições ocorre na Barquinha. Em campo, observei que cada Centro pode executar, ou não, as repetições entre as partes. No CEOCPE, por exemplo, é mais comum a forma AABB. Já no CEDPM, o modo mais recorrente é ABB. Ao que tudo indica, isto se deve às escolhas particulares de cada centro. Exponho abaixo a análise de um hino do repertório da Barquinha, relembrando que, geralmente, as partituras dos hinos que coloco aqui são o resultado das transcrições de gravações de performances musicais no CEOCPE:

\section{Soldado de Ordem \\ Valsa}

Recebido por Daniel Pereira de Mattos
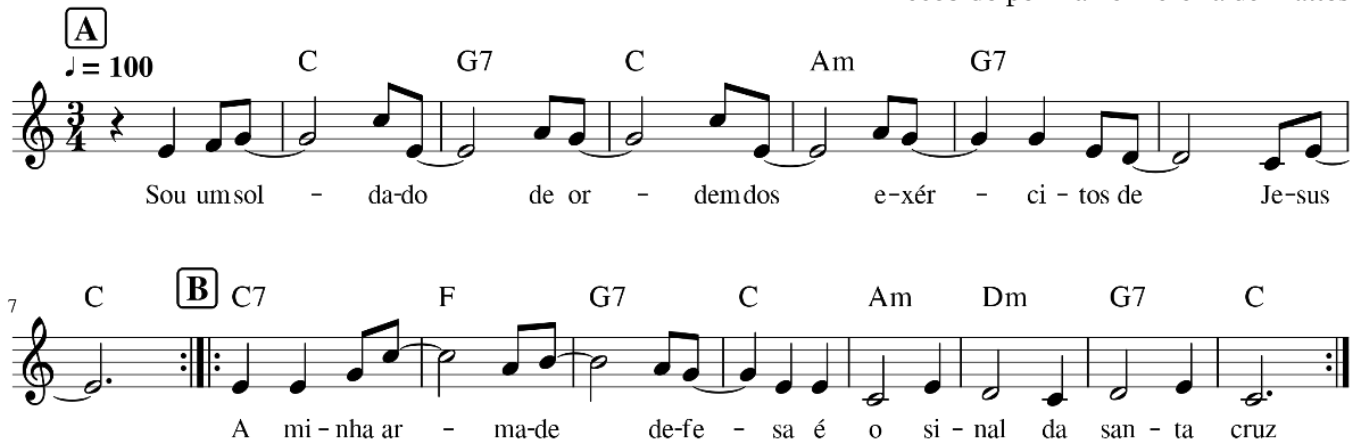

(Partitura 19)

Sou um soldado de ordem

Dos exércitos de Jesus

Bis (A)

A minha arma de defesa

É o sinal da santa cruz

Bis (B)

Sou soldado em penitência

Pois também fui pecador

Bis

Tenho instruções nesta luz

Quem me vem do Criador $\}$

Bis

O meu fardamento é a fé

E o meu escudo é o clarão

Bis

Do sagrado olhar de Deus

E da Virgem da Conceição

Bis

Deus me livre das misérias

E das malignas tentações Bis

Deus me livre em ser ferido

Ou eu ferir aos meus irmãos

Bis 
Este hino faz parte da coroa de hinos denominada de "abertura", cantada no início dos cultos da Barquinha. Escolhi ele para representar esta forma AB tão comum nos salmos da Barquinha. Geralmente, a execução destes hinos ocorre da seguinte maneira: o cantor, ou cantora solista (puxador) canta os três primeiros versos, enquanto o coro (todas as pessoas presentes no culto) responde cantando o último verso. Ao comparar este hino entre os Centros pesquisados neste trabalho, verifiquei as seguintes variações: no CEDPM a forma utilizada é ABB. Encontrei pequenas variações na letra, por exemplo: "tenho instruções nesta luz, que nos vem do Criador." Além disso, no CEDPM outra fórmula de compasso é utilizada, a quaternária. Apesar dos esforços, não obtive acesso às gravações do CECOCJF para efetuar a análise comparativa do hino em questão.

Outra modalidade, muito recorrente na Barquinha é quando um hino possui um refrão que deve ser cantado por todos que estão na igreja (coro). O refrão, frequentemente, tem uma melodia diferente das demais estrofes, porém, existem muitos hinos em que o refrão e as estrofes têm a mesma melodia. A seguir, coloco exemplos que representam o que foi dito acima:

\section{As obras de Deus
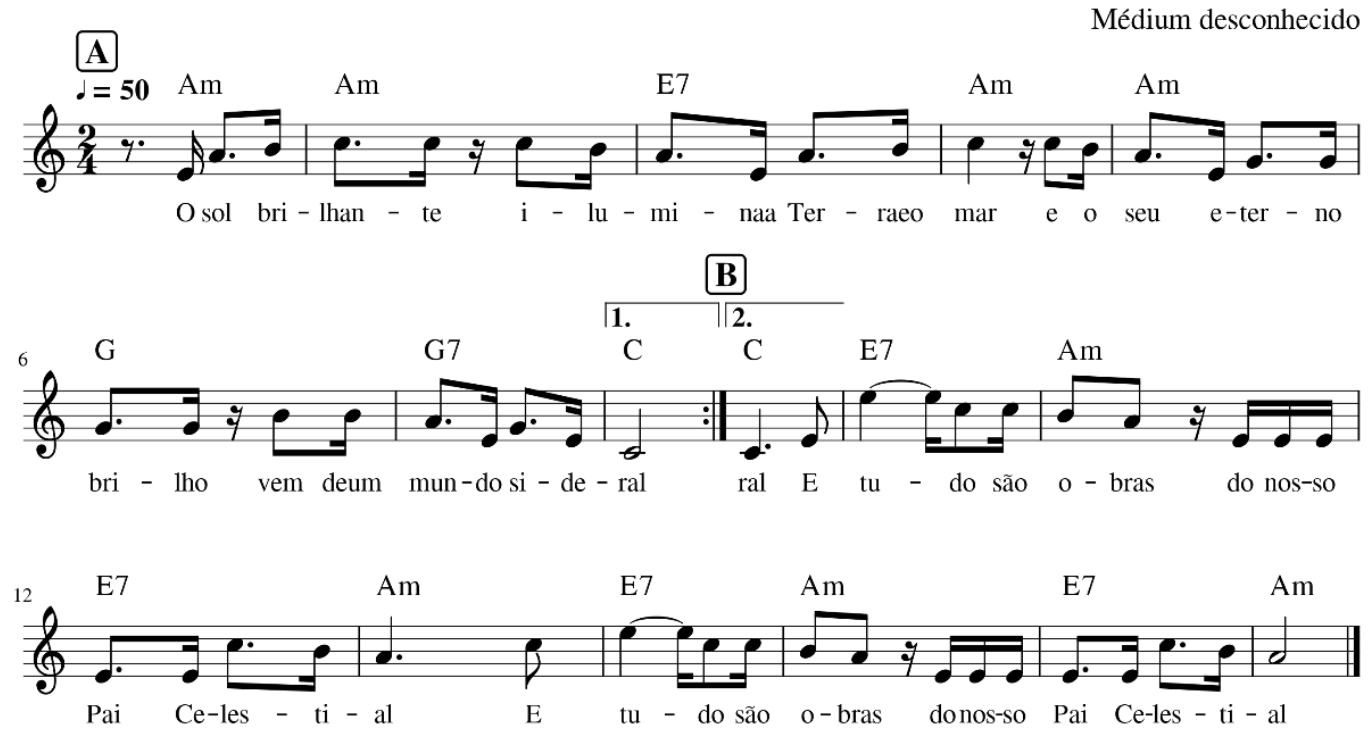

(Partitura 20)

O sol brilhante ilumina a Terra e o mar

E o seu eterno brilho vem do mundo sideral $\}$

E tudo são obras do nosso Pai Celestial

E tudo são obras do nosso Pai Celestial
Bis (A)

Refrão (B) 
A lua e todas as constelações sagradas Rebrilham com harmonia por todo mundo astral

E tudo são obras do nosso Pai Celestial

E tudo são obras do nosso Pai Celestial

Bis

Ao contemplar as santas maravilhas As obras do grande Mestre, sublime e divinal Bis Salvemos com amor ao nosso Deus Celestial Salvemos com amor ao nosso Deus Celestial Refrão

O hino acima, transcrito do acervo do CEOCPE, está no formato AAB, sendo que o solista canta a parte A e o coro a parte B. Ao comparar a transcrição acima (CEOCPE) com o modo como o hino é executado nos outros Centros, notei que no CEDPM utiliza-se a fórmula de compasso 6/8, em ritmo de balada. Naturalmente, as células melódicas e a prosódia se comportam de um modo um pouco diferente do que está transcrito acima. Já no CECOCJFL, constatei que a parte A não se repete (forma $\mathrm{AB})$. Abaixo exponho um trecho de outro hino:

\section{$\underset{\text { Foxtrot }}{\text { Troco Troco }}$}

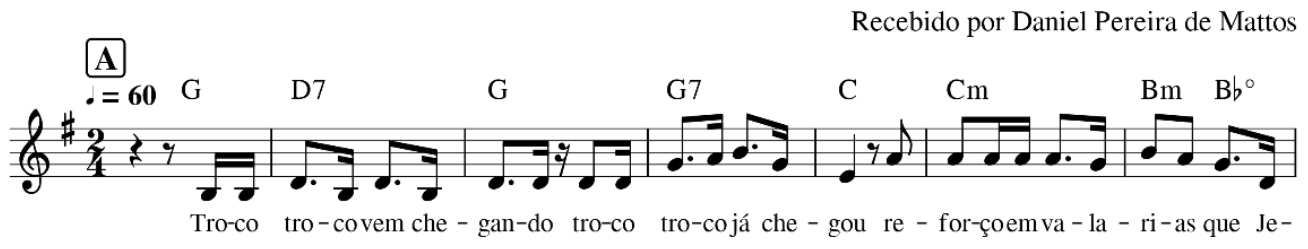

B
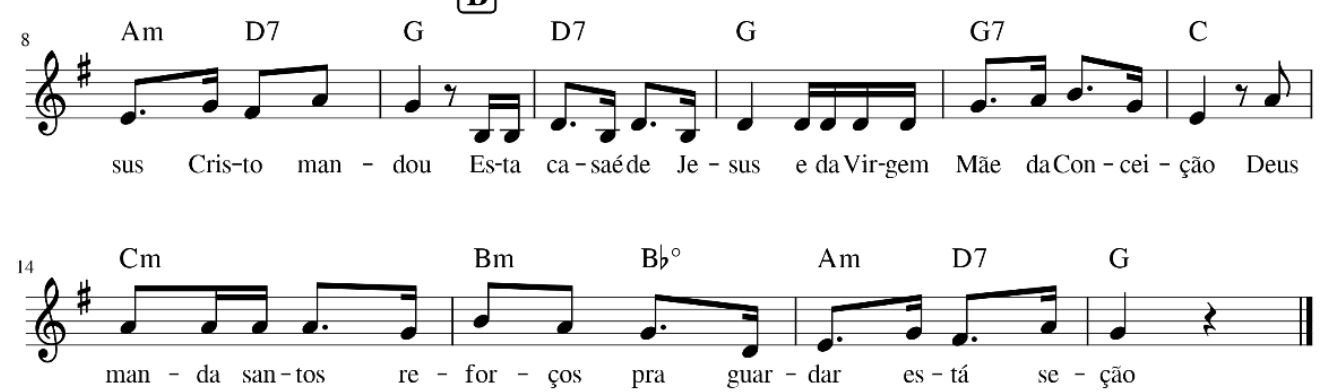

(Partitura 21)

Troco troco vem chegando

Troco troco já chegou

Reforço em cavalarias

Que Jesus Cristo mandou

Esta casa é de Jesus

E da Virgem Mãe da Conceição

Deus manda santos reforços

(B)

Pra guardar esta seção 


\section{São Jorge e São Gabriel}

São os sagrados guardiões

De Jesus nosso Senhor

E da Virgem da Conceição

Por questões metodológicas estou considerando que, quanto à forma, este exemplo é semelhante ao hino anterior, em que o solista canta uma parte (neste caso a parte B) e o coro canta o Refrão (neste caso a parte A). A diferença é que a melodia da parte $\mathrm{A}$ é igual à melodia da parte $\mathrm{B}$. Enfatizo aqui que, em todos os hinos, geralmente, ocorrem pequenas variações no ritmo e na métrica da melodia, de acordo com o texto de cada estrofe.

Quanto à forma dos cânticos da Barquinha, em campo, não encontrei outros exemplos muito diferentes dos que expus nesta seção. Ainda assim, há que se deixar claro que as partituras que elaborei e foram aqui inseridas são uma transcrição do pesquisador. Portanto, correspondem à forma como interpretei e pensei a música que ouvi durante a investigação, particularmente no que diz respeito ao método que utilizei para demonstrar a questão da forma destes cânticos.

\subsubsection{Melodia}

Quanto à melodia dos salmos da Barquinha, notei que na utilização das escalas e arpejos, saltos intervalares menores são frequentes (intervalos simples). Não encontrei no repertório observado, outros tipos de escala além da escala natural maior e menor, e a escala menor harmônica. Geralmente, a tessitura dos hinos não excede a um intervalo de décima. Segue abaixo um trecho de um hino que representa bem as características apontadas neste tópico da análise.

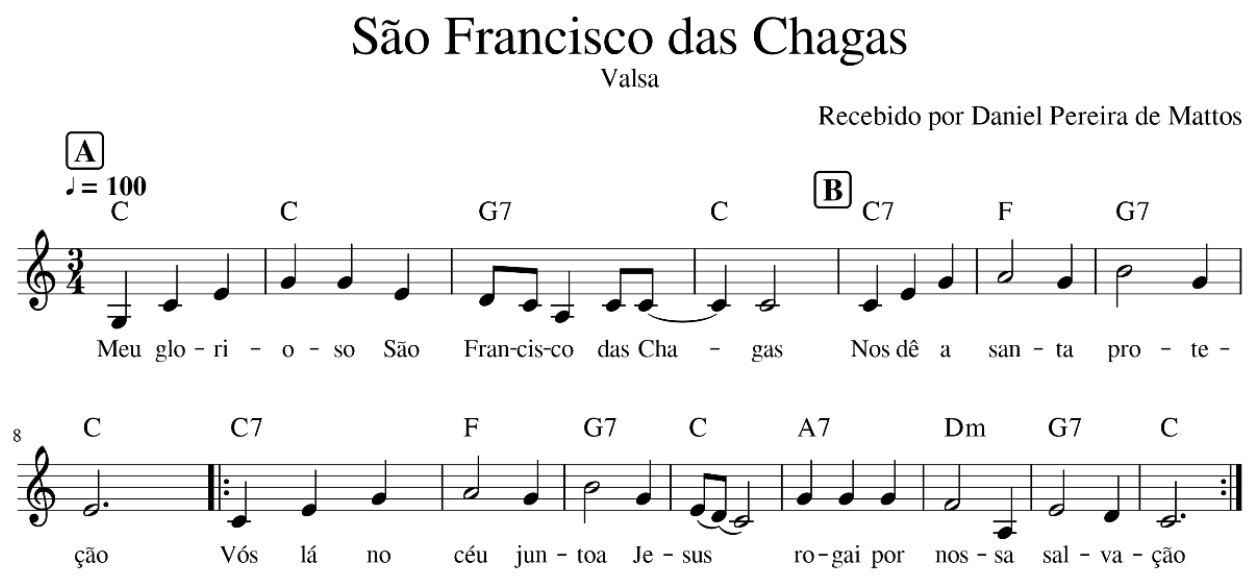

(Partitura 22) 
Meu glorioso São Francisco das Chagas

Nos dê a santa proteção

Vós lá no céu junto a Jesus

Rogai por nossa salvação $\}$ Bis

Meu glorioso São Francisco das Chagas

Nos livrai das perseguições

Seja vós nosso advogado

Fora e aqui nesta seção $\}$ Bis

Meu glorioso São Francisco das Chagas

Nos dê a vossa santa benção

Testificai pelo mundo inteiro

A verdade santa desta seção $\}$ Bis

Nas performances dos cantores do CEOCPE, foi possível observar, pequenas variações no que tange a questão da prosódia dos salmos cantados, ou seja, existe uma certa flexibilidade quanto à execução destes cânticos, de modo que cada cantor pode imprimir ali o seu próprio estilo, logicamente, sem alterar muito o resultado final, comparando-se as performances. Em campo, observei também que as melodias dos hinos antigos podem variar um pouco de uma igreja para outra. As causas prováveis disto é o fato destas melodias não terem sido registradas em partitura, aliada ao histórico de dissidências da Barquinha, de modo que, ao longo da trajetória desta tradição oral, estas variações melódicas inevitavelmente ocorreram.

No momento da transcrição de alguns áudios fornecidos pelo CEOCPE, me deparei com uma situação interessante. Em alguns casos, fiquei em dúvida com passagens em que a melodia indicava uma escala natural menor, enquanto a banda harmonizava a seção com um acorde dominante, resultante da alteração ascendente do sétimo grau, conforme ocorre no compasso 10 do exemplo a seguir:

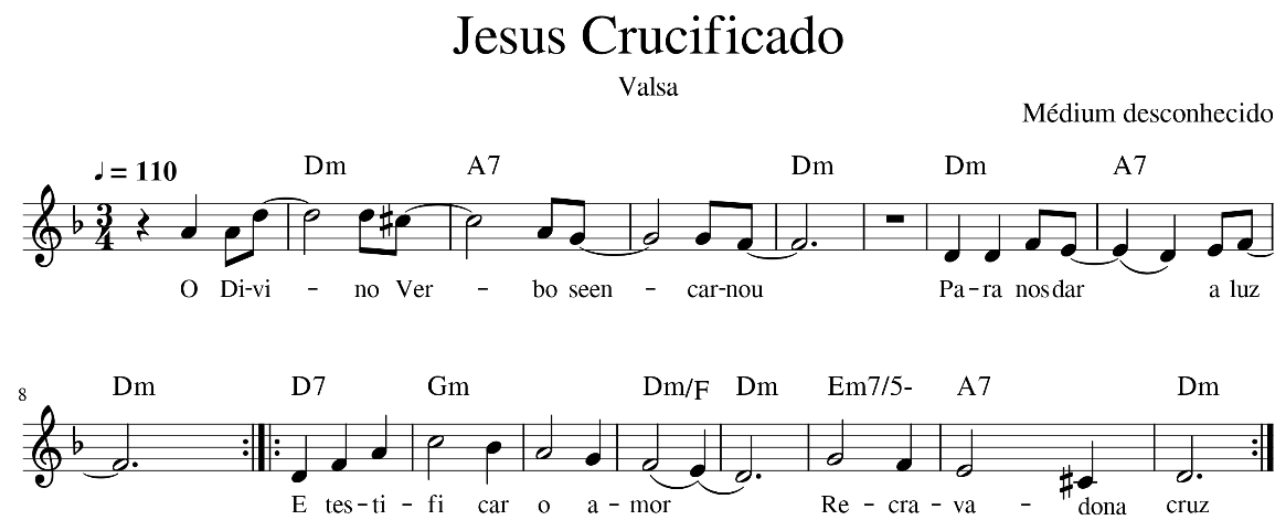

(Partitura 23) 


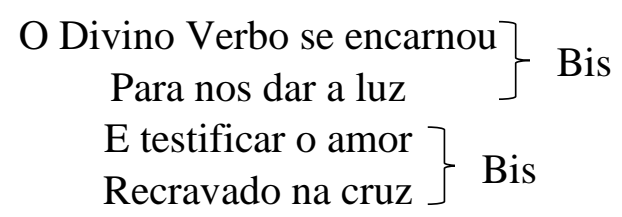

Neste caso, embora a melodia seja um arpejo de ré menor (ré, fá e lá), o acompanhamento harmônico executa um acorde de ré maior com sétima menor. Como não existe a partitura original como referência, no trecho em questão, fica a dúvida se a melodia deveria executar um fá sustenido ao invés de fá natural, ou se o acorde deveria ser um ré menor, ao invés de um ré com sétima, ou, se de fato seja a intenção do compositor fazer soar um acorde de ré com sétima e nona aumentada (D7/\#9). Identifiquei situações semelhantes a esta em outros hinos analisados.

\subsubsection{Acompanhamento rítmico-harmônico}

Como disse anteriormente, a melodia e a letra são os elementos principais da música aqui analisada. Ainda que secundário, o acompanhamento tem a função primordial de enriquecer a performance musical. Opinião semelhante, encontrei no texto de Paula Faour (2006):

Segundo o Dicionário Grove, acompanhamento significa, "de um modo geral, as partes secundárias (subordinadas) em uma textura musical." Tais definições procedem em parte. As palavras usadas pelo Dicionário Grove, secundária e subordinada, nivelando o acompanhamento como posição inferior, ou menos importante, não são pertinentes para a definição, mesmo que o acompanhador tenha a incumbência de prover base musical para um solista, seja ele vocal ou instrumental. Apesar do solista estar em destaque, entende-se que o acompanhador tem o poder de influenciar, e até mesmo transformar, induzir ou mudar a interpretação de um solista. (p. 65)

O acompanhamento rítmico-harmônico da música da Barquinha é uma questão que merece uma atenção especial aqui. Primeiramente, como já foi dito, este acompanhamento, no geral, é um elemento que não foi registrado em partitura. Ao contrário da melodia principal, estes outros elementos musicais (harmonia, ritmo, som) são essencialmente mais maleáveis, o que permite aos músicos da Barquinha investir na criatividade musical individual, e na prática do arranjo em conjunto.

De um modo geral, os rituais musicalizados da Barquinha se apresentam basicamente de duas formas: o culto e as festas. No primeiro caso, os cultos dentro do templo representam a forma mais comum, quando a irmandade se senta ao redor de uma 
mesa em forma de cruz. Cada culto tem um significado e um objetivo de acordo com o calendário ritualístico de cada comunidade da Barquinha. Por exemplo, datas comemorativas de algum santo cultuado na casa, Natal, entre outras. Além disso, há os cultos "normais" que acontecem ao longo do ano, por exemplo: os cultos de instrução às quartas-feiras, as Obras de Caridade, aos sábados, entre outros. Para cada seção existe uma seleção de hinos adequada para cada ocasião. Uma pessoa, o puxador, conduz a execução do cântico do hinário, enquanto os demais membros presentes entoam o coro ${ }^{32}$ em uníssono e os músicos fazem um acompanhamento rítmico-harmônico. Cada hino cantado é sucedido de uma prece e uma antífona. ${ }^{33}$

A segunda forma são os rituais festivos, conhecidos como "Bailado", momento em que são cantados os pontos para os médiuns bailarem irradiados pelas entidades que compõem o panteão da Barquinha. A banda musical se posiciona num palco ou coreto, enquanto os participantes bailam, girando em torno do salão. O repertório aqui também varia de acordo com a ocasião.

Entre as diversas comunidades da Barquinha, os estilos musicais variam bastante. Acredito que a equipe de músicos que atua em cada igreja geralmente tem grande parcela de responsabilidade no que se refere à formalização das características estilísticas de cada grupo. Em campo, tive acesso a vídeos e gravações antigas. Foi possível fazer uma viagem, no tempo, e observar performances diversas nas três igrejas da Barquinha em períodos anteriores, que demonstraram o que sustento aqui. Ademais, os relatos dos entrevistados também confirmaram isso. Descrevo abaixo as impressões do pesquisador acerca de algumas características estilísticas percebidas nas performances musicais de cada Centro, no período do trabalho de campo.

Nos cultos do CECOCJFL, os quais tive a oportunidade de participar e observar a performance musical, o que mais nos chamou a atenção foi a boa capacidade de organização da banda diante da diversidade de timbres e a quantidade de membros que participam do conjunto musical. Bem entrosada, a equipe de músicos demonstrou uma boa capacidade de manipulação de elementos musicais, como a dinâmica do som durante a execução dos hinos. Identifiquei os seguintes instrumentos sendo utilizados no

\footnotetext{
32 Pode ser um trecho do hino, geralmente o último verso ou em alguns casos um refrão que se repete a cada estrofe cantada.

${ }^{33}$ Isto pode variar entre as comunidades. Por exemplo, no CEOCPE, reza-se apenas a prece, não se canta antífona, já no CEDPM, notei que nem todos os hinos são sucedidos por uma prece. Considera-se como uma prece, geralmente, um Pai Nosso e Ave Maria ou uma Salve Rainha, ou, um Credo.
} 
culto dentro do templo: contrabaixo elétrico, violão de nylon, violão de aço, cavaquinho, bandolim, sanfona, cajon, flauta transversal, além de 4 cantores (dois homens e duas mulheres) que se revezavam na função de "puxar" os hinos. Os ritmos que ocorrem com mais frequência são valsas (3/4) e o foxtrote $(2 / 4$ ou 4/4). Com relação à parte harmônica, observei que, no geral, emprega-se o uso da harmonia tonal, todavia foi possível notar durante a performance, alguns hinos com uma sonoridade modal. Além disso, notei a utilização frequente de acordes dissonantes durante nossa observação. No bailado do CECOCJFL é possível identificar características estilísticas do gênero musical nordestino. Prova disso é a utilização de instrumentos como a sanfona e a zabumba e de ritmos como o baião e o xote.
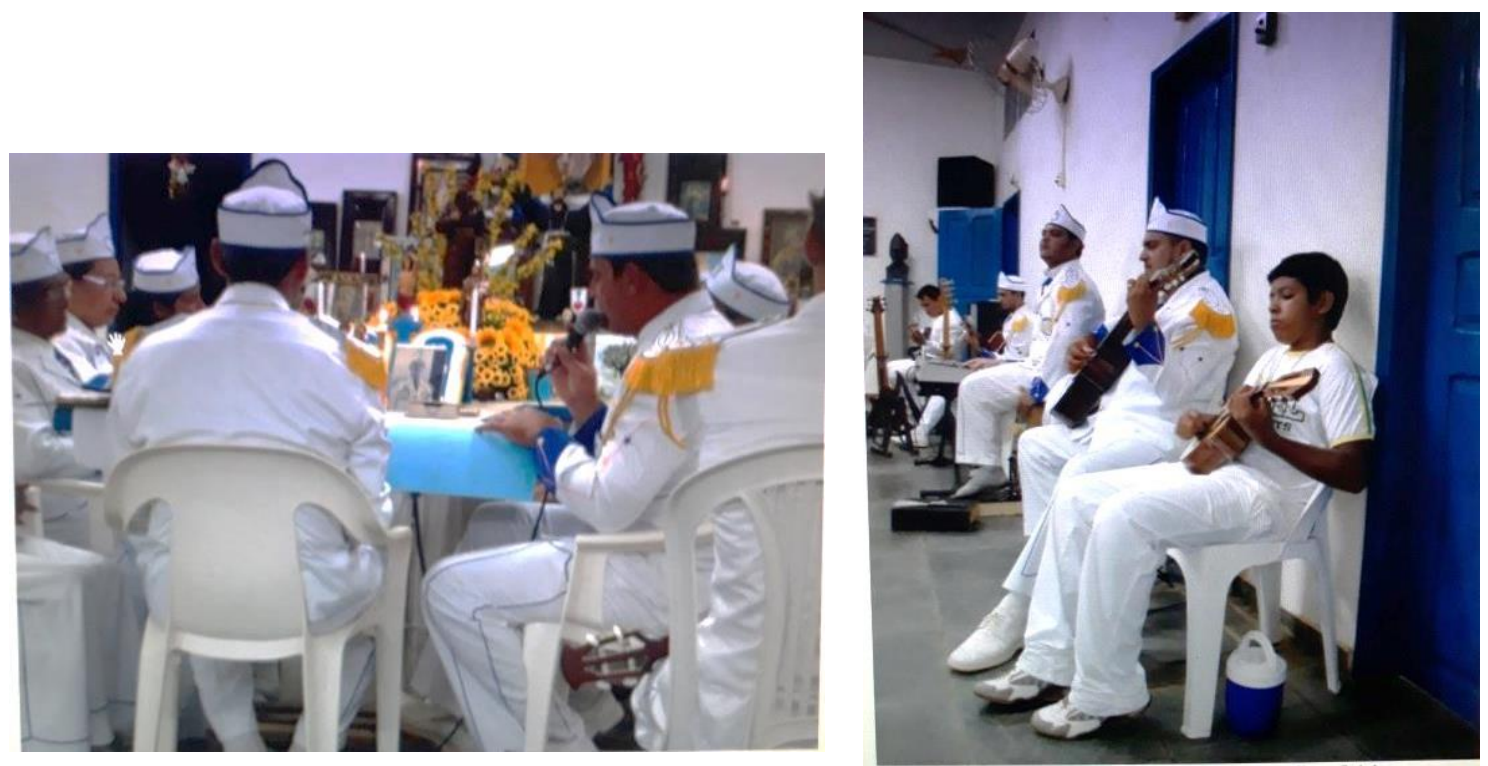

Fotos 20 e 21 - Cantores e músicos do CECOCJFL, em performances musicais durante cultos no interior do templo. (Fonte: MAGALHÃES, 2013)
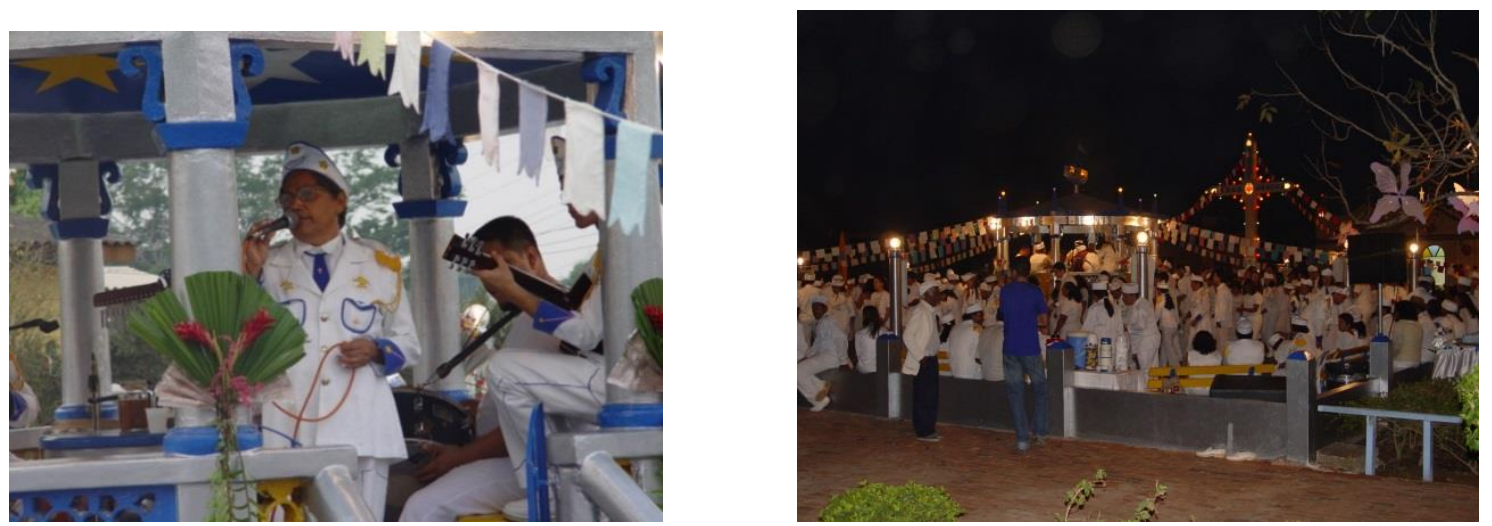

Fotos 22 e 23 - Músicos do CECOCJFL, em performances musicais durante bailados em rituais festivos. (Fonte: Acervo do CEOCPE) 
No CEDPM, observei que um teclado (sintetizador) é utilizado para produzir um playback com a maior parte dos timbres que compõe o acompanhamento rítmico harmônico (baixo, órgão, bateria, piano, entre outros sons, como cantos de passarinhos, e o "chuá" das ondas do mar, por exemplo). Nos cultos em que participei em campo, notei um integrante da banda tocando teclado e cantando, enquanto o presidente do Centro, Antônio Geraldo da Silva Filho executava seu violão. Ele é o cantor principal da Casa, e, na Barquinha, possui um estilo único de tocar seu instrumento, lembrando algumas vezes o estilo contrapontístico do violão de acompanhamento do gênero do choro e do samba consagrado pelo Mestre Horondino Silva (Dino 7 Cordas).

O CEDPM foi o local onde observei a maior quantidade de ritmos entre os Centros da Barquinha. Bolero e marcha (2/4 ou 4/4), valsas e guarânias (3/4), além da balada (6/8), esse último, inclusive, só vi ocorrer neste Centro durante toda a investigação. Quanto à harmonia, também impera o uso da harmonia tonal. Também é comum o uso de inversão de acordes, contracantos, substituições diatônicas, além do uso recorrente de dominantes secundários nos acordes do segundo grau dos encadeamentos harmônicos (I - II7 - V7). Nas festas, o teclado (sintetizador) é quem comanda ritmos como a marcha, o xote, o samba, as valsas que movimentam a irmandade que baila em círculo ao som dos pontinhos recebidos pelo Mestre Daniel e Mestre Antônio Geraldo.

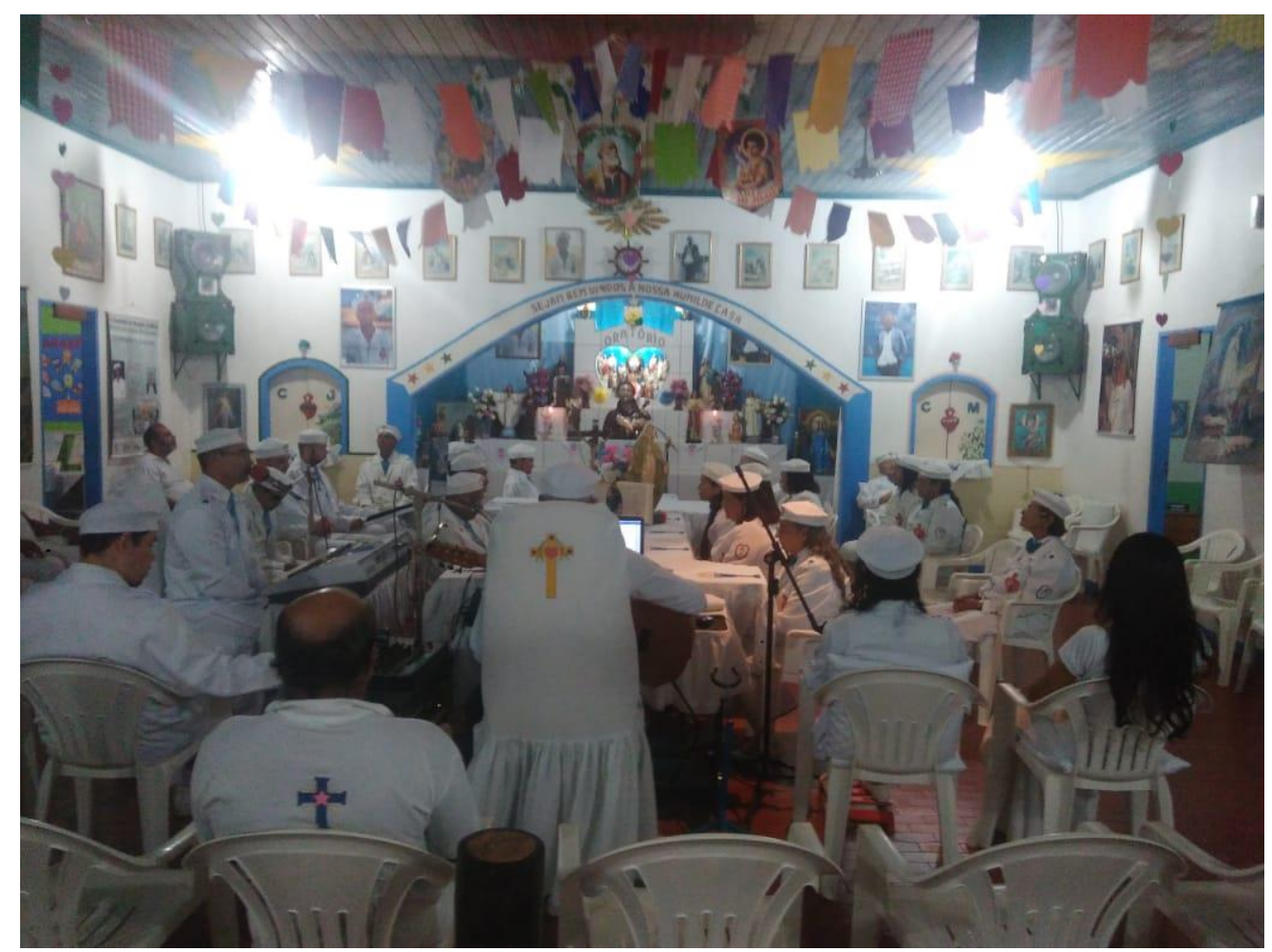

Foto 24 - Culto dentro do templo no CEDPM, no ano de 2019. (Fonte: Acervo CEDPM) 


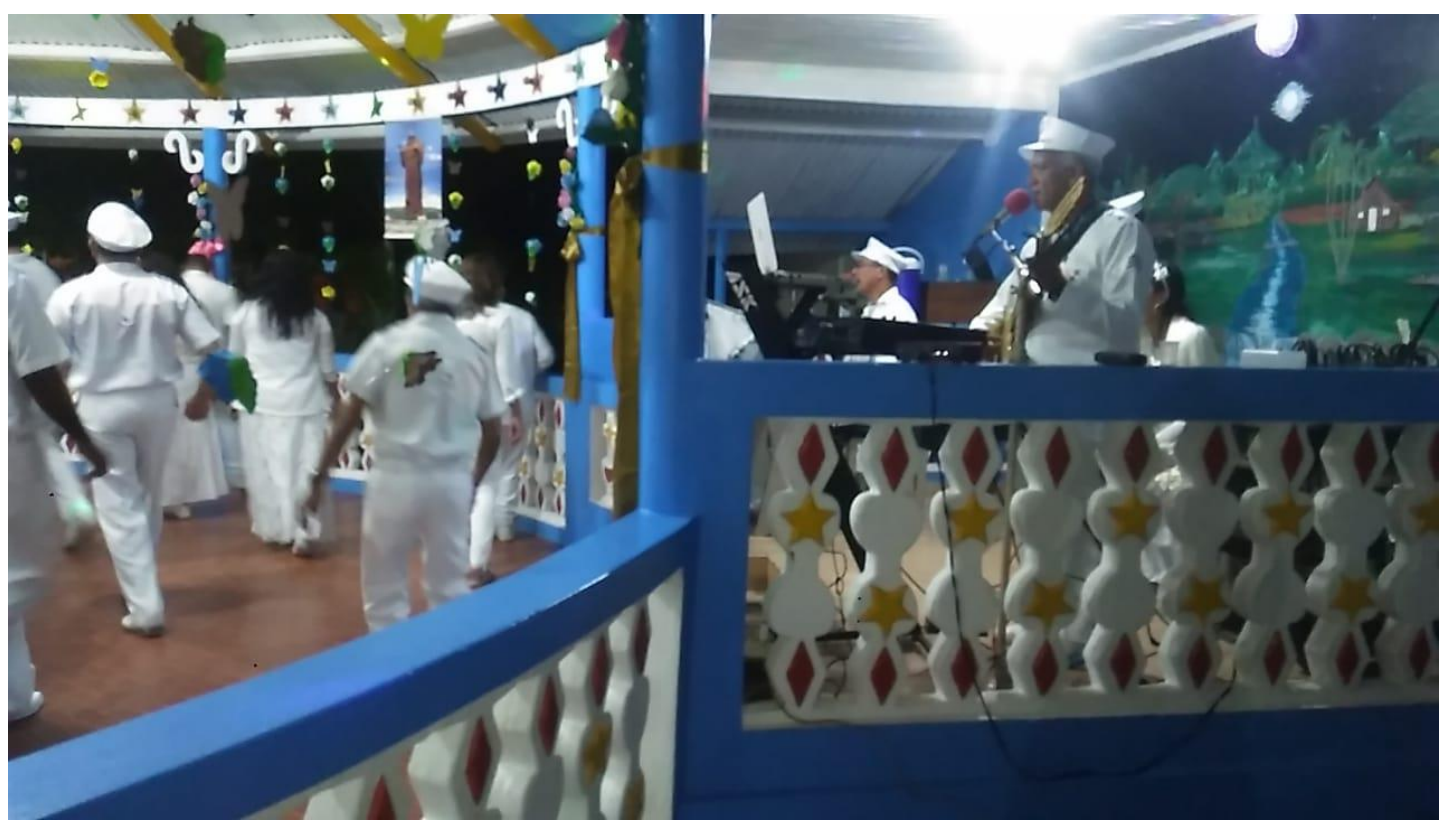

Foto 25 - Bailado no CEDPM, no ano de 2019. (Fonte: Acervo CEDPM)

O CEOCPE foi a comunidade em que passei a maior parte do tempo em campo. Foi também o local onde consegui acessar com mais facilidade documentos, vídeos e gravações de áudio. Diante disso, tornou-se possível visualizar boa parte da trajetória e do desenvolvimento da prática musical da comunidade. Obtive acesso a vídeos que mostravam o cotidiano do Centro desde o início de sua fundação (1991) até os dias atuais. Nos primórdios deste grupo, apenas o jovem João Batista (Joca), compunha a banda tocando um violão. Na cantoria, além do próprio Joca, sua mãe (Dona Chica Gabriel) e outros membros cantavam os hinos. Surpreendeu-me a forma de tocar a valsa que João Batista desenvolveu em sua prática no violão no início de sua trajetória musical no CEOCPE. Tal característica chamou a minha atenção uma vez que, ao que parece, trata-se de um estilo desenvolvido individualmente, pois não encontrei nada semelhante durante a pesquisa realizada dentro e fora da Barquinha. A célula rítmica que ele executava ao violão era a seguinte:

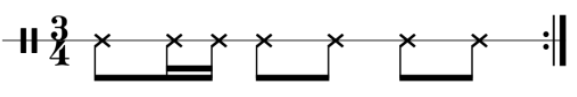

(Partitura 24)

Atualmente, o músico mudou seu estilo de tocar, absorvendo outras técnicas, outros estilos. Com o passar do tempo, novos músicos foram chegando na Casa. Hoje, são vários músicos que compõem a banda. Observei a presença de violões, contrabaixo, guitarra elétrica, flauta e cavaquinho, mas nunca a presença de instrumentos de 
percussão nos cultos dentro do templo. ${ }^{34}$ No que tange à harmonia utilizada para acompanhar as melodias dos cânticos, também impera o uso do modo tonal. Observei também o uso de alguns recursos como, por exemplo, inversão de acordes, substituições diatônicas e contracantos. Em campo, na entrevista com o músico Antônio (nome fictício), obtive o seguinte relato:

Antigamente, a gente usava mais as progressões (I - V7 - I); (I - IV$V 7-I)$ e $(I-I I-V 7-I) \ldots$ praticamente em todos os hinos a gente usava esses clichês... era o pau que rolava. Com o tempo, a gente começou a pensar com mais cuidado essa questão de como harmonizar as melodias. Um exemplo disso é o modo como a gente toca o hino do anjo da guarda atualmente... um pouco diferente do que era antes(...). Foi neste tempo que a gente foi pesquisar aqui e acolá... até mesmo pescar uma coisa ou outra das outras igrejas (Barquinha)... aprender um pouco com outros estilos... do chorinho, por exemplo, nós pegamos um pouco alguns clichês harmônicos, ritmos, as baixarias do violão de 7 cordas (contrapontos), inversões de acordes e por aí vai.

A partir deste relato, para poder analisar o antes e o depois do referido cântico, fui procurar nos arquivos de áudio coletados, a gravação antiga do hino que o entrevistado faz referência em sua fala. Por sorte, encontrei duas gravações do hino "Santo Anjo da Guarda", uma recente e outra mais antiga, que demonstram o modo como ocorreu a rearmonização da melodia. Segue abaixo as transcrições e um trecho da letra do referido salmo:

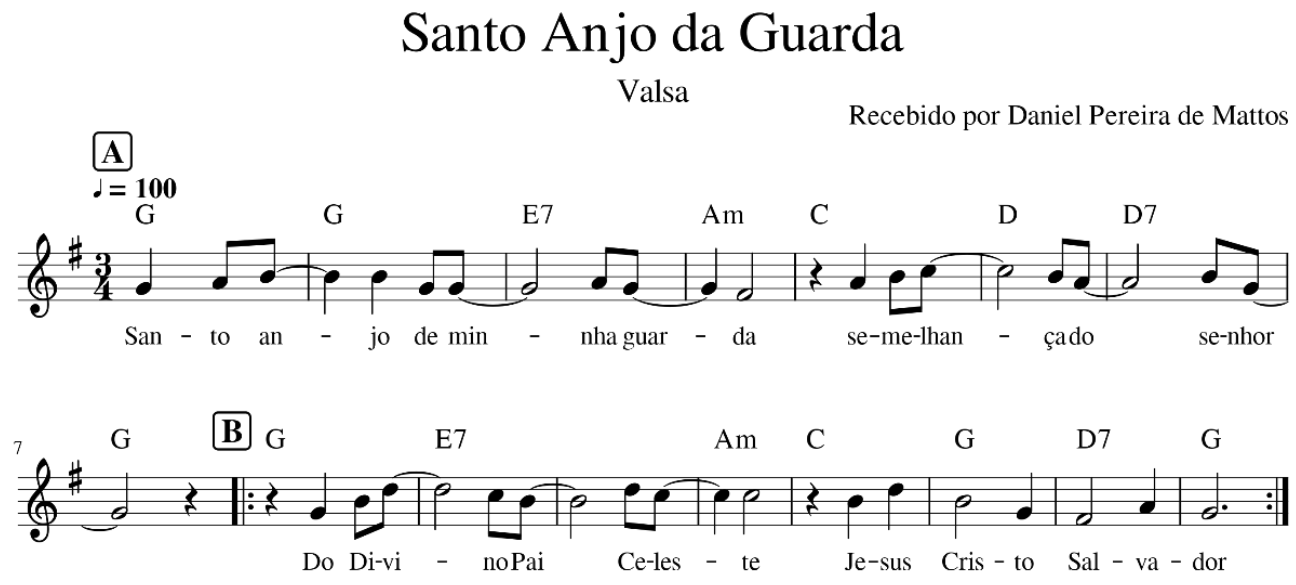

(Partitura 25) - Transcrição antiga

34 Em campo, alguns músicos relataram que já houve uma tentativa de colocar o cajon no acompanhamento musical dos hinos, entretanto, dona Chica Gabriel teria vetado a utilização desse instrumento, por ter considerado inadequado aos rituais dentro do templo. 


\section{Santo Anjo da Guarda \\ Valsa}

Recebido por Daniel Pereira de Mattos

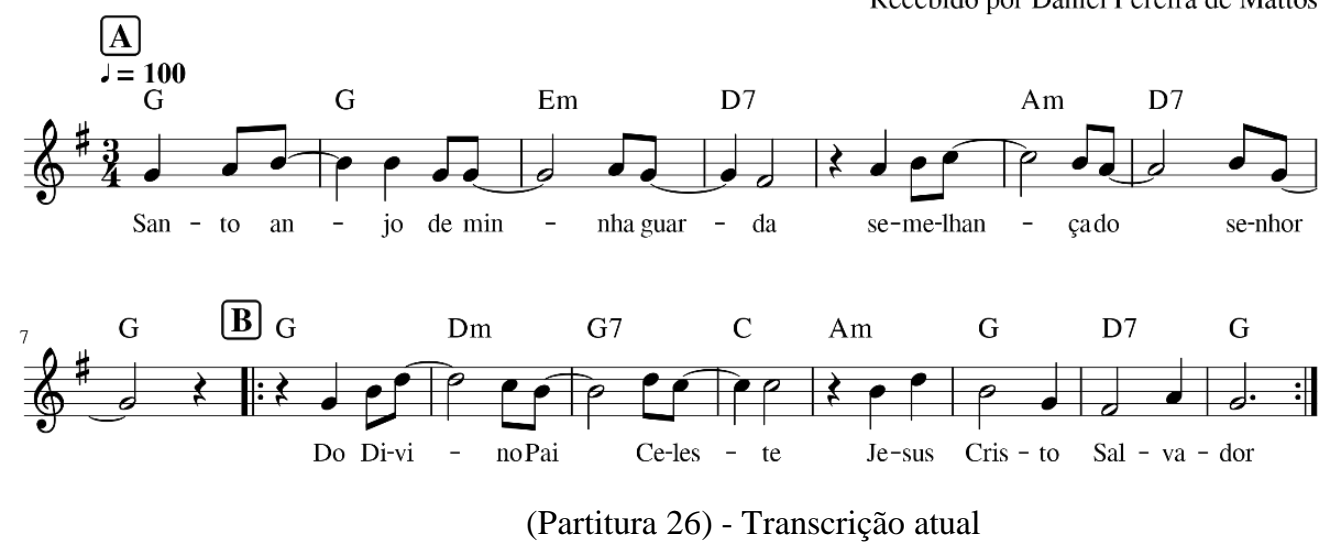

Santo anjo de minha guarda

Meu divino protetor

$\left.\begin{array}{l}\text { Do Divino Pai Celeste } \\ \text { Jesus Cristo Salvador }\end{array}\right\}$ Bis

Santo anjo de minha guarda

Suspendei meu pensamento

Para Deus lá nas alturas

$\mathrm{Na}$ luz do santo sacramento

Bis

Santo anjo de minha guarda

Vós me dê santa caridade

$\left.\begin{array}{c}\text { Guiais minha alma bem feliz } \\ \text { Desde este mundo a eternidade }\end{array}\right\}$ Bis

No bailado do CEOCPE, observa-se uma forte influência das religiões afrobrasileiras. Nas giras (como também pode ser chamado este ritual) é muito comum o canto de pontos de umbanda que se destacam ao som dos atabaques que movimentam a dança dos médiuns, em torno do salão, de modo que este evento se assemelha de muitos modos a uma gira de umbanda. Até mesmo os ritmos que são adotados nos festejos do Centro têm origem afro-brasileira (nagô, congo de ouro, samba de cabula, ijêxá e etc.). Posso afirmar que isto é um estilo marcante nos rituais festivos do CEOCPE. 


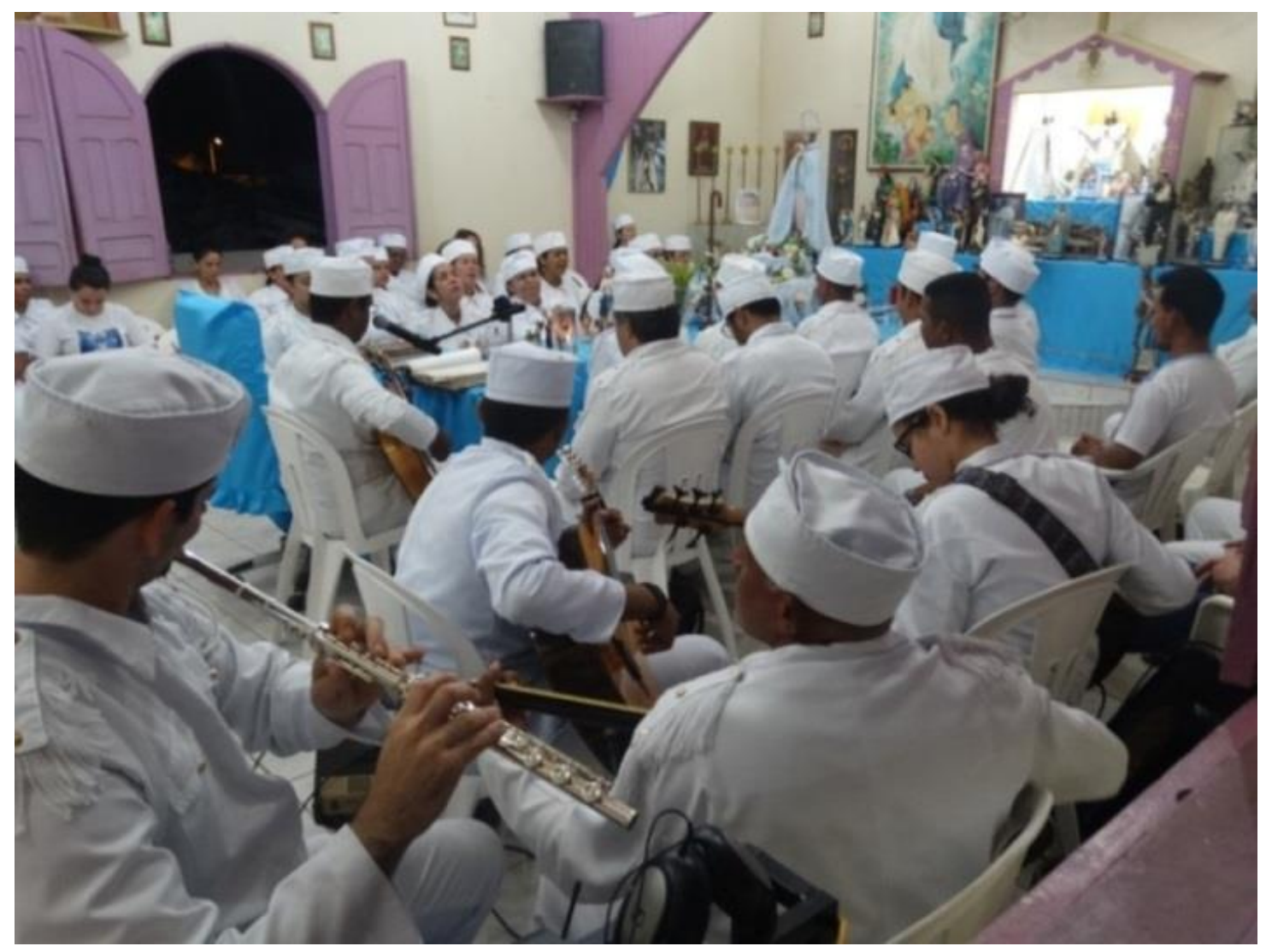

Foto 26 - Um dia de culto no interior do templo no CEOCPE ano de 2017

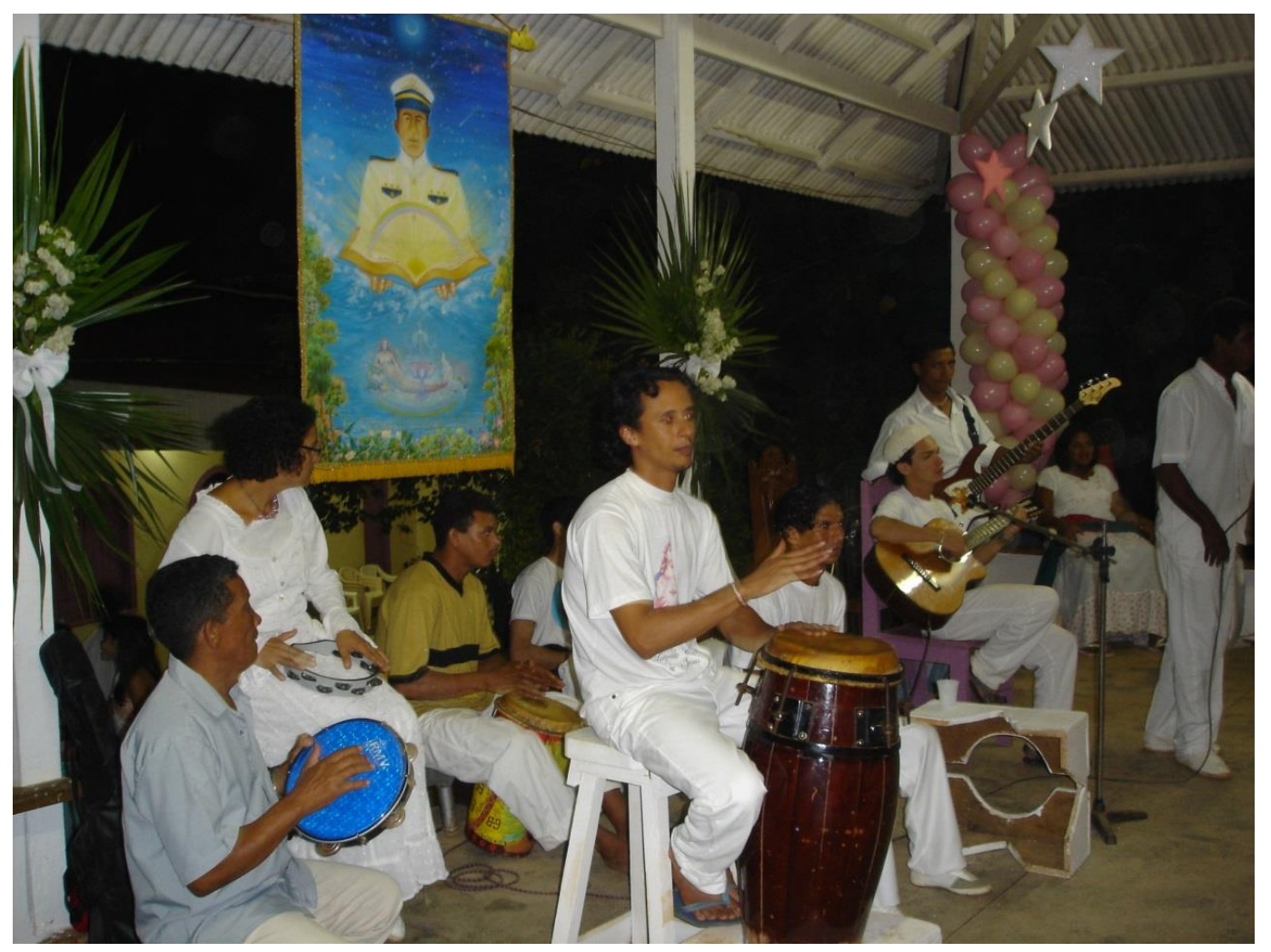

Foto 27 - Festejo de comemoração do aniversario de Dona Chica Gabriel em 07.06.2005 no CEOCPE (Acervo CEOCPE) 


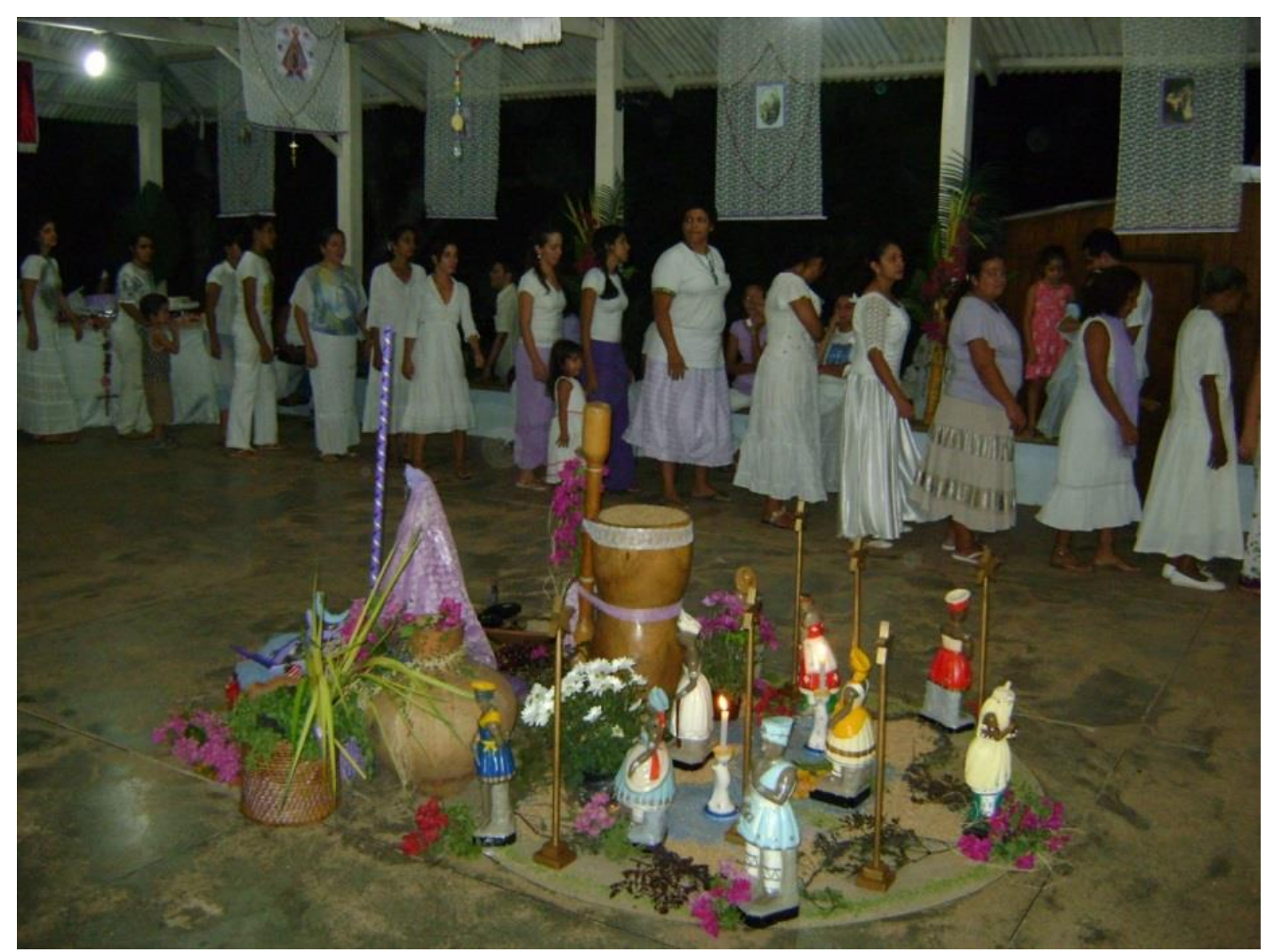

Foto 28 - Festejo de Santa Ana (Nanã) no CEOCPE em 2008. (Acervo CEOCPE) 


\section{Capítulo 4 - Música mediúnica: O “ato de receber hinos”}

Os membros da Barquinha afirmam que seus médiuns recebem espiritualmente os hinos, salmos e pontos que compõem o conjunto de cânticos que são utilizados nos rituais litúrgicos de cada Centro. Neste capítulo, me esforço para descrever este fenômeno, de acordo com a minha interpretação referente às informações coletadas. Para tanto, busquei sempre basear as entrevistas e todo o trabalho de campo seguindo os pressupostos apontados por Anthony Seeger (2004) no intuito de se realizar uma etnografia da música desta tradição religiosa.

\subsection{O ato de receber hinos: o processo de composição do repertório musical da Barquinha}

A música é uma arte que está presente em praticamente todas as civilizações humanas. Em cada cultura, ela se manifesta de um modo diferente, de acordo com características peculiares de cada agrupamento social. O processo de criação musical faz parte da cultura musical de um povo. Em sua clássica obra The study of ethnomusicology, Bruno Nettl (2005) aborda a questão do processo criativo nos mais diversos exemplos civilizatórios:

Como surge a nova música? Schubert é conhecido por ter composto uma música enquanto esperava para ser servido em um restaurante, escrevendo-a rapidamente no verso do cardápio; Mozart lançou algumas de suas serenatas e sonatas quase da noite para o dia; e Theodore Last Star, um cantor e curandeiro Blackfoot, teve visões nas quais, no espaço de um ou dois minutos, ele aprendeu com um espírito guardião uma nova canção. Mas, Brahms trabalhou durante anos em sua primeira sinfonia; Beethoven planejou e esboçou ideias para sua Nona por mais de duas décadas; (...) O grande citarista do norte da Índia senta-se diante de seu público e durante sua performance cria uma nova música no local, mas ele só pode fazer isso porque todos os dias durante horas praticou exercícios, memorizando e estabelecendo em sua mente um vocabulário musical (...), e um grupo de regras que lhe permitem, uma vez que ele tenha selecionado uma raga, o que ele deve, pode ou não pode fazer. (p.38) (Tradução minha) $)^{35}$

\footnotetext{
${ }^{35}$ How does new music come into existence? Schubert is said to have composed a song while waiting to be served at a restaurant, quickly writing it on the back of the menu; Mozart turned out some of his serenades and sonatas almost overnight; and Theodore Last Star, a Blackfoot singer and medicine man, had visions in each of which, in the space of a minute or two, he learned from a guardian spirit a new song. But Brahms labored for years on his first symphony; Beethoven planned and sketched ideas for his Ninth for over two decades; (...) The great North Indian sitarist sits down before his audience and creates a performance of new music on the spot, but he can only do this because for hours every day he practices
} 
Para Nettl, os estudiosos da música conhecem muito pouco acerca da natureza do processo de criação musical, especialmente em seu aspecto inovador. Para ele, os etnomusicólogos devem lidar com o que é novo, tanto para si próprio, quanto para o contexto geral de sua cultura. Apesar de tratar-se de algo relativo, pois aquilo que pode parecer novo aos nossos ouvidos, pode não ser para outros.

Ao invés de investigar a natureza essencial da criação musical, os etnomusicólogos normalmente examinam as maneiras pelas quais várias sociedades concebem e avaliam a criação musical. (...) Amostras de músicas ao redor do mundo podem dar exemplos de conceitos e técnicas conhecidas em diferentes sociedades. (p. 39-40) (Tradução minha) $^{36}$

Em suma, o ato de receber hinos é o meio pelo qual se dá o processo de criação do repertório musical da Barquinha. Conforme a tradição, trata-se de mensagens melodiosas recebidas espiritualmente pelos médiuns das comunidades da Missão. Grande parte destes cânticos são atribuídos a espíritos de membros da doutrina que já faleceram, incluindo o próprio Daniel Pereira de Mattos, além de entidades que compõe o panteão da Barquinha no plano espiritual (preto-velhos, caboclos, erês, missionários católicos, freis, padres, bispos, arcebispos, além de "seres encantados", por exemplo, fadas, ninfas, sereias, aves, peixes, animais em geral, e etc.). Mestre Daniel teria recebido inúmeros hinos no período em que cumpriu sua missão religiosa. Além dele, vários de seus seguidores estariam seguindo na mesma prática, recebendo espiritualmente tais mensagens. Sandra Goulart (2004) aborda bem este assunto:

De 1945 até o seu falecimento, em 1958, o Mestre Daniel recebeu cerca de duzentos hinos ou salmos, como estas músicas são mais frequentemente denominadas. De um modo geral, elas são entendidas como o resultado de um processo mediúnico, estimulado pelo consumo do Daime. Frequentemente, os integrantes da Barquinha utilizam, também, a noção de "psicografia" para explicar o ato de

exercises that he has memorized, and he maintains in his mind a musical vocabulary on which he can draw, and a group of rules that tell him, once he has selected a raga, what he must, may, or cannot do.

${ }^{36}$ Rather than probing the essential nature of musical creation, ethnomusicologists ordinarily examine the ways in which various societies conceive of and evaluate musical creation. (...) Surveys of the world's musics may give examples of concepts and techniques known in different societies. Rather than summarizing, I suggest some further ways of examining the problem. (...)

1. To some extent music is inspired, in the sense that we cannot analyze the way in which it finds its way into the thinking of a musician; (...) The concepts of inspiration, of genius, and of acquiring music directly from supernatural sources are very widespread among human societies, simple and complex. Haydn worked regular hours and depended on some kind of inspiration; when it did not come, he prayed for it (Nohl 1883:173), rather like the Native American seeking a vision who is also, in effect, praying for songs. At the other end of the line is the concept of composition as an essentially intellectual activity, in which one consciously manipulates the materials of music, organizing them carefully in ways that will make it possible for the listener to comprehend the structure, or even arranging them in ways that satisfy certain principles not audible and perceived only through careful analysis of a score. 
"receber hinos", indicando a presença da crença em seres espirituais que transmitem aos médiuns letras e melodias musicais. Nesse sentido, um hino tem sempre seu "dono", que é um ente sobrenatural específico. (p.120)

$\mathrm{Na}$ comunidade em que foi realizado a maior parte do trabalho de campo, o CEOCPE, conversei com vários médiuns que afirmaram ter recebido tais mensagens. Nas entrevistas, procurei entender melhor este fenômeno paranormal a partir do ponto de vista deles, entretanto, antes de prosseguir com esta análise, considero ser importante definir o conceito de paranormalidade. Melvyn J. Willin em seu Phd Paramusicology: An investigation of music and paranormal phenomena defendido, no Departamento de Música da Universidade de Sheffield, em fevereiro de 1999, se debruçou sobre este assunto. Para o autor, existe uma dificuldade considerável quanto à definição do termo "paranormal" e os pesquisadores têm interpretações diferentes acerca do mesmo.

C. J. Ducasse cunhou o termo para estabelecer diferenças entre questões psicológicas e parapsicológicas, mas há problemas encontrados ao se classificar os fenômenos como "normal", "anormal" ou "paranormal" (Braude, 1979). Eventos normais podem ser incomuns, na medida em que são pouco frequentes (por exemplo, eclipses), mas não são mais vistos como anormais ou paranormais, pois a ciência agora entende por que e quando acontece. Se eles ocorrerem em locais inapropriados (por exemplo, um terremoto grave no Reino Unido), pode-se alegar anormalidade, mas o evento, provavelmente, não seria descrito como paranormal, pois a ciência afirma entender a causa de tais questões. (...) Contudo relatos de aparições, comunicações espirituais, seres sobrenaturais e outros eventos fora da ciência "convencional" costumam ser considerados paranormais, se não for encontrada uma razão normal para o fenômeno. (p. 1-2) (tradução nossa) ${ }^{37}$

$\mathrm{Na}$ entrevista feita com João Batista Campos, filho de dona Chica Gabriel, também conhecido como Joca, médium do CEOCPE, ele afirmou ter recebido mais de 200 cânticos. Seguindo a linha de raciocínio exposta acima, e correlacionando-a com o presente estudo de caso, posso dizer que para este nativo trata-se de algo normal, pois sendo um evento bastante recorrente, ele tenderá a relatar e entender tais experiências

${ }^{37}$ C. J. Ducasse coined the term to differentiate between psychological and parapsychological matters, but there are problems to be encountered in classifying phenomena as 'normal', 'abnormal' or paranormal' (Braude, 1979). Normal events can be unusual in so far as they are infrequent (e.g. eclipses) but they are no longer viewed as abnormal or paranormal since science now understands why and when they happen. If they occurred at inappropriate places (e.g. a severe earthquake in the UK) abnormality might be claimed, but the event would probably not be described as paranormal since science claims to understand the cause of such matters. (...) However, reports of apparitions, spirit communications, poltergeist and other events outside of 'conventional' Science are usually claimed to be paranormal if a normal reason is not to be found for the phenomena. 
com naturalidade. Por outro lado, hipoteticamente falando, sob a perspectiva de um pesquisador com interesse de investigar o fenômeno e que carecesse de entendimento para abarcar a sua natureza e explicar empiricamente suas causas, poderíamos então qualificar tal fenômeno como paranormal. De um modo geral, a ciência "convencional" ainda é incapaz de explicar a natureza dos fatos espirituais, os quais são considerados metafísicos. Portanto, logicamente qualificar um fenômeno como normal, anormal ou paranormal dependeria também do ponto de vista de quem observa o fenômeno.

Historicamente, diferentes indivíduos, grupos e culturas produziram suas próprias definições e explicações sobre eventos supostamente paranormais, com base nos sistemas de crenças, suposições e experiências predominantes (Clarke, 1995). Por exemplo, um espírita pode muito bem aceitar uma conversa "normal" com almas que partiram, enquanto que os céticos podem descrever isso como ilusão ou como atividade paranormal. Ao contrário da maioria das crenças ocidentais, algumas culturas orientais aceitam a reencarnação, como parte do 'plano da vida' e estudos sérios estão sendo realizados nesse campo (por exemplo, Stevenson, 1975, 1977, 1980, 1983). (1999, p. 3-4) (tradução nossa) ${ }^{38}$

Willin investigou diversos fenômenos ditos paranormais na tentativa de buscar indícios que apontasse a autenticidade dos mesmos. Dentre os vários estudos de caso investigados pelo pesquisador, destaco aqui a famosa história de Rosemary Brown (1916 - 2001), médium inglesa que afirmou ter recebido mais de 400 composições musicais de autores famosos como: Lizt, Chopin, Beethoven, Schubert, J. S. Bach, Brahms, Schumman, Debussy, Grieg, Berlioz, Mozart, Rachmaninoff, dentre outros. Em sua autobiografia "Unfinished Symphonies", Brown (1971) relata que constantemente recebia a visita dos espíritos destes compositores, que ditavam para ela obras musicais compostas postumamente.

Na medida em que Rosemary começou a ganhar fama, muitos psiquiatras, musicólogos, críticos musicais entre outros pesquisadores, empreenderam uma série de pesquisas com intuito de investigar o caso. Naturalmente, este acontecimento inusitado dividiu a opinião de céticos e daqueles que acreditavam na médium. Se, por um lado, alguns especialistas disseram que as músicas analisadas certamente não seriam de autoria das celebridades, as quais mantinham contato com ela, por outro lado, outros se

38 Historically, different individuals, groups and cultures have produced their own definitions and explanations of supposedly paranormal events, based upon prevailing belief systems, assumptions and experiences (Clarke, 1995). For example, a Spiritualist might well accept as 'normal' a conversation with departed souls whereas the non-Spiritualist might describe this either as delusion or as paranormal activity. Contrary to most Western beliefs, some Eastern cultures accept reincarnation as part of 'life's plan' and serious study is being undertaken in this field (e.g. Stevenson, 1975, 1977, 1980, 1983). 
impressionaram com a sinceridade e sensibilidade de Brown, que sempre afirmou nunca ter recebido educação musical suficiente que pudesse habilitá-la a compor músicas da maneira como se deu o fenômeno.

Na conclusão de seu trabalho, Willin (1999) apresenta os seguintes resultados: em alguns dos casos investigados, descobriu-se que os mesmos eram falsos, em nenhum caso foi possível afirmar que o fenômeno seria verdadeiro; nos casos em que não havia comprovação da presença de fraude explícita, não foi possível comprovar sua falsidade.

Portanto, embora a evidência conclusiva da natureza dos fenômenos paranormais não tenha sido estabelecida, ela não pode ser totalmente descartada. Se essa tese não descobriu respostas definitivas para perguntas sobre a natureza, existência e percepção da música paranormal, ela forneceu um tratamento mais sistemático do assunto do que o anteriormente disponível e uma base para a realização de pesquisas futuras. (p. 200-201) (tradução nossa) ${ }^{39}$

O fato é que, na história da humanidade, inúmeros fenômenos paranormais são relatados em diversas regiões do planeta. De modo que sempre houve e provavelmente sempre haverá aqueles que acreditam piamente, aqueles que acreditam desconfiadamente, e finalmente os descrentes. Como foi explicado na introdução, a presente investigação se coloca como uma etnografia da música (SEEGER, 2004). Não é de meu interesse verificar a autenticidade do "ato de receber hinos", mas sim, entender melhor e descrever isto que é o processo de criação do repertório da Barquinha a partir da análise dos dados coletados em campo.

\subsection{Descrição do fenômeno à luz do método etnográfico e algumas reflexões.}

De acordo a com as informações colhidas durante a investigação, o ato de receber hinos seria, em suma, uma forma de comunicação transcendental, na qual o receptor da mensagem é um ser humano encarnado e o emissor uma fonte sobrenatural. $\mathrm{Na}$ literatura Espírita existe uma ampla abordagem que busca explicar a natureza deste tipo de fenômeno. A pesquisadora Edileide Bezerra do Nascimento (2014) explica,

\footnotetext{
39 Therefore, although conclusive evidence of the paranormal nature of the phenomena has not been established, it cannot be discounted entirely. If this thesis has not discovered definitive answers to questions regarding the nature, existence and perception of paranormal music it has nevertheless provided a more systematic treatment of the subject than was previously available, and a basis on which to conduct future research.
} 
como Allan Kardec, considerado o codificador da doutrina espírita, classifica os tipos de mediunidades por ele identificados:

No capítulo XVI do Livro dos Médiuns, Kardec apresenta um quadro sinótico dos principais gêneros de mediunidade, as diferentes variedades mediúnicas, pelas semelhanças de causas e efeitos, embora afirme que não se trata de uma classificação absoluta. E salienta que esta classificação foi trazida pelos espíritos. (...) classifica os médiuns em duas grandes categorias: médiuns de efeitos físicos: os que têm poder de provocar efeitos materiais, ou manifestações ostensivas e os médiuns de efeitos intelectuais: os que são mais aptos a receber e a transmitir comunicações inteligentes. Os médiuns de efeito intelectuais são classificados da seguinte forma:

\begin{tabular}{|c|c|}
\hline Falantes & $\begin{array}{l}\text { Os que falam sob influência dos espíritos. } \\
\text { Hoje é conhecida pelo nome de Psicofonia. }\end{array}$ \\
\hline Audientes & Os que ouvem os espíritos. \\
\hline Videntes & $\begin{array}{l}\text { São os que veem os espíritos em estado de } \\
\text { vigília. }\end{array}$ \\
\hline Inspirados & $\begin{array}{l}\text { Recebem os pensamentos sugeridos pelos } \\
\text { Espíritos, na maioria das vezes, sem o } \\
\text { saberem. }\end{array}$ \\
\hline Pressentimento & $\begin{array}{l}\text { Têm uma vaga intuição de acontecimentos } \\
\text { vulgares do futuro. }\end{array}$ \\
\hline Proféticos & $\begin{array}{l}\text { Recebem revelações de acontecimentos } \\
\text { futuros, de interesse geral, em fins } \\
\text { instrutivos. }\end{array}$ \\
\hline Sonâmbulos & $\begin{array}{l}\text { Os que, em transe sonambúlico, são } \\
\text { assistidos pelos Espíritos. }\end{array}$ \\
\hline Extáticos & $\begin{array}{l}\text { Recebem revelações dos Espíritos, em } \\
\text { estado de êxtase. }\end{array}$ \\
\hline $\begin{array}{ll}\text { Pintores } & \text { ou } \\
\text { desenhistas } & \end{array}$ & $\begin{array}{l}\text { Os que pintam ou desenham. Hoje, } \\
\text { denomina-se, mais frequentemente, de } \\
\text { Psicopictoriografia, Psico-pictoriografia, ou } \\
\text { Pintura Mediúnica. }\end{array}$ \\
\hline Musicais & $\begin{array}{l}\text { Executam, compõem ou escrevem músicas, } \\
\text { sob a influência dos Espíritos. }\end{array}$ \\
\hline Psicógrafos & Escrevem sob a influência dos Espíritos. \\
\hline
\end{tabular}

Os relatos obtidos com os membros da Barquinha apontam para o fato de que é muito rara a ocorrência de médiuns de efeito físico. Por outro lado, é frequente a 
atuação de médiuns de efeitos intelectuais. A psicofonia desponta como uma prática comum na Barquinha. As Obras de Caridade, por exemplo, é um ritual no qual os médiuns incorporam as entidades para que as pessoas possam se consultar com os espíritos em busca de conselhos, esclarecimentos, curas e etc.. ${ }^{40}$

Em campo, foi possível identificar possíveis casos de Psicopictoriografia ou Pintura Mediúnica, como no caso da pintura que a exporemos, a seguir, que, segundo os relatos obtidos, foi produzida por médiuns da casa sob a influência dos espíritos:

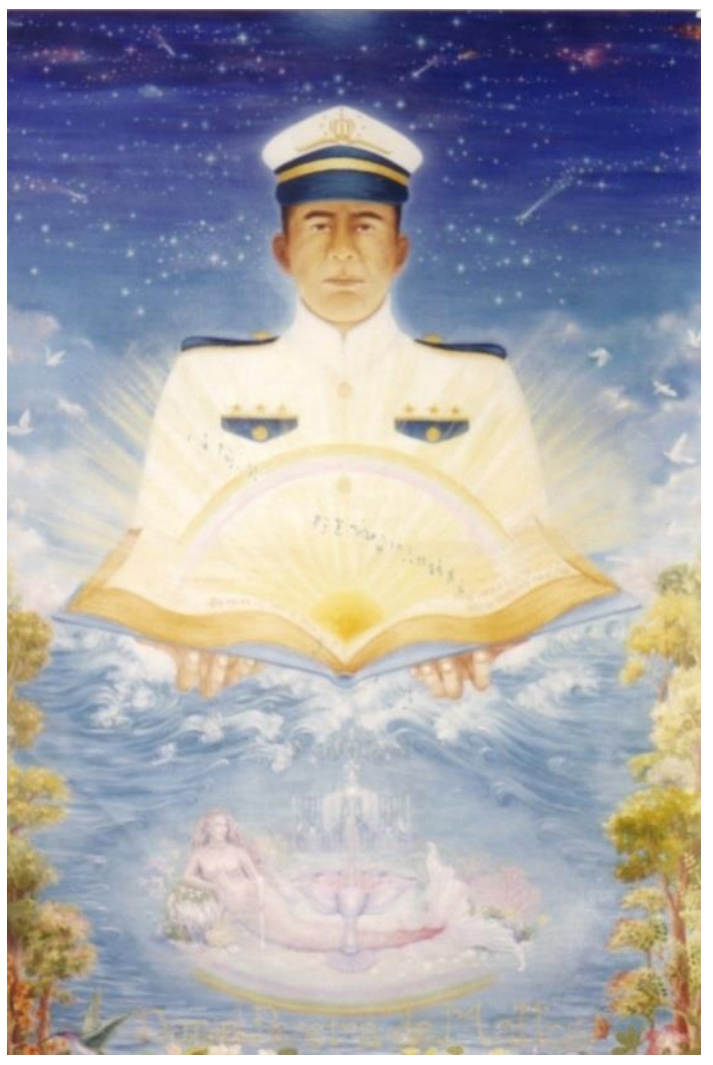

Foto 29 - Pintura de Frei Daniel e o livro azul feita por Selene Fortini, membro do CEOCPE (Acervo do CEOCPE)

Também foi relatada a ocorrência de psicografias no CEOCPE. No exemplo que colocamos, a seguir, temos uma mensagem cuja autoria é atribuída ao espírito de Daniel Pereira de Mattos, que teria sido recebida por João Batista (Joca), em novembro de 2001:

Em um dia muito lindo, andando um pouco descontraído, sentindo em meu corpo a brisa do dia, contemplei um passarinho que voava. Não muito distante dali, ele pousava. E com um cântico encantador, que chamava ainda mais a minha atenção, ele solava uma linda canção

${ }^{40}$ Este ritual foi melhor explicado no capítulo $3^{\circ}$. No CEOCPE, obtive informações indicando que, no Centro em questão, as incorporações são conscientes, ou seja, geralmente, o aparelho não perde a consciência ao incorporar um espírito. 
com um silvo muito longo, que não dava espaço nem para seu fôlego, pois a melodia que ele entoava era a mais linda que já havia escutado. Então eu pensei: se esse passarinho tem a capacidade de me encantar com o seu cântico maravilhoso, é porque existe nele o dom de Deus. Será que também não existe em mim o dom da harmonia e da sintonia? Peguei então um violino que há muito tempo me acompanhava. Me posicionei e elevei o meu pensamento a Deus. Meus dedos navegavam como se fossem plumas sobre as cordas. E o ritmo se propagava como se fosse a batida do meu coração. Percebi então que esta sincronia dava direção a uma linda canção, que nela contemplava as belezas e maravilhas do universo. Como se fosse um sonho eu viajei nas palavras que destrinchava aquela bela canção, daí pude perceber que o dom divino está exposto para todos dentro de sua Criação. E ao terminar a linda canção, percebi a alegria da natureza e de todos seus habitantes, pois, naquele momento, eu estava descobrindo a mim mesmo, e a passarada estava em festa, naquele momento, eles representavam os olhos de Deus e o dom divino estava exposto no meu ser, para a partir daquele momento, eu me preparar para receber as mensagens divinas e ensinar ao meu próximo como amar a Jesus, fazendo a caridade para aqueles que me procurassem; e dividisse o pão com aqueles que tivessem fome, por isso eu cumpri e da minha chama foi se propagando a luz do meu coração e o amor dos meus irmãos, para que essa doutrina pudesse continuar e que fosse passando de geração a geração até o dia em que fosse determinado. Por isso, meus filhos, não se abalem e façam penitência. Porque o Pai prometeu e sua palavra há de se cumprir.

$\mathrm{O}$ ato de receber hinos se encaixaria na classificação de mediunidade musical (NASCIMENTO, 2014). Observa-se que, no geral, as mensagens são versos melodiosos em que o conteúdo textual aborda desde preceitos da moral cristã, orações, súplicas, veneração a santos católicos, veneração à natureza e à criação divina como um todo, entre outros tópicos que atendem à liturgia dos rituais da Barquinha.

\subsection{Análise do fenômeno da música mediúnica na Barquinha}

Analisando o hinário do CEOCPE verifiquei que geralmente o conteúdo da mensagem é uma narrativa que possui um interlocutor. Identifiquei, pelo menos, duas modalidades distintas em torno do ato de receber hinos e que merecem uma reflexão mais aprofundada. A primeira corresponde aos casos em que um médium recebe um hino cujo interlocutor da narrativa seria ele próprio. Os exemplos que colocaremos a seguir representam os hinos que se enquadram na primeira modalidade: 


\section{Culto Santo}

Valsa

Recebido por Daniel Pereira de Mattos

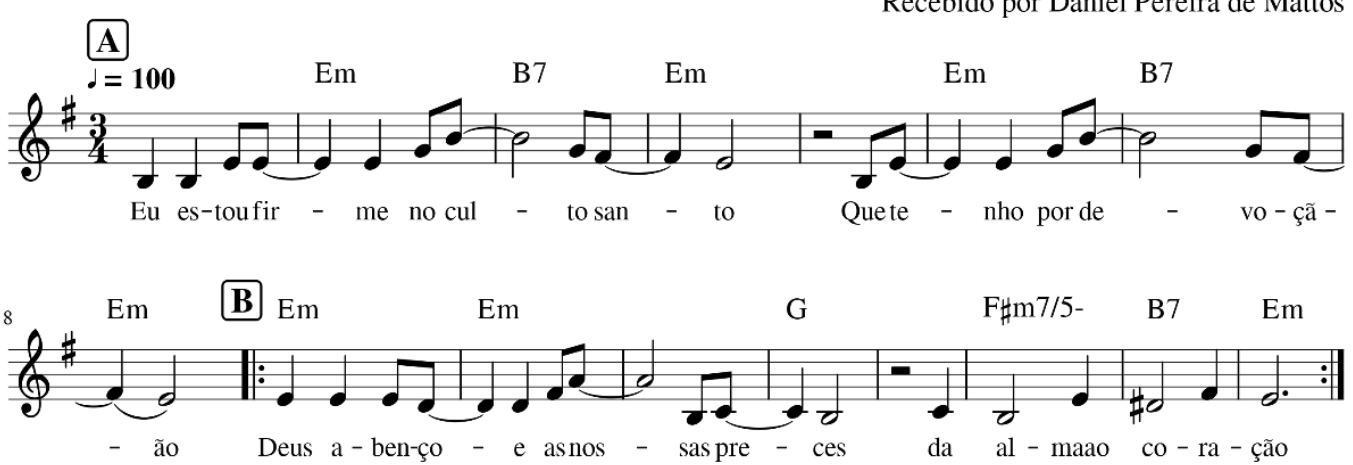

(Partitura 27)

Eu estou firme no Culto Santo

Que tenho por devoção

Deus abençoe as nossas preces

Da alma ao coração.

Bis

O divino Pai Eterno

Para nos dar a salvação

Mandou preparar os caminhos

Para Jesus, por São João.

Bis

São João preparou a doutrina

E em tudo testificou a luz

E lá no Rio de Jordão

Ele batizou Jesus

Bis

São João nos abençoe

E nos dê caminhos de luz

Seja vós o nosso guia

Para os santos pés de Jesus

Bis

Acima, um trecho do hino "Culto Santo" recebido por Mestre Daniel em vida de matéria $^{41}$. Nesse caso, ao que parece, o receptor da mensagem é também o seu interlocutor. A narrativa contém revelações sobre aspectos da fé cristã que são agregadas à doutrina, compondo assim o universo cosmológico da Barquinha. Tais textos sagrados seriam transmitidos aos médiuns sobrenaturalmente, em forma de melodias, por meio de uma espécie de inspiração. Vejamos outro exemplo no trecho do hino que segue:

${ }^{41}$ Em vida de matéria, é um termo comum, entre os membros da Barquinha, os quais entrevistei em campo, que se refere à época em que a pessoa era viva, ou seja, antes de seu falecimento. 


\section{A Preparação}

Bolero
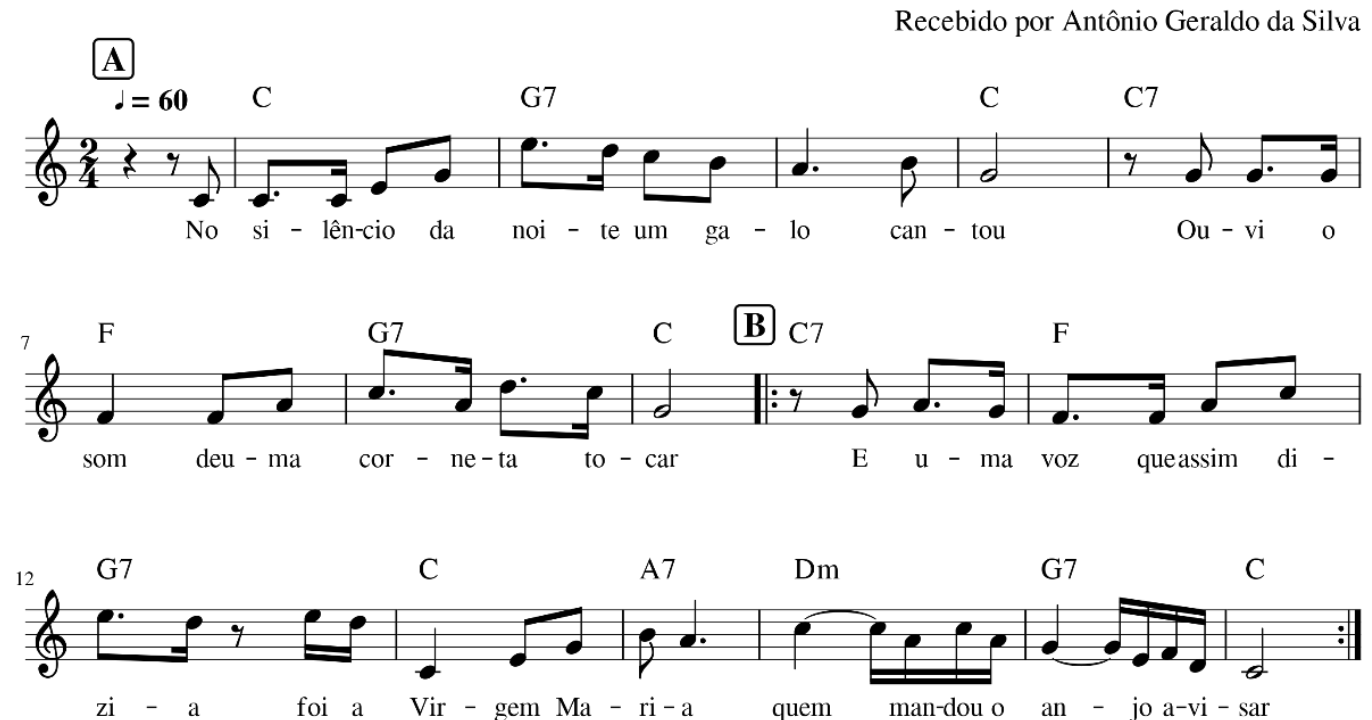

(Partitura 28)

No silêncio da noite um galo cantou

Ouvi um som de uma corneta a tocar

E uma voz assim dizia: foi a Virgem Maria

Quem mandou o anjo avisar

Bis

O galo cantou e tornou a cantar

E o santo anjo assim falou

$\left.\begin{array}{l}\text { Ele assim dizia: Está pra chegar o dia } \\ \text { Da volta do nosso Salvador. }\end{array}\right\}$ Bis

Meus irmãos amigos eu estou nesta casa

Trabalhando com esta santa luz

Limpando as matérias e preparando nossas almas

Para a volta do nosso Senhor Jesus

Bis

Meus irmãos, amigos, não querem acreditar

Na santa luz desta sessão

Mas, nesta obra eu explico, ela nos testifica

Que esta luz é o caminho da salvação.

Bis

Nesse salmo, recebido por Mestre Antônio Geraldo em vida de matéria, é possível deduzir que ele próprio está narrando a mensagem, numa espécie de relato. $\mathrm{O}$ texto estaria revelando uma experiência mística do próprio médium, que resultou nos versos melodiosos que contam detalhes da mesma.

Por outro lado, no caso da segunda modalidade identificada na análise do hinário, percebe-se uma situação na qual a entidade que "traz" um salmo seria também a 
interlocutora da narrativa. A seguir, coloco trechos de hinos que representam os cânticos que se enquadram na segunda modalidade:

\section{Mistério Sagrado}
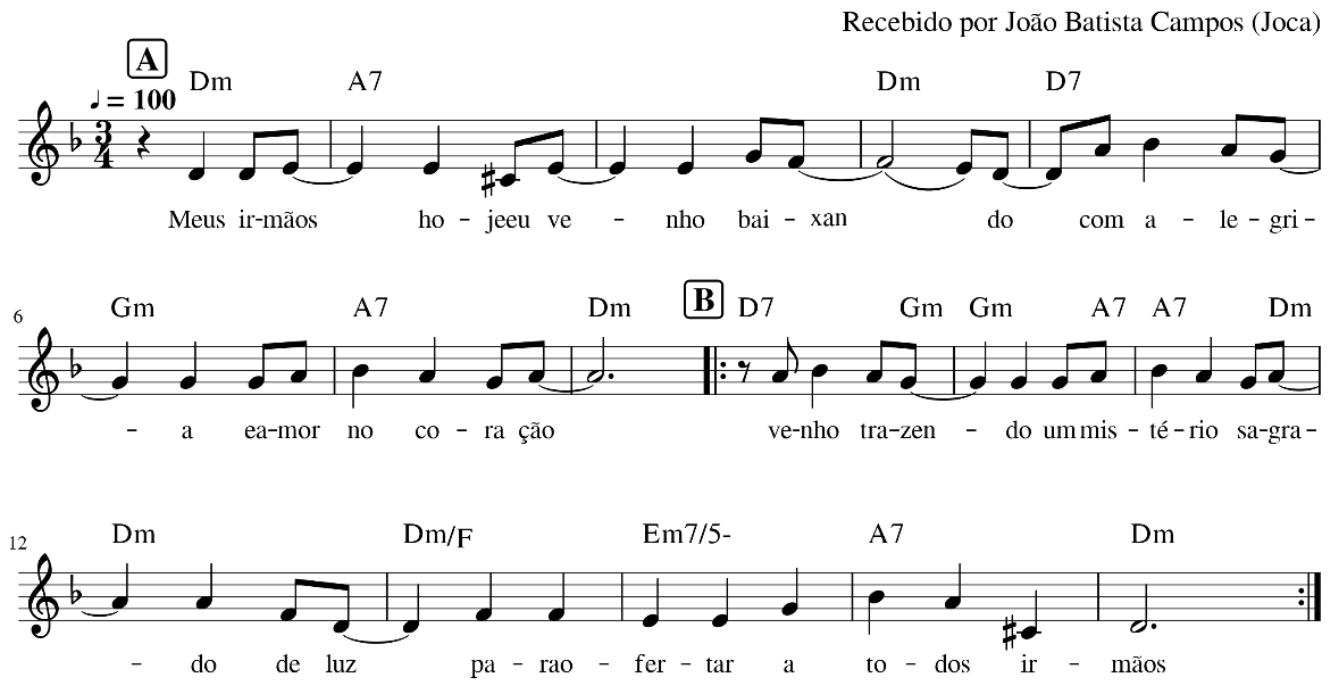

(Partitura 29)

Meus irmãos hoje eu venho baixando

Com alegria e amor no coração

Venho trazendo um mistério sagrado de luz

Para ofertar a todos irmãos

Quando vivi em vida de matéria

Ensinando a amar com o coração

Eu cantava e tocava com santa harmonia

Lindos salmos de adoração

Bis

Pois Jesus enviou os seus mensageiros

Para me entregarem na luz

Cada salmo que eu recebi, meus irmãos

Foram dádivas do amor de Jesus

Bis

Por isso vamos irmãos cantar com alegria

Lindo salmos com santa harmonia

Todos eles são lindos louvores de luz

Para Deus e a Virgem Maria

Bis

Pergunto com alegria e amor no coração

Se ficaram felizes com este bom irmão

Quem se escusa a cantar e rezar nesta luz

Se recusa a louvar a Deus Jesus

Bis 
Vou subindo na paz, amor no coração

O mistério sagrado eu deixo com os irmãos

Sou o Mestre Antônio Geraldo, irmãos

Que decanto esta linda canção

Bis

Segundos os relatos colhidos, este hino é uma mensagem de Mestre Antônio Geraldo da Silva que faleceu em 28 de julho do ano de 2000. Foi recebido pelo médium João Batista no ano de 2003. Na narrativa, o mensageiro estaria relatando fatos que remetem aos tempos em que ele viveu na Terra, "eu cantava e tocava com santa harmonia lindos salmos de adoração. " A seguir, outro exemplo que se enquadra na segunda modalidade:

\section{Ave Maria - A Luz que nos guia \\ Recebido por Aguida M.a Campos do Nascimento}
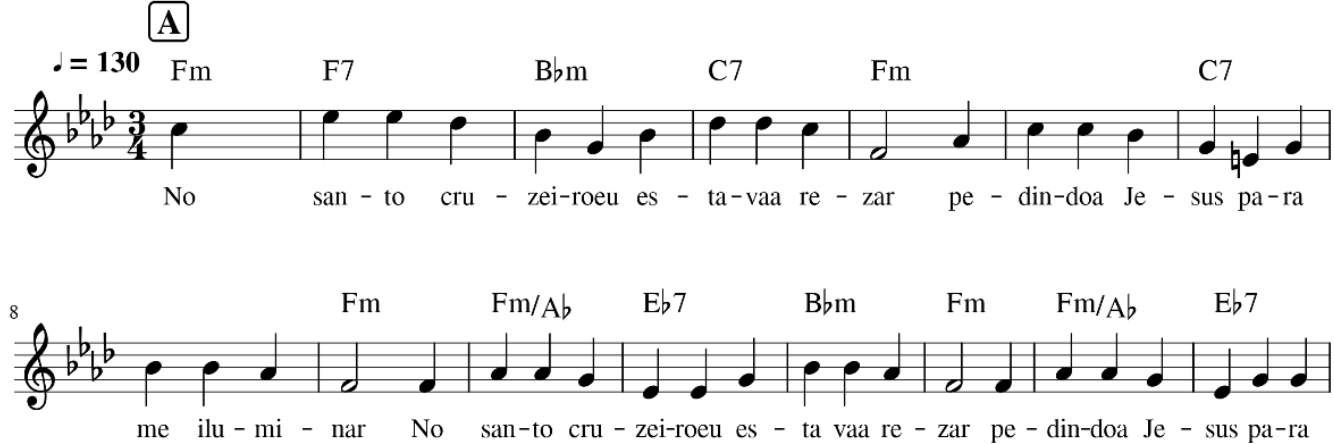

B
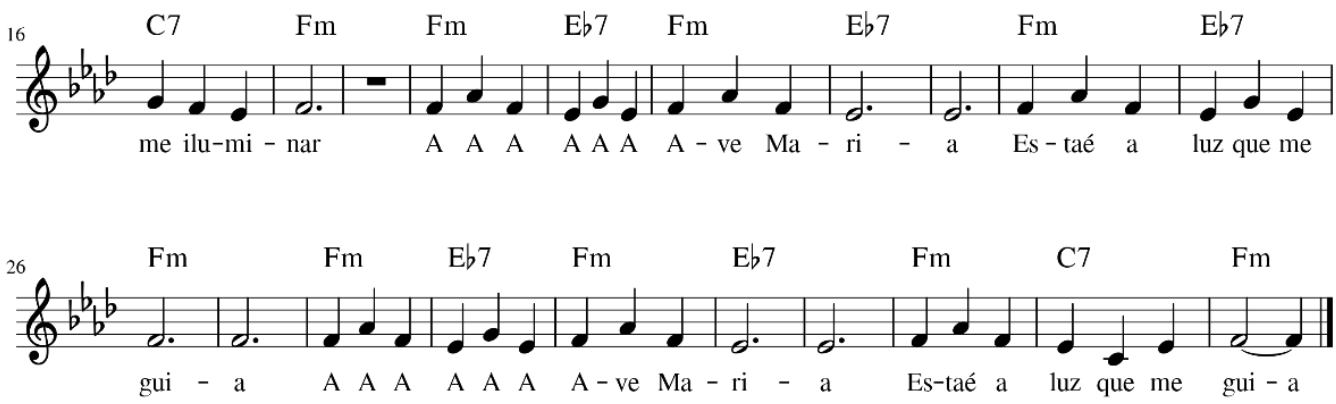

(Partitura 30)
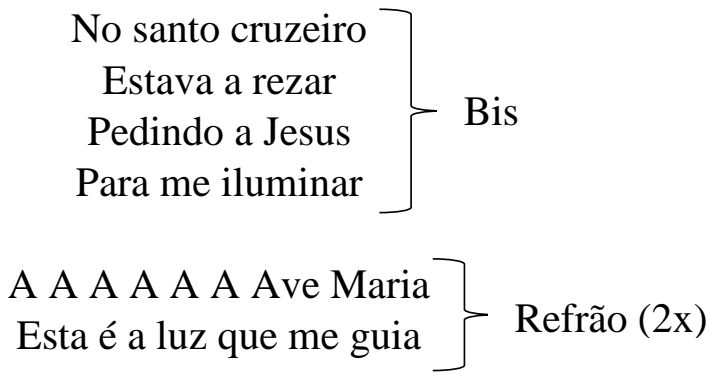


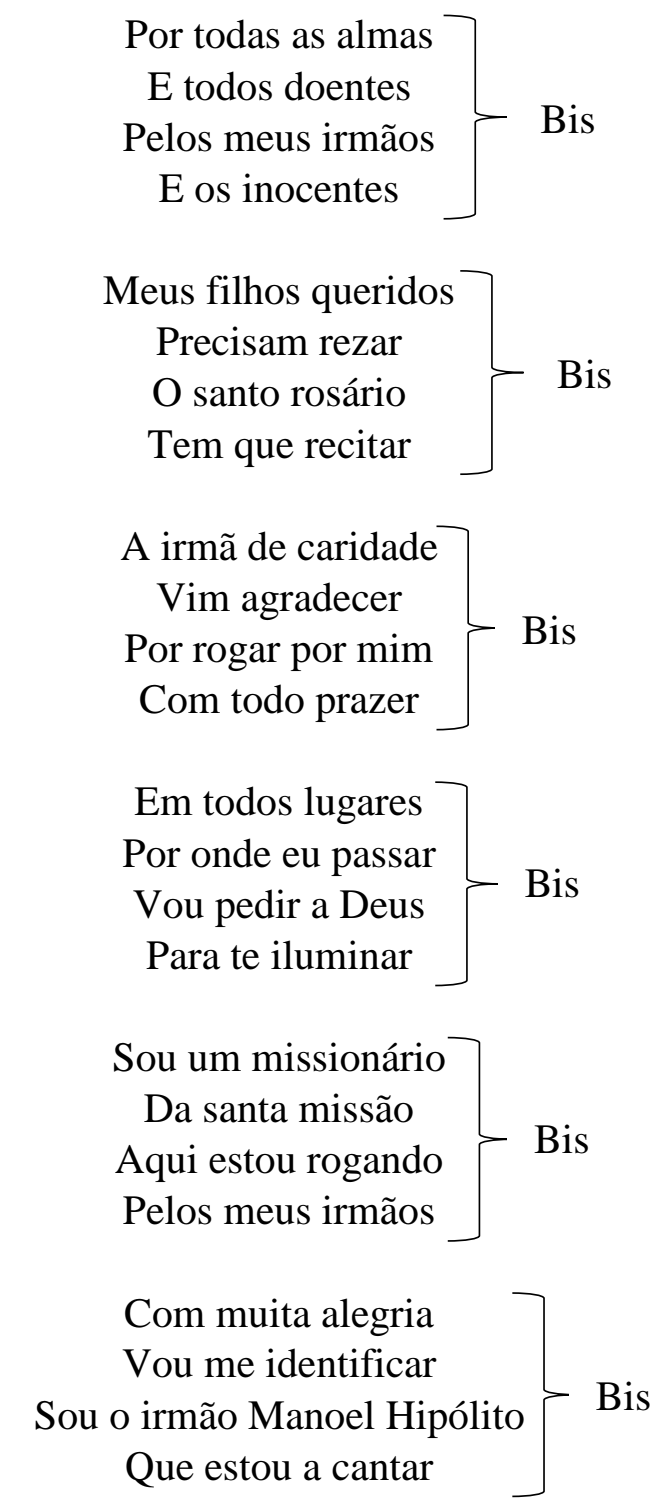

Este hino foi recebido por uma das filhas de Dona Chica Gabriel, a médium Águida Maria Campos do Nascimento do CEOCPE, em 31 de maio do ano de 2001. O mensageiro teria sido o irmão Manoel Hipólito de Araújo, que liderou o CECOCJFL desde a saída de Mestre Antônio Geraldo até o seu falecimento em 17 de agosto do ano 2000. Os fragmentos modais da melodia deste hino dão a impressão de tratar-se de um canto gregoriano. Nos dois exemplos colocados acima, o mensageiro se identifica e se constitui como o interlocutor da narrativa (segunda modalidade).

Tal como podemos depreender a partir da bibliografia consultada, o ato de receber hinos não é algo que aconteceria exclusivamente na Barquinha. Na doutrina do Santo Daime, identificamos a ocorrência de fenômeno semelhante. Rodrigo Sebastian de Moraes Abramovitz (2003) - em dissertação de mestrado em musicologia: Música e Miração: uma análise etnomusicológica dos hinos do Santo Daime - buscou identificar 
as relações entre música, miração (transe), ritual, cultura e comunidade desta tradição religiosa. O autor levanta a hipótese de que os hinários seriam "biografias musicais" de seus respectivos receptores.

"O que chamo aqui de hipótese das biografias musicais é uma tentativa de interpretar os hinos que, segundo os adeptos, são "recebidos" de entidades do "astral" como um relato da experiência do recebedor, nos rituais e na vida cotidiana. (...) Esse aspecto de expressão da experiência humana também cumpre determinadas funções, pois cria nas pessoas que ouvem, cantam e tocam os hinos uma identificação com aquela experiência. Isso, juntamente com a bebida enteógena, pode levar a revelações (insights) sobre o momento que a pessoa está vivendo, em diversos campos, como o espiritual, o psicológico e o profissional.” (p. 22)

É possível afirmar que o fenômeno musical-mediúnico que ocorre nestas duas tradições religiosas amazônicas são bem semelhantes. Em campo, analisei muitos hinos recebidos por Daniel Pereira de Mattos, Antônio Geraldo da Silva (Barquinha), além dos hinários de Mestre Irineu Serra e Sebastião Mota de Melo (Santo Daime). Percebi que, ao que tudo indica, na maioria dos hinos os médiuns estariam narrando as respectivas mensagens melodiosas $\left(1^{\mathrm{a}}\right.$ modalidade). De fato, várias das mensagens abordam temas relativos às experiências individuais de cada um deles, corroborando assim com a hipótese levantada pelo pesquisador. Entretanto, mais adiante o autor analisa um hino recebido por Mestre Irineu, no qual, em sua narrativa, existiria um provável diálogo entre o receptor (Mestre Irineu) e a entidade chamada "Flor das águas", conforme colocamos a seguir: 


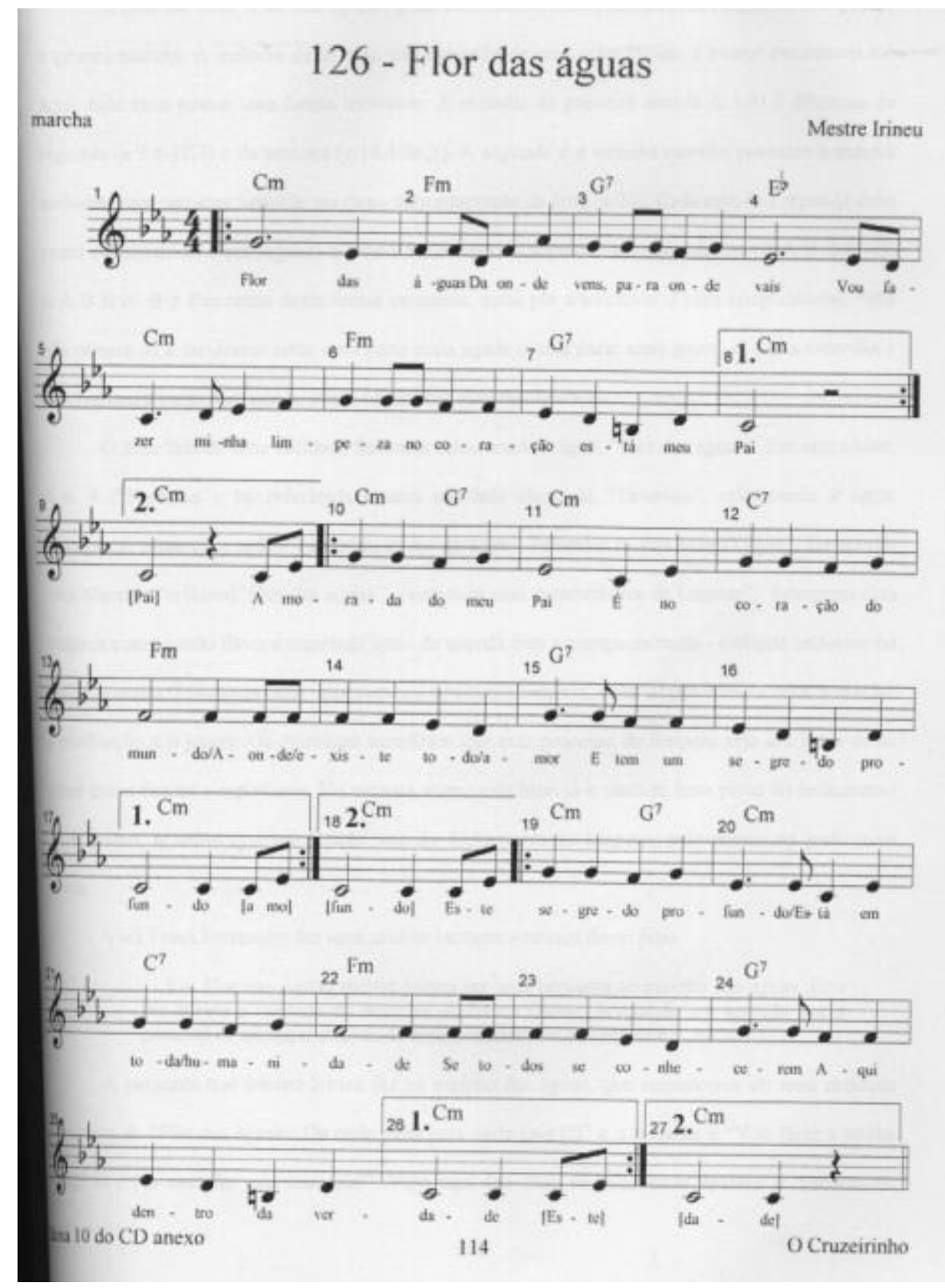

Foto 30 - Fonte: (ABRAMOVITZ, 2003)

Flor das Águas

da onde vens para onde vais

Vou fazer minha limpeza

No coração está meu pai

A morada do meu pai

É no coração do mundo

Aonde existe todo amor

E tem um segredo profundo

Este segredo profundo

Está em toda humanidade

Se todos se conhecerem

Aqui dentro da verdade 
Segundo Abramowitz (2004):

A pergunta que Mestre Irineu faz ao espírito das águas, que entendemos ser uma entidade feminina, é: "Flor das águas / Da onde vens para onde vais[?]" e a resposta é "Vou fazer minha limpeza / No coração está meu pai" Vejo aqui um caso de hino onde aparece o discurso do recebedor e o discurso da entidade da qual o hino é recebido. Acredito que essa fusão das pessoas do discurso "eu" (recebedor) e "ela" (entidade), que aparece no hino 126, pode solucionar um problema relacionado à hipótese das biografias musicais - como poderia o hino falar sobre o recebedor, sendo um recebimento de entidades do astral? Nesse hino e em outros encontra-se espaço para o discurso de ambos (do recebedor e da entidade da qual o hino é recebido) (p. $115-116)$

Na conclusão do trabalho, o autor afirma que: “A narrativa dos hinos (...) dá voz. ora ao recebedor, ora à entidade da qual ele está recebendo o hino.” (p. 167) Pare ele, este fato ajuda a esclarecer a questão relativa à hipótese que havia levantado, ao dizer que a "fusão das pessoas do discurso parece apontar uma solução para o problema de os hinos serem, a um só tempo, recebimentos de entidades do "astral" e testemunhos da trajetória pessoal do recebedor." (p. 167) Segundo meu entendimento, Abramovitz conclui que, por um lado, existem os hinos cuja mensagem expressa relatos, experiências pessoais dos próprios médiuns e, por outro lado, os cânticos cuja narrativa expõe o discurso das entidades mensageiras. Penso eu que o autor não aprofunda suficientemente as reflexões em torno do assunto, talvez, porque não fosse de seu interesse assim o fazer.

Assim como recomendo a continuidade do estudo das práticas musicais do Santo Daime, proponho que se iniciem os estudos etnomusicológicos de outras religiões ayahuasqueiras brasileiras, como a UDV e a Barquinha. Dessa forma, minhas conclusões parciais, neste estudo, poderão ser confrontadas com outras. (p. 166)

Analisando o repertório da Barquinha, é possível observar algumas situações distintas referentes aos personagens que estariam narrando os textos dos cânticos. A título de exemplo, cito os cânticos colocados mais acima: nas partituras 27 e 28, o discurso estaria dando voz à pessoa que está recebendo o hino; nas partituras 29 e 30, o narrador seria a entidade que trouxe o hino. Exponho adiante, um exemplo semelhante ao hino Flor das águas (foto 30), cuja narrativa (provavelmente) ora dá voz ao recebedor, ora à entidade mensageira. É um hino que faz parte do hinário do CECOCJFL, que encontramos na tese de Eloy dos Santos Magalhães (2013): "Balanços de luz": devoção e experiência a bordo do Barquinho Santa Cruz: 
HINO - SALMO:

1

Jesus Cristo Redentor

É o dono desta missāo

Me mandou a esse mundo

R Aconselhar os meus irmâos. $\}$ Bis

2

Eu digo nos salmos

Năo me canso de dizer

Pra seguir a Jesus Cristo

$R$ Só depende de vocé. $\}$ Bis

3

Do livro que recebi

Para cumprir esta missăo

Eu formei essa doutrina

R Para ensinar os meus irmāos. $\}_{\text {Bis }}$

4

Ele me entregou o livro

Mas eu năo quis acreditar

Ele disse vai meu filho

R Aprender a aconselhar. $\}$ Bis

5

Eu tomei a santa luz

E entrei na miraçăo

E vi todo o meu destino

$R$ Dentro desta missẩo.
DO LIVRO QUE RECEBI

Eu peguei minha caneta

E o meu amigo violăo

E cantei um lindo salmo

R Para a Virgem da Conceiçăo. $\}$ Bis

7

Eu já disse aos meus irmăos

Disse e torno a dizer

Para seguir esta doutrina

R Precisam me obedecer. $\}$ Bis

8

Quem me trouxe este salmo

Estas santas instruçōes

Foi quem fundou esta casinha

R Este Culto de Oraçāo.

9

Eu rogo a Deus Jesus

E a Virgem da Conceição

$\left.\begin{array}{c}\text { Que dê paz, saúde e luz } \\ \mathbf{R} \text { Para todos os meus irmăos. }\end{array}\right\}$ Bis

10

Salve esta santa casa

Este Culto de Oraçăo

E cubra com a cruz bendita

R OPresidente da missảo. $\}$ Bis

Prece: Pai-Nosso e Ave-Maria

Coro: 0 Deus

Foto 31 - Fonte: (MAGALHÃES, 2013)

Segundo Magalhães (2013), este hino foi recebido por Manoel Hipólito de Araújo (em vida de matéria). O mensageiro, ao que tudo indica, teria sido o Fundador da Missão, Mestre Daniel (a esta altura já desencarnado). Ao longo de todo o texto, percebe-se que a entidade que trouxe o hino é quem narra a mensagem. Na estrofe 8 , entretanto, nota-se que o recebedor (Manoel Hipólito) passa a ser o interlocutor da referida estrofe: "Quem me trouxe este salmo, estas santas instruções, foi quem fundou esta casinha, este culto de oração."

Outra situação bem interessante identificada em campo, ocorre quando o personagem que narra a mensagem não é nem o emissor nem o receptor. A seguir, 
coloco a transcrição e um trecho de um salmo recebido pelo médium João Batista (CEOCPE) que exemplifica isto:

\section{A minha viagem

\author{
Valsa
}

Recebido por João Batista Campos (Joca)

A

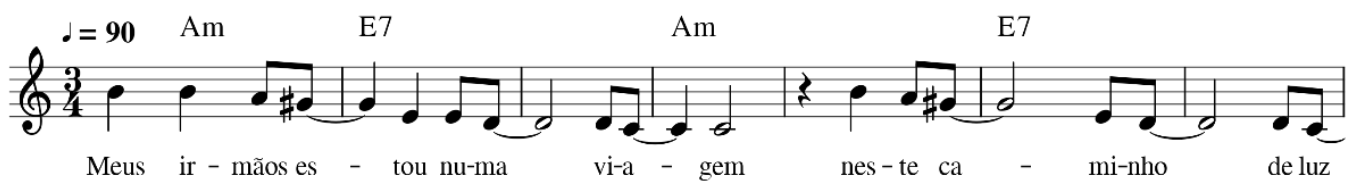

B

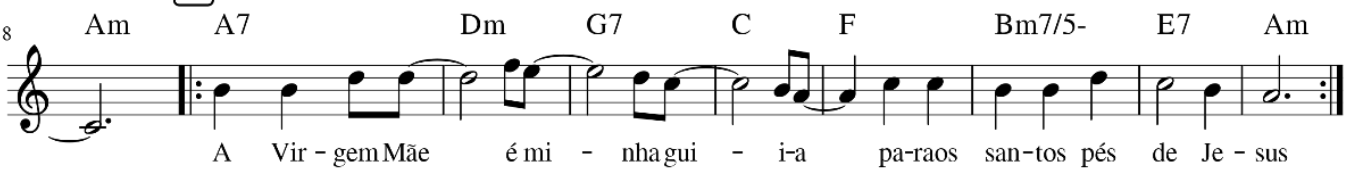

(Partitura 31)

Meus irmãos estou numa viagem

Neste caminho de luz

A Virgem Mãe é minha guia

Para os santos pés de Jesus

Eu aqui nesta casinha

Sou uma irmã de luz

Sou Irmã de Caridade

Dos exércitos de Jesus

Bis

Recebi este grande mérito

Com muito sacrifício e dor

Em muitos anos de preparo

Mas recebi com amor

Bis

Quem me deu este santo salmo

Para mim e meus irmãos

Foi Rei Jacaré-açu

Sustentáculo da missão

Bis

E pediu que eu apresentasse

Com amor no coração

Que ele deixava a firmeza

Em nossos corações

Bis

A interlocutora desta mensagem é dona Chica Gabriel (Irmã de Caridade), entretanto, quem recebeu este hino foi seu filho Joca, e a entidade que trouxe o salmo é 
o Rei Jacaré-açu que é um espírito que compõe o panteão de seres encantados desta doutrina religiosa, de acordo com as informações obtidas.

Como se pode perceber, o fenômeno musical-mediúnico que estaria ocorrendo nestas duas doutrinas ayahuasqueiras (Barquinha e Santo Daime) são bem semelhantes. Diante disto considero não estar suficientemente clara a afirmação de Abramovitz (2003) de que os hinos seriam, "a um só tempo, recebimentos de entidades do "astral" e testemunhos da trajetória pessoal do recebedor" (p.167, grifo nosso). Ao meu ver é uma situação que carece de uma abordagem mais ampla, em favor de um melhor entendimento. Na pequena amostra colocada ao longo deste capítulo, observa-se que existem situações diversas. Caso fosse efetuado o estudo de todo o conjunto dos cânticos, poderíamos ver que cada hino possui uma narrativa que deve ser analisada individualmente. Cada caso apresenta um contexto particular, um enredo com suas especificidades e seus mistérios muitas vezes imperscrutáveis.

\subsection{A questão da autoria}

Durante a investigação, algumas questões inquietaram-me. A quem devemos atribuir à autoria destes cânticos? Qual a relação entre o ato de receber hinos e inspiração? A questão é delicada, já que os membros da Barquinha afirmam que tais composições musicais seriam "recebidas" espiritualmente. Muitos relatos dizem que os compositores seriam as entidades espirituais, os ditos aparelhos apenas "escrevem" aquilo que recebem mediunicamente. Diante desta dúvida, resolvi buscar esclarecimentos sobre este assunto que me intrigou de modo particular. Além disso, precisava colocar adequadamente as informações referentes à autoria dos cânticos nas partituras transcritas ao longo de todo o texto.

Receber hinos seria então uma atividade diferente de se compor uma música por conta própria. Lucas Kastrup Fonseca Rehen (2007), aborda esse tema da seguinte maneira:

De acordo com o discurso nativo, receber um hino é absolutamente diferente de compor uma música, isso porque em uma composição, ainda que possa existir o fator da "inspiração" ou até mesmo da "intuição", o compositor é sujeito do processo de autoria, estando apto a experimentar, alterar e influenciar a música em todas as suas dimensões: rítmica, harmônica, melódica e poética; sentindo-se de alguma forma o seu proprietário, aquele que "faz", "cria" e/ou "inventa". Já para os seguidores do Santo Daime, os hinos seriam dádivas de seres sobrenaturais que as oferecem para os adeptos - neste 
caso chamados de "aparelhos" - que apenas "recebem" para então cantar em conjunto com outros membros do grupo. (p. 187)

De acordo com os relatos obtidos, é possível afirmar que os membros da Barquinha, no geral, compartilham de opinião semelhante ao discurso nativo, presente no senso comum dos seguidores do Santo Daime, quando o assunto é receber um hino. Durante a investigação, pude observar que trata-se de um assunto delicado, na medida em que existe o risco de se cair na superstição. Estes cânticos cumprem uma função estritamente litúrgica nestes rituais, de modo que o recebimento de um hino seria uma "vontade divina", uma determinação superior. Mais adiante em sua investigação, Rehen coleta depoimentos que abordam a questão da autoria dos hinos:

Os depoimentos que coletei variam bastante em relação a uma definição da identidade dos "seres", doadores originais dos hinos: Deus é citado, elementos da natureza como o sol, a lua, as estrelas, o vento, o mar, a floresta, assim como arquétipos católicos tais como Jesus Cristo, Virgem Maria, São João, São José, anjos e arcanjos e até antigos padrinhos como Sebastião Mota de Melo, o próprio Mestre Irineu ou entes queridos já falecidos - conforme apresentado em muitas letras de hinos - mas a resposta de uma das entrevistadas, que também não é única a descrever assim, ajuda a prosseguir com a minha análise: "[De quem você recebe seus hinos?] Eu imagino que seja do meu Eu Superior" (p. 192, 2007)

Vimos, no início deste capítulo, que o ato de receber hinos poderia ser considerado um evento comum (normal) (WILLIN, 2009) para alguns médiuns que constantemente estariam recebendo estas mensagens, entretanto a resposta que Lucas Kastrup obteve de um de seus entrevistados revela que a natureza em si do ato de receber hinos é um fenômeno complexo; o modo como se dá esta comunicação entre o ser humano encarnado e o espírito desencarnado, ou até mesmo a natureza que envolve um ato de inspiração divina é algo difícil de ser racionalizado.

No caso desta investigação na Barquinha, numa tentativa de se chegar a um entendimento superficial do processo que envolve o ato de receber hinos, ou seja, sem a intenção de querer entender a fundo a natureza do fenômeno paranormal, identifiquei duas modalidades que envolvem o recebimento destas comunicações transcendentais, conforme foi explicado anteriormente. A partir desta metodologia, por ora adotada aqui, percebe-se que no caso da segunda modalidade, a qual se refere aos hinos recebidos cujas entidades que "trazem" tais mensagens seriam também os interlocutores das narrativas (conforme partituras 29 e 30), ao que parece, as entidades seriam os autores das composições, os médiuns apenas "escreveriam" as mensagens ditadas pelos 
espíritos. Já no caso da primeira modalidade de recebimento, na qual os próprios médiuns que recebem os hinos seriam os interlocutores (conforme partituras 27 e 28), não fica nítido a quem atribuir-se à autoria da composição. Na entrevista com o Antônio Geraldo da Silva Filho, atual Presidente do CEDPM obtive o seguinte relato acerca deste assunto.

\begin{abstract}
Então o hino... como é que você diz? Eu recebi um hino. Você recebeu um hino? De quem? Né... a pergunta é essa, de quem? Bom, então no próprio hino ele vai se identificar... a entidade que tá trazendo para você, tá lhe dando o hino, vai se identificar né... aí sim é um hino que você recebeu né... agora, tem uns hinos que são realmente... digamos assim... inspirados né... você escreve... , mas não é que você está recebendo da entidade... receber é quando você recebeu da entidade. Como é este processo? A entidade chega, né no teu ouvido, vai ditando e você vai escrevendo, você vai transcrevendo aquilo que ele tá dizendo né, depois então vem o ritmo, vem a melodia (...) Tem uns hinos que são inspiração, por exemplo, eu não afirmo com todas as letras... os hinos do Alto Santo (Santo Daime) né... que nem você tava dizendo uns recebem, outros recebem... Hinário de Fulano, Hinário de Fulano, Hinário de Fulano. Sim, nesse caso eu concordo que o Hinário é de Fulano, porque não é uma entidade que trouxe para ele, foi inspirações né, então aquele hino é dele, não é verdade? Agora, quando você recebe um hino de uma entidade... o hino é da entidade, você só é um instrumento né, e para receber é preciso, realmente, tá dentro do figurino... e assim, você receber como um bom instrumento... e, na hora necessária, você apresentar. Então, tem a diferença do hino recebido pro hino inspirado... por inspiração... é ,dessa forma que eu entendo (...) mas, podemos afirmar que todos são recebidos (...) que nem as canções do papai, ele recebeu as canções... inspiração, né... naquela inspiração ele recebeu e compôs...
\end{abstract}

Em campo, observei que nos primórdios da Barquinha, prevaleceu a primeira modalidade. Isto foi verificado quando da análise os hinos antigos, recebidos por Mestre Daniel e Mestre Antônio Geraldo. Provavelmente, uma das causas desta tendência seria o fato dos citados nomes terem sido os líderes de suas comunidades, tendo, portanto, autonomia e autoridade para serem os interlocutores das mensagens direcionadas aos fiéis por meio dos hinos. Por outro lado, observei que no CEOCPE está prevalecendo a segunda modalidade. Além de Dona Chica Gabriel, vários de seus filhos, entre outros membros do grupo, estariam recebendo hinos que se enquadram na segunda modalidade. É uma tendência recente no contexto da Barquinha. Uma provável causa disto seria a excessiva quantidade de médiuns que se estabeleceu no CEOCPE. De acordo com a pesquisa, Dona Chica Gabriel, em razão de sua intensa atividade como médium, ao fundar sua própria comunidade, promoveu ali um celeiro de membros com 
a mesma capacidade e com grande frequência de devotos interessados em aperfeiçoar suas qualidades mediúnicas. ${ }^{42}$

Entretanto, ao analisar os hinos de Dona Chica Gabriel, percebi que a mesma possui hinos, tanto na primeira, quanto na segunda modalidade. Coloco a seguir trechos e partituras de transcrições de hinos recebidos por ela.

\section{Galardão}

\section{Foxtrot}

Recebido por Francisca Campos do Nascimento (Chica Gabriel)

A

B
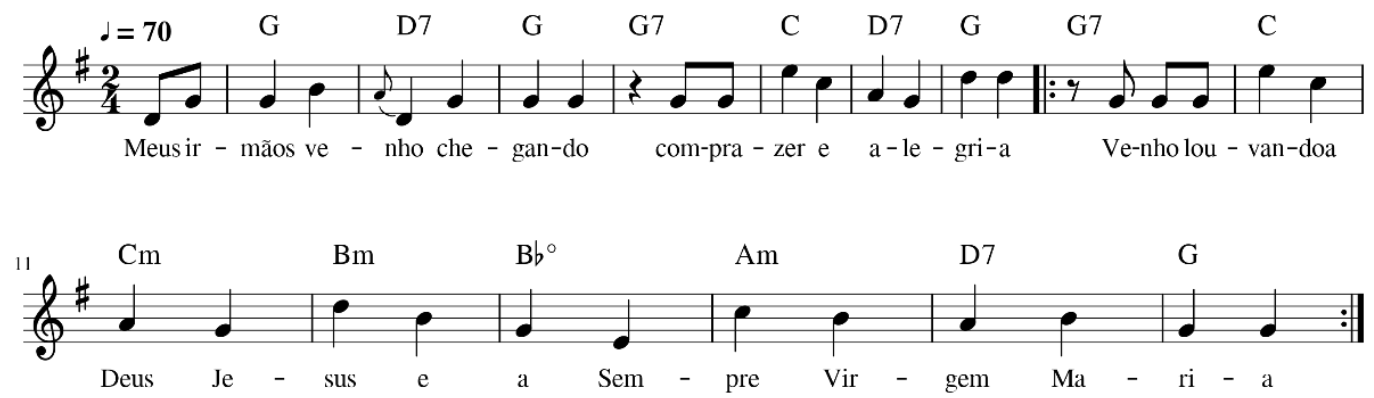

(Partitura 32)

Meus irmãos venho chegando

Com prazer e alegria

Venho louvando a Deus Jesus

E a sempre Virgem Maria

Todos que aqui seguirem

Nesta casinha de luz

Todos recebem o perdão

Para viver com Jesus

Bis

Eu sou o vosso irmão amigo

Sou o vosso professor na luz

Sou o fundador desta doutrina

Com ordem de Deus Jesus

A doutrina que recebi

Está nos mistérios desta luz

É uma dádiva sagrada

Dos mistérios de Jesus $\}$ Bis

${ }^{42}$ Em geral, no CEOCPE os médiuns da casa não recebem uma preparação específica para se tornarem "aptos" para receberem os hinos. Entretanto, pode-se considerar que este "preparo" está implícito nas orientações gerais que todos os membros recebem por meio dos ensinamentos que chegam durantes os rituais com o daime. 
Eu entreguei aos meus irmãos

Com alegria em meu coração

Para os meus irmãos zelarem

E cumprir a nossa missão

Bis

Este hino, recebido por Dona Chica Gabriel, se enquadra na segunda modalidade. A entidade que teria trazido o hino foi o Fundador (Mestre Daniel). Na narrativa, percebe-se claramente que é ele o interlocutor do texto do hino. Fato este confirmado por ela em entrevista concedida em campo. Neste caso, pode-se dizer que Mestre Daniel é quem "assina" a composição. Dona Chica Gabriel teria apenas "escrito" a mensagem melódica que, de algum modo (natureza do fenômeno), o espírito de Daniel Pereira de Mattos transmitiu a ela.

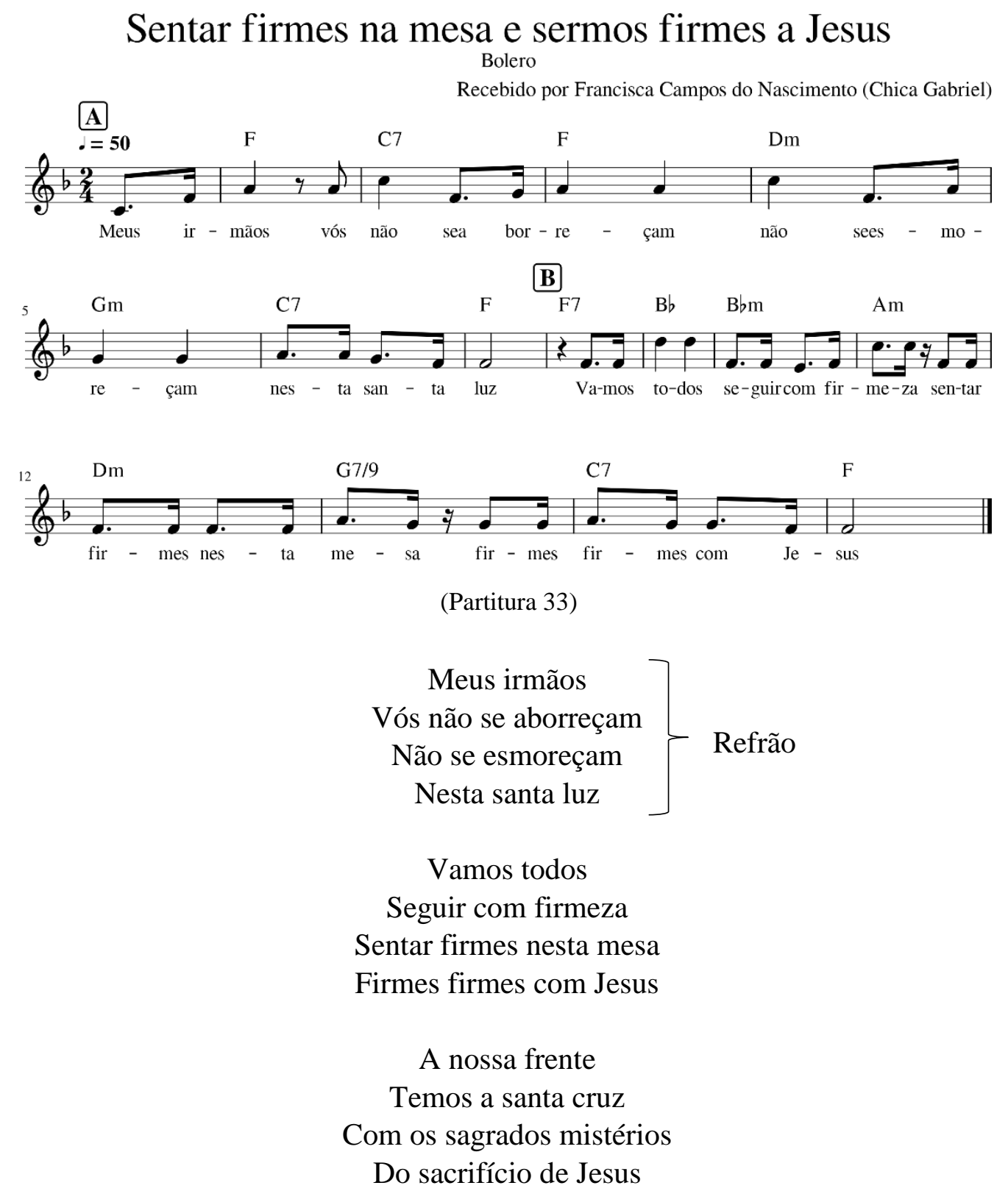




\section{Vamos agradecer a ele}

Como filhos dele

Que também somos gratos

Pelo o que ele sofreu por nós

Este hino se enquadra na primeira modalidade. É um salmo recebido por Dona Chica Gabriel, cujo texto é narrado pela própria médium, conforme a mesma relatoume. Contudo, nestes casos percebi que dentro das performances musicais dos rituais religiosos de cada Centro da Barquinha, tais narrativas tendem a criar uma situação na qual o interlocutor passaria a ser a liderança do culto, o "Presidente da Sessão".

Por fim, nos hinos da primeira modalidade, não fica claro quem é o autor da composição musical. Dona Chica Gabriel afirma que "recebeu espiritualmente" as palavras e a melodia. O seu relato aponta para a existência de um fenômeno mediúnico, uma espécie de inspiração. Como foi dito anteriormente, entender a natureza deste fenômeno não é o objetivo desta pesquisa musicológica. Deixo esta tarefa a quem queira se interessar pelo assunto. O objetivo aqui é descrever o fenômeno de acordo com os dados colhidos em campo (SEEGER, 2004).

Durante a entrevista, Dona Chica Gabriel contou-me algumas experiências relacionadas ao modo como recebeu alguns hinos. Em seu relato a médium diz que os textos das mensagens vêm às vezes em forma de intuições, outras vezes, torna-se possível até mesmo escutar uma voz que cantarola o hino a ser anotado. Em outros casos, disse que recebeu alguns hinos dentro de trabalhos espirituais com o daime. Outras vezes, por meio de sonhos. Relatou-me também que frequentemente as entidades as quais "incorpora" entoam cânticos desconhecidos, os quais ela não chega nem a registrar (escrever no papel).

Indagado sobre a quem deveríamos atribuir à autoria dos hinos que são recebidos na Barquinha, João Batista (CEOCPE) revelou um ponto de vista interessante que coloco aqui nas reflexões em torno do tema:

Vou explicar o que eu ouvi da boca da minha mãe: cada hino que se recebe... ele tem um guardião e um dono, um mensageiro que traz, independente que ele se identifique, ou não. Entendeu? Então, esses que ele não se identifica né... e é o caso do "Culto Santo" é um hino que ele (Mestre Daniel) recebeu de um ser superior do astral... não se identificou, mas como ela mesmo... explicou, todo hino tem um mensageiro, um guardião.

O entrevistado se refere ao hino "Culto Santo" (Partitura 27) para explicar que em seu entendimento, os hinos que se enquadram na primeira modalidade também 
seriam provenientes de entidades espirituais, da mesma forma que os hinos que se encaixam no caso da segunda modalidade. Logo em seguida, o médium complementa sua resposta dizendo que, independentemente disso, a mensagem:

(...) deve ser atribuída à pessoa que recebeu, entendeu? Não é... porque foi uma entidade que já se encontra no plano espiritual que trouxe, tipo Frei Daniel né... a gente que toma daime, entende... mas, as pessoas que não tomam daime, muitas vezes não compreende né... mas... os hinos que a Fátima ${ }^{43}$ recebeu né, esses daí tem que ser atribuído... à biografia dela... os hinos que ela recebeu. Que é pra depois também não acontecer, aí né... essa dificuldade que você tá tendo aí, de identificar, de saber de quem são os hinos... porque, quando foi digitado, lá no passado, não foi colocado o nome de quem recebe e isso aí traz um... como se diz assim... se perde... no caminhar das coisas ao longo da história, se perde muita coisa entendeu, por conta disso, por não saber da onde é que surgiu, quem foi que recebeu, entendeu? Tem tantas mensagens bonitas aí que a gente olha assim e nem sabe... foi Mestre Daniel ou foi o Mestre Antônio Geraldo, foi Manoel Araújo... foi... a Madrinha Chica... tá entendendo?! É esse tipo de coisa eu acho que tem ser especificado, o nome da pessoa que recebeu, data, tudo, tudo isso é importante, independente de que seja uma entidade que traga ou não... porque, você pode muito bem especificar: trago pela a entidade tal... mas, foi recebido por fulano de tal né..., mas é isso!

Na sua fala, João Batista faz referência à dificuldade que tive, por ocasião da análise do conjunto dos cânticos do CEOCPE, em identificar os médiuns que haviam recebidos alguns "hinos antigos". Joca coloca uma questão muito importante que merece uma reflexão mais aprofundada. Por mais que os membros da Barquinha comunguem de uma fé que aponta para o fato de que as entidades espirituais sejam os "donos" dos cânticos que compõem o repertório da Barquinha, para ele, a autoria de um hino recebido deve ser atribuída também ao médium que recebeu a mensagem. A questão levantada por ele evidencia um problema prático em torno do assunto. Como os Centros da Barquinha estão administrando a questão dos direitos autorais referentes aos cânticos recebidos na Casa? Diante disto, partimos em busca de informações relativas à questão.

\footnotetext{
${ }^{43}$ Fátima é uma médium do CEOCPE que já recebeu vários hinos.
} 


\subsection{Reflexões sobre proteção da propriedade intelectual da obra musical da Barquinha}

Procurei na bibliografia consultada informações que me ajudassem a compreender melhor o assunto em questão. No artigo "Propriedade Intelectual $e$ Música de Tradição Oral" Carlos Sandroni (2007) discute um assunto que muito tem a ver com o tema abordado aqui. Para o autor, existem grupos sociais que possuem uma cultura musical que, geralmente, podem ser classificadas como música folclórica ou música de tradição oral, de modo que, em alguns casos, o repertório que estas comunidades constroem ao longo dos anos termina por ser considerado como "domínio público". Segundo o autor, atualmente a esfera legal que abrange a questão dos direitos autorais não se mostra eficiente quando o assunto é proteger estes patrimônios musicais pertencentes aos grupos em questão.

Um primeiro questionamento que se poderia fazer a essa ideia de "domínio público", é sugerido pela antropóloga Sally Price, no livro Arte Primitiva em Centros Civilizados (Price, 2000:146 e seguintes). Ela levanta uma questão a meu ver muito pertinente: será que expressões do chamado "domínio público" não têm, às vezes, autor? Será que às vezes não atribuímos ao domínio público certas expressões musicais ou outras, pela simples razão de ignorarmos seus autores, e de sermos guiados nesta atribuição pelo senso comum, segundo o qual certas características culturais implicariam necessariamente em ausência de autoria?

Talvez nós não tenhamos nos preocupado o suficiente em saber o que as próprias pessoas responsáveis por tais expressões culturais sabem sobre autoria. Elas muitas vezes sabem que determinadas canções, determinados artefatos ou contos, tiveram origem em determinados indivíduos em particular (p. 2)

O autor cita várias situações que revelam o quanto alguns grupos sociais, que possuem um patrimônio cultural musical, estão vulneráveis às ações de pessoas que por ventura queiram se apropriar de suas canções ou até mesmo do seu modo de fazer música. Dentre estes exemplos, um se assemelha ao contexto da Barquinha. É o caso dos toantes Pankararu. Trata-se, de uma comunidade indígena situada na região de Tacaratu (PE) que cantam certas canções que chamam de "toantes" e que são relacionadas com certas divindades chamadas de "encantados" (2007, p. 6). Carlos Sandroni levanta o seguinte questionamento:

Alguns destes toantes foram gravados pela famosa Missão de Pesquisas Folclóricas de 1938, e mais recentemente também foram gravados e publicados pelo Núcleo de Etnomusicologia da UFPE, que coordeno, no CD livro Responde a roda outra vez - música tradicional 
de PE e da PB no trajeto da Missão de 1938 (Sandroni 2004). Ora, os toantes Pankararu, assim como as toadas dos orixás afro-brasileiros, pertencem a entidades espirituais e não a autores humanos. Pela lei brasileira, portanto, estes toantes são de domínio público; ou seja, se alguém por exemplo ouvir a gravação que nós disponibilizamos nesse $\mathrm{CD}$ e dela fizer um hit, e ganhar dinheiro com isso - hipótese pouquíssimo provável, mas não impossível (...) legalmente não é possível penalizar essa pessoa ou obrigá-la a pelo menos compartilhar estes ganhos.

O autor cita um caso particular na música Pankararu. É o toante do Mestre Guia, o encantado mais importante para este povo. Este cântico tem um significado todo especial e só pode ser cantado num evento específico do calendário ritualístico desta tradição cultural. Sandroni (2007) faz uma reflexão em torno de um fato hipotético passível de acontecer no contexto em questão:

Este toante não apenas não pode ser gravado, como não pode nem mesmo ser cantado fora da noite de domingo para segunda-feira que encerra a Festa do Umbu. No entanto, pela legislação atual o toante do Mestre-Guia seria considerado como de domínio público: se alguém chegasse lá e, sem ninguém ver, o gravasse, a comunidade não estaria protegida legalmente contra tal abuso.

Digo mais: se este toante fosse gravado, e alguém ganhasse dinheiro com ele, o caso não seria, na minha opinião, de recompensar a comunidade Pankararu com direitos autorais, porque a questão para eles nesse caso não seriam direitos autorais, mas de danos morais. Mesmo que um suposto CD com o toante do Mestre-Guia não desse nenhum dinheiro, os responsáveis por ele deveriam ressarcir a comunidade Pankararu por danos morais, pelo simples fato de tê-lo produzido, o que constituiria uma afronta à religião e à cultura Pankararu. (p. 7)

O caso citado pelo autor revela com precisão o delicado contexto que envolve algumas destas tradições de cultura oral. Hoje em dia, qualquer pessoa pode fazer gravações com extrema facilidade portando apenas um smartphone, por exemplo. Além disso, um hábito muito comum nos dias de hoje é o compartilhamento de informações, através das redes sociais, na internet. Diante do caso da comunidade Pankararu, (e aqui incluo o caso da Barquinha pela semelhança entre os contextos), o autor vai dizer que existe uma necessidade de se pensar em formas alternativas de proteção a estes repertórios. Algo diferente do que se tem hoje em torno da legislação referente aos direitos autorais.

O que seria talvez mais eficaz para proteger neste caso, não seria uma legislação, mesmo alterada, de direitos autorais, mas sim um tipo de legislação de proteção que não incide sobre, que não tem nenhuma relação com, direitos autorais. Em outras palavras, talvez precisemos abrir o leque de possibilidades de proteção legal à propriedade intelectual. (p. 8) 
Mais adiante, o autor cita um mecanismo legal que possui, em sua razão de ser, uma maneira mais eficiente para proteger estes patrimônios culturais musicais abordados aqui. É o Registro de Bens Culturais de Natureza Imaterial, instituído em 4 de agosto do ano de 2000 por meio do Decreto $\mathrm{n}^{\circ}$ 3.551. Tal registro é um instrumento legal de preservação e reconhecimento de bens culturais. Para Sandroni (2007)

(...) o registro patrimonial é uma opção a mais, alheia às armadilhas do direito autoral tradicional, para o reconhecimento e a defesa de propriedades intelectuais de comunidades tradicionais.

Finalmente, acho que não cabe esquecer que a própria legislação de direito autoral tal como existe hoje em dia, também pode ser, em alguns casos, invocada na proteção de repertórios culturais populares. Mesmo que tais repertórios não tenham na sua base nenhuma relação, e sejam até incompatíveis com a lógica do direito autoral (...) (p. 12)

Em campo, conversando com os entrevistados, busquei saber até que ponto existe, entre os Centros da Barquinha, uma preocupação quando o assunto é a proteção do conjunto de cânticos de cada Centro. Entrevistamos Flávia Burlamaqui, Diretora Cultural do CEOCPE e Coordenadora Técnica do Memorial da Madrinha Francisca. O memorial fica situado nas dependências do CEOCPE e abriga documentos, manuscritos e datilografados por Mestre Daniel, Dona Chica Gabriel, entre outros membros da Missão. Flávia me relatou os esforços que a equipe técnica vem empregando, ao longo dos anos, para organizar o acervo musical do CEOCPE. Até o momento, porém, a comunidade não tomou nenhuma medida (legal) para resguardar os direitos autorais do conjunto dos cânticos da Casa, tanto no que se refere aos hinos que foram recebidos no CEOCPE, desde a sua fundação (1991), quanto aos "hinos antigos" que, como foi visto anteriormente, foram recebidos na primeira comunidade no período anterior às dissidências que ocorreram no passado.

Por meio da bibliografia consultada, obtive informações de que o CECOCJFL inaugurou em 08 de setembro de 1995 a "Casa de Memória Daniel Pereira de Mattos" com a finalidade de:

Recolher, abrigar, preservar e disponibilizar para visitas e pesquisas os documentos e objetos de valor histórico, provenientes da administração do Centro, bem como de pesquisas feitas sobre a vida do Mestre Daniel e a missão que ele deixou. (MARGARIDO, S. \& ARAÚJO NETO, F., 2005, p. 14)

Tentei entrevistar o representante do CECOCJFL, Francisco Hipólito de Araújo Neto, mas não obtive sucesso. O mesmo disse que não estava disposto a contribuir com 
esta pesquisa. ${ }^{44}$ Também, não foi possível consultar documentos, os manuscritos originais de Mestre Daniel e gravações de áudio do acervo do referido Centro, apesar de meus esforços. Por terceiros, obtive informações de que o Centro teria tomado algumas providências no que se refere a resguardar os direitos autorais do hinário da Casa, infelizmente, porém, até o momento não consegui esclarecer se de fato alguma coisa foi realizada neste sentido, e de que forma isto, por ventura, teria sido feito.

Antônio Geraldo da Silva Filho, em entrevista, forneceu-me uma série de pistas que retratam uma faceta do quadro atual no que se refere à questão do problema da proteção do patrimônio musical da Barquinha. Perguntado sobre como o CEDPM estaria lidando com esta questão, o entrevistado emitiu o seguinte relato:

Veja bem... alguns irmãos já me falaram, por que o senhor não patenteia o hinário? Eu até já quis tentar, mas depois eu recebi a orientação de que não vale a pena, mesmo porque tudo pertence a Deus. Então, tudo que é bom tem que se espalhar... claro, de forma responsável. Então, hoje, por exemplo, eu posso chegar muito bem na tua comunidade... vocês estão cantando o hino e vocês não permitem gravar... lá na nossa também, mas neguinho bota aqui um celular no bolso, tu vai empatar? Tu vai saber pelo menos que ele tá gravando? Então, quer dizer... então nós resolvemos... eu não vou tá perdendo tempo tendo aborrecimento com tanta burocracia que tem, né, pra... não, esse hino aqui é meu. Não posso chegar lá e quebrar o gravador do cara, o aparelho do cara, porque ele está escutando meu hino. A única coisa que eu podia tomar uma providência, é se alguém tivesse exibindo o hino pra ganhar dinheiro, enfim, ou então indevidamente né, de outra forma, que nem um que colocou um hino na Internet... dizendo até que o hino era dele ... e nós entramos em contato com YouTube e pedimos para que fosse retirado... aí os caras tiraram... mas... é muito desgastante, então eu preferi colocar nas mãos de Deus, seja feito conforme o que ele quer... porque se tu pega o hino tão bonito, tão sério e vai fazer coisas que não deve com esse hino, então tu vai ter que prestar contas um dia do que tu fizer, então resolvi realmente deixar dessa forma.

Conforme foi relatado, constata-se que o CEDPM, até o momento, também não "patenteou" o seu conjunto de cânticos. Da fala do entrevistado, é possível identificar alguns pontos importantes em torno desta problemática. Observa-se que existe por parte destes Centros a consciência da vulnerabilidade deste patrimônio cultural. Há em contrapartida um esforço para protegê-lo, que pode ser reconhecido, por exemplo, quando vi que durante os rituais da Barquinha, constantemente, se é dado avisos de que

${ }^{44} \mathrm{Na}$ época, em que entrei em contato com Francisco Hipólito, estávamos no meio da pandemia do Covid-19 que estava assolando o planeta. Provavelmente, este fato reforçou sua "indisposição" em conversar comigo naquele momento. Contudo, consegui acesso a informações e alguns documentos referentes ao CECOCJFL por meio da bibliografia consultada. 
é proibida a realização de gravações dos trabalhos espirituais. Contudo, mesmo não sendo permitidas as gravações "clandestinas" dos rituais, o atual desenvolvimento tecnológico as tornaram uma possível realidade, assim como, consequentemente, seu uso de modo indevido, ou seja, em qualquer situação fora do contexto litúrgico da Barquinha.

O assunto da proteção deste patrimônio musical é um assunto complexo para os membros da Barquinha. Além da dificuldade burocrática, apontada por Antônio Geraldo Filho, a qual percebe-se que de fato é um assunto complexo no contexto destes grupos sociais (SANDRONI, 2007), um outro problema a ser superado seria a questão dos conflitos existentes quando o assunto é a quem pertenceria de fato o conjunto dos cânticos que foram e continuam sendo recebidos na Barquinha.

\subsubsection{Alguns pontos de vistas sobre: Livro Azul, hinário e "donos" dos hinos}

Como foi visto no primeiro capítulo, antes de fundar sua doutrina religiosa, Mestre Daniel teria tido experiências místicas nas quais recebia um "Livro Azul". No início desta pesquisa, em princípio, tinha a impressão de que o Livro Azul representaria todo o conjunto dos cânticos recebidos pelos médiuns da missão de Mestre Daniel. Entretanto, durante a investigação, consultando a bibliografia existente e entrevistando os membros da Barquinha, vi que existiam pontos de vistas divergentes em torno do tema. Em campo, busquei entender a partir das informações coletadas o que seria o "Livro Azul". Por meio da bibliografia consultada, consegui obter algumas declarações de Francisco Hipólito de Araújo Neto (CECOCJFL) concernentes ao tema abordado aqui. Numa entrevista concedida a Eloy dos Santos Magalhães (2013), Francisco diz que:

(...) Então o Livro azul é basicamente o hinário e toda a organização da doutrina que Mestre Daniel recebeu. O Hinário do mestre Daniel é por onde vem a doutrina. É o principal elemento do trabalho do Mestre Daniel é o Hinário. (p. 83)

(...) E o hinário dessa casa é um pouco diferente das concepções que se tem nas outras igrejas de Daime. O Hinário dessa casa aqui ele diz que ele recebe da divindade, recebe dos espíritos de luz, e cada hino tem um dono. E cada hino daquele quem trouxe para ele foi uma entidade de luz. (...) Nós dizemos que todos os hinos que foram recebidos nessa casa são do Mestre Daniel. Todos para nós são do Mestre Daniel mesmo que os que o seu Antônio Geraldo recebeu, foi dentro da doutrina do Mestre Daniel, aqui nesta Casa, com a permissão do Mestre Daniel. Ele deixou uma sequência, ele deixou a 
possibilidade dos seus sucessores receberem também hinos. Então nós consideramos que o Hinário é todo dele. O Hinário da Casa de Jesus (CECOCJFL) é uma prerrogativa do Mestre Daniel de abrir as portas desta Casa, fazer por onde nesta Casa se receba a conexão divina, para nós recebermos através da nossa mediunidade, da nossa sensibilidade, já receber a letra e a melodia. Então nós consideramos que todo o Hinário... não tem aqui Hinário do Mestre Daniel, Hinário do seu Antônio Geraldo, Hinário da Dona Chica, Hinário do Seu Manoel Araújo. A gente considera que é um Hinário só: o da Casa de Jesus (CECOCJFL). Meu pai dizia que esse Hinário é indivisível. Esse Hinário não pode ter uma parte aqui e outra para acolá. Ele está num conjunto só. Ele está inclusive num livro só. São as novas páginas do mesmo livro que estão se abrindo a cada dia. (p. 86) (Grifo nosso)

Segundo a minha interpretação, em alguns momentos, a fala do representante do CECOCJFL deixa a entender que o Livro Azul representaria o Hinário do seu Centro, no qual estariam contidos todos os hinos que foram recebidos pelos membros da Casa. Por outro lado, em entrevista, João Batista (CEOCPE) relatou-me que para ele o Livro Azul seria o:

(...) Hinário do Mestre Daniel... quando eu falo de Livro Azul eu me refiro aos ensinamentos que ele recebeu através dos hinos que nós utilizamos na missão. É o Livro Azul, é o livro que ele recebeu com seu Hinário né, aonde ele traz o fundamento da sua missão desde o princípio, o meio e o fim. Esse daí é o Livro Azul no meu entendimento. (...) Existe também os hinos... que ele trouxe depois que ele fez a sua passagem (após o seu falecimento), que são os hinos que diversos irmãos receberam né, inclusive eu também já recebi vários dele, mas, no meu entender... esses hinos... eles são do Hinário de cada irmão... não é... do Livro Azul que é o seu Hinário (Mestre Daniel) (...) Meu Hinário é um... ele faz parte também... desse conjunto de hinos que vieram para missão né, através dos Hinários... da minha mãe, do Mestre Antônio Geraldo, por exemplo. (...) no próprio hino do prestamento de contas né, Frei Daniel... ele fala... lá sobre uma mesa de cristal vi 12 Livros Azuis da cor do céu, entendeu? Então eu acredito, no meu entender... eu já até refletir sobre isso várias vezes, e até mesmo nos trabalhos com o daime também... é que, esses 12 livros são... os livros que complementam o Livro Azul principal que é o livro dele (...) é como se fosse uma coletânea de livros ... de Hinários titulados com esse nome: Livro Azul (...). (Grifo nosso) 
HINO: CASTELO AZULADO N. ${ }^{\circ} 031$

1

A Rainha me levou lá no astral

No Castelo do Monte Azulado

Lá ela mostrou-me as chaves dos mistérios

Das portas dos reinos encantados.

2

Lá a Rainha levou-me num salão

De infindos mistérios de luz

Aonde só se ouve os cânticos dos anjinhos

Louvando a Deus Pai Jesus.

3

Lá sobre uma mesa de cristal

Vi doze livros azuis da cor do céu

Os livros dão as doze ciências e mistérios

$\mathrm{O}$ maior dos mistérios é Deus.

4

Meus irmãos façam o sinal da santa cruz

E se afirmem na concentração

Que eu estou no astral no Castelo Azulado

Prestando contas desta sessão.

5

Os hinos que eu canto aqui nesta sessão

$\mathrm{Em}$ todos tem o nome de Deus

E tudo que eu afirmo com o seu sagrado nome

Quem tem que prestar contas sou eu.

6

A conta que estou a prestar lá no astral

É para Deus e a Virgem da Conceição

E também estou recebendo os livros das ciências

E mistérios aqui desta sessão.

Foto 32 - Fonte: (MAGALHÃES, 2013)

Acima, coloquei uma foto do hino ao qual o entrevistado faz referência em sua fala. Como se depreende dos relatos colocados acima, Joca (CEOCPE) e Francisco (CECOCJFL) em determinados momentos apresentam pontos de vistas divergentes quando o assunto é o Livro Azul. A fala do membro do CEOCPE, exposta acima, estaria revelando um significado mais profundo sobre o Livro Azul. Significado este que, inclusive, encontra fundamento nas palavras do próprio Mestre Daniel que estão contidas na mensagem do hino "Castelo Azulado" (foto 16). Segundo a minha interpretação, João Batista entende que o Livro Azul de Mestre Daniel seria um livro (Hinário) que agrega outros livros (Hinários) dentro de si, uma espécie de coletânea. 
Algo semelhante ao contexto da Bíblia, ou seja, um livro composto por outros livros. Dona Chica Gabriel, em poucas palavras apresentou um ponto de vista semelhante sobre este tema: “Acredito que o Livro Azul é um fundamento na Missão... os Livros do Livro Azul, como diz, né... tem um fundamento... muito grande."

Baseado nas declarações de Francisco Hipólito, Eloy dos Santos dos Magalhães (2013) sustenta o seguinte ponto de vista acerca do tema abordado aqui:

Ao receber e abrir o Livro Azul "invisível", enfim, resultando na construção do Livro Azul "visível", o Hinário, Daniel indicará que esse fluxo criativo qualifica a especificidade de sua Missão. Portanto, a passagem de Mestre Daniel não justificou o fechamento do repertório de seu Hinário, pelo contrário, permaneceria aberto. Os sucedâneos de Daniel na "abertura inspirada" do Livro Azul foram os presidentes que sobrevieram, respectivamente, os senhores Antônio Geraldo da Silva e Manuel Hipólito de Araújo. Além deles, a senhora Francisca Campos do Nascimento (Chica Gabriel), também atuou no recebimento dos hinos. (p. 87-88, grifo nosso)

Para o autor, após o falecimento de Mestre Daniel, os seus sucedâneos teriam continuado a receber os hinos, entretanto, ao que consta, ele considera que Dona Chica Gabriel atuou, recebendo hinos após o desencarne do seu Mestre, o que não mais ocorreria atualmente. Sob esse ponto de vista, talvez, Eloy e Francisco considerem que os vários hinos que Mestre Antônio Geraldo da Silva e Dona Chica Gabriel receberam após se desligarem do CECOCJFL não façam parte do Livro Azul de Mestre Daniel, tampouco os hinos que os demais sucedâneos estariam recebendo nos outros Centros da Barquinha.

Até aqui, creio que para o leitor, é possível ter-se uma noção do quanto é complexa a questão relativa aos direitos autorais dos cânticos que são recebidos pelos médiuns da Missão de Mestre Daniel. Este cenário atual, que dificulta sensivelmente uma eventual tentativa de se construir um consenso em prol da proteção deste patrimônio musical (“O Livro Azul”), tem origem num passado turbulento da história da Barquinha. No primeiro capítulo, vimos que a primeira comunidade institucionalizada após o falecimento de Daniel Pereira de Mattos foi o Centro Espírita e Culto de Oração Casa de Jesus Fonte de Luz (CECOCJFL). Seus conflitos internos desencadeariam a saída de vários membros ao longo dos anos. Foi o caso de Mestre Antônio Geraldo, que saiu em 1977, fundando em 1979, o Centro Espírita Daniel Pereira de Mattos (CEDPM), e o de Dona Chica Gabriel, que se desligou em 1991, fundando, em seguida, o Centro Espírita Obras de Caridade Príncipe Espadarte (CEOCPE) no mesmo ano. Os dois personagens aqui citados desta historia teriam 
recebido espiritualmente vários hinos ao longo dos anos em que cumpriram seus compromissos religiosos no CECOCJFL. Entretanto, conforme as informações obtidas em campo, ao se afastarem do referido Centro, ambos não tiveram acesso à obra completa referente aos hinos antigos da missão de Mestre Daniel. Deixando para trás, inclusive, alguns dos próprios hinos que receberam na Casa.

\section{Considerações Finais}

Ao longo do texto, expus os dados coletados e as reflexões produzidas por meio desta investigação. Seguindo os pressupostos de Anthony Seeger (2004), em campo, foi realizada uma etnografia da música da Barquinha, a qual nos possibilitou contemplar esta tradição musical-religiosa pelo viés musicológico.

Foram identificadas algumas funções da música dentro do contexto estudado. Primeiramente, observei que ela pode influenciar sensivelmente o processo de vinculação entre os indivíduos e a Barquinha. Isto fica claro nos relatos obtidos e na própria experiência campal que indicaram duas evidências disto: por conta do poder de encantamento inerente a esta arte, a música atuaria como um grande atrativo para os neófitos; além disso, ela é uma ferramenta que mexe com as emoções do ouvinte amplificando as experiências místicas dos indivíduos da Barquinha durante os trabalhos espirituais com a ayahuasca. A segunda função percebida é referente à influência da música no processo de formatação da ritualística e da cosmologia de cada comunidade da missão de Mestre Daniel. Isto foi percebido quando os relatos dos entrevistados revelaram que o hinário está em constante transformação. Ao longo dos tempos, os médiuns estariam recebendo novos salmos que podem suscitar tanto a implementação de outras atividades religiosas que vão sendo incluídas na rotina de trabalhos de cada comunidade, como novidades no conjunto doutrinal, revelações espirituais e etc.. Por último, foi constatado que os hinos, salmos, benditos e pontos têm uma função estritamente litúrgica no contexto da Barquinha, de modo que, cada atividade religiosa possui seus respectivos cânticos, por meio dos quais estes rituais se desenrolam.

A análise musical foi um desafio à parte dentro deste trabalho de pesquisa. Os métodos analíticos convencionais, consagrados no universo da música de tradição erudita, aparentam não ser adequados o suficiente quando o assunto é a análise de culturas musicais de tradição oral. Diante disto, resolvemos ir a campo seguindo os pressupostos sugeridos por Anthony Seeger, analisando as performances musicais, 
buscando não desvincular música, performers e audiência do contexto aos quais estão inseridos (SEEGER, 2004).

Quando o assunto é gênero, a música da Barquinha pode ser classificada como música vocal, religiosa, cristã, que atende às liturgias das igrejas ligadas à missão de Mestre Daniel. Além disso, nesta investigação considerei conveniente enquadrá-la num gênero musical, de certo modo, ainda não "oficialmente convencionado", ao menos no contexto acadêmico, a "música brasileira de ayahuasca" (LABATE e PACHECO, 2009). Penso que os fazeres musicais que afloram no seio das religiões ayahuasqueiras possuem elementos em comum, suficientes para a designação do referido gênero citado acima.

A investigação revelou que a Barquinha é uma tradição religiosa bastante sincrética. Em campo, notei que cada Centro desenvolve sua própria cosmologia, cada qual estabelece uma identidade diferenciada. Isto pode explicar a variedade de estilos musicais que vem se estabelecendo em cada grupo. Um exemplo claro disto, é a influência que a Umbanda exerce no CEOCPE que se revela nos ritmos adotados nos rituais festivos (nagô, congo de ouro, samba de cabula, ijêxá e etc.), assim como na instrumentação (atabaques, djembê, caxixi, agogô e etc.).

Como foi visto, cada Centro da Barquinha constituiu e vem constituindo o seu próprio conjunto de cânticos, na medida em que os médiuns de cada Igreja vão recebendo mais hinos, salmos, benditos e pontos que vão compondo cada repertório local. No geral, as composições são compostas pelos tradicionais materiais sonoros, escalas naturais e arpejos de tríades maiores e menores. Em alguns hinos, nota-se também o uso da escala harmônica menor. No tocante ao acompanhamento rítmicoharmônico, cada igreja apresenta estilos e características próprias. Em todos os Centros observados, a harmonia tonal/tradicional é o vocabulário harmônico predominante desta música.

O repertório musical dos Centros da Barquinha é constituído por composições que seriam recebidas espiritualmente. Segundo a literatura espírita, a música mediúnica se realiza por meio de pessoas que executam ou compõem obras musicais sob a influência dos Espíritos (NASCIMENTO, 2014). Mas a quem poderíamos atribuir a autoria destes cânticos? Analisando o fenômeno, percebi que, no geral, existem dois modos de recebimento de hinos. Na primeira modalidade, ao que tudo indica, o médium que recebe a canção é o interlocutor de sua narrativa. Nesta situação, não fica claro 
quem "assina" a obra musical. Na segunda modalidade, a interlocução da mensagem fica a cargo da entidade que "traz" o salmo. Neste caso, considerei que a autoria da composição pode ser atribuída ao espírito que estaria transmitindo estas comunicações aos respectivos médiuns.

Com relação à questão referente aos direitos autorais dos hinos, vislumbro alguns problemas práticos que refletem a complexidade do tema e que, do meu ponto de vista, precisariam ser debatidos entre os membros destas comunidades, na busca de uma metodologia adequada para proteger este patrimônio cultural musical. O primeiro ponto seria definir: o que deve ser registrado, cada cântico em si? O conjunto dos cânticos de cada Centro? Ou: o conjunto dos cânticos da Missão de Mestre Daniel como um todo? Dentre as três opções citadas, cada uma possivelmente desencadearia outra série de questões que careceriam de debates e consenso entre os grupos. Por exemplo, se por um acaso, o consenso apontasse para o registro de cada cântico em si, seria preciso definir: a quem seria atribuída a propriedade do cântico, ao médium que a recebeu, ou ao Centro ao qual ele é vinculado? Por outro lado, se por ventura o coletivo decidisse que o que deveria ser registrado é o conjunto dos cânticos de cada Centro, neste caso, seria preciso debater, por exemplo: como ficaria a questão dos hinos antigos que foram recebidos por alguns membros da primeira comunidade que se formou e que hoje estão vinculados a outros Centros?

Neste debate aqui fomentado por estas reflexões, dentre as opções indicadas acima, talvez, o caminho menos complexo, e que geraria menos problemas, seria o registro do conjunto dos cânticos da Missão de Mestre Daniel como um todo. Inclusive, penso que deste modo, seria mais prático viabilizar o tombamento desta cultura musical como patrimônio imaterial brasileiro. Obviamente, mesmo assim seria preciso definir através do diálogo entre os Centros, o que seria de fato este conjunto completo relativo aos cânticos que os médiuns estariam recebendo ao longo dos anos, ou seja, se faria necessário demarcar as fronteiras desta tradição religiosa que hoje conhecemos como "Barquinha".

Segundo o meu entendimento, falar em proteger o conjunto dos cânticos recebidos na Barquinha é um assunto complexo que necessariamente exige uma metodologia que deve ser construída democraticamente, por meio do amplo debate entre todos os envolvidos no contexto, ou seja, todos os médiuns que receberam os hinos, além daqueles que herdariam, de alguma forma, os direitos à propriedade 
patrimonial desta cultura musical e, quando falo assim, estou me referindo, principalmente aos membros das comunidades que foram constituídas pelos médiuns em questão.

O problema é que atualmente na Barquinha não existe um consenso em torno da questão da autoria dos hinos recebidos. Além disso, em campo, não foi possível identificar a existência deste amplo debate (diálogo) entre os Centros, abordando tal questão. Constatei que até o momento o que existe são vários pontos de vistas individuais, muitas vezes conflitantes, e uma provável ação unilateral de um dos Centros que até ao término desta investigação, não foi devidamente confirmada.

Gostaria de finalizar este trabalho com uma reflexão. Durante a investigação, percebi que algumas questões que inevitavelmente interpenetram-se no universo cosmológico da Barquinha, muitas vezes, se tornam questões geradoras de conflitos na comunidade. Em comparação com outros contextos religiosos mais antigos, a Barquinha é uma tradição recente, jovem, com aproximadamente 75 anos de existência. $\mathrm{Na}$ história da religião católica, por exemplo, podemos perceber que muitas de suas crenças e dogmas de fé são o resultado de anos, às vezes, séculos de debates entre os seus correligionários. Inclusive, como se vê, a eclética doutrina religiosa da Barquinha agregou em sua cosmologia muitos destes temas que, no passado, foram objetos de intensas discussões, assembleias, concílios e etc., que culminaram em consensos que hoje alimentam a fé de inúmeras pessoas. Um exemplo disto é o dogma da imaculada Conceição da Virgem Maria, a mãe de Jesus, tão venerada e cantada, tão presente nas mensagens dos hinos da Barquinha (a Virgem Mãe Imaculada Conceição, ou simplesmente a Virgem Mãe da Conceição).

Penso que, dentro de um contexto comunitário-religioso, as questões que vão surgindo ao longo do tempo, carecem de amplos debates. Em termos filosóficos, na busca do ideal e da verdade, opiniões diferentes em torno de um tema não seriam de todo ruim. O problema maior é o egoísmo humano, a falta do diálogo respeitoso e a ausência de um firme propósito de se construir fraternalmente um consenso coletivo por meio do debate de ideias.

E para finalizar com música, deixo aqui um hino recebido por Dona Chica Gabriel que é cantado nas romarias de alguns Centros da Barquinha. 


\section{Sinal de Paz}

Foxtrot

A

Recebido por Francisca Campos do Nascimento (Chica Gabriel)
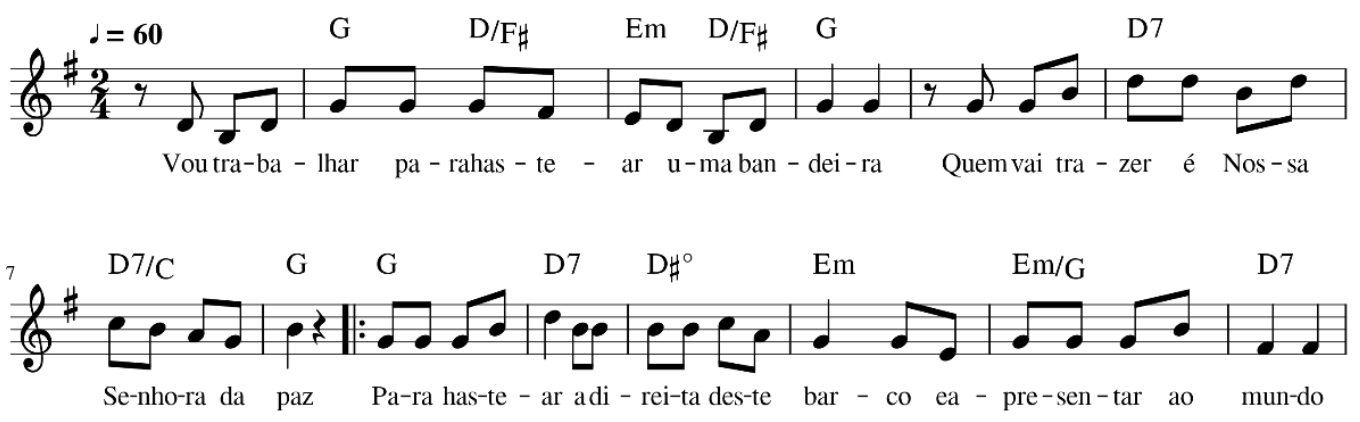

B
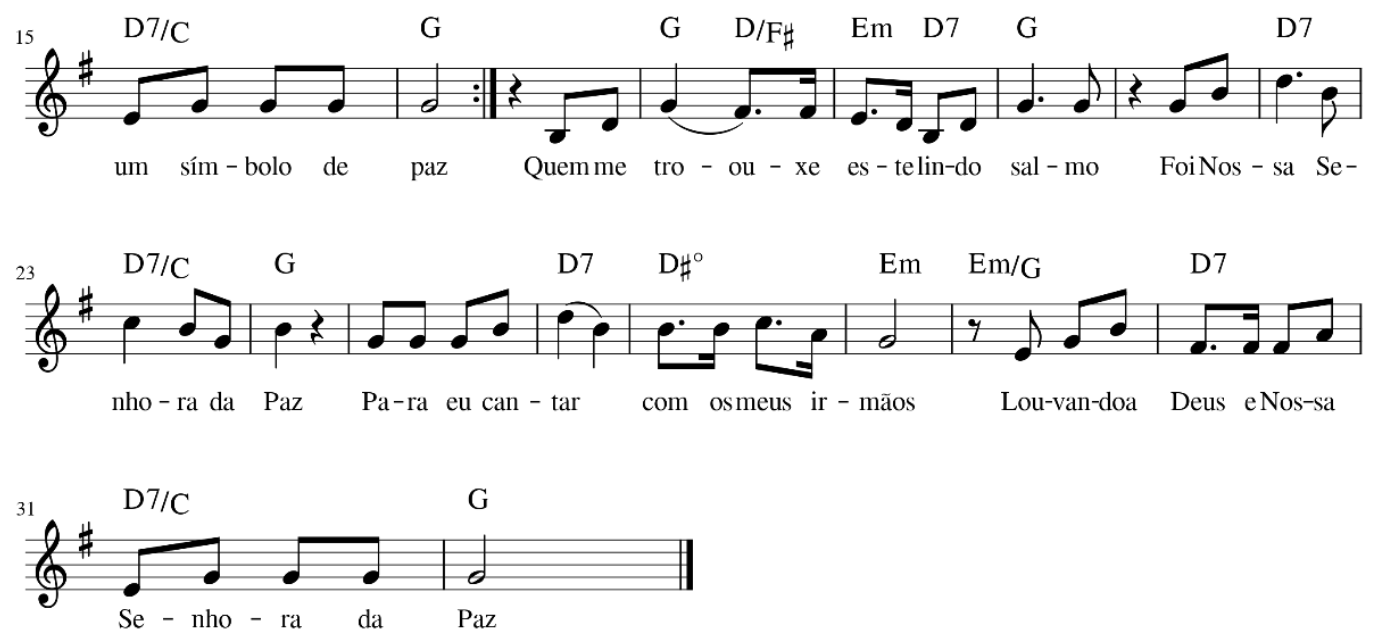

(Partitura 34)

Vou trabalhar para hastear uma bandeira

Quem vai trazer é Nossa Senhora da Paz

Para eu hastear à direita deste barco

E apresentar ao mundo um símbolo de paz $\}$ Bis

Quem me trouxe este lindo salmo

Foi Nossa Senhora da Paz

Para eu cantar com os meus irmãos

Refrão

Louvando a Deus e a Nossa Senhora da Paz

Nesta bandeira estão escritas

Cinco lindas iniciais

E tem cinco lindas estrelas

E ainda está escrita Salve a Senhora da Paz $\}$

Bis

As iniciais que na bandeira estão escritas

São os mistérios de Nossa Senhora da Paz

Para seguirmos todos unidos

Em uma só igualdade e emanação de paz $\}$

Bis 
As iniciais que na bandeira estão escritas

Estão anunciando a volta do Pai

Para nós seguirmos todos unidos

Com firmeza em Nossa Senhora da Paz

Bis

Ela é quem segue a nossa frente

Pedindo a Jesus, para o mundo a paz

Para livrar todos os filhos

Das tentações e das artes de Satanás

Bis

Agora vamos todos rezar com firmeza

Contritos com Nossa Senhora da Paz

$\left.\begin{array}{c}\text { Para hastear esta bandeira } \\ \text { E dar lindos louvores a Nossa Senhora da Paz }\end{array}\right\}$

$\mathrm{Bis}$

Eu agradeço ao meu Bom Jesus

E a Nossa Senhora da Paz

Por eu ter recebido num Domingo de Ramos

Este lindo salmo que é um sinal de paz

Bis 


\section{Referências Bibliográficas}

ABRAMOVITZ, Rodrigo Sebastian de Moraes. Música e Miração: Uma Análise Etnomusicológica dos Hinos do Santo Daime. Dissertação (Música) - Universidade do Rio de Janeiro, 2003.

AGAWU, Kofi. "Analyzing Music Under the New Musicological Regime." Music Theory Online 2, no. 4, 1996.

ANTUNES, José Paulo. Debates e clivagens em torno da noção de Música Sacra no catolicismo contemporâneo, publicado na revista Portuguesa da Ciência das Religiões Ano II, 2003, n. ${ }^{\circ}$ 3/4 - 83-92.

ARAÚJO NETO, Francisco Hipólito et al. 2010. No caminho de Mestre Daniel. Rio Branco: Ministério da Cultura/Fundação Garibaldi Brasil.

ARAÚJO, Wladimyr S. Navegando nas Ondas do Daime: história, cosmologia e ritual na Barquinha. Campinas: Editora da Unicamp,1999.

BEARD, David \& GLOAG, Kenneth. Musicology: The key concepts. London. Routledge, 2005.

BRISSAC, Sérgio. A Estrela do Norte Iluminado até o Sul: uma etnografia da Uniaõ do Vegetal em um contexto urbano. Dissertação de Mestrado em Antropologia, Rio de Janeiro, UFRJ-Museu Nacional, Programa de Pós-Graduação em Antropologia Social, 1999.

BROWN, R. (1971). Unfinished Symphonies. London: Souvenir Press.

BURROWS, Edwin G. Native music of the Tuamotus. Honolulu: Bernice P. Bishop Museum. 1933.

CASCUDO, Luís da Câmara. Dicionário do Folclore Brasileiro. 11. ed. ilustrada. São Paulo: Global, 2002.

CEMIN, Arneide Bandeira. Ordem, xamanismo e dádiva: o poder do santo Daime. Tese de Doutorado em Antropologia Social, USP- Departamento de Antropologia, 1998.

CORRÊA, Antenor Ferreira. O sentido da análise musical, publicado na revista Opus, v. 12, p. 33-53, 2006.

COPLAND, Aaron. Como ouvir e entender música. Rio de Janeiro: Artenova, 1974.

COSTA, Cristiane A. Uma casa de "preto-velho" para "marinheiros" cariocas: a religiosidade em adeptos da Barquinha da Madrinha Chica no estado do Rio de Janeiro. Dissertação de Mestrado. Campina Grande: UFPB, 2008.

DIAS JR., Walter. O Império de Juramidam nas Batalhas do Astral: uma cartografia do imaginário no culto do Santo Daime. Tese de Mestrado em Antropologia, PUC-SP, 1992. 
FAOUR, Paula. Acompanhamento Pianístico em Bossa Nova: Análise Rítmica em Duas Performances de João Donato e Cesar Camargo Mariano. Dissertação de Mestrado em Música, Unirio, 2006.

FRENOPOULO, Christian. Healing Performances in the Barquinha religion: The tropes of exorcisms, passes and pontos riscados. Paper presented at the Society for the Anthropology of Religion 2005 Meeting. Vancouver, 2005.

FRÓES, Vera. Historia do Povo de Juramidam: A cultura do Santo Daime. Manaus: Suframa, 1986.

GOULART, Sandra L. As Raízes Culturais do Santo Daime. Dissertação de Mestrado em Antropologia Social, FFLCH-USP, 1996.

GOULART, Sandra L. Contrastes e Continuidades em uma Tradição Amazônica: as religiões da ayahuasca. Tese de Doutorado em Antropologia Social, Unicamp, 2004.

GROISMAN, Alberto. Eu venho da floresta: um estudo sobre o contexto simbólico do uso do Santo Daime. Florianópolis: Editora UFSC, 1999.

KERMAN, Joseph. Musicologia. SP: Martins Fontes, 1987.

LABATE, Beatriz Caiuby. A Reinvenção do uso da ayahuasca nos centros urbanos. Campinas, Dissertação de Mestrado em Antropologia Social. IFCH-Unicamp, 2000, pp. 178-190.

LABATE, Beatriz C. e SENA ARAÚJO, Wladimyr (orgs.). O Uso ritual da ayahuasca. Campinas, Ed. Mercado de Letras, 2002.

LABATE, Beatriz C. e PACHECO Gustavo. "As Matrizes Maranhenses do Santo Daime", in: LABATE, Beatriz C. e SENA ARAÚJO, W. (orgs.). O Uso ritual da ayahuasca. Campinas, Ed. Mercado de Letras, $2^{\mathrm{a}}$ ed., 2004.

LABATE, Beatriz Caiuby e PACHECO, Gustavo. Música Brasileira de Ayahuasca / Beatriz Caiuby Labate, Gustavo Pacheco. Campinas, SP: Mercado de Letras, 2009.

LA RUE, Jan. Análisis Del Estilo Musical: pautas sobre la contribución a la música del sonido, la armonía, la melodía, el ritmo y el crecimiento formal. Barcelona: Editorial Labor S.A. 1989.

MACRAE, Edward. Guiado pela Lua. Xamanismo e uso ritual da ayahuasca no culto do e uso ritual da ayahuasca no culto do Santo Daime. São Paulo: Brasiliense, 1992.

MAGALHÃES, E. S. Balanços de Luz: devoção e experiência a bordo do Barquinho Santa Cruz. Tese (Doutorado em Ciências Sociais) - Universidade Federal de Campina Grande. Campina Grande, Paraíba, 2013.

MARGARIDO, S. \& ARAÚJO NETO, F. 2005. Mestre Daniel: história com a Ayahuasca. Rio Branco: Fundação Garibaldi Brasil.

MERCANTE, Marcelo S. Imagens de cura: Ayahuasca, imaginação, saúde e doença na Barquinha. - Rio de Janeiro Editora: FIOCRUZ, 2012. 
MERRIAM, Alan P. Anthropology of Music. Evanston: Northwestern University Press, 1964. 358p.

MOURA, Marta Antunes de Oliveira (Org), 1946 - Mediunidade: estudo e prática. Programa 1. 2. ed. - 1. imp. — Brasília: FEB, 2014.

NETTL, Bruno. The Study of Ethnomusicology: thirty-one Issues and Concepts. University of Illinois Press, Chicago, 2005.

OLIVEIRA, Rosana Martins de. De folha e cipó é a Capelinha de São Francisco: a religiosidade popular na cidade de Rio Branco - Acre (1945-1958). Dissertação de mestrado, Recife: UFAC/UFPE, 2002.

PASKOALI, V. P. A cura enquanto processo identitário na Barquinha: o sagrado no cotidiano. Dissertação (Mestrado em Ciências Sociais) - Pontifícia Universidade Católica de São Paulo. São Paulo, 2002.

PIEDADE, Acácio Tadeu de C.. A Etnografia da Música segundo Anthony Seeger: clareza epistemológica e integração das perspectivas musicológicas, publicado na revista cadernos de campo, São Paulo, n. 17, p. 233-235, 2008.

REHEN, Lucas Fonseca KASTRUP. "Receber não é compor: Música e emoção na religião do Santo Daime”. Relig. Soc. v.27, no.2, Rio de Janeiro, 2007.

RODRIGUES, Danielle. Mistérios e encantos da Oaska: Danielle Rodrigues entrevista o Mestre da União do Vegetal. Campinas, SAMA Ed., 1998.

SANDRONI, Carlos. Propriedade Intelectual E Música De Tradição Oral, publicado na revista Cultura e Pensamento, 3, dezembro de 2007, p.65-80.

SANTOS, Ricardo Assarice dos. A híbrida Barquinha: Uma revisão da história, das principais influências religiosas e dos rituais fundamentais. Dissertação (Mestrado em Ciências da Religião) - Pontifícia Universidade Católica de São Paulo. São Paulo, 2017.

SILVEIRA, Alleton de Melo. Música sacra, conceitos e terminologias. In: SIMPÓSIO INTERNACIONAL FILOSOFIA - TEOLOGIA \& CIÊNCIAS DA RELIGIÃO, XIV, 2018, Minas Gerais.

SEEGER, Anthony. Etnografia da Música. (Sinais Diacrônicos: música, sons e significados). S. Paulo: USP (Soma - Grupo de Pesquisa de Som e Música em Antropologia - FFLCH - Dep. Antropologia), 2004.

WILLIN, Melvyn J.. Paramusicology: An investigation of music and paranormal phenomen., Ph.D (Musicology) - University of Sheffield, 1999. 